\title{
PUBLIC POLICY AND IDEATION
}

\section{A CASE OF A GREY-ZONE COUNTRY - PAKISTAN}

A Dissertation Submitted in Fulfilment of the Requirements for the PhD Degree in International Development Studies to the Institute for Development Research and Development Policy (IEE), Ruhr University of Bochum

\author{
By: \\ Atif Ikram Butt \\ Supervised by: \\ Professorin Dr. Marianne Kneuer \\ Prof. em. Dr. Uwe Andersen
}

July 2017 
(2) 


\section{LIST OF CONTENTS}

$\begin{array}{cr}\text { I Abstract } & \text { vii } \\ \text { II Preface } & \text { viii } \\ \text { III Declaration } & \mathrm{xv} \\ \text { IV Acknowledgment } & \mathrm{xvi} \\ \text { V List of Tables and Figures } & \mathrm{xviii} \\ \text { VI Glossary of Key Concepts } & \mathrm{xxi} \\ \text { VII List of Acronyms and Abbreviations } & \text { xxiii }\end{array}$

\section{Chapter 1 About this Research}

1.1 Introduction 1

1.2 A Brief History of Public Policy 2

1.3 Defining Public Policy 5

1.4 Theorising Public Policy $\quad 8$

$\begin{array}{lll}1.5 & \text { The Plan of this Thesis } & 14\end{array}$

$\begin{array}{ll}1.6 \text { Concluding Words } & 18\end{array}$

Chapter 2 Theories of Regulation and Regime Type

$\begin{array}{ll}2.1 & \text { Introduction }\end{array}$

2.2 Political Grey-Zone 22

$\begin{array}{lll}2.3 & \text { Key Considerations } & 24\end{array}$

2.4 Economic Theories of Regulation $\quad 29$

$\begin{array}{lll}2.4 .1 & \text { Public Interest Theory }\end{array}$

$\begin{array}{lll}\text { 2.4.2 Private Interest Theory } & 33\end{array}$

$\begin{array}{lll}2.5 & \text { Social Regulation and Deregulation Movements } & 37\end{array}$

2.6 Reformulation of Economic Theories of Regulation 42

2.6.1 From Private to Interest Group-Theories 42 
2.7 A Developing Agenda 53

$\begin{array}{lll}2.8 & \text { Concluding Words } & 60\end{array}$

\section{Chapter 3 Ideational Institutionalism and Policymaking}

$\begin{array}{lll}3.1 & \text { Introduction } & 63\end{array}$

3.2 Institutions as Actors $\quad 64$

3.2.1 The Three Established New Institutionalisms 66

$\begin{array}{lll}\text { 3.2.2 } & \text { Role of Ideas in New Institutionalism } & 69\end{array}$

3.2.3 Ideas as 'Policy Logs'

$\begin{array}{lll}\text { 3.2.4 Ideational Institutionalism } & 76\end{array}$

3.3 A Typology of Ideas $\quad 83$

$\begin{array}{ll}3.4 & \text { Concluding Words } \\ \end{array}$

Chapter 4 Ideas and the Methodological Approach of 'Policy as Discourse'

$\begin{array}{lll}4.1 & \text { Introduction } & 103\end{array}$

$\begin{array}{ll}4.2 & \text { Origin of Ideas } \\ \end{array}$

$\begin{array}{lll}\text { 4.3 The Methodological Approach of 'Policy as Discourse' } & 112\end{array}$

$\begin{array}{ll}\text { 4.4 Ideational Framework of Public Policy } & 123\end{array}$

4.5 Developing a Public Policy Theory - Some Methodological Considerations 129

$\begin{array}{lll}4.5 .1 & \text { Temporality } & 131\end{array}$

$\begin{array}{lll}\text { 4.5.2 Predictability } & 132\end{array}$

$\begin{array}{lll}\text { 4.5.3 Multiplicity of Participants } & 132\end{array}$

$\begin{array}{lll}\text { 4.5.4 Interaction } & 134\end{array}$

$\begin{array}{ll}\text { 4.6 Concluding Words } & 135\end{array}$

\section{Chapter 5 Public Policy Making in Pakistan}

$\begin{array}{lll}5.1 & \text { Introduction } & 141\end{array}$

$\begin{array}{lll}\text { 5.2 The Federation of Pakistan } & 142\end{array}$

$\begin{array}{lll}\text { 5.3 The State of Pakistan and its Federating Units } & 144\end{array}$ 
$\begin{array}{lll}\text { 5.4.1 The Legislative Branch } & 150\end{array}$

$\begin{array}{lll}\text { 5.4.2 The Executive Branch } & 154\end{array}$

$\begin{array}{lll}\text { 5.4.3 The Judicial Branch } & 158\end{array}$

$\begin{array}{ll}\text { 5.5 The Process of Public Policy Making in Pakistan } & 160\end{array}$

$\begin{array}{lll}\text { 5.5.1 The Legislature } & 160\end{array}$

$\begin{array}{lll}\text { 5.5.2 The Executive } & 165\end{array}$

$\begin{array}{lll}\text { 5.5.3 The Judiciary } & 167\end{array}$

5.6 Legislative Public Policies under the Thirteenth National Assembly of Pakistan 169

$\begin{array}{ll}5.7 \text { Concluding Words } & 171\end{array}$

\section{Chapter 6 Contestation and Inclusiveness in Public Policy Making in Pakistan}

$\begin{array}{llr}6.1 & \text { Introduction } & 183\end{array}$

$\begin{array}{ll}\text { 6.2 Interest Groups and Theories of the State } & 185\end{array}$

$\begin{array}{lll}\text { 6.3 Interest Groups Intermediation and State-Centred Theories } & 188\end{array}$

$\begin{array}{ll}\text { 6.4 The Case of Pakistan } & 193\end{array}$

$\begin{array}{lll}\text { 6.4.1 Pakistan - A Struggling Democracy } & 193\end{array}$

6.4.2 Roots of Elitism in Pakistan 193

6.4.3 Interests Groups in Pakistan and their Rising Influence 198

$\begin{array}{ll}\text { 6.5 Concluding Words } & 210\end{array}$

\section{Chapter 7 Research Methodology and Design}

$\begin{array}{lll}7.1 & \text { Introduction } & 213\end{array}$

$\begin{array}{lll}7.2 & \text { Case Study Approach } & 214\end{array}$

$\begin{array}{lll}7.3 & \text { The Study Area } & 215\end{array}$

$\begin{array}{lll}7.4 & \text { Research Framework } & 219\end{array}$

$\begin{array}{ll}\text { 7.5 Sampling and Sample Size } & 220\end{array}$

$\begin{array}{ll}\text { 7.6 Unit of Analysis } & 221\end{array}$

$\begin{array}{lll}7.7 & \text { Sources of Information } & 222\end{array}$ 
7.8 Collection of Data, Recording and Documentation 224

$\begin{array}{lll}7.9 & \text { Study Tool } & 224\end{array}$

$\begin{array}{ll}\text { 7.10 Analysis of Data and Triangulation } & 226\end{array}$

$\begin{array}{lll}7.11 & \text { Limitations of the Study } & 227\end{array}$

$\begin{array}{ll}7.12 & \text { Concluding Words } \\ & 229\end{array}$

Chapter 8 Ideational Institutionalism and Public Policy Making in Pakistan

$\begin{array}{lll}8.1 & \text { Introduction } & 233\end{array}$

8.2 The Protection Against Harassment of Women at the Workplace Act, $2010 \quad 235$

8.2.1 Ideational Forces Behind Legislation Against Sexual Harassment of 239 Women at the Workplace

8.2.2 Underlying Ideational Dimensions to the Legislation on Sexual 253 Harassment

8.3 The Transplantation of Human Organs and Tissues Act, 2009

8.3.1 Ideational Forces Behind Organ Transplantation Law in Pakistan 268

8.3.2 Underlying Ideational Dimensions to the Organ Transplantation Law in 278 Pakistan

8.4 The Right to Free and Compulsory Education Act, 2012

8.4.1 Ideational Forces Behind the Right to Free and Compulsory Education 298 Act in Pakistan

8.4.2 Underlying Ideational Dimensions to Free and Compulsory Education $\quad 311$ Act in Pakistan

$\begin{array}{lll}8.5 & \text { Ideational Policymaking in Pakistan } & 324\end{array}$

$\begin{array}{ll}\text { 8.6 Concluding Words } & 332\end{array}$

\section{Chapter 9 Towards a New Policy Making Paradigm of Ideas}

$\begin{array}{lll}9.1 & \text { Introduction } & 343\end{array}$

$\begin{array}{lll}9.2 & \text { Agenda for Future Research } & 344\end{array}$

9.3 Typologies of Public Policy 348 
9.4 A Typology Based on the Origin of Public Policy

9.5 Concluding Words

Annexures

1 Study Tools

$\begin{array}{lll}1.1 & \text { Discussion Guidelines - Providers } & 357\end{array}$

$\begin{array}{lll}1.2 & \text { Discussion Guidelines - Supporters } & 360\end{array}$

1.3 Discussion Guidelines - Controllers 363

2 Bibliography 367

3 Curriculum Vita 391 


\section{ABSTRACT}

Study of public policy is incomplete without the consideration of the context in which the policy decisions are made. Surprisingly, there is hardly anything substantial contributed towards building a theory of public policy for developing countries. By taking the case of Pakistan, as one of the grey-zone countries, the research sets the objective of filling-in this theoretical gap through analysis of social-sector policymaking. The research employs the analytical construct of ideational institutionalism, which offers the flexibility of contextspecific examination of public policy making. With the help of discourse analysis, the research examines basic claims of ideational institutionalism for understanding the mechanism through which ideas originate and affect public policy outcomes. By applying the case study approach, the research substantiates the enormous promise ideational institutionalism holds for studying policymaking process in countries of grey-zone.

Subject Headings: Pakistan, New Institutionalism, Public Policy, Public Policy Analysis, and Political Decision-making 


\section{PREFACE}

As part of the Energy Conservation Plan, Pakistan tried experimenting once more with the daylight saving time (DST) in 2008. The move was aimed at cutting energy cost by taking advantage of longer summer days. It was implemented first in 2002 on an experimental basis but abandoned soon after. This time around, however, it continued into the next year and since then never been tried again. It was a "monumental failure" the first time, writes the editorial of the national daily the Dawn. ${ }^{1}$ An article in another daily, the News, questions whether the government achieved in its plan of saving 400 megawatts of electricity through DST when in 2008 "most of the people, especially those living in rural areas, reportedly paid no heed to it." In an editorial in the daily News, the paper recounts that "Daylight saving time seems to have resulted only in people delaying dining or sleeping times, rather defeating the whole purpose of the exercise. ${ }^{3}$ Another editorial in the daily News dubs the whole experience as "a mere cosmetic measure that has been tried before and has always failed...in the pretence that the government is trying to do something." writes in similar lines, "if the government didn't do anything it would be accused of sitting idle as the energy crunch became more debilitating by the day." Three years later in 2012 at the National Energy Conference, the government conceded the failure of its policy and decided to "no longer be experimenting with daylight savings time and instead simply

\footnotetext{
${ }^{1}$ Editorial, May 16, 2008, the Dawn $<$ http://www.dawn.com/news/1071186 $>$ accessed on September 16,2015

${ }^{2}$ Noor Aftab, "People ask whether target achieved?" The News < http://www.thenews.com.pk/TodaysPrintDetail.aspx?ID=206210\&Cat=6\&dt=11/9/2009> accessed on September 16, 2014

${ }^{3}$ Editorial, "Even less light," June 30, 2008, the News < http://www.thenews.com.pk/TodaysPrintDetail.aspx?ID=121293\&Cat=8\&dt=11/1/2008> accessed on September 16, 2015

${ }^{4}$ Editorial, "The last ray," October 13, 2013, the News $<$ http://www.thenews.com.pk/Todays-News8-208044-The-last-ray>, accessed on September 16, 2015
} 
change summer office timings to save energy." $"$ In a country where majority of the population lives in rural areas, has high illiteracy and low levels of education and outdoor activities in summer mostly taking place after nightfall, such measures were non-starter from the very beginning.

In 2010, the Punjab Assembly passed a resolution unanimously calling for an all-out ban on late-night packages offered by telecommunication companies. These packages offered significantly reduced tariffs as a marketing strategy targeting young customers for increasing network usage during periods of low traffic. The resolutions stated, "Because of such mobile packages ... the young generation, particularly students, remain busy texting and talking over the phone the entire night, without caring for their studies, health and sleep ... these packages ... [are not in line with] social and moral values and customs ... a ban should be imposed on all such packages." ${ }^{\prime 6}$ The resolution recommended, "the federal government that instructions to the mobile companies be issued that they should not promote the tendency of cheap rate late night packages for changing tendencies in society." Murtaza Ali Jafri, writing for the Dawn, asks whether this resolution should be called "politics or parenting." Mocking the resolution he writes, "Forget terrorism, the energy crisis, a weakened government, and water shortages - apparently boys and girls texting and calling each other past their bed time has become a matter of national concern.,"7 A month later the Khyber Pakhtunkhwa Assembly passed a similar resolution and, in addition to late night packages, demanded the ban on text messages bundles as well. The matter finally comes to the notice of the Senate's Standing

\footnotetext{
${ }^{5}$ Shahram Haq and Farooq Tirmizi, "No lights at tunnel's end," April 10, 2012, the Express Tribune, $<$ http://tribune.com.pk/story/362306/no-light-at-tunnels-end-strapped-for-solutions-provinces-toshare-shortage/>, accessed on September 16, 2015

${ }^{\frac{6}{6}}$ Daily Times, "MPAs pass resolution to ban late night mobile packages," February 3, 2010,< http://archives.dailytimes.com.pk/lahore/03-Feb-2010/mpas-pass-resolution-to-ban-late-night-mobilepackages $>$, accessed on September 16, 2015

${ }^{7}$ Murtaza Ali Jafri, "Politics or parenting?" March 10, $2010<$

http://www.dawn.com/news/813185/politics-or-parenting>, accessed on September 16, 2015
} 
Committee on Information Technology and Telecom, which asked the Pakistan

Telecommunication Authority (PTA) to issue directives for bringing an end to all late night packages and chat room services. PTA, following instructions of the Standing Committee, issued a directive in the same effect. All five telecommunication companies operating in Pakistan together challenged the directive immediately in the Islamabad High Court only to withdraw their application and filing a review petition in the Supreme Court. ${ }^{8}$ Jamal Shahid writes in the Dawn, "Technically, there exists no law that would allow that [stop late night mobile packages]." In about a month's time, the operators, reports Dawn, "simply started offering the services under different names." ${ }^{10}$ In its editorial, the Dawn writes, "intermingling of young men and women is not a matter that should concern the state which has nothing to gain except opprobrium by acting as self-appointed guardian of society's morals." 11 The subject since then has not resurfaced while the late night packages and bundles are still being offered.

In 2014, upon the recommendation of the World Health Organization, Pakistan made it mandatory for all the travellers going abroad to carry a polio vaccination certificate as a proof that they have received at least one dose of polio vaccine. Pakistan is among a handful of countries where poliovirus is not only persisting but being exported to other countries too. In May 2014, the International Health Regulation, which represent an agreement between 196 countries and coordinated by the World Health Organization to work together for global health security including specific measures at ports, airports and ground crossings to limit the

\footnotetext{
${ }^{8}$ The Express Tribune, "Background: Ban on call packages result of domino effect, January 21, 2013 $<$ http://tribune.com.pk/story/496633/background-ban-on-call-packages-result-of-domino-effect/>, accessed on September 16, 2015

${ }^{9}$ Jamal Shahid, "No law exists to stop late night mobile packages," the Dawn, August 30, $2015<$ http://www.dawn.com/news/1039298>, accessed on September 16, 2015

${ }^{10}$ AFP, "The love chatroom crackdown," the Dawn, September 13, $2013<$ http://www.dawn.com/news/1042596>, accessed on September 16, 2015

${ }^{11}$ Dawn, "Unwanted morality brigade: PTA ban on mobile phone packages," September 1, $2013<$ http://www.dawn.com/news/1039802>, accessed on September 16, 2015
} 
spread of health risks to neighbouring countries, issued a 'temporary recommendation' that residents or long-term visitors from Pakistan should receive a documented polio vaccine between 4 weeks and 12 months before leaving the country. ${ }^{12}$ The travel restriction was applied from June 1, 2014 for all travellers. Soon after the emergency measures were put in place, it confounded into, what the daily Dawn dubs, a "real mess." ${ }^{, 13}$ Emergency anti-polio counters setup at the airports were flooded with passengers, though the facility was only for urgent travellers. Many did not receive any information and others had no idea where to go to receive polio vaccinations. At the government hospitals, where the polio counters were setup for this purpose, hundreds of people lined up to receive the vaccination. Vaccination arranged for 10 days ran out in only two days along with the other essential supplies, i.e. stationery. ${ }^{14}$ This was already expected for about 30,000 Pakistanis travelling abroad every day for which the vaccination was not available at the first place. Within days, fake certificates were available from photocopier shops in only US\$2. ${ }^{15}$ A rift between the Federal Investigation Authority and the Polio Cell on why the polio workers are issuing vaccination certificates instead the airport doctor resulted into polio vaccination being halted at the airports altogether. ${ }^{16}$ In November 2014, the World Health Organization issued another statement on the third meeting of the International Health Regulation extending the temporary recommendation for a further three months. ${ }^{17}$ The statement asked Pakistan to "restrict at the point of departure the international travel of any resident lacking

\footnotetext{
${ }^{12}$ For more details on International Health Regulation, visit: http://www.who.int/ihr/about/en/; WHO directive is available at: http://www.who.int/ith/updates/20140612/en/

${ }^{13}$ Aamir Yasin and Ikram Junaidi, "Polio certificate for air travelers is a messy affair," Dawn, June 3, 2014 http://www.dawn.com/news/1110267, accessed on September 16, 2016

${ }^{14}$ Ibid

${ }^{15}$ Ikram Junaidi, "People turning up with fake vaccination card," Dawn, July 10, 2014 http://www.dawn.com/news/1118278, accessed on September 16, 2016

${ }^{16}$ Umer Farooq, "Travel requirement: FIA, CAA to deliberate strategy for polio vaccination certificate," the Dawn, April 26, 2015 http://tribune.com.pk/story/875976/travel-requirement-fia-caato-deliberate-strategy-for-polio-vaccination-certificates/, accessed on September 16, 2015

${ }^{17}$ Statement is available at http://www.who.int/mediacentre/news/statements/2014/polio20141114/en/, accessed on September 15, 2015
} 
documentation of appropriate polio vaccination," and in case "existing and additional Temporary Recommendations...cannot be fully implemented by the time the Committee next meets, the Committee will consider additional measures such as entry screening to reduce the risk of international spread." The statement further asked Pakistan to "maintain these measures until at least 6 months have passed without new exportations" and "there is documentation of full application of high quality eradication activities in all infected and high risk areas; in the absence of such documentation these measures should be maintained until at least 12 months have passed without new exportations." Six months latter in March 2015, the World Health Organization extended restrictions once more for another three months. ${ }^{18}$ By that time, the steam had long run out and virtually nowhere at border checkpoints the vaccination card was demanded from travellers.

In 2009, the Local Government in Lahore decided to fix the price of 'samosa,' a baked pastry with savoury filling, at rupees 6 a piece. When an action was taken against a few backers selling samosas at higher prices, the Punjab Bakers and Sweet Federation decided to file a petition in the Lahore High Court, which was turned down. They then went into the appeal in the Supreme Court, which decided in favour of the backers and ruled that it is not in the purview of the government to fix prices of 'samosa.' While samosas were already sold in different range of prices, some higher than rupees 6, Dawn questions, "Was it the court's best use of time at this stage?"19 In another article in Dawn, Shyema Sajjad take both the decisions to control the prices of samosa and the verdict by the Supreme Court to strike the same sarcastically, “The Punjab Government's creativity and wisdom has tackled some great issues recently - some quite crucial too; the samosa..." and "Now why would the Supreme

\footnotetext{
${ }^{18}$ Ikram Junaidi, "WHO extends travel restricts for Pakistan after poliovirus export," Dawn, March 5, 2015, http://www.dawn.com/news/1167501, accessed on September 16, 2015

${ }^{19}$ Dawn, Samosa Justice, July 26, 2012 http://www.dawn.com/news/737259/samosa-justice, accessed on September 16, 2015
} 
Court actually take the time out for the samosa ruling is anybody's guess. Was the Supreme Court worried about Punjab's nutrition?"20 Habib calling it a "populist directive" on which "the two honourable superior courts thus took three years to settle or rather unsettle the spat over samosa prices that during this span had already doubled, spurning the six-rupee strictures slapped on them,"21 Tausif Kamal writes in Pakistan Today of country's senior judiciary at the time, "no matter how strong populist pressures are or how tempting or craven judicial intervention might seem to be. If not, then not only the rule of law would be in serious danger of being compromised but it would concomitantly trigger debilitating damages to the nation's stability and economy.",22

The abovementioned cases are just a few from a large section of administrative, judicial and executive policy decisions taken during the tenure of the last civilian government [20082013] in Pakistan. With policy decisions like implementing daylight saving time when it was already tried twice and failed miserably, calling for imposing a ban on late night call packages with no legal backing, making polio vaccine certification mandatory for all international travellers without having the required apparatus in place and setting the price of samosas by senior judiciary in the backdrop of its populist outlook the question whether these are effective policy measures or will they be yielding results or not become secondary. Perhaps, the more meaningful quest is then to find out the motives behind such decisions. Such a quest may also reveal the likely effectiveness of these decisions.

\footnotetext{
${ }^{20}$ Shyema Sajjad, "Justice, samosa and the ostrich," Dawn, July 27, 2012 http://www.dawn.com/news/737658/justice-for-ostriches-and-samosas, accessed on September 16, 2015

${ }^{21}$ Habib, E., "Sugur, Samosas, CNG and Supreme Court, Daily Times, December 22, 2012, p. A6

${ }^{22}$ Tausif Kamal, "A welcome decision," Pakistan Today, November 22, 2014, http://www.pakistantoday.com.pk/2014/11/22/comment/a-welcome-decision-5/, accessed on September 16, 2015
} 
This research entitled "Public Policy and Ideation: A Case of a Grey-Zone Country Pakistan," aims at studying the underlying motivations and the role of ideation in policymaking by taking the case of Pakistan. This research is not concerned with how effective the policymaking process is or how impactful its results might be; rather it is an exploration of those factors that become basis for policy actors, whether inside or outside the decision making circles, for making certain policy choices over others. In other words, the research is aimed at producing knowledge of the policy process, that is how and why of policymaking, rather than knowledge in the policy process which is referred to analysis and evaluation of policies. ${ }^{23}$ It is at the heart of public policy to know why and how particular decisions are made. ${ }^{24}$

\footnotetext{
${ }^{23}$ Nowlin, Matthew C., "Theories of the Policy Process: State of the Research and Emerging Trends," The Policy Studies Journal, Vol. 39, No. S1 (2001): 41

${ }^{24}$ Cairney, P., Understanding Public Policy: Theories and Issues (London: Palgrave MacMillan, 2012): 1
} 


\section{DECLARATION}

I hereby declare that this submission is my own work and that, to the best of my knowledge and belief, it contains no material previously published or written by another person nor material which to a substantial extent has been accepted for the award of any other degree or diploma of the university or other institute of higher learning, except where due acknowledgement has been made in the text. Where reference is made to previous academic work, due acknowledgement of the respective author(s) is made both in the text and in bibliography of this dissertation.

Furthermore, I endeavored to maintain my study as adherent as possible to the "Guidelines for Good Scientific Practice" (Leitlinien guter wissenschaftlicher Praxis) cited under $\$ 9$ of the Promotionsordnung des Promotionsstudiengangs "International Development Studies", to the best of my ability.

Errors and omissions in this document remain my personal responsibility.

Atif Ikram Butt

Bochum, Germany 2017 


\section{ACKNOWLEDGMENT}

First and foremost, I would like to express my sincere gratitude and thanks to my advisor Professor Dr. Marianne Kneuer. You have been a tremendous support for me throughout my research. How can I ever forget that even though you were extremely busy but still you agreed to provide me with invaluable guidance during my proposal development stage? It is only because of your guidance that I was able to develop a well-defined research plan. To say the least, it is because of your leadership that I was accepted as a Doctoral Fellow at the Institute of Development Research and Development Policy (IEE), Ruhr University Bochum and able to win a highly competitive and prestigious scholarship from the Heinrich Böll Stiftung. You have been truly, in every sense of the words, a mentor, a coach and even more importantly a counsellor. I simply would have not reached to this stage of my career without your able guidance and continuous encouragement. Dr. Kneuer, I would like to thank you for believing in me and allowing me to grow academically and professionally under your supervision. I will always be indebted to you for your unwavering support.

I would also like to thank my second supervisor, Professor em. Dr. Uwe Andersen. I am extremely thankful for your valuable comments and suggestions that have helped me greatly in further improving my research. I am extremely grateful of my senior colleagues at the IEE, especially Professor Dr. Wilhelm Löwenstein, Dr. Gabriele Bäcker and Dr. Anja 
Zorob, for making available all possible resources and providing valuable inputs to my research in colloquiums and cluster meetings. I would like to especially thank you for creating numerous opportunities for students at the IEE to help them broaden their professional network and gain greater exposure.

I am very thankful to my fellow colleagues at the IEE who made it truly a great learning and enjoyable experience for me. I will always cherish those moments spent in University's cafeteria with fellow colleagues motivating me at every stage of my research and helping me remained focus. I am very thankful to the administration at the IEE who facilitated me immensely throughout my stay in Germany.

I would also like to commend the financial support, which the foundations like the Heinrich Böll Stiftung are providing to hundreds of deserving students in Germany enabling them to continue with their higher education.

I am very much indebted to my family who supported me in every possible way to see the completion of this work. Above all, I am thankful to Allah Almighty for giving me health, strength and wisdom to undertake and complete this research. 


\section{LIST OF TABLES AND FIGURES}

Table 3.1 Types of Ideas and their Effect on Policy Making

Figure 4.1 Actors Affecting Public Policy Process and Outcome in Ideational Understanding

Table 4.1 Applying the Concept of 'Regulatory Conversations' to the Ideational Framework of Public Policy

Table 4.2 Ideational Framework of Public Policy

Table 5.1 Administrative Units of Pakistan

Table 5.2 Total Number of Seats in the National and Provincial Assemblies of Pakistan by Provinces and Regions

Table 5.3 Comparison of Provincial Local Government Acts by Provinces

Table 5.4 General Contents of the Rules of Business of the Provincial Governments

Table 5.5 A Process of Legislative Law Making in Pakistan (Non-money bills)

Table 5.6 Legislative Performance of the Five Years of the Thirteenth National Assembly of Pakistan, $2008-2013$

Table 6.1 Privatisation in Pakistan by Completed Transactions and Volume

Figure 6.1 Interest groups Membership, Participation and Intermediation in Public Policy Making

Table 7.1 Democracy Classification of Pakistan as per various Indices

Table 7.2 The Ten-Step Framework of Hajer's Discourse Analysis

Table 8.1 A Process of Legislative Law Making in Pakistan (Non-money bills)

Table 8.2 Timeline to organ transplantation law in Pakistan

Table 8.3 International Instruments on Free and Compulsory Education and Status of Pakistan

Table 8.4 Timeline to the Right to Free and Compulsory Education Act, 2012 in Pakistan

Table 8.5 List of Interviews conducted for the Protection Against Harassment of Women at 
the Workplace Act, 2010

Table 8.6 List of Interviews conducted for the Transplantation of Human Organs and

Tissues Act, 2009

Table 8.7 List of Interviews Conducted for the Right to Free and Compulsory Education

Act, 2012 


\section{GLOSSARY OF KEY CONCEPTS}

Discourse

Government

Grey Zone Countries

Ideas

Institutions

Policy as discourse
Discourse is not merely an instrumental intentional means of information exchange but also has constructive and interpretive abilities central to development and sustenance of shared meanings and common identity and an agent's own interpretations and actions within particular institutional setting.

Government is a group of people having "regulating power over society."

Grey-zone countries are those that have some attributes of democratic political life, i.e. regular elections or a democratic constitution, yet they suffer from serious democratic deficits, i.e. poor representation of citizens' interests and persistently poor institutional performance by the state, and, therefore, fall somewhere between the two extremes of an outright dictatorship and well-established liberal democracy

Ideas are the basis for policy decisions, central to how policymakers conceive and evaluate their options and how and what they decide.

Institutions are rule-like collection of ideational constructs that structure or influence behaviour and affected by its institutional environment itself for its subsequent design and development.

Policy-as-discourse conceives policy process as strategic and political where no social actor stands outside it and where there is deeper reflection 
on the contours of a particular policy discussion, the shape assigned to a particular problem.

Public Interest Theory Public interest theory holds that government regulations are an instrument for overcoming market failures of imperfect competition, unbalanced market operation, missing markets and undesirable market results.

Public Policy Public policy is understood as a purposeful course of action taken by the government that affects a segment of the society. It is in the form of a law, statute, regulation, rule or legislation and therefore follows a certain authority and coercion.

Regulation Regulation' is seen through different characteristics as "a specific set of commands," which have "deliberate state intent" and that pertains to "all forms of social control or influence. 


\section{LIST OF ACRONYMS AND ABBREVIATIONS}

\begin{tabular}{|c|c|}
\hline AASHA & Alliance Against Sexual Harassment \\
\hline AJK & Azad Jammu and Kashmir \\
\hline CEDAW & Convention on the Elimination of all Forms of Discrimination Against Women \\
\hline CERAT & Research Center on Territorial Planning \\
\hline DFID & Department for International Development \\
\hline DST & Daytime Saving Time \\
\hline ESTA & Civil Establishment Code \\
\hline FATA & Federally Administered Tribal Areas \\
\hline GB & Gilgit Baltistan \\
\hline HEC & Higher Education Commission \\
\hline HOTA & Human Organ Transplantation Authority \\
\hline ICT & Islamabad Capital Territory \\
\hline ILO & International Labour Organization \\
\hline IEE & Institute of Development Research and Development Policy \\
\hline KP & Khyber Pakhtunkhwa \\
\hline NGO & Nongovernmental Organisations \\
\hline NHS & National Health Service \\
\hline NWFP & North-West Frontier Province [formerly] \\
\hline PAUS & Pakistan Association of Urological Surgeons \\
\hline PML-N & Pakistan Muslim League - Nawaz \\
\hline PML-Q & Pakistan Muslim League - Quaid \\
\hline PSN & Pakistan Society of Nephrology \\
\hline PTA & Pakistan Telecommunication Authority \\
\hline SIUT & Sindh Institute of Urology and Transplantation \\
\hline
\end{tabular}


UDHR Universal Declaration of Human Rights

UK United Kingdom

UNDP United Nations Development Programme

UNESCO United Nations Educational, Scientific and Cultural Organization

UNICEF United Nations Children's Fund

TSP Transplantation Society of Pakistan

UN United Nations

US United States

VNC Village and Neighbourhood Council

WHO World Health Organization 


\section{ABOUT THIS RESEARCH}

\section{1: INTRODUCTION}

he history of public policy is as old as the notion of a 'government'. The
scholarly quest of developing a deeper understanding on how and why public
policies evolve is also at least two centuries old. Yet, existing theories of public policy fall short of capturing the politics and environment of policymaking in developing countries and characterise features such as those represented by the United States or the continental Europe. By taking the case of Pakistan, the research sets the objective of filling-in this theoretical gap through post-empirical analysis of social-sector policymaking in one of the grey-zone countries.

This research is essentially about what constitutes public policy process and how its outcomes are arrived, changed, stay stable, vary from sector to sector or from one region to another. ${ }^{1}$ In this introductory chapter the foundation is set for this research. It begins with a brief history of public policy from prescriptive science as in the Lasswellien aspiration in early days to the ascendency of behaviouralism in between and finally the realisation of postpositivist orientation through critique of "serious epistemological failures of the positivist

\footnotetext{
${ }^{1}$ John, P., "Is there Life After Policy Streams, Advocacy Coalitions and Punctuations: Using Evolutionary Theory to Explain Policy Change," The Policy Studies Journal Vol. 31, No. 4 (2003): 481
} 
approach." ${ }^{2}$ The term 'public policy' is then defined in the perspective of this research in the section that follows this. This is followed by a section based on contemporary debates on 'theory development' leading to a discussion on merits and demerits of applying 'synthesis' and for introducing contours of a more rounded theory of public policy which does not subscribe to any particular regime type. It also provides a brief overview of existing set of theories of public policy and limitations therein. The last section provides the plan of this thesis.

\section{2: A BRIEF HISTORY OF PUBLIC POLICY}

Public policy, as a concept, is as old as the existence of 'government.' As Smith and Larimer write that "what government do or do not do has occupied the attention and interest of humans ever since there were governments." 3 But as a distinct academic discipline devoted to studying the decision-making of the government, the field of public policy only started emerging during the middle of the twentieth century. It could be argued, as McCool writes, that Plato had perhaps first laid out the foundation of public policy in $360 \mathrm{BC}$ in The Republic or it was much later in the 16th-century work of Machiavelli, most notably The Prince. ${ }^{4}$ So, while "the study of public policy did not suddenly sprint into existence" as McCool notes, the classic literature that founded the discipline is only about fifty years old, beginning with the work of Harold D. Lasswell. ${ }^{5}$ Most academicians agree that the discipline referred to as the study of public policy grew out of policy sciences approach, particularly in the work of

\footnotetext{
${ }^{2}$ Deleon, P., "The Historical Roots of the Field," in Michael Moran, Martin Rein and Robert E. Goodin (eds.) The Oxford Handbook of Public Policy (Oxford: Oxford University Press, 2006): 51

${ }^{3}$ Smith, Kevin B. and Larimer, Christopher W., The Public Policy Theory Primer, 2nd ed. (Philadelphia: Westview Press, 2013): 7

${ }^{4}$ McCool, Daniel C., Public Policy Theories, Models and Concepts: An Anthology (New Jersey: Prentice-Hall, 1995): 1

${ }^{5}$ Birkland, Thomas A., An Introduction to Policy Process: Theories, Concepts and Models of Public Policy Making 3rd ed. (New York: M.E. Sharpe, 2011): 7
} 
Lasswell of late 1940s and early 1950s. ${ }^{6}$ In his essay, "The Policy Orientation," Lasswell for the first time clearly enunciated the need for "scientific study of policy.", Lasswell, in the same essay, outlines the main contents of policy sciences as "the method by which the policy process is investigated, the result of the study of the policy, and the findings of the disciplines making the most important contribution to the intelli 'gence needs of the time." He continues that if "we are to advance in our scientific grasp of the policy formulation and execution process as a whole, it is obviously essential to apply and improve the methods by which the psychological and social-scientific investigations are made."

Lasswell's call for the policy sciences, writes McCool, at the time was largely unheeded and "it was not until the late 1960s that the study of public policy began to blossom and gain credibility. $" 9$ McCool points at several reasons, i.e. lack of specialists trained in policy analysis, unavailability of computers necessary to handle huge datasets and behaviouralist revolution of the time, due to which the idea could not gain immediate credence when first introduced. ${ }^{10} \mathrm{Pal}$ writes "the terms public policy and policy analysis began to be used more frequently in the 1960s as the American government began to try to solve problems in a host of areas from racial conflict, urban renewal, transportation and education [emphasis removed]." ${ }^{\prime 11}$ By the late 1960s, write Stewart et al, "the policy studies subfield has developed into a well-organized body of work with courses, curricula, schools of public policy, organisations, journals, textbooks, conferences, panels, summer institutes, awards, funding

\footnotetext{
${ }^{6}$ Deleon, P., 2006: 39

${ }^{7}$ Lasswell, Harold D., "The Policy Orientation," in Daniel Lerner and Harold D. Lasswell (eds.) The Policy Sciences: Recent Development in Scope and Method (Stanford: Stanford University Press, 1951): 3

${ }^{8}$ Ibid, 4

${ }^{9}$ McCool, Daniel C., 1995: 3

${ }^{10}$ Ibid

${ }^{11}$ Pal, Leslie A., Beyond Policy Analysis: Public Issue Management in Turbulent Times, 4th ed. (Toronto: Nelson, 2010): 27
} 
sources, research institutes and job opportunities." ${ }^{12}$ In the 1950s and the early 1960s, when the field originated, the focus of policy studies was on the problem of policy formulation. The primary method of research used at the time was case study and results were largely qualitative and pre-behavioural. ${ }^{13}$ The focus, however, started switching by early 1960 s to quantitative statistical techniques reflecting the ascendency of positivism with a view that public policy could be studied scientifically. ${ }^{14}$ According to Blackmore and Lauder, 'rationalist' approaches to policy analysis dominated the field of policy studies up until the 1970s. ${ }^{15}$ From the 1970 s, Goodwin argues, “ rationalist orientation in policy analysis were strongly criticised, the rise of critical social science and the emergence of feminist perspectives on research practices all questioned the purported value neutrality of the research methods underpinning the rationalist approach." ${ }^{16}$ It was only by mid 1990s that the positivist paradigm in policy studies was challenged from post-positivists arguing that public policy phenomena cannot be studied with scientific methods and rigorous statistical techniques. This has brought about; argue Stewart et al, "a healthy reconciliation" and a shift whereby "policy scholars now rely on mixed methods."17

Torgerson distinguishes three distinct phases in the field of policy sciences starting from positivism, where knowledge purports to replace politics, to its critique where politics purports to replace knowledge and finally to post-positivism where knowledge and politics in

\footnotetext{
${ }^{12}$ Stewart, J., Hedge, David M. and Lester, James P., Public Policy: An Evolutionary Approach, 3rd ed. (Boston: Thomson Higher Education, 2008): 12

${ }^{13}$ Ibid, 13

${ }^{14}$ Ibid

${ }^{15}$ Blackmore, J. and Lauder, H., "Research Policy," in B. Somekh and C. Lewin (eds.), Research Methods in Social Sciences (London: Sage, 2005): 97 - 104

${ }^{16}$ Goodwin, S., "Analysing Policy as Discourse: Methodological Advances in Policy Analysis," in Lina Markauskaite, Peter Freebody and Jude Irwin (eds.) Methodological Choice and Design:

Scholarship, Policy and Practice in Social and Educational Research (London: Springer, 2011): 169

${ }^{17}$ Ibid
} 
his view attain a measure of reconciliation. ${ }^{18}$ Because the field of policy studies is so new, many of the fundamentals of the policy sciences have only begun to be well understood in the last twenty years or so. Considerable debate remains over whether there is one coherent set of principles that can govern the study and understanding of what we call the public policy process. $^{19}$

\section{3: DEFINING PUBLIC POLICY}

There is no scholarly consensus over the precise definition of the term 'public policy.' For many people defining public policy helps them define their own role in the study and practice of policymaking. ${ }^{20}$ Thomas Dye agues that trying to find a precise definition of public policy can "degenerate into a word game" that, eventually, adds little to our understanding. ${ }^{21}$ His own definition of public policy as "whatever governments choose to do or not to do" is perhaps the most widely cited definition in policy studies literature. ${ }^{22}$ Minimalist definitions, such as the one put by Howlett and Ramesh "a choice made by government to undertake some course of action," or the one by Eisner et al who define public policy as "patterns of governmental action or inaction," have been criticised for being too general and effectively encompasses everything within the ambit of public policy for a government. ${ }^{23}$ Cochran et al provide a more elaborated conception of public policy and define it as "an intentional course of action followed by a government institution or official for resolving an issue of public

\footnotetext{
${ }^{18}$ Torgerson, D., "Between Knowledge and Politics: Three Faces of Policy Analysis," Policy Sciences, Vol. 19 (1986): 35

${ }^{19}$ Birkland, Thomas A., 2011: 7

${ }^{20}$ Birkland, Thomas A., 2011: 7

${ }^{21}$ Dye, Thomas R. Understanding Public Policy 13th ed. (New York, Prentice Hall, 2007): 19

${ }^{22}$ Dye, Thomas R., Understanding Public Policy (Englewood Cliffs, N.J.: Prentice Hall, 1972): 1

${ }^{23}$ Eisner, Marc A., Worsham, J. and Ringquist, Evan J., Contemporary Regulatory Policy 2nd ed. (Boulder CO: Lynne Rienner, 2006): 2; Howlett, M. and Ramesh, M. Studying Public Policy: Policy Cycles and Policy Subsystems, 2nd ed. (Don Mills, ON: Oxford University Press, 2003): 5
} 
concern. ${ }^{24,}$ Fawcett et al define public policy in similar lines as concerning "with the principles and practices of pursuit by government of social, political and economic outcomes. ${ }^{25}$ In this conception too, public policy relates to the functioning of government. As Cochran et al argue, "The term public policy always refers to the actions of government and the intentions that determine those actions. ${ }^{26 "}$ The definition of Cochran et al is different from the ones offered by Dye and Eisner et al in two respects; one the omission of 'inaction' from the wordings and second the inclusion of 'intentional course of action.' Cochran et al rightly elaborate that such a course of action must be manifested in laws, public statements, official regulations, or widely accepted and publicly visible patterns of behaviour. ${ }^{27} \mathrm{~A}$ slightly more elaborated definition is of Peters Guy who sees public policy as "the sum of government activities, whether acting directly or through agents, as it has an influence on the life of citizens. ${ }^{28,}$ In this definition, Peters not only highlights on the source of public policy, which is the government, but also the eventual direction it takes, i.e. influence on the life of citizens. Cochran and Malone also define public policy on similar lines and consider it consisting of "political decisions for implementing programs to achieve societal goals. ${ }^{29, "}$ Thus far, public policy is understood as a government prerogative, a purposeful action, and having influence on some section of the society. Newton and van Deth definition of public policy as "a long series of activities, decisions and actions carried out by officials of government in their attempts to solve problem that are thought to lie in the public or collective arena," expands the concept even further and adds a temporal dimension as well,

\footnotetext{
${ }^{24}$ Cochran, C., Mayer, L., Carr, T. and Cayer, N., American Public Policy: An Introduction, 9th ed. (Boston, MA., Wadsworth Cengage Learning, 2006): 2

${ }^{25}$ Fawcett, B., Goodwin, S., Meagher, G., and Phillips, R., Social Policy for Social Change

(Melbourne: Palgrave MacMillan. 2010)

${ }^{26}$ Ibid, 1

${ }^{27}$ Cochran, C., Mayer, L., Carr, T. and Cayer, N., 2006: 2

${ }^{28}$ Peters, G., American Public Policy: Promise and Performance (New York: Chatham House, 1999): 4

${ }^{29}$ Cochran, C. and Malone, E. Public Policies: Perspectives and Choices (Boston: McGraw-Hill

College, 1999): 5
} 
while retaining the normative aspect of Cochran and Malone. ${ }^{30}$ Anderson also favours precise definition or concept needed to a systematic analysis of public policy and argues against minimalist definitions as being adequate for ordinary discourse only. ${ }^{31}$ Much in the same lines as Newton and van Deth, Anderson defines public policy as "a relatively stable, purposive course of action followed by government in dealing with some problem or matter of concern." In this conception, Anderson is subsuming what followed, or should be followed, after a public policy is originated in his conception of the term. Importantly, Anderson in his analysis also highlights the main characteristics of public policy as a goaloriented action, which is taken over time and emerges in response to policy demands. For Anderson, public policy involves what government actually do and not just what they intend to do and is based on law and is authoritative. He, however, concurs that a public policy may have positive or negative facets. ${ }^{32}$ Cochran et al also understand public policy to be rooted in law and in the authority and coercion associated with law. ${ }^{33}$ Birkland, on the other hand, takes the approach suggested by Thomas Dye of breaking down this general notion into various components for defining public policy. ${ }^{34}$ He outlines several possible definitions of public policy and then traces out elements of commonality. He writes, agreeably, "No single definition may ever be developed, but we can discern key attributes of public policy." ${ }^{, 35}$ His analysis indicates that elements common to most of the definitions are that it is made by government in the name of public and interpreted and implemented by public and private players from corporations and non-profit institutions as well as it includes what the

\footnotetext{
${ }^{30}$ Newton, K. and van Deth, J. W., Foundation of Comparative Politics, 2nd ed. (Cambridge: Cambridge University Press, 2010): 315

${ }^{31}$ Anderson, James E., Public Policymaking, 8th ed. (Stamford: Cengage Learning: 2003): 7

${ }^{32}$ Ibid, $8-9$

${ }^{33}$ Cochran, C., Mayer, L., Carr, T. and Cayer, N., 2006: 2

${ }^{34}$ Dye, Thomas R., 1972: 1

${ }^{35}$ Birkland, Thomas A., 2011: 8
} 
government chooses not to do. ${ }^{36}$ Birkland, however, broadly conforms to the definition of Thomas Dye as "what the government, acting on our behalf, choses to do or not to do. ${ }^{37 \text { " }}$

For the purpose of this research, rather than conforming to one particular definition, the term 'public policy' is seen from its defining characteristics. Public policy is understood as a purposeful course of action taken by the government that affects a segment of the society. It is in the form of a law, statute, regulation, rule or legislation and therefore follows a certain authority and coercion. Public policy is seen as forming a subset of 'policy' which is defined more broadly in the words of Anne Schneider and Helen Ingram as being "revealed through texts, practices, symbols and discourses that define and deliver values including goods and services as well as regulation, income, status and other positively or negatively valued attributes. ${ }^{38}$ Therefore, the comprehension of public policy for this research distinguishes from the understanding that it also entails what government choses not to do. This inaction or lack of definitive statement on part of any government is seen more of an evidence of an implicit policy than a public policy per say.

\section{4: THEORISING PUBLIC POLICY}

Harold Lasswell is usually attributed as the founder of the policy sciences. ${ }^{39}$ Lasswell and early scholars saw policy sciences in terms of three defining characteristics, to which deLeon

\footnotetext{
${ }^{36}$ Gomery, D., "Public Policy," in William A. Darity Jr. (ed.) International Encyclopedia of the Social Sciences, 2nd ed., Vol. 6 (Detroit: MacMillan, 2008): 619

${ }^{37}$ Birkland, Thomas A., 2011: 203

${ }^{38}$ Schneider, A. and Ingram, H., Policy Design for Democracy (Lawrence, University of Kansas Press, 1997): 2

${ }^{39}$ Fischer, F., Miller, Gerald J., and Sidney, Mara S. (eds.), Handbook of Public Policy Analysis:

Theory, Politics and Methods (Boca Raton, FL: CRC Press, 2007): xix
} 
and Vogenbeck call the "central touchstones." 40 They wanted policy sciences to be problemoriented for addressing public policy issues, as well as multidisciplinary and normative and valued oriented in its approach. ${ }^{41}$ These characteristics are discernable in earlier theoretical contributions too, i.e. "comprehensive rationality" or stages heuristic models. As Cairney recounts, the focus of public policy initially was prescriptive to help "policymakers to better understand and make decisions." ${ }^{42}$ With this ambit, Smith and Larimer call 'policy stages' as a first attempt at policy theory that conceives "public policy as a linear decision-making process of linked stages that very much reflects a rationalist perspective." ${ }^{, 3}$ The theory is, however, criticised for not being able to explain why the process happens the way it does. ${ }^{44}$ Sabatier agrees, "Until the mid-1980s, the most influential framework for understanding the policy process was the "stages heuristic," but it has "outlived its usefulness and needs to be replaced with better theoretical frameworks." 45 The concepts of 'comprehensive rationality,' also among the initial contributions to the field of policy sciences, entails following logical stages of policymaking by comprehensively studying the context to maximise the benefits of the policy for the society. ${ }^{46}$ Such prescriptive approaches served as a departure point for descriptive study of public policy.

From "comprehensive rationality, the theories of incrementalism and 'bounded rationality' were introduced to describe how policy decisions are actually made. ${ }^{47}$ In incremental decision-making, Lindblom maintains that when faced with complex problems, policymakers

\footnotetext{
${ }^{40}$ deLeon, P. and Vogenbeck, Danielle M., "The Policy Science at the Crossroads," in Frank Fischer, Gerald J. Miller and Mara S. Sidney (eds.), Handbook of Public Policy Analysis: Theory, Politics and Methods (Boca Raton, FL: CRC Press, 2007): 4

${ }^{41}$ Ibid

${ }^{42}$ Ibid

${ }^{43}$ Ibid, 29

${ }^{44}$ Ibid, 26

${ }^{45}$ Paul A. Sabatier (ed.), Theories of the Policy Process (Boulder, Colorado: Westview Press, 2007): 7

${ }^{46}$ Ibid, 5-6

${ }^{47}$ Ibid, 6
} 
seek shortcuts and restrict consideration to only those alternatives that are marginally different from the status quo." ${ }^{48}$ Bounded rationality, emerged as a critique of fully rational decision making, and points to the limits of rational adaptation, and described a policy making process in which decision makers rely on shortcuts rather than comprehensive analysis and seek satisfactory solutions rather than optimal ones. ${ }^{49}$ In addition to stages heuristic models, 'policy typology' also continues to serve as a standard conceptual tool. ${ }^{50}$ Based on the work of Theodore Lowi, who was interested in examining the different types of public policy and their effect on politics, the framework of 'policy typology' postulates that one could predict the type of politics to follow if the type of policy is determined. One of the basic critiques of the 'policy typology' was that most policies do not fit neatly within a single category as described by Lowi. ${ }^{51}$ Policy analysis, since then, has mostly taken an empirical orientation. Fisher et al argue that there has been "an emphasis on rigorous quantitative analysis...the limited framework becomes a policy science that would be able to develop generalizable rules applicable to a range of problems and contexts." ${ }^{25}$ They contend, "this has been driven by the dominant influence of economics and its positivist scientific methodologies on the development of the field." ${ }^{, 53}$ Many rightly argue today, however, that policy does not follow standardised procedures or routinized approaches that it can be validated in a technically scientific sense. ${ }^{54}$

\footnotetext{
${ }^{48}$ Berry, Frances S. and Berry, William D., "Innovation and Diffusion Models in Policy Research," in Paul A. Sabatier (ed.), Theories of the Policy Process (Boulder, Colorado: Westview Press, 2007): 225

${ }^{49}$ Cairney, P., 2012: 6

${ }^{50}$ Ibid, 25

${ }^{51}$ Ibid, 39

${ }^{52}$ Fischer, F., Miller, Gerald J., and Sidney, Mara S. (eds.), Handbook of Public Policy Analysis: Theory, Politics and Methods (Boca Raton, FL: CRC Press, 2007): xix

${ }^{53}$ Ibid

${ }^{54}$ McCool, Daniel C. Public Policy, Theories, Models and Concepts: An Anthology (New Jersey:

Prentice Hall, 1995) 398
} 
The basic problem with public policy theories, Peter John agues, is that "many are not well adaptable to the many facetted character of the policy process, let alone many of those theories have difficulties of their own. ${ }^{55}$ For this reason, there is no single unifying theory of pubic policy. ${ }^{56}$ Smith and Larimer agree, "Public policy is such a diffuse topic that it is hard to even imagine a single, broad conceptual model that all policy scholars could practically adopt and apply." ${ }^{, 57}$ Cairney argues that it is difficult to predict public policy outcomes as the process becomes often messy with "many actors may be involved at various levels of government and their relationships vary across time and policy issues." ${ }^{, 58}$ Daniel McCool argues in similar lines, "the subject [public policy] is simply too diverse, the number of variables too immense, and the relationships too complex to be explained by a single theoretical approach." ${ }^{59}$ Greenberg et al concede that due to the complexities of public policy as an object of study, "we may never be able to obtain hard knowledge of the policy process of the type available in the advanced physical sciences. Yet improving our understanding of policy phenomena is clearly possible, if only through advancing the conceptual sophistication of theoretical formulations. ${ }^{, 60}$ Sproule-Jones argues that the fundamental dilemma public policy theorists face is the multidimensionality and interdependence between public policy because theory by definition is parsimonious. ${ }^{61}$ He recommends, "policy theorists must extend their theoretical work to combine much more of the interdependencies and multidimensionality of public policy." ${ }^{\prime 62}$ Cairney argues that the world of public policy world

\footnotetext{
${ }^{55}$ John, P., 2003: 483

${ }^{56}$ Cairney, P., Understanding Public Policy: Theories and Issues (London: Palgrave MacMillan, 2012): 1

${ }^{57}$ Smith, Kevin B. and Larimer, Christopher W., The Public Policy Theory Primer (Boulder, Colorado: Westview Press, 2013): 16

${ }^{58}$ Cairney, P., 2012, 9

${ }^{59}$ McCool, Daniel C., 1995: 8

${ }^{60}$ Greenberg, George D. et al., "Developing Public Policy Theory: Perspective from Empirical Research," The American Political Science Review, Vol. 71, No. 4 (1977): 1543

${ }^{61}$ Sproule-Jones, M., "Multiple Rules and the 'Nesting' of Public Policies," Journal of Theoretical Politics, Vol. 1, No. 4 (1989): 459

${ }^{62}$ Ibid, 476
} 
is so complex that producing any single theory is only possible if the approach of 'synthesis' is used for combining the insights of multiple theories, concepts or models. ${ }^{63}$ Peter John, a key proponent of the 'synthetic' approach, argues that any attempt at theorising public policy should take into account relationship between the five core causal processes [that are] institutions, networks, socioeconomic process, choices, and ideas. ${ }^{, 64}$ Parsons also considers public policy a complex activity that no single theory or model can explain and, therefore, "analysts must accept the pluralistic nature of the inquiry, both in terms of interdisciplinary quality of investigation and the need for hermeneutic tolerance of diversity." ${ }^{\circ 5}$ In last two decades, Sabatier writes, "a number of new theoretical frameworks of the policy process have been either developed or extensively modified," that combines insights from a range of theoretical frameworks, i.e. multiple streams analysis, punctuated equilibrium and advocacy coalition framework. ${ }^{66}$

On the basis of criteria of scientific rigour, Sabatier argues that, among others, multiple streams, punctuated equilibrium and advocacy coalition framework are worth the study but they all implicitly assume the basic features of American pluralism. ${ }^{67}$ Smith and Katikireddi make a similar assertion while applying contemporary theoretical development in the field of public policy, "no single theory offers a comprehensive description of the policy process and all are limited by their origins in high-income democratic settings with their relevance to low/middle income or less democratic settings remaining unclear." ${ }^{68}$ Cairney concurs, "There

\footnotetext{
${ }^{63}$ Cairney, P., "Standing on the Shoulders of Giants: How Do We Combine the Insights of Multiple Theories in Public Policy Studies?" Policy Studies Journal, Vol. 41, No. 1 (2013): 2

${ }^{64}$ John, P., 2003: 487

${ }^{65}$ Parsons, W., Public Policy: An Introduction to the Theory and Practice of Policy Analysis (Cheltenham: Edward Elgar, 1995): 73

${ }^{66}$ Cairney, P., 2012: 266

${ }^{67}$ Paul A. Sabatier (ed.), Theories of the Policy Process (Boulder, Colorado: Westview Press, 2007): 11

${ }^{68}$ Smith, Katherine, E. and Ketikireddi, Srinivasa V., "A Glossary of Theories for Understanding Policymaking," Journal of Epidemiology and Community Health, Vol. 67
} 
is good reason to think that punctuated equilibrium theory applies mostly to the US," and even outside US it is applied in Canada, the EU and other European countries where prerequisites of separation of power and multi-level governance are found. ${ }^{69}$ Similarly, advocacy coalition framework is also based on the US political system and is intended to apply to developed countries. ${ }^{70}$ This quandary points to another set of problem that besets the policy sciences in the context developing countries in as most of the scholarship on public policy has originated from a study of the US political system and is, at best, characterised by a separation of power. ${ }^{71}$ Osman argues that most of the "policy making theories were derived from the studies of industrially developed societies, which in most cases, are found insufficient to explain the policies of developing countries due to the contextual variations., 72 Osman further argues, "The structure of the political system greatly differs from the developed and developing countries. This makes the existing theories or models of public policy making derived from the developed countries inadequate to explain the policy making process of developing countries." ${ }^{, 73}$ Nelson also argues similarly, "the field of public policy is American in intellectual origin [and] is best understood as a view of policy that assumes stable democracy and the persistence of independent platforms outside government from which scholars can analyse and criticize the direction of public actions." ${ }^{74}$ Fischer et al argue that more recent development in the field of public policy have been defined by postpositivist, interpretivist, and social constructionist scholars. ${ }^{75}$ Goodwin, Rein and Moran agree, "Policy making and policy studies are essentially about persuasion," inspired by the

${ }^{69}$ Cairney, P., 2012, 196

${ }^{70}$ Ibid, 213

${ }^{71}$ Ibid, 5

${ }^{72}$ Osman, Ferdous, A., "Public Policy Making: Theories and their Implications in Developing Countries," Asian Affairs, Vol. 24, No. 3 (2002): 37

${ }^{73}$ Ibid, 38

${ }^{74}$ Nelson, Barbara I., "Public Policy and Administration: An Overview," in Robert E. Goodin and Hans-Dieter Klingemann (eds.), A New Handbook on Political Science (Oxford: Oxford University Press, 1998): 553

${ }^{75}$ Fischer et al. (eds.), 2007: xxv 
"argumentative turn" and the analysis of "discourses" of policy in the "critical policy studies" movement. ${ }^{76}$ This research also combines, as per the agenda Fischer lays out for policy inquire, a social constructionist view of social inquiry with the role of discourse and ideas within the overall paradigm of new institutionalism in the shaping of social explanation and understanding. ${ }^{77}$

\section{5: THE PLAN OF THIS THESIS}

This dissertation is arranged as such that each succeeding chapter provides impetus to the next but can also be read independent to others. Each chapter starts with a brief introduction that also provides its layout and ends with concluding words connecting it with the next chapter.

The second chapter discusses in detail the general theories of regulation. While regulation is a subset of public policy its theoretical foundation are at least a century older than of policy sciences itself. ${ }^{78}$ This chapter, therefore, delves deeper into the two main and contending sets of theories of regulation, namely the public interest and private interest theories. These two sets of theories are then studied from the prism of countries that do not necessarily present facets of pluralist societies, i.e. the United States (US), or of well-established liberal democracies but, rather, fall into the political grey-zone. The chapter makes the case that both sets of general theories of regulation implicitly subscribe to pluralistic liberal democracies and are foremost the representation of US political dynamics. Therefore, they have

\footnotetext{
${ }^{76}$ Goodin, Robert E., Rein, M., and Moran, M., "The Public and its Policies," in Michael Moran, Martin Rein and Robert E. Goodin (eds.) The Oxford Handbook of Public Policy (Oxford: Oxford University Press, 2006): 6

${ }^{77}$ Fischer, F., Reframing Public Policy: Discursive Politics and Deliberative Practices (Oxford: Oxford University Press, 2003): 13

${ }^{78}$ Eisner, Marc A., Worsham, J. and Ringquist, Evan J., Contemporary Regulatory Policy, $2^{\text {nd }}$ ed. (Boulder, CO: Lynne Rienner, 2006): p. 2
} 
questionable generality and could be of little service to a wide array of political regimes of grey-zone. The chapter makes the overall conclusion that theories of public policy in general and regular scholarship in particular needs further advancement through application of theoretical frameworks that are value-free and do not subscribe to, implicitly or explicitly, one or another form of political regime. The analytical construct of discursive institutionalism offers this flexibility to examine public policy making while encapsulating specific political, legal and cultural attributes of a particular regulatory setting. The central idea in this chapter is to discuss limitation of the two main contending theories of regulation in view of countries of grey-zone and build basis for using new institutionalism as an overall theoretical prism from which a more rounded theory can be developed.

Peter John, who has written extensively on public policy and also co-edits the Journal of Public Policy, asserts that the best candidate of an overarching paradigm for developing a holistic theory of public policy is institutionalism. ${ }^{79}$ The third chapter traces the institutional explanation of the processes by which public policies are made and evolved, which started quite independently in economics, sociology and political science, to most recent attempts within this scholarship of deciphering the role of ideas in public-policy outcomes. This chapter briefly reviews constituting factors of 'institutions' in new institutionalism and discuses the role ideas play therein. It then lays foundation for precisely defining the concept of ideas and their affects on public-policy outcomes within the ambit of a latest pillar ideational institutionalism - in new institutionalism. The chapter also plugs existing theoretical gaps in ideational scholarship by building conceptual clarity on types of ideas and their application on understanding public policy outcomes. This chapter brings out

${ }^{79}$ John, P., 2003: 483 
weaknesses of the three established schools in new institutionalism and build the case for applying ideational institutionalism to overcome those limitations.

Chapter four provides details of the overall research design and methodology applied for the purpose of this research within the ambit of ideational institutionalism. After having settled the issue of conceptual clarity, the mechanism through which ideas affect policy outcomes are also elaborated in this chapter. This builds the basis for the use of discourse analysis to allow for a better understanding on how some ideas become prominent over others and how do they cohere or collide. Also important is the origin of ideas, from where do they come from, on which there is already a substantial inquiry in new institutionalism scholarship. The existing research on the origin of ideas and their affects on public policy outcomes are primarily dealt with by centring either on 'agency' or the 'institution.' The research applies a wholesome approach by using the model of institutional environment, adapted from the work of Montzana et al, and tracing the origin of ideas and their affects on public policy outcomes starting with 'providers' and 'controllers' of polices to its 'supporters' and 'opponents' and finally by analysing the contribution of 'acceptors'. The purpose of this chapter is to introduce theoretical frameworks, models and tools applied in this research, and the reasoning behind their selection.

After having established the overall theoretical paradigm for understanding how and why public policies might be developed in grey-zone countries, chapter five provides detailed discussion on formal institutionalised mechanisms of forging and developing public policies in Pakistan. The aim of this chapter is to delineate generality of selecting Pakistan as a case study amongst the countries of the grey-zone. This chapter is essential in detailing how the formal mechanisms of policymaking are the attributing factors in why and how polices are 
come to shape. The chapter provides synopsis of basic constituting elements of the Federation of Pakistan, as well as its federating units and the three main branches of the government of Pakistan. This chapter, importantly, also makes the case of selecting the Thirteenth National Assembly of Pakistan, being the first civilian setup to have completed its constitutional tenure of five years, as a period of investigation for this research. Furthermore, the chapter also provides detail reasoning for selecting the three social-sector legislations as case studies for this research.

Chapter 6 builds on the previous chapter and sets the context for the core of this research by studying inclusiveness and contestation in policymaking in Pakistan. In this chapter, interest groups intermediation and their participation for understanding the extent to which the public policy process is inclusive and contested as well as its impact on the process of democratisation in Pakistan.

Before presentation of analysis, discussion thereupon and implications of the findings of the research in Chapter 8, Chapter 7 provides in detail the research methodology and design employed for this research. The Chapter provides the reason for using case study approach for this research as well as the justification for using Pakistan as study area. This Chapter also discusses the research framework employed to collect the information, the sample size and the sampling methodology as well as the unit of analysis and major sources of information accessed for collecting data for this research. It also contains details about collection of data and its recording and documentation and brief overview of the tools used to collect information as well as the steps taken to analyse date. The chapter also discusses limitations of this research. 
Chapter 8 of the dissertation provides results from this research on the selected cases of social sector policymaking in Pakistan. The aim of this chapter is to advance the agenda of ideational institutionalism for understanding the underlying reasons and mechanism through which policies are constructed in grey-zone countries. It provides details of main sources of information used for this research. The chapter is divided into three main sections each devoted to a particular social legislation passed during the five-year tenure of the Thirteenth National Assembly of Pakistan from 2008 till 2013. Each main section of this chapter first provides basic contours of the selected legislations. This is followed by in-depth study of ideational forces as well as a timeline of major events that eventually led up to the passing of the legislation. Underlying ideational dimensions are then corroborated through the help of in-depth interviews conducted with the main actors involved in the legislative process.

The last chapter concludes the research by laying out features for a new theoretical paradigm on understanding public policy outcomes and policymaking process based on the concept of ideas. In light of the findings of this research, the chapter provides agenda for future research in public-policy theory building. It also introduces readers to a typology based on the origin of public policy as a descriptive tool to depict the essential features of public policy dynamics.

\section{6: CONCLUDING WORDS}

While examining the major approaches to public policy grounded in welfare economics and public choice theory, among others, Bobrow and Dryzek conclude that they do not fit well 
with political reality and are of limited value to policy sciences. ${ }^{80}$ Rossell, while introducing a framework for analysing policy alternatives, writes, "the mathematical side of policy analysis is often indicted as naïve because it is apolitical." ${ }^{81}$ Fischer argues, "Policy analysis and policy outcomes were infused with sticky problems of politics and social values [and] against this awareness the empiricist emphasis was naïve. ${ }^{82}$ There seems to be a consensus developing among scholars that the field of policy sciences require more intuitive approaches and perhaps the policy phenomenon cannot be studied with scientific methods and rigorous statistical techniques. $^{83}$

Ivana Đurić writes, "Public policy is a well-established field within Western political science research with an abundance of theoretical approaches and empirical studies focusing on various aspects of policy in developed countries...however, the applicability of these theoretical approaches and methodologies to the specific contexts of developing countries has been neglected." ${ }^{\prime 84}$ The social sciences have contributed a great deal to the understanding of why particular public policy decisions are made. What is missing, however, are more universal approaches to policy sciences that can examine public policy decision regardless of societal, political and socioeconomic conditions. This research is a step in this very direction.

\footnotetext{
${ }^{80}$ Bobrow, Davis B. and Dryzek, J., Policy Analysis by Design (Pittsburgh, PA: University of Pittsburgh Press, 1987)

${ }^{81}$ Rossell, Christine H., "Using Multiple Criteria to Evaluate Public Policies: The Case of School Desegregation," American Politics Quarterly, Vol. 21, No. 2 (1993): 157-8

${ }^{82}$ Fischer, F., 2003: 11

${ }^{83}$ Stewart, J., Hedge, David M. and Lester, James P, 2008: 13

${ }^{84}$ Đurić, I., "The New Institutionalism(s): A Framework for the Study of Public Policy in Postconflict and Post-communist Countries," Politička Misao, Vol. 48, No. 5 (2011): 85
} 



\section{THEORIES OF REGULATION AND REGIME TYPE}

\section{1: INTRODUCTION}

races of regulation, perhaps, can be studied as far back as the existence of
government. In the words of Tocqueville, government is defined here as, all
encompassing, a group of people having "regulating power over society."1

Regulation scholarship is generally blind to how such 'power' is acquired or retained. Indeed, regardless of regime type, regulation is as much a tenet of monarchy or dictatorship as it is of democracy or of their subsidiary forms. ${ }^{2}$ Variations in the theory and practice of regulation vis-à-vis the type of regime, though, are worthy of investigation. The focus here, however, is broader. The two main and contending set of theories of regulation, namely the public interest and private interest theories, are studied from the prism of countries that do not necessarily present facets of pluralist societies, i.e. the United States (US), or of wellestablished liberal democracies but, rather, fall into the political grey-zone. ${ }^{3}$

Before proceeding further, the next section first establishes the concept of political grey-zone. The paper then lays down some key considerations regarding existing literature on regulation

\footnotetext{
${ }^{1}$ Tocqueville, Alexis de, Journey to America (1831-1832) - Alexis de Tocqueville's travel diary of his visit to America; [trans.] George Lawrence, [ed.] J. P. Mayer (New Haven, CT: Yale University Press, 1960): p. 237

${ }^{2}$ For regime classification see: Sharma, S. and Sharma, S. K., Principles and Theory of Political Science (New Delhi: Atlantic Publishers \& Dist., 2000): pp. 406 - 433

${ }^{3}$ Carothers, T., "The End of the Transition Paradigm," (pp. 5 - 21) Journal of Democracy, Vol. 13, No. 1 (2002): p. 9
} 
to structure the succeeding discussion. This is followed by a section describing the two contending sets of economic theories of regulation, along with main criticism levelled against them, from their origin to the point of social regulation and deregulation movements of 1970s. Section IV recapitulates these movements followed by a section detailing reformulation of economic theories of regulation to adjust to this unpredicted and, therefore, unexplained shift in regulatory policies. In this section, economic theories of regulation, as they stand today, are seen through regime classification literature. Section VI points to a developing literature, primarily stemming from institutionalist theories, as an alternative microscope for investigating regulatory policies of countries of grey-zone. The last section sets the agenda for future research with some concluding words.

\section{2: POLITICAL GREY-ZONE}

Alvarez et al argue that valid and reliable classification is required for systematic study of issues concerning both the origins and consequences of political regimes. ${ }^{4}$ The subject of regime classification is not new to political thinkers and the earliest discussion on classification of political systems can be traced back to the Greek-era thinkers Aristotle and Plato. ${ }^{5}$ The subject of classification of political systems rekindled with the collapse of the Soviet Union in late 1980s and early 1990s and started receiving increased attention by political scientists. As Brownlee writes, from 1990 to 1994 the global number of electoral democracies rose $50 \%$ from 76 to 114 , as tallied by the Freedom House. ${ }^{6}$ Samuel Huntington,

\footnotetext{
${ }^{4}$ Alvarez, M., Cheibub, Jose A., Limongi, F., and Przeworski, A., "Classifying Political Regimes," Studies in Comparative International Development, Vol. 31, No. 2 (996): p. 3

${ }^{5}$ Johnson, Ollie A., "Pluralist Authoritarianism in Comparative Perspective: White Supremacy, Male Supremacy, and Regime Classification," in Georgia Anne Persons (ed.) Race and Ethnicity in Comparative Perspective (New Jersey: Transaction Publishers, 1999): p. 116

${ }^{6}$ Brownlee, J., "Portents of Pluralism: How Hybrid Regimes Affect Democratic Transaction," American Journal of Political Science, Vol. 53, No. 3 (2009): p. 517
} 
in his 1991 book, famously coined this surge as "Third Wave" of democratisation. ${ }^{7}$ As the direct consequence of the collapse of the Soviet Union and indirectly through the decline in Cold War Polarization, there was the expansion of democracy leading to transitions in military and one-party dictatorships. Haggard and Kaufman write that the Third Wave fostered considerable optimism among political circles and academia that "democracy is on the march and that underdevelopment and other structural factors would not impede its spread. ${ }^{\prime 8}$ Scholars treated these regimes as incomplete and transitional forms of democracy. ${ }^{9}$ This euphuism was, however, short-lived. In a famous article, "The End of the Transition Paradigm," Carothers criticized the assumption that whether movement from authoritarian rule would necessary lead to democracy. ${ }^{10}$ Gilbert and Mohseni write that while with the Third Wave of democratisation the number of regimes holding multiparty elections increased with the full adult franchise but "these democratic features appeared alongside the persistence of authoritarian forms of rule in many countries, [and therefore] posing significant challenges for typological classification." 11 In academic discussions, this variation resulted in producing a variety of labels including hybrid regime, semi democracy, virtual democracy, electoral democracy, pseudo democracy, illiberal democracy, semi authoritarianism and Freedom House's 'partly free' countries. ${ }^{12}$ This zone of indeterminacy, as Haggard and Kaufman would like to call it, where countries could neither be classified as democratic or outright authoritarian has given rise to a distinct theoretical counter current in political science since

\footnotetext{
${ }^{7}$ Huntington, Samuel P., The Third Wave: Democratization in Late Twentieth Century (Norman: University of Oklahoma Press, 1991)

${ }^{8}$ Haggard, S., and Kaufman, Robert R., "Democratization During the Third Wave," The Annual Review of Political Science, Vol. 19 (2016): p. 8.1

${ }^{9}$ Levitsky, S., and Way, Lucan A., "Elections Without Democracy: The Rise of Competitive Authoritarianism," Journal of Democracy, Vol. 13, No. 2 (2002): p. 51

${ }^{10}$ Carothers, T., 2002

${ }^{11}$ Gilbert, L., and Mohseni, P., "Beyond Authoritarianism: The Conceptualization of Hybrid Regimes," Studies in Comparative International Development, Vol. 46 (2011): p. 271

${ }^{12}$ Levitsky, S., and Way, Lucan A., 2002, p. 51
} 
the turn of the twenty-first century. ${ }^{13}$ Carothers has dubbed this a political grey-zone in which countries have some attributes of democratic political life, i.e. regular elections or a democratic constitution, yet they suffer from serious democratic deficits, i.e. poor representation of citizens' interests and persistently poor institutional performance by the state, and, therefore, fall somewhere between the two extremes of an outright dictatorship and well-established liberal democracy. ${ }^{14}$ Levitsky and Way also echo Carothers call to move beyond the transition paradigm. ${ }^{15}$ It is the contention in this Chapter that both sets of economic theories of regulation implicitly subscribe to pluralistic liberal democracies and are foremost the representation of US political dynamics. Therefore, they have questionable generality and could be of little service to a wide array of political regimes of grey-zone.

\section{3: KEY CONSIDERATIONS}

The concept of government intervention appears throughout in the work of political philosophy. However, Alfred Marshall first laid its theoretical foundations in late nineteenth century in his seminal work Principles of Economics. ${ }^{16}$ Marshall therein introduces the notion of external economies of production on a large scale what is now known as positive externalities and became theoretical basis for government intervention to correct market failure. ${ }^{17}$ It was nonetheless, the successor of Alfred Marshall -Arthur Cecil Pigou - who in his book The Economics of Welfare further develops the concept of externalities, and,

\footnotetext{
${ }^{13}$ Haggard, S., and Kaufman, Robert R., 2016, p. 8.8

${ }^{14}$ Carothers, T., 2002, p. 10

${ }^{15}$ Levitsky, S., and Way, Lucan A., 2002, p. 63

${ }^{16}$ Marshall, A., Principles of Economics (London: Macmillan and Co., Ltd., 1890)

${ }^{17}$ Groosman, B., "Pollution Tax," in (eds.) Boudewijn Bouckaert and Gerrit De Geest, Encyclopedia of Law \& Economics, Volume II. Civil Law and Economics (Cheltenham: Edward Elgar, 2000): p. 539
} 
arguably, credited with introducing the first formal theory of government regulation, which is known as public interest theory. ${ }^{18}$

Before public interest theory and, essentially, its critique in the form of private interest theories are discussed, it is important to underscore that regulation calls for a multidisciplinary approach to its evaluation from the perspectives of economics, political science, sociology, history, geography, psychology, management and social administration. Moran, perhaps, best narrates this multi- and cross-disciplinary nature of the study of regulation as “... a sort of intellectual brazier around which we can all gather to warm our hands and speak to each other, in a world of increasingly fragmented academic professionalism." ${ }^{19}$ On the contrary, regulation has been, by far the most, dominated by the application of economics scholarship for the most part of the twentieth century. It was only in early 1980s and thereafter that there is resurgence of political science's interest, and of other disciplines of social sciences, in the theory of regulation in the backdrop of the then movements toward deregulation and social regulation of US economy. ${ }^{20}$ Today, as Levi-Faur states, "few projects are more central to the social sciences than the study of regulation..." not to mention "the financial, ecological, legitimation and moral crisis of our time make regulatory issues even more central then ever before. ${ }^{21}$ The paper, therefore, attempts to draw in this plurality of conceptions from different disciplines to develop greater theoretical insights on the subject of regulation.

\footnotetext{
${ }^{18}$ Djankov, S., et al., "The Regulation of Entry," (pp. 1 - 37) The Quarterly Journal of Economics, Vol. 117, No. 1 (2000): p. 2

${ }^{19}$ Moran, M., "Understanding the Regulatory State," (pp. 391 - 413) British Journal of Political Science, Vol. 32, No. 2 (2000): p. 412

${ }^{20}$ Reagan, Michael D., “The Politics of Regulatory Reform,” (pp. 149 - 167) The Western Political Quarterly, Vol. 36, No 1 (1983): p. 149; Realizing the dominance of economics, National Science Foundation funded a conference in 1982 entitled Regulation and the Social Sciences in Reston, Virginia to encourage more direct research from other disciplines, see: Noll, Roger G., Regulatory Policy and the Social Sciences (California, University of California Press, 1985)

${ }^{21}$ Levi-Faur, D., "Regulation and Regulatory Governance," (pp. 3 - 21) in David Levi-Faur (ed.) Handbook on the Politics of Regulation (Cheltenham: Edward Elgar, 2011): p. 16
} 
Also, much of the theoretical debate has cantered on the "old-style economic regulation" which has typically focused on markets and rates. It was only by late 1970 s that there was realisation in some academic circles of a "new-style social regulation" which goes beyond market regulation, in a traditional sense of price and entry control mechanism, and affects the conditions under which goods and services are produced. ${ }^{22}$ Since the purpose of 'social regulation' has been markedly different from 'economic regulation' not only its results vary but the theoretical underpinnings between the two also differ. ${ }^{23}$ There are other offshoots to the study of regulation, i.e. regulation inside government, where literature is still in its embryonic stage but fast developing. ${ }^{24}$ Yet more, there are areas i.e. government regulation of mixed public/private firms, which have not even fully sprouted and only a benign interrogation exists of how to institute democratic regulation of such complex systems without giving in to the power of market forces or else falling back to 'statism' of one degree or another. ${ }^{25}$ We might be living in the "golden age of regulation," but, by no means, we have mastered the art of understanding regulatory politics. There are subject areas not even having come under the scrutiny of theorists while others require greater systematic and theoretical attention. $^{26}$

Lastly, even as basic as the subject matter what is regulation has been fiercely contested within and between disciplines. The term is employed for a range of discursive, theoretical

\footnotetext{
${ }^{22}$ Lilley III, W., and Miller, James C., "The New "Social Regulation"," (pp. 49 - 61) Public Interest, Vol. 47, Spring (1977): p. 53

${ }^{23}$ Friedman, Barry D., Regulation in the Regan-Bush Era: The Eruption of Presidential Influence (Pittsburgh: University of Pittsburgh Press, 1995): pp. 7 - 19

${ }^{24}$ James, O., "Regulation Inside Government: Public Interest Justification and Regulatory Failures," (pp. 327, 343) Public Administration, Vol. 78, No. 2 (2000): p. 327

${ }^{25}$ Sachs, I. "What State, What Markets, For What Development? The Social, Ecological and Economical Dimensions of Planning," (pp. 311 - 320) Social Indicators Research, Vol. 39, No. 3 (1996): p. 315

${ }^{26}$ Jacobs, Scott H., "The Gold Age of Regulation," CEPMLP Research Network, Vol. 7, Article 13 (2000)
} 
and analytical purposes, which carries different connotation for different disciplines, schoolsof-thought, research methods, and unique national and historical context. ${ }^{27}$ For instance, legal scholars see regulation as a legal instrument, but for institutionalists, it might be a constitutive element. For scholars of public administration, the term is a direct reference to governance, but for economists, it is a product sold by government and acquired by more influential interest groups. Even within disciplines, the term carries different meaning for different scholars. Kenneth Meier, a political scientist, sees regulation in broadest possible terms as "any attempt by the government to control the behaviour of citizen, corporations or sub-governments. ${ }^{, 28}$ Barry Friedman, though of the same discipline, looks regulation purely from the lens of a market-based intervention as being the "government control over certain action and decision by business managers. ${ }^{, 29}$ Julia Black does not see regulation to be a government's prerogative only or necessarily involving legal mechanisms and defines it as "a process involving the sustained and focused attempt to alter the behaviour of others according to identified purposes with the intention of producing a broadly identified outcome or outcomes... ${ }^{30}$ Broader definitions of regulation have been criticised on the account of being effectively encompassing everything, narrower concepts, on the other hand, are undermined on being one-dimensional. ${ }^{31}$ Economists usually distinguish between 'economic' and 'social' regulations, and have primarily focused on the explanation of the former. Such as the likes of Paul Joskow and Nancy Rose who define economic regulation as "direct legislation and

\footnotetext{
${ }^{27}$ See: Jordana, J. and Levi-Faur, D., "The Politics of Regulation in the Age of Governance," (pp. 1 28) in Jacint Jordana and David Levi-Faur (eds.) The Politics of Regulation: Institutions and Regulatory Reforms for the Age of Governance (Cheltenham: Edward Elgar, 2004)

${ }^{28}$ Meier, Kenneth J., Regulation: Politics, Bureaucracy and Economics (New York: St. Martin's Press, 1985): p. 1

${ }^{29}$ Friedman, Barry D., 1995: p. 7

${ }^{30}$ Black, J., "Regulatory Conversation," (pp. 163 - 196) Journal of Law and Society, Vol. 29, No. 1 (2002): pp. 170

${ }^{31}$ Vedung, E. "Policy Instruments: Typologies and Theories," (pp. 21 - 58) in Marie-Louise Bemelmans-Videc, Ray C. Rist, Evert Vedung (eds.) Carrots, Sticks, \& Sermons: Policy Instruments and their Evaluation, $4^{\text {th }}$ paperback edition (New Jersey: Transaction Publishers, 2007) p: 32
} 
administrative regulation of prices and entry into specific industries or markets." ${ }^{\text {,2 }}$ Anthony

Ogus, from the field of law, trying to amalgamate the conceptions of economics and law together, sees regulation as a "type of public law which implements collectivists goals, that is, by which the state seeks to direct or encourage behaviours which would not occur without such intervention." ${ }^{33}$ Others have attempted to provide a cross-disciplinary definition of the term as "employment of legal instruments for the implementation of social-economic policy objectives." 34 Philip Selznick's all-inclusive definition of regulation as "the sustained and focused control exercised by a public authority over activities valued by the community," which is considered seminal and has been widely quoted is today plagued with criticism as to what constitute 'control,' 'public authority,' 'values' and 'community. ${ }^{35}$ There are even cross-Atlantic differences as how regulation is conceived. In UK, a state described as an “audit society," regulation is defined as "arm's length oversight involving the setting or monitoring of standards, and based on some element of authority." 36 European Union considers regulation as one of five forms of laws, others being directives, decisions, recommendations and opinions, applicable and obligatory in all member states. In the nutshell, questions as to who is regulating; does regulation contain intentional and goaloriented attempt; what is that is being regulated; what particular arrangements and techniques

\footnotetext{
32 Joskow, Paul L. and Rose, Nancy L., "The Effects of Economic Regulation," (pp. 1450 - 1506) in Richard Schmalensee and Robert D. Willig (eds.) Handbook of Industrial Organization, Vol. II (North-Holland, Amsterdam1989): p. 1450

${ }^{33}$ Ogus, A., "Evaluating Alternative Regulatory Regimes: The Contribution of Law and Economics," (pp. 223 - 229) Geoforum, Vol. 30, No. 3 (1999): p. 223

${ }^{34}$ Den Hertog, J., "General Theories of Regulation," in B. Bouckaert and G. de Geest (eds.), Encyclopedia of Law and Economics: Volume III. The Regulation of Contracts (Cheltenham: Edward Elgar, 2000): p. 223

${ }^{35}$ See: Baldwin, R., Cave, M. and Lodge, M., "Introduction: Regulation - The Field and the Developing Agenda," (pp. 3 - 16) in Robert Baldwin, Martin Cave and Martina Lodge (eds.) The Oxford Handbook of Regulation (New York: Oxford University Press, 2010): p. 12; and Selznick, P., "Focusing Organizational Research on Regulation," (pp. 363 - 368) in Roger G. Noll (ed.) Regulatory Policy and the Social Sciences (Berkeley: University of California Press, 1985): p. 363;

${ }^{36}$ See: Power, M., The Audit Society: Ritual of Verification (Oxford: Oxford University Press, 1997); Hood, C., et al., Regulation Inside Government: Waste-Watchers, Quality Police and Sleaze-Busters (Oxford: Oxford University Press, 1999): p. 21
} 
are assumed for regulation; what, if any, outcomes are foreseen as the result of regulation; and at what level is the regulation being carried out; will all have implications on how one conceives and define regulation. ${ }^{37}$ The attempt here is not to redefine 'regulation' or to offer critique of the existing set of definitions but to highlight the wide array of comprehensions and conceptions the term has stimulated. However, in order to set structure to the succeeding analysis, regulation is considered as a subset of public policy that conform with the definition of Robert Dye who considers public policy as "whatever governments choose to do or not to do." ${ }^{38}$ By adapting the conception of Baldwin, Scott and Hood, 'regulation' itself is seen through different characteristics as "a specific set of commands," which have "deliberate state intent" and that pertains to "all forms of social control or influence." 39

\section{4: ECONOMIC THEORIES OF REGULATION:}

The twentieth century, for the better part, has been dominated by two contending theories of regulation emanating from the discipline of economics. Until the early 1960 s, the public interest theory was the prevailing theory of government regulation, which provided normative rationale as a positive theory to how people and institutions should behave in case of market failures. In 1970s, an alternative to orthodox, normative 'public interest' explanation, started building-up based on positive economics to understand 'why' government regulation occurs, and became strongly critical of normative justifications for government interventions. The following discussion describes the accounts provided by these

\footnotetext{
${ }^{37}$ For a detailed discussion on the concept of regulation, see: Black, J., "Critical Reflections on Regulation," Australian Journal of Legal Philosophy, Vol. 27 (2002): pp. 1 - 35

${ }^{38}$ Dye, R., Understanding Public policy (Englewood Cliffs, NJ: Prentice Hall, 1978): p. 3

${ }^{39}$ See: Baldwin, R., Scott, C., and Hood, C., A Reader on Regulation (Oxford: Oxford University Press, 1998): Ch. 1
} 
two opposing theories together with most of the general criticism levelled against them to set the foundation for succeeding sections.

\subsection{1: PUBLIC INTEREST THEORY}

Early strands of economic theory of public regulation are embedded in the discipline of welfare economics. Some would trace back the roots of welfare economic discipline to the design of the concept of 'Pareto optimality' as introduced by Vilfredo Pareto. ${ }^{40}$ Nonetheless, it was Pigou who, in The Economics of Welfare, develops the concept of externalities at considerable length and justifies government intervention in case of their existence. Pigou writes, "When the practical issue is raised whether a particular class of enterprise could, with greater advantage to the national dividend, be publically controlled...it will be necessary... with which whatever regulation the public interest may require can be applied under them." ${ }^{41}$ Accordingly, public interest theory holds that government regulations are an instrument for overcoming market failures of imperfect competition, unbalanced market operation, missing markets and undesirable market results. ${ }^{42}$ Importantly, as Baldwin and Cave consider, these are often the "technical justifications for regulating that may be given by a government that is assumed to be acting in pursuit of the public interest." 43 They list several rationales for government regulation, most of which could be lumped into the justifications of 'market failure' or 'market absence' in accordance with the public interest. ${ }^{44}$ In general terms, the theory explains that regulation seeks the protection and benefit of the public at

\footnotetext{
${ }^{40}$ Hägg, P. Göran T., "Theories on the Economics of Regulation: A Survey of the Literature from a European Perspective," (pp. 337 - 370) European Journal of Law and Economics, Vol. 4, No. 4 (1997): p. 339

${ }^{41}$ Pigou, Arthur, C., The Economics of Welfare (4 ${ }^{\text {th }}$ ed.) (London: Macmillan, 1932): p. 109

${ }^{42}$ Den Hertog, J., 2000: p. 225; the public interest theory has also been referred to as normative analysis as a positive theory.

${ }^{43}$ Baldwin, R. and Cave, M., Understanding Regulation: Theory, Strategy and Practice (New York: Oxford University Press, 1999): p. 9

${ }^{44}$ Ibid, pp. $9-17$
} 
large. Until the beginning of 1960 s, as Aranson explains, the account provided by the public interest theory of how government might regulate private economic activities to improve the welfare of its citizens formed an "elegant and well-articulated model." In next ten years, however, the theory came under intense criticism from all sorts of directions, i.e. political, economic and legal. By mid-1970s the original model could provide little explanation of government regulatory activities. ${ }^{45}$

One of the basic criticisms to the theory stems from its notion that there will be full agreement on the conception of 'public interest' among the effected parties as articulated by the regulator. There might be the case, as usually is, that there are more than one conceptions of public interest competing with each other, which the theory fails to take into account. ${ }^{46}$ The public interest theory is also criticised on the grounds that it inherently conceives a benevolent regulator interested only in pursuing the welfare of its citizen with required expertise, competency and efficiency to yield public interest ends, which could all as well be otherwise. ${ }^{47}$ Ronald Coase, in his seminal piece, contended the standard course of actions in case of externalities, as advocated by Pigou in The Economics of Welfare, which is either based on litigation or government regulation, as not only inappropriate but also leading "to results which are not necessarily, or even usually, desirable." ${ }^{, 48}$ In the case of negative externalities, Coase argues that mutually satisfactory bargain between those causing externality and those negatively affected by it is more optimal solution than either through litigation or government regulation. ${ }^{49}$ The most formidable criticisms to the public interest

\footnotetext{
${ }^{45}$ Aranson, Peter H., "Theories of Economic Regulation: From Clarity to Confusion," (pp. 247 - 286) Journal of Law \& Politics, Vol. 6, No. 1 (1989-1990): p. 282-3

${ }^{46}$ Eisner, Marc A., Worsham, J. and Ringquist, Evan J. Contemporary Regulatory Policy, $2^{\text {nd }}$ ed. (Boulder, CO: Lynne Rienner, 2006): p. 6

${ }^{47}$ Baldwin, R. and Cave, M., 1999: p. 20

${ }^{48}$ Coase, Ronald, H., "The Problem of Social Cost," (pp. 1 - 44) Journal of Law and Economics, Vol. 3 (1960): p. 2

${ }^{49}$ Ibid, pp. $1-44$
} 
theory, though, had started brewing-up much earlier. In an article written by Samuel P. Huntington in 1952 on assessing the effectiveness of one of the oldest regulatory bodies created in the US concerned with transportation - the Interstate Commerce Commission - he arrives at a conclusion that the Commission is serving the interests of the rail carriers instead of representing the public interest. ${ }^{50}$ Similar assessments of regulatory bodies and regulatory interventions culminated in early 1970s into a new set of theories, originating from the Chicago School of Economics, based on the concept of regulatory capture. ${ }^{51}$ One of the earliest accounts on the issue of capture, of regulatory institutions by regulated industries, however, came in 1955 from Bernstein. ${ }^{52}$ Bernstein, while studying the independent regulatory commission in US, presented a theory suggesting that regulatory agencies go through an evolutionary lifecycle, when mature, to a point where they protect the industry they are supposed to regulate on behalf of the community. ${ }^{53}$ When public regulation is supplied in response to the demand of particular pressure group having interest in the outcome of regulation was thus terms as capture theory. ${ }^{54}$ For many, especially those who subscribe to the Chicago School, the public interest theory is beset by a myriad of theoretical and practical problems, even to a point where it is assumed to be a mere description rather than a theory. ${ }^{55}$ Viscusi et al. maintains that since the theory does not generate the testable prediction rather assumes that regulation occur to correct a market failure makes it more

\footnotetext{
${ }^{50}$ Huntington, Samuel P., "The Marasmus of the ICC: The Commission, the Railroads, and the Public Interest," (pp. 467 - 509) The Yale Law Journal, Vol. 61, No. 4 (1952): p. 507

${ }^{51}$ See: Stigler, George J., "The Theory of Economic Regulation," The Bell Journal of Economics and Management Science, Vol. 2, No. 1 (1971): pp. 3 - 21

${ }_{52}$ Moran, M., 2000: p. 393

${ }^{53}$ See: Bernstein, M., Regulating Business by Independent Commission (Princeton, NJ: Princeton University Press, 1955)

${ }^{54} \mathrm{Hägg}, 1997$ : p. 343; In some academic works 'capture theory' is treated as a distinct phase in the theoretical history of regulation, as it originated from political science discipline, falling between public and private interest conceptions of government regulation. Here, it is considered as one of the first building blocks of the theories that emanated from the Chicago School of Economics.

${ }^{55}$ Posner, Richard A., The Economics of Justice, (Cambridge, MA: Harvard University Press, 1983) p. 104
} 
likely a hypotheses or statements about empirical regularities. ${ }^{56}$ Hantke-Domas makes a similar assertion after reviewing the history of the concept of public interest that the theory is rather a concept in the fields of law and politics to support regulation in philosophical and political terms. ${ }^{57} \mathrm{~A}$ foundation for a new set of theories, based on neoclassical economic ideologies, was effectively set from the rubbles of the public interest theory.

\subsection{2: PRIVATE INTEREST THEORIES}

Three economists of Chicago School, namely George Stigler, Richard Posner and Sam Peltzman, are attributed to this branch of economic interpretation of government regulation which goes under several names i.e. economic, Chicago, private interest, public choice, special interest, and capture. In 1971, Stigler presented his theory of regulation to which he himself named as theory of economic regulation and made a central proposition that "as a rule, regulation is acquired by the industry and is designed and operated primarily for its benefit." Stigler conjectures that since the state has the power to coerce, it provides possibilities to an industry to utilise this to increase its profitability through provision of direct subsidies, control over entry by new rivals, affecting substitutes and complements as a means of protecting or expanding the market for their goods and price-fixing. In return, the industry, which seeks regulation, must be prepared to pay with votes and resources to the political party. He arrives at the conclusion that regulation is not directed at the correction of market failures, but at setting up income transfers in favour of the industries in exchange for political support. ${ }^{58}$ In a 1974 article, Richard Posner tabled criticism on both the accounts

\footnotetext{
${ }^{56}$ Viscusi, W. K, Harrington, Joseph E. and Vernon, John M., Economics of Regulation and Antitrust (Cambridge, MA: MIT Press, 2005): pp. $375-378$

${ }^{57}$ Hantke-Domas, M., "The Public Interest Theory of Regulation: Non-Existence or Misinterpretation?” (pp. 165 - 194) European Journal of Law and Economics, Vol. 15, No. 2 (2003): p. 188

${ }^{58}$ See: Stigler, George J. 1971: pp. 3 - 21
} 
provided by public and private interest theories where, he contested, that former lacks academic rigor of a theory and is actually more of a hypothesis but held a more optimistic view of the latter to be able to be verified empirically. ${ }^{59}$ Posner, through his criticism, extended Stigler's interpretation of economic regulation and highlighted that "much regulation seems subservient to special-interest customer groups [not the industry alone], an evidence enough of interest groups effectively influencing public policy for their vested benefits. ${ }^{60}$ Posner explained that the coercive power of government to be able to apply economic regulation could be viewed as a product in the economic sphere and whose allocations is governed by the same laws of supply and demand as of any other market product. Furthermore, the product will be supplied to those individuals or groups who value it the most. ${ }^{61}$ In an earlier article written in the same issue in which Stigler had presented his theory of economic regulation, Posner observes that in many cases regulation advantage certain consumer groups, such as in the case of operating rail transport to destinations which are economically unviable, and this phenomenon of internal- or cross-subsidisation could not be explained by Stigler's interpretation of economic regulation. ${ }^{62}$ Posner's contribution was invaluable as it paved the way for another Chicago-based economists Sam Peltzman to further refine Stigler's theory of economic regulation.

In 1976, Peltzman made further advancements to Stigler's theory, which is known as a multiinterest approach to economics of regulation. Peltzman, as oppose to Stigler's notion, notes that regulatory agencies do not exclusively serve a single economic interest rather there are

\footnotetext{
${ }^{59}$ Posner, Richard A., "Theories of Economic Regulation," The Bell Journal of Economics and Management Science, Vol. 5, No. 2 (1974): pp. 335 - 358

${ }^{60}$ Ibid, p. 352

${ }^{61}$ Ibid, p. 344

${ }^{62}$ Hertog, 1999, p.238; also see: Posner, Richard A., "Taxation by Regulation," The Bell Journal of Economics and Management Science, Vol. 2, No. 1 (1971): pp. 22 - 50
} 
contending interests which seek to exercise leverage in their pursuit of wealth. ${ }^{63}$ He based his argument on the view that political representatives will distribute more of the good [regulation] to those whose effective demand is highest and this will be to a small group with large per capita stake as appose to a large group [consumers] having more diffused interests. He further explains that "it is not enough for the successful group to recognise its interests; it must organise to translate this interest into support for the politician who will implement it." Peltzman noted that there are diminishing returns associated with both group's size and wealth transfers in politics. Larger political coalitions are counterproductive as they reduce the per capita transfer of wealth but larger wealth transfers also provoke public opposition that is difficult to overcome. ${ }^{65}$ Peltzman, through his model, comes to a conclusion that arbitrating politicians, in maximizing their chance to be elected, will distribute favours and disfavours among voters and pressure groups so that not one interest group will gain all the privileges they demand. Therefore, "every identifiable group," in pursuit of wealth, "contains winners and losers," hence not only well-organised industries but also other groups are expected to win favours on the political market. ${ }^{66}$ Even though, Peltzman had extended Stigler's model by adding more players into the economic interpretation of regulation, it was criticised for not fully capturing the regulatory politics since not just politicians but many different actors could be regulators i.e. judges and bureaucrats. Any equilibrium, therefore, should be a balance between all the concerned interest groups including those who act as regulators. ${ }^{67}$ However, theories of regulation that focused on the agencies, rather than the electoral process and the incentives operating on politicians, most also predicted outcomes

\footnotetext{
${ }^{63}$ Peltzman, S., "Toward a More General Theory of Regulation," Journal of Law and Economics, Vol. 19, No. 2 (1976): pp. $211-240$

${ }^{64}$ Ibid, p. 213

${ }^{65}$ Eisner, Marc A., Worsham, J. and Ringquist, Evan J., 2006: p. 9

${ }^{66}$ Peltzman, S., 1976, p. 240

${ }^{67}$ O'toole, James K., "The Economics of the Implementation of Social Policy: Search for the Missing Link," (pp. 115 - 130) The Social Science Journal, Vol. 26, No. 2 (1989): p. 117
} 
favourable to organised interest. ${ }^{68}$ For Joskow and Noll the essence of Stigler-Posner-

Peltzman theory is that "regulation is a device for transferring income to well-organised

groups if the group will return the favour with votes and contributions to

politicians...[who]..."will use their power to transfer income from those with less political

power to those with more. ${ }^{, 69}$ But as soon as the model appeared solid and wholly explanatory

of regulatory decisions, it started to unravel. There was critique levelled from several fronts.

For the theory to have worked, it required the process to work in an exact manner, interest

groups to have strong impact on the outcome of elections and ability to sufficiently

constraining the legislator with the threat of withdrawing support as well as it needs

regulators to be under control of the legislator so the regulation is implemented the way it is

desired. The theory is also criticised of ignoring legislator's own 'ideology' as to what should be the best or preferred states of the world, which could be in conflict with the desires of the interest groups. The theory also does not take into account the judiciary, which has shown, in the case of the United States, to be a key player in the regulatory process. ${ }^{70}$ But the biggest challenge to the theory came with the advent of political movements, in the United States, toward deregulation and new style social-regulation, both the phenomena which it could have not predicted or explained. Aran son expresses this theoretical predicament, "we now remain with two battered theories [referring to public interest and private interest theories], each of doubtful generality. The second helped to demolish the first, but then the emerging political implications of the second in turn helped to demolish that theory too." ${ }^{, 71}$ By late 1970s and in early 1980s, amidst the scholarly chaos, there was a general recognition that a lot less is known about government regulation than is sometimes thought.

\footnotetext{
${ }^{68}$ Joskow, Paul L. and Noll, Roger G., "Regulation in Theory and Practice: An Overview," (pp. 1 78) in Gary Fromm (ed.) Studies in Public Regulation (Cambridge, MA: The MIT Press, 1981): p. 37

${ }^{69}$ Ibid, p. 36

${ }^{70}$ Viscusi, W. K., Harrington, Joseph, E. Vernon, John M., 2005, pp. 390 - 391

${ }^{71}$ Aranson, Peter H., 1989-90, p. 284
} 


\section{5: SOCIAL REGULATION AND DEREGULATION MOVEMENTS}

Social regulation is inherently different from economic regulation as it is intended for not just one industry but spread across a range of economic activities, e.g. occupational health and safety regulations, making capture, in its classical sense, inapplicable. Social regulation defies one-to-one intimate relationship between the regulated industry and regulatory agency, as it was the case in the old-style economic regulation and carries little sympathy for the health of the firm. Moreover, social regulation was more likely to be thrust upon industry than being established with their approval and encouragement as it imposes heavy costs of compliance. Social regulation goes beyond mitigating between the seller and the buyer, unlike economic regulation, and is concerned with other parties, such as employees, thirdparty victims of malfunctions or accidents or members of general public who may be subjected to negative externalities. Another difference is of public commitment, which was relegated in the old-style economic regulation due to high cost of organisation, coordination and low per capita stake. But social regulation enjoys generally widespread public support. ${ }^{72}$ Importantly, social regulations have always featured throughout the history of regulation; the reasons they were set on the pedestal during the 1970s are varying. It is believed that as the quality-of-life issues became more salient, social regulation became dominant after the 1960s. ${ }^{73}$ Yandle and Young argue that that it was more due to the underlying economic forces. They maintain that it was, firstly, due to the restructuring of the US economy from heavily tilted towards production industries to service industries. Secondly, out of economic depression, many companies started diversifying their product lines while succumbing to

\footnotetext{
${ }^{72}$ See: Eisner, Marc A., Worsham, J. and Ringquist, Evan J., 2006: p. 1 - 18; and Friedman, Barry D., 1995: p. 7 - 19

${ }^{73}$ Ibid, p.3
} 
large-scale mergers and in the process establishing conglomerates, and so it became difficult to regulate on economic lines than on function-lines. For them, the growth of social regulation, therefore, was a direct response to the increase in the demand for solutions of market failures. ${ }^{74}$ Nonetheless, the 1970 s is marked with the advent of a new wave of social regulation and none of the existing theories of regulation could explain this apparent shift. ${ }^{75}$

At around the same time when social regulations were gaining dominance in academic and political spheres, another phenomenon was taking shape, though much fierce in its intensity, of widespread deregulation of economic activities once heavily regulated. It was ironic as the free-market protagonists, led by Chicago School of Economics, had partly helped instigating this momentous change but in the process, unwittingly, immolated their established conception of economic regulation. Derthick and Qurik describe this, almost sudden, policy shift as deregulation transforming "from a lonely cause with poor political prospects into a buzzword and bandwagon. Once coined - it first appeared as an entry in the New York Times index in 1976 - the term entered swiftly into common and often gratuitous usage in Washington." ${ }^{, 76}$ By giving example of the airline industry of 1970s in the US where intercity routes were served, at most, by one, two or three carriers, Derthick and Qurik make a case that deregulation effectively lowered many of the barriers to entry and opened up the industry for a number small carriers which were not only able to sustain their businesses but made considerable profits, at the expense of large firms. They sight similar examples of the shippers of trucking freight and subscribers of telephone services. ${ }^{77}$ Efforts to deregulate

\footnotetext{
${ }^{74}$ See: Yandle, B. and Young, E. "Regulating the Function, Not the Industry," Public Choice, Vol. 51 (1986): pp. $59-70$

${ }^{75}$ Ibid, p. 59

${ }^{76}$ Derthick, M., and Quirk, Paul J., The Politics of Deregulation (Washington D.C.: The Brookings Institution, 1985) p. 53

${ }^{77}$ Ibid, pp. $1-4$
} 
industries in 1970s and 1980s were hard to square with the idea that incumbent firms are controlling regulatory policy in order to maintain entry barriers to new competitors. ${ }^{78}$

Social regulation and deregulation movements, in a way, proved to be a watershed for regulation studies as scholars sought answers from a range of perspectives moving beyond their traditional bipolar conceptions. Some, though, considered deregulation movement of late 1970 s and early 1980 s as a rare occurrence, "a temporary policy aberration rather than as an effort with any lasting impact," and contended that by mid-1980s, regulatory policy returned to the same patterns as in earlier administrations [of the US]. ${ }^{79}$ Still, those who subscribed to the Chicago School of Economics looked for answers for these new phenomena within their established conceptions of government regulations. ${ }^{80}$ There were others who attempted to plug the gaps, one at a time, highlighted in the Chicago theory of regulation. ${ }^{81}$

As economic theories of regulation had little to say about the social regulations, its key methodological assumptions were widely adopted among public choice scholars who delved into the impetus behind such regulations which impose cost on the regulated parties and where public, provided with diffused benefits, have few incentives to mobilise on behalf of

\footnotetext{
${ }^{78}$ Carrigan, C. and Coglianese, C., "The Politics of Regulation: From New Institutionalism to New Governance," (pp. 107 129) The Annual Review of Political Science, Vol. 14, No. 1 (2011): p. 109

${ }^{79}$ See: Viscusi, W. K., DeMuth, C., and Burnley, J., "Health and Safety Regulation," (pp. $453-518$ ) in Martin Feldstein (ed.) American Economic Policy in 1980s (Chicago: The University of Chicago Press, 1994) p. 501 - 502; for critical analysis of deregulation period also see: Rose-Ackerman, S., "Deregulation and Reregulation: Rhetoric and Reality," Journal of Law \& Politics, Vol. 6, No. 2 (1990): pp. $287-309$

${ }^{80}$ See: Peltzman, S., "The Economic Theory of Regulation after a Decade of Deregulation," Brookings Papers on Economic Activity. Microeconomics, Vol. 1989 (1989): pp. 1 - 59; also see: Keeler, Theodore, E., "Theories of Regulation and the Deregulation Movement," Public Choice, Vol. 44, No. 1 (1984): pp. $103-145$

${ }^{81}$ For instance Pablo T. Spiller expands the self-interest theory of regulation to account for the potential agency problems between Congress and it regulators, a missing link in the Chicago theory of regulation: Spiller, Pablo T., "Politicians, Interest Groups and Regulators: A Multiple-Principals Agency Theory of Regulation, or Let Them be Bribed," Journal of Law and Economics, Vol. 33, No. 1 (1990): pp. $65-101$
} 
the regulation. For them, it was not the benevolence of the legislation rather his self-interest and the incentive to protect those self-interests which leads to such social regulations as the result of public's awareness and voting participation on such issues are high. ${ }^{82}$ Peltzman, in his 1986 article, made the case that "on social policy issues (abortion, school prayer, and so on), where the wealth stakes are unclear, did ideology play a prominent role [being a republican or democrat $]^{\prime 83}$ One reflection of the impact social regulation and deregulation movements had on neoclassical economists could, perhaps, best be observed in Gordon Tullock words, one of the flag-bearers among public choice theorists, who could not help but to call his fellow scholars to "not totally ignore public interest or public interest voting," in their work. ${ }^{84}$

Conversely, the deregulation and social regulation movements rejuvenated the proponents of public interest theory who held issues of governance to be responsible for capture. They agreed that regulation restraints and restricts, imposes costs and may not work in achieving its objective but argued that it does not imply that it is not essential or potentially beneficial. They maintained that capture is the result of badly designed or effective resistance, or both. ${ }^{85}$ The likes of Gary Becker, on the other hand, tried to revolutionise the original Chicago-based model and worked to bring the two opposing theoretical conceptions of public and private interests of government regulation more in agreement with each other. This branch focused

\footnotetext{
${ }^{82}$ Becker, G., "The Public Interest Hypothesis Revisited: A New Test of Peltzman's Theory of Regulation," (pp. 223 - 234 Public Choice, Vol. 49, No. 3 (1986): 230

${ }^{83}$ Peltzman, S., "Constituent Interest and Congressional Voting," (pp. 181 - 210) Journal of Law and Economics, Vol. 27, No. 1 (1984): p. 210

${ }^{84}$ Tullock, G., "A (Partial) Rehabilitation of the Public Interest," (pp. 89 - 99) Public Choice, Vol. 42, No. 1 (1984): p. 98

${ }^{85}$ Clarke, M., Regulation: The Social Control of Business between Law and Politics (New York:

Palgrave Macmillan, 1999): p. 27
} 
on competition between interest groups instead of modelling it on a legislator or regulator choosing regulatory policy so as to maximise political support. ${ }^{86}$

Others urged to take a completely new line of explanation to "situate regulation in the larger political institutional network of relationships," as to how they "shape the patterns of governmental actions." ${ }^{87}$ Joskow and Noll, for instance, make this assertion that future direction for research should involve the utilisation of new theoretical and empirical techniques and change in emphasis with application of models of political and organisation processes. $^{88}$

Another escape-route from the cul-de-sac of the American regulatory state, as Moran puts it, was to abandon the quest of theoretical explanations of regulation and deregulation altogether and focus on reconfiguration of the substantive content of regulation to achieve publicinterest ends. ${ }^{89}$ John Braithwaite is particularly associated for taking this route to go beyond the debate of regulation and deregulation and look into the aspects of effective regulation or 'responsive regulation' and, more broadly, governance issues. ${ }^{90}$ As the result, foundations for new theoretical paradigms were set, while well-established conceptions forced to go through an overhaul to adjust to emerging realities.

\footnotetext{
${ }^{86}$ Viscusi, W. K., Harrington, Joseph E. and Vernon, John M., 2005, p. 385

${ }^{87}$ Eisner, Marc A., Worsham, J. and Ringquist, Evan J., 2006: p. 17

${ }^{88}$ Joskow, Paul L. and Noll, Roger G., 1981: p. 58

${ }^{89}$ Moran, M., 2002, p. 396

${ }^{90}$ Braithwaite, J., Crime, Shame and Reintegration (Cambridge, Cambridge University Press, 1989)
} 


\section{6: REFORMULATION OF ECONOMIC THEORIES OF REGULATION}

\subsection{1: FROM PRIVATE TO INTEREST-GROUP THEORIES}

Two important contributions were made to the theories originating from the Chicago School, one from within which further develops the existing conception and the other transpiring through its criticism from the Virginia School. The former is attributed to Garry Becker, a Chicago economist, who presented a theory, also called modified special interest theory, of the political redistribution of income and of other public policies that builds on competition among pressure groups for political favours as oppose to the existing theoretical build-up which suggested it to be determined by the efforts of individuals and groups to further their own interests. ${ }^{91}$ In Stigler, Posner and Peltzman conception the legislator or the regulator choose regulatory policy to maximise political support. In Becker's model, on the contrary, the "political equilibrium depends on the efficiency of each group in producing pressure, the effect of additional pressure on their influence, the number of persons in different groups and the deadweight costs of taxes and subsidies." Becker makes a case that "policies that raise efficiency are likely to win out in the competition because they produce gains rather than deadweight costs," and therefore this view unifies with the public interest notion that "governments correct market failures with the view that they favour the politically powerful by showing that both are produced by competition among pressure groups for political favours." 92 Becker's results show that regulatory measures causing social costs discourage the political power of benefited groups and encourage the power of those groups whose welfare has been harmed. Policies that raise efficiency are likely to win out in the

\footnotetext{
${ }^{91}$ Becker uses the term 'pressure groups' and 'interest groups' in the same sense and interchangeably. See: Becker, Gary S., "A Theory of Competition among Pressure Groups for Political Influence," The Quarterly Journal of Economics, Vol. 98, No. 3 (1983): pp. 372 - 400

${ }^{92}$ Ibid, p. 385
} 
competition between equally powerful pressure groups and those which benefits all is opposed by none and may be supported by some pressure groups. ${ }^{93}$ As Hertog summarises, Backer's model shows that government regulations are more likely to results out of market failures as the welfare gain by consumers is larger than the loss of producers in monopolistic industries as appose to in competitive markets. This implication brings the model closer to the public interest theory of regulation but still implying that regulation is dependent on the relative efficiency of pressure groups in exerting political pressure. ${ }^{94}$

The second stream of criticism came from the Virginia School of Public Policy based on the concept of 'rent seeking.' Though, Anne Krueger had first coined the term 'rent seeking' in her 1974 article, it was Gordon Tullock who had originally introduced the concept in $1967 . .^{95}$ Tullock paper "The Welfare Costs of Tariffs, Monopolies and Theft," in which he introduces the concept, remained largely unknown for the better part of a decade as it was published in a relatively obscure, new journal. As Krueger's paper was published in a major journal, in Tullock's own word "speeded up the process of dissemination of the basic idea within the economics profession." 96 The concept of 'rent seeking' originates from Arnold Harberger's classical text published in 1954 in which he looks at the welfare effects of resource misallocations due to monopoly, now known as Harberger's Triangle. Accordingly, up till late 1960 s, the social cost of monopoly was attributed to the deadweight loss triangle (measured through supply and demand graph), which shows the loss of consumers' surplus to

\footnotetext{
${ }^{93}$ Hägg, 1997: p. 345

${ }^{94}$ Den Hertog, J., 2000: p. 240

${ }^{95}$ See: Krueger, Anne O., "The Political Economy of the Rent Seeking Society," American Economic Review, Vol. 64, No. 3 (1974): pp. 291 - 303 and Tullock, G., "The Welfare Costs of Tariffs, Monopolies and Theft," Western Economic Journal, Vol. 5, No. 3 (1967): pp. 224 - 232

${ }^{96}$ Tullock, G., "The Fundamentals of Rent-Seeking," The Locke Luminary, Vol. 1, No. 2 (1998): Part 2
} 
those excluded from the market by the rise in price above the competitive level. ${ }^{97}$ This view constituted only the transfer of welfare to the monopolists but did not reflect any loss of welfare. Tullock builds on the argument that the resource costs, i.e. cost of lobbying, of individuals and groups devoted to the pursuit of monopoly rights are the resources wasted and society as a whole is worse off. As Robert Tollison explains, the Virginian School "incorporates the behaviour of government actors into economic theory, and it pushes... beyond the Pigovian fantasy that the market is guided by private interest and government is guided by public interest," but rely on the hypothesis that "individuals [including politician] seek to promote their self-interest in any given situation," whether they are behaving in a market or nonmarket context. ${ }^{98}$ The original 'rent seeking' model has been further advanced into rent extraction and rent creation in the economic theory of regulation. ${ }^{99}$ Accordingly, rents are not only sought but are also extracted, through means of threat or coercion, from the private sector by the regulator where the former pays significant sums to induce the latter not to impose cost. ${ }^{100}$ As Montanye further elaborates, "every rent created by state action is an expropriation from one group of faction for the benefit of another, and every successful rent-seeking episode creates and opportunity for future rent extraction. ${ }^{101}$ However, Virginia School has primarily focused on the issues of inefficiencies of regulation and is more of an extension to theories emanating from the Chicago School. ${ }^{102}$ Tollison perhaps best describes this when he compares the work of the two Schools "the interest-

\footnotetext{
${ }^{97}$ Harberger, A., "Monopoly and Resource Allocation," The American Economic Review, Vol. 44, No. 2 (1954): pp. $77-87$

${ }^{98}$ Tollison, Robert D., "Public Choice and Antitrust," (pp. 905 - 915) Cato Journal, Vol. 4, No. 3 (1985): p. 907; for a concise survey of the standpoint of public choice theorists to the theory and practice of antitrust law enforcement see: Shughart II, William F. and McChesney, Fred S., "Public Choice Theory and Antitrust Policy," Public Choice, Vol. 142, No. 3 (2010): pp. 385 - 406

${ }^{99}$ See for instance: McChesney, Fred S., "Rent Extraction and Rent Creation in the Economic Theory of Regulation," The Journal of Legal Studies, Vol. 16, No. 1 (1987): pp. 101 - 118

${ }^{100}$ Ibid, p. 118

${ }^{101}$ Montanye, James A., "On Rent Thinking and the Corruption of Republican Government," (pp. 519 - 535) The Independent Review, Vol. 7, No. 4 (2003): p. 520

${ }^{102}$ Den Hertog, J., 2000: p. 244
} 
group theory of government is about lobbying, and the theory of rent-seeking is about the costs of lobbying." ${ }^{103}$ To sum it, private interest theories are based on flimsy assumptions that politicians exclusively act out of self-interest and are motivated primarily by the goal of re-election. Furthermore, their policies are the result of affected groupings to organise collectively around common interests in receiving benefits. It implies that "government is no more than a conduit for political pressure; a source of inexorable reallocation towards the politically powerful."104

As Steven Croley rightly notes that the theories of regulation are all in one way or another outgrowths of the traditional pluralist theory of politics. ${ }^{105}$ Pluralism, in its contemporary sense, defines democracy as a form of stable and institutionalised political competition in which "organised interests strive to control government through taking part in electoral contests and/ or strive to influence the policies a government adopts, and in either case each of the competing interests has some reasonable chance of success in the contest for office or influence." 106 Importantly, Stigler's economic theory of regulation largely disregards pluralistic vision of regulatory decision-making and treats regulatory policies to be demanded and supplied according to the same basic principles governing the demand and supply of ordinary economic goods. Pluralism starts reflecting more vividly in the work of Chicago School economists with the benign criticism of Posner of Stigler's theory and takes firm roots in the work of Peltzman and Becker. Croley highlights this transformation from the work of

\footnotetext{
${ }^{103}$ Tollison, Robert D., "The Interest-Group Theory of Government: Problems and Prospects," (pp. 465 - 472) KYKLOS, Vol. 54, No. 2/3 (2001): p. 470; for a comprehensive discussion on the theory of rent seeking see: Rowley, Charles K., Tollison, Robert D. and Tullock, G., The Political Economy of Rent Seeking (Boston, Kluwer Academy Publishers, 1988)

${ }^{104}$ Brooks, J., "Policies and Institutions in Transition Economies: A Political Economy Perspective on the Agri-Food Sector," (pp. 487 - 500) Food Policy, Vol. 20, No. 6 (1995): p. 499

${ }^{105}$ Croley, Steven P., "Theories of Regulation: Incorporating the Administrative Process," (pp. 1 168) Columbia Law Review, Vol. 98, No. 1 (1998): p. 31

${ }^{106}$ Q.Hirst, P. (ed.), The Pluralist Theory of the State: Selected Writings of G.D.H. Cole, J.N. Figgis, and H.J. Laski (London: Routledge, 2005): p. 3
} 
Stigler who, by and large, renders pluralism unfashionable in regulatory decision-making to the works of Peltzman and Becker who take group interests as central to determining regulatory outcomes, in lines with original pluralist thinking. ${ }^{107}$ Private interest-group theories of regulation, as they stand today, have conformed to and mirror such views as those held by public choice theorists who study nonmarket decision-making from the lens of economics, or simply apply economics to political science. ${ }^{108}$ Government regulation is, thus, an equilibrium level of wealth transfer from some groups that are able to organise and engage in collective actions from other groups that do not find it cost-effective to organise and resist having their wealth taken away. ${ }^{109}$ This vision of government regulation is based on several assumptions inherited from a pluralist approach. It requires the society, including the political life, to be divided into numerous overlapping groups where political decisionmaking is to be achieved through endless bargaining and compromise among such groups. In such an approach, groups, despite frequent setbacks, will remain attach to the bargaining process due to achievement of consensus among groups concerning the value of the process itself. Such assumptions are reasons enough to question the universality of such an approach. ${ }^{110}$ A society based on pluralistic values carry consequences that include “distinctive conceptions of public culture, public philosophy, constitutionalism, deliberation, public policy, democracy and free association." ${ }^{111}$ Western democracies have seen in liberalism the solution to overcome the dilemma of bringing a polity, which is divided into heterogeneous groups holding divergent and often incompatible interests, to collective agreements without the application of coerced allegiance. Liberalism and pluralism, thus, go

\footnotetext{
${ }^{107}$ Ibid, p. 56

${ }^{108}$ Mueller, D., Public Choice (Cambridge: Cambridge University Press, 1979): p. 1

${ }^{109}$ Tollison, Robert D., 2001, p. 465

${ }^{110}$ Berg, B., "Public Choice, Pluralism and Scarcity: Implication for Bureaucratic Behavior," (pp. 71 - 82) Administration \& Society, Vol. 16, No. 1 (1984): p 75 \& 81

${ }^{111}$ Galston, William A., Liberal Pluralism: The Implications of Value Pluralism for Political Theory and Practice (Cambridge: Cambridge University Press, 2002): p. 9
} 
hand in hand. ${ }^{112}$ It comes as little surprise when Robert Tollison, a staunch advocate of public choice theory, questions whether interest-group theory [of regulation] a theory of all governments. $^{113}$

\subsection{2: FROM PUBLIC INTEREST TO GOVERNANCE THEORIES}

In general terms, the public-interest theory explains that regulation seeks the protection and benefit of the public at large. By mid 1970s, however, empirical evidence increasingly suggested otherwise. In response, proponents of the theory contended that regulations are created for bona fide public purposes, but are then mismanaged, for one reason or another, with the result that those purposes are not always achieved. ${ }^{114}$ Without going into the debate on the very existence of the public interest theory and the contention that it is a mere concept, confined to a political discourse, applied to support regulation in philosophical and political terms, the theory, nevertheless, has survived and even drawn increasing number of proponents. ${ }^{115}$ Barry Mitnick's definition of regulation as "the public administrative policing of a private activity with respect to a rule prescribed in the public interest" is a reflection to the theory's normative analysis presented as positive theory. ${ }^{116}$ Jorgen Christensen, in a recent volume devoted to the political aspects of the regulation, brings his readers back to the classical public interest theory while discussing competing theories of regulatory

\footnotetext{
${ }^{112}$ Bellamy, R., Liberalism and Pluralism: Towards a Politics of Compromise (London: Routledge, 1999): p. 1

${ }^{113}$ Tollison, Robert D., 2001, p. 471

${ }_{114}$ Posner, Richard A., 1974: p. 36

${ }^{115}$ See Hantke-Domas, 2003: p.188; who argues that the formulation of the concept of the 'public interest theory' is Stigler's and Posner's attempt to create a new benchmark for the Chicago Theory of Regulation.

${ }^{116}$ Mitnick, Barry M., The Political Economy of Regulation (Ney York: Columbia University Press, 1980): p. 7
} 
governance. ${ }^{117}$ For Christensen, the theory should not be seen through its results, or the operationalisation of the public interests, but the focus should be "on the broadness of the interests involved in decision making, the procedure used before conclusions are drawn, and openness as to the decisions made." ${ }^{118}$ Christine Rossell, while defending the notion of the public interest argues that broad policy goals that "are set by government do seem to reflect a conception of the pubic interest that is broader than any individual or group's self-interest." In cases where legislation and regulations have given into powerful individuals and interest groups, for her it "does not mean the public interest is not at least an implicit criterion in the formulating of legislation regulation."119 Since the mid 1980s, governance through regulation thus becomes a central feature, not just in the US, in developed and developing countries alike. Concepts of responsive regulation, smart regulation, regulatory craft and prudent regulator were brought to the fore, all with the stated aim of how regulations can better pursue the public interest agenda. ${ }^{120}$ Jordana and Levi-Faur, while introducing their edited collection on the emergence of the regulatory state, write of regulation "as an art and craft of governance, as an institutional reality, as a field of study, and as a public discourse...more salient and celebrated nowadays than ever before." 121

\footnotetext{
${ }^{117}$ Christensen, Jorgen G., "Competing Theories of Regulatory Governance: Reconsidering Public Interest Theory of Regulation," (pp. 96 - 110) in David Levi-Faur (ed.) Handbook on the Politics of Regulation (Cheltenham: Edward Elgar, 2011)

${ }^{118}$ Ibid, p. 107

${ }^{119}$ Rossell, C., "Using Multiple Criteria to Evaluate Public Policy," (pp. 155 - 184) American Politics Quarterly, Vol. 21, No. 2 (1993): p. 161

${ }^{120}$ On responsive regulation, see: Ayres, I. and Braithwaite, J., Responsive Regulation (Oxford, Oxford University Press, 1992); on smart regulation, see: Gunningham, N. and Sinclair, D. Smart Regulation: Designing Environmental Policy (Oxford: Clarendon Press, 1998); on the concept of regulatory craft, see: Sparrow, Malcolm K., The Regulatory Craft: Controlling Risks Solving Problems and Managing Compliance (Washington D.C.: The Brookings Institute, 2000); and on prudent regulator, see: Beecher, Janice A., "The Prudent Regulator: Politics, Independence, Ethics and the Public Interest," Energy Law Journal, Vol. 29, No. 2 (2008): pp. 577 - 614; also see Baldwin, R., Cave, M. and Lodge, M., 2012: Chapter 12

${ }^{121}$ Jordana and Levi-Faur, 2004: p. 1
} 
In recent times, Steven Croley has, perhaps, provided one of the most qualified defences of regulatory government. ${ }^{122}$ Croley comes to a conclusion that "administrative process helps to promote sound regulation," it "constrains agencies with poor regulatory proposals, as well as empowers agencies seeking to do what is socially beneficial." ${ }^{, 123}$ Croley, through extending the public interest theory, takes agencies' decision-making rules rather than legislative incentives as a central determinant of regulatory outcomes and calls it 'administrative process theory of regulation.' Relying on empirical cases from tobacco industry and of environment regulations, he makes the case that agencies increase social welfare under some circumstances by promoting the diffuse interests of the general public against narrow interest. ${ }^{124}$ For the likes of Robert Kagan, Corley's book is an ambitious, valuable and important contribution "to remind us that the regulatory state quite often does act much more in accordance with public interest theories of regulation than many scholars assume [italics added]." ${ }^{125}$ For Peter Van Doren, though, Croley’s "result is not really good science."126 Needless to say, much of the general criticism levelled in 1970s on the public interest theory is still raised by the protagonists of free-market solutions.

An external challenge to the public interest theory, however, stems from its apparent incapability of crafting desirable regulation in representative democracy. ${ }^{127}$ If elections are the means for the expression of 'public interest' and of holding government responsible to

${ }^{122}$ Also see: Dibadj, Reza R., Rescuing Regulation (New York: State University of New York, 2006)

${ }^{123}$ Croley, Steven P., Regulation and Public Interest: The Possibility of Good Regulatory Governance (Princeton: Princeton University Press, 2008): p. 267; for concise summary of the same see: Croley, Steven P., "Public Interest Regulation," Florida State University Law Review, Vol. 28, No. 7 (2000): pp. $7-107$

${ }_{124}$ Ibid, p. 72

${ }^{125}$ Kagan, Robert A., "Review of the Regulation and Public Interest: The Possibility of Good Regulatory Governance by Steven P. Croley," Law and Politics Book Review, Vol. 18, No. 7 (2008): pp. $640-644$

${ }_{126}$ Doren, Peter Van, "Review the Regulation and Public Interest: The Possibility of Good Regulatory Governance by Steven P. Croley," (pp. 164 - 174) Cato Journal, Vol. 28, No. 1 (2008): p. 172

${ }^{127}$ Aranson, Peter H., 1989-90, p. 247 
such interest, such an interpretation stands little chance with majority rule and minority rights. For Cassinelli, therefore, a few interests that public, as a whole, could possess [even though no society is fully organised] and are discovered, i.e. wellbeing of the community, peace and prosperity, are not sufficient conditions of a democratic ethic. ${ }^{128}$ More fruitful analysis would then be to assess the concept of 'public interest' through its different conceptions vis-à-vis the role of the government in political science. Cochran elaborates, there appears to be four different comprehensions, the 'abolitionist,' the 'normative,' the 'process,' and the 'consensualists,' to classification of theories of the public interest. ${ }^{129}$ Those who belong to 'abolitionist' comprehension simply deny that the concept of the public interest has any meaning or validity. ${ }^{130}$ In normative conception, 'public interest' becomes an ethical standard for evaluating specific public policies. The normative school implies that only government officials have the knowledge and the wisdom to determine what the public interest is, a concept that could only be embodied in its most extreme form in modern totalitarian state. ${ }^{131}$ In words of John Rawls, this would be as if "passengers of a ship are willing to let the captain steer the course," a system where "plural voting may be perfectly just." 132 This notion is closely akin to the older concept of 'common good' and is widely disregarded among contemporary political scientists on the grounds that any such conception will necessary lead to authoritarianism. ${ }^{133}$ Furthermore, in countries where democratic institutions are weak, any conception of 'public interest' based on condemning interest

\footnotetext{
${ }^{128}$ Cassinelli, C. W., "Reflections on the Concept of the Public Interest," (pp. 48 - 61) Ethics, Vol. 69, No. 1 (1958): p. 61

${ }^{129}$ Cochran, Clarke E., "Political Science and the Public Interest," (pp. 327 - 355) Southern Political Science Association, Vol. 36, No. 2 (1974): pp. 329 - 331

${ }^{130}$ Ibid, p. 331 and 347

${ }^{131}$ Weisbrod, Burton A., "Conceptual Perspective on the Public Interest: An Economic Analysis," (pp. 4 - 29) Burton A. Weisbrod, Joel F. Handler and Neil K. Komesar (eds.) Public Interest Law: An Economic and Institutional Analysis (Berkeley: University of California Press, 1978): p. 27

${ }^{132}$ Rawls, J., A Theory of Justice, rev. ed. (Cambridge: Harvard University Press, 2003) p. 205

${ }^{133}$ Smith, Howard R., Democracy and the Public Interest (Athens: University of Georgia Press, 1960): pp. $27-31$
} 
groups will then provide justification for even more authoritarian rule. ${ }^{134}$ For a normative justification of 'public interest' to function to its fullest would be as if Plato's utopian rule exist where "the perfect guardian must be a philosopher." ${ }^{\text {"135 }}$ For consensualists, public interest is only a vague term but a valuable symbol, which is broader than those of specialinterest groups, i.e. consumer interests. Such a symbol requires, on the part of the government, recognition of and consultation with different interests, which might be undermined or overshadowed by the resourceful groups. ${ }^{136}$ If public-interest theories are seen with reference to the political process through which policy is made, such a process could then assume public interest as the aggregation of all interests, or the result of clash of interest or a democratic process of interests reconciliation. ${ }^{137}$ Any aggregation of individual interests would then be based on the utilitarian assumption of the greatest good for the greater number. This would be to the denial of the reality in politics and therefore finds only a few adherents. ${ }^{138}$ On the other hand, if public-interest is seen as the result or equilibrium of the clash of interests or a democratic process of compromise and accommodation, this would bring back the concept to 'politics of interests' and to interest-group theories of regulation. Frank Sorauf, in an earlier work, makes similar categorisations of public interests by seeing the concept through its different adherents who see it as commonly held, or contain superior wisdom or desirability, or are morally imperative, or represent the outcome as a balance of interests, or see it as having no meaning. ${ }^{139}$ The conception which remain worthy and deserving of support in democratic politics, Sorauf argues, is to see public interest as the

\footnotetext{
${ }^{134}$ Toye, J., "Interest Group Politics and the Implementation of Adjustment Policies in Sub-Saharan Africa," in Peter Gibbon, Yusuf Bangura and Arve Ofstad (eds.) Authoritarianism, Democracy and Adjustment: The Politics of Economic Reform in Africa (Uppsala: Nordic Africa Institute, 1992) p. 122

${ }^{135}$ See Plato's 'The Republic'

${ }^{136}$ Cochran, Clarke E., 1974, p. 347

${ }^{137}$ Cochran, Clarke E., 1974, p. 331

${ }^{138}$ Ibid, p. 339

${ }^{139}$ See: Sorauf, Frank J., "The Public Interest Reconsidered," The Journal of Politics, Vol. 19, No. 4 (1957): pp. $616-639$
} 
outcome of compromise, or balance of interests through reconciliation of divergent interests according to established rules and processes. ${ }^{140}$ Flathman arrives at a similar conclusion that "politics of public interest is impossible without the positive exercise of governmental authority and without disinterested service of the public interest by those in authority."141 Other typologies of public interest, i.e. by Wayne Leys and Charner Perry, by Glendon Schubert and by Victoria Held, have all broadly placed the concept as either having utilitarian, pluralistic or dictatorial meanings. ${ }^{142}$ A recent attempt to reflect on and define the concept of 'pubic interest' comes from Stephen King, Bradley Chilton and Gary Roberts. ${ }^{143}$ At several places throughout their essay, they raise the pluralistic conception of 'public interest.' To ask whether there is an identifiable public interest, they argue, would be as if to question the democratic-republican framework. They define public interest as "the formulation of the "golden mean" balance between the interest of competing stakeholders, each representing a specific public with divergent agendas, plans and purposes." ${ }^{\prime 144}$ By subscribing to Michael Harmon's definition of public interest “as the product of the on-going political activity of individuals and interest groups within [a] democratic governance system," they question those who argue that the public interest is nothing more than assertion by public administrators of their individual preferences. ${ }^{145}$ For those who subscribe to and defend 'public interested regulation,' if public interest were not the outcome of competing interests and interplay among individuals, interest groups and government, a tenant of liberal

\footnotetext{
${ }^{140}$ Ibid, p. 639

${ }^{141}$ Flathman, R. E., The Public Interest: An Essay Concerning the Normative Discourse of Politics (New York: Wiley, 1966): p. 66

${ }^{142}$ See: Leys, W. A. R. and Perry, C. M., Philosophy and the Public Interest (Chicago: Committee to Advance Original Work in Philosophy, 1959); Schubert, G., The Public Interest (Glencoe, III: Free Press, 1960); Held, V., The Public Interest and Individual Interest (New York: Basic Books, 1970); for a comprehensive mapping of different typologies of public interest, see: Mitnick, Barry M., "A Typology of Conception of Public Interest," Administration \& Society, Vol. 8, No. 1 (1976): pp. 5 28

${ }^{143}$ King, Stephen M., Chilton, Bradley S. and Roberts, Gary E., "Reflections on Defining the Public Interest," Administration \& Society, Vol. 41, No. 8 (2010): pp. 954 - 978

144 Ibid, p. 955

145 Ibid, p. 961
} 
pluralist democracies, the alternative would then be of benevolent dictatorship or worst. ${ }^{146}$ On the other hand, if public interested regulation were to constitute the utilitarian or normative understandings, representative democracies would be incapable of operating on appropriate margins to craft desirable regulation. ${ }^{147}$

\section{7: A DEVELOPING AGENDA}

The last two decades have seen increasing diversification in studies of government regulation. Regulation, as an academic subject, is not only seen through the lenses of normative or positive economics anymore. In addition to welfare and neoclassical economic approaches to the subject, many other theoretical perspectives and disciplines are now applied for analysing regulation, i.e. anthropology, linguistics, political science, sociology, law and even those which are interdisciplinary in nature. Even within economics, there is now an impetus for an alternative way of thinking of regulation. Andrei Shleifer presents such an approach to which he calls the enforcement theory of regulation, in which optimal institutional design involves a choice among imperfect strategies for social control and recognizing a basic trade-off between [market] disorder and [government] dictatorship. His theory relies on cost and benefits of alternative means of social control of business, from the continuum of free market to private litigation and from regulation to public ownership and thereby pointing to what might be under different circumstances the efficient choice. ${ }^{148}$ Bruce Yandle, on the other hand, with his Bootleggers and Baptists theory of regulation, attempts to combine elements from public interest theories and special interest theories to explain the

\footnotetext{
${ }^{146}$ Messina, A., "Public Relations, the Public Interest and Persuasion: An Ethical Approach," (pp. 29 - 52) Journal of Communication Management, Vol. 11, No. 1 (2007): p. 37

${ }^{147}$ Aranson, Peter, H., 1989-1990: p.270

${ }^{148}$ Shleifer, A., "Understanding Regulation," European Financial Management, Vol. 11, No. 4 (2005): pp. $439-451$
} 
phenomenon of social regulation. Yandle highlights cases where a carefully constructed regulation was beneficial to the industry, and so it pushes for such reforms, while giving the citizenry the impression the only goal is to serve the public interest, therefore also enjoying popular support. In explaining environmental regulations, Yandle makes a case that established firms would benefit from restriction on new entrants, and environmentalists' would profit from measures installed to mitigate pollution, both parties, an unlikely alliance, could gain from properly constructed regulation. However, both theories not only retains elements of political pluralism, its empirical justifications are underdeveloped and largely confined to the regulatory politics of the US. ${ }^{149}$

A third theoretical paradigm based on the institutional perspective is fast burgeoning. Though not as elaborated as the two contending economic theories of regulation, it is now widely considered as central to a proper understanding of the regulatory process. ${ }^{150}$ The theoretical development in the field of regulation, as Baldwin, Cave, and Lodge summarises, has been predominantly a movement towards a growing emphasis on institutional design. ${ }^{151}$ This perspective centres on the institutional structure and arrangements as well as social processes, instead of focusing on individuals' preferences, in shaping regulations. Individuals' preferences, for institutionalists, are influenced and shaped by institutional procedures, principles, expectations and norms that are encountered in cultural and historical frameworks. ${ }^{152}$ Institutionalist literature can be broadly divided into two main strains of prescriptive and descriptive theories. Prescriptive theories focuses on designing inter- or

\footnotetext{
${ }^{149}$ See: Yandle, B., "Bootleggers and Baptists - The Education of a Regulatory Economist," Regulation, Vol. 7, No. 3 1983: pp. 12 - 16; and Yandle, B., "Bootleggers and Baptists in the Theory of Regulation," (pp. 25 - 33) in David Levi-Faur (ed.) Handbook on the Politics of Regulation (Cheltenham: Edward Elgar, 2011)

${ }^{150}$ Ünay, S., "The Rise of the Regulatory State in Europe," (pp. 21 - 31) Turkish Journal of Politics, Vol. 2, No. 1 (2011): p. 22

${ }^{151}$ Baldwin, R., Cave, M. and Lodge, M., 2010: p. 11

${ }^{152}$ Baldwin, R. and Cave, M., 1999: p. 27
} 
intra-institutional relations to avoid particular problems widely associated with regulatory processes, e.g. principal-agent theories or systems theories, while descriptive theories are primarily interested in the politics of regulation looking into analytical elements of regulation design and enforcement. ${ }^{153}$ It is this latter strain of institutionalist literature that has elements of universality and ability to examine questions, as basic as they might seem, of how and why regulations evolve in countries that do no necessarily represent features of a pluralist/liberalist democracies. ${ }^{154}$ The following discussion summarises three such theoretical frameworks that can be adapted to the environments of grey-zone countries.

An important theoretical contribution within the institutionalist literature, namely of regulatory space, comes from the socio-legal perspective and within the context of liberal corporatism. Here, "the range of regulatory issues subject to public decision" defines regulatory space, in which regulatory authority and responsibility are frequently dispersed and "invariably involves interdependence and bargaining between powerful and sophisticated

\footnotetext{
${ }^{153}$ Main contributors to systems theory, also called self-referential accounts of regulation, are Niklas Luhmann, Gunther Teubner and Helmut Willke, for their respective accounts, see: Lange, S. and Schimank, U., "A Political Sociology for Complex Societies: Niklas Luhmann," in Kate Nash and Alan Scott (eds.) The Blackwell Companion to Political Sociology (Malden; Oxford; Victoria: Blackwell Publishing, 2004): pp. 60 - 70; Lange, B., "Understanding Regulatory Law: Empirical Versus Systems-theoretical Approaches?" Oxford Journal of Legal Studies, Vol. 18, Autumn (1998): pp. 450 - 471; Teubner, G. (ed.) Autopoietic Law: An New Approach to Law and Society (Berlin: Walter de Gruyter, 1988); Helmut Willke's contributions to systems theory are published only in German language. On principal-agent theories of regulation, see: McCubbins, Mathew D., Noll, Roger G. and Weingast, Barry R., "Administrative Procedures as Instruments of Political Control," Journal of Law, Economics \& Organization, Vol. 3, No. 2 (1987): pp. 243 - 277; Calvert, Randall L., McCubbins, Mathew D., and Weingast, Barry R., "A Theory of Political Control and Agency Discretion," American Journal of Political Science, Vol. 33, No. 3 (1989): pp. 588 - 611; and Levy, B. and Spiller, Pablo T., "The Institutional Foundation of Regulatory Commitment: A Comparative Analysis of Telecommunication Regulation," Journal of Law, Economics \& Organization, Vol. 10, No. 2 (1994): pp. $201-246$

${ }^{154}$ Baldwin, Cave and Lodge has divided institutionalist literature on regulation into three broad categories of regulation as inter-institutional, intra-institutional and those that emphasize the network and regulatory space understandings of regulation. See: Baldwin, R., Cave, M. and Lodge, M., Understanding Regulation: Theory, Strategy and Practice (Oxford: Oxford University Press: 2012): Chapter 4
} 
actors against a background of extensive state involvement." ${ }^{155}$ In this interplay and competition between various interests, regulatory authority is inherently shared and private interests are driven to, or accept playing legitimate roles in the regulation of themselves, of industry sectors and of wider society. Importantly, the general legal and political culture of any particular society and character of all the organisations involved in the regulatory arena will shape the ways in which relations are manage. ${ }^{156}$ The theory, though, is criticised in its inability to account for the boundaries and explaining the different dimensions of the regulatory space, i.e. relative power of the different actors, the distribution of resource dependence and the nature of the communication flows between actors relevant to the space. ${ }^{157}$ The theory also dose not accord with the hierarchical conception of regulation and offer little normative prescription. But if "drawn out as a framing device, it is possible to see the regulatory space conception as of broader, universal application as a means to interrogate the experience of regulation." 158 It is also suggested that while images of space are a valuable means of understanding regulation's reach and boundaries but a move away from such abstract discussion to detailed analysis of place could help capturing local cultural ordering, which is subject to national and global forces. ${ }^{159}$

Julia Black introduces a theoretical framework of discourse analysis for analysing regulation. ${ }^{160}$ Though rooted in the disciplines of linguistic and anthropology, the framework has great potential to complement institutionalist theories in facilitating analysis of the

\footnotetext{
${ }^{155}$ Hancher, L. and Moran, M., "Organizing Regulatory Space," in Leigh Hancher and Michael Moran (eds.) Capitalism, Culture and Economic Regulation (Oxford: Clarendon Press, 1989): p. 272 $\& 277$

${ }^{156}$ Ibid, 291

${ }^{157}$ Baldwin, R., Cave, M. and Lodge, M., 2012: p. 65

${ }^{158}$ Scott, C., "Analyzing Regulatory Space: Fragmented Resources and Institutional Design," (pp. 329 353) Public Law, Summer (2001): p. 352

${ }^{159}$ Lange, B., "Regulatory Spaces and Interaction: An Introduction," (pp. $411-423$ ) Social \& Legal Studies, Vol. 12, No. 4 (2003): p. 420

${ }^{160}$ Black, J., 2002: pp. $163-196$
} 
historical, organisational, cognitive and communicative aspects of regulation. ${ }^{161}$ Black considers discourse to form the basis of regulation. She explains that discourse "constitutes regulation in that it builds understandings and definition of problems and acceptable and appropriate solutions, it builds operational categories, and produces the identities of and relations between those involved in the process." Examining regulation from the perspective of discourse analysis will, thus, require to look at "whom conversations are between, where they occur within the regulatory process or regime, what they are about, and how they 'work to co-ordinate action and constitute regulation," and "the way that interpretations and conceptualisation are formed, at what understandings are shared and by whom, at which are contested and between whom, and at the strategies used in developing or contesting those understandings, including rhetorical devices. ${ }^{162}$

The theoretical framework of discourse analysis for analysing regulation is an offshoot of a related set of institutionalist literature dubbed as forces of ideas explanation. ${ }^{163}$ Importantly, this school-of-thought did not originally emerge as a theory of regulation in its own right. It served as an important but additional explanatory variable for institutionalists who were exploring reasons of deregulation movement that did not fit well with the account provided by private interest theories or through their own framework of rational choice institutionalism. ${ }^{164}$ However, by late 1990 s, institutionalists increasingly started seeing ideas to have distinct role in politics beyond its institutional effects. ${ }^{165}$

\footnotetext{
${ }^{161}$ Ibid, p 196

${ }^{162}$ Ibid, p. 165 \& $195-196$

${ }^{163}$ Baldwin, R. and Cave, M, 1999: p.26

${ }^{164}$ See: Hood, C., Explaining Economic Policy Reversals (Buckingham: Open University Press, 1994) on exploring how far the policy shift can be understood in terms of the power of ideas; and also: Hall, Peter A., The Political Power of Economic Ideas: Keynesianism Across Nations (Princeton University Press, 1989) on the examination of how and why particular ideas acquire influence over policy and politics.

${ }^{165}$ For discussion on ideas forming their distinct status in institutionalist literature, see: Blyth, Mark M., "Any More Bright Ideas? The Ideational Turn of Comparative Political Economy," Comparative
} 
Today, for some institutionalists, ideas form the basis of the fourth new institutionalism that brings new insights by seeing institutions not only as constrains and external to agents but also as internal to sentient agents, serving both as constraints and constructs about acting in the world. ${ }^{166}$ Essentially, this branch of institutionalist literature maintains that ideas "provide the essential basis of assumed social realities whereby political leaders explain and justify their policies to the public." ${ }^{167}$ Importantly, this school also takes into account that political considerations might distort ideas. Peter Hall's theory of policy paradigm is perhaps the most sophisticated treatment of historical institutionalism for digging deep into understanding the relationship between ideas and policymaking, ideas behind policy change course and process of social learning. ${ }^{168}$ Hall considers policymaking as a process that usually involves three central variables: the overarching goals that guide policy in a particular field, the techniques or policy instruments used to attain those goals, and the precise settings of these instruments. Building on these distinctions, Hall goes further and identifies three distinct kinds of changes in policymaking and names them first-order, second-order and third-order changes. For Hall, first-order changes are whereby instrument settings are changed in the light of experience and new knowledge, while the overall goals and instruments of policy remain the same. However, when the instruments of policy as well as their settings are altered in response to past experience even though the overall goals of policy remain the same, Hall calls this alteration as the second order-change. Finally, any wholesale changes in policy, for Hall, are the

Politics, Vol. 29, No. 2 (1997): pp. 229 - 250; and Schmidt, Vivien A., "Discursive Institutionalism: The Explanatory Power of Ideas and Discourse," Annual Review of Political Science, Vol. 11 (2008): pp. $303-326$

${ }^{166}$ See: Schmidt, Vivien A., Taking Ideas and Discourse Seriously: Explaining Change through Discursive Institutionalism as the Fourth 'New Institutionalism'," European Political Science Review, Vol. 2, No. 1 (2010): pp. $1-25$

${ }^{167}$ Self, P., Government by the Market: The Politics of Public Choice (San Francisco: Westview Press, 1993): p. xii

${ }^{168}$ Hall, Peter A., "Policy Paradigm, Social Learning, and the State: The Case of Economic Policymaking in Britain," Comparative Politics Vol. 25 No. 3 (1993): p. 277 
instances of third-order change. John L. Campbell, while extending the analysis of Peter Hall, goes beyond the effects of interest only and brings the learning from historical and organisational institutionalism and identifies that ideas can be underlying, sometimes takenfor-granted assumptions residing in the background or concepts and theories located in the foreground as articulated by policymaking elites. For Campbell, effect of ideas in policymaking can also be cognitive, descriptions and theoretical analyses that specify causeand-effect relationships, or normative, consisting of values and attitudes. Campbell combines these structural distinctions and identifies four types of ideas as paradigms, public sentiments, programs, and frames. ${ }^{169}$ The key, however, is the connection of ideas with discourse, as the former needs the latter for the explanation of institutional change and continuity. ${ }^{170} \mathrm{Schmidt}$ uses the term discursive institutionalism for this umbrella concept, which includes different types, levels, and representation of ideas as well as its interactive dimension by which ideas are constructed, coordinated and communicated. ${ }^{171}$

Government regulations are, more than often, the result of a complex and dynamic process woven in political and institutional wrangling. No single theoretical framework has been able to fully disentangle the intricacies of regulatory politics. While the analytical construct of regulatory space is useful in mapping out the regulatory arena, understanding of ideas is essential to decipher as to why a particular regulatory policy is opted over others, whereas ideas themselves are rendered meaningless intangibles without the discourse analysis.

\footnotetext{
${ }^{169}$ Campbell, John L., "Institutional Analysis and the Role of Ideas in Political Economy," Theory and Society Vol. 27, No. 3 (1998): p. 377

${ }^{170}$ Schmidt, Vivien A., 2010, p. 11

${ }^{171}$ Schmidt, Vivien A., "Reconciling Ideas and Institutions through Discursive Institutionalism," in Daniel Beland and Robert Henry Cox (eds.) Ideas and Politics in Social Science Research (Oxford and New York: Oxford University Press: 2011): Chapter 2
} 


\section{8: CONCLUDING WORDS}

Anthony Ogus, in his passionate defence of contributions made by economic theories of regulation in the policymaking arena, could not help but to come to the conclusion that "public interest approach...is too naïve; and private interest theory ...is excessively cynical [italic added]." ${ }^{172}$ While both sets of theories have had considerable advancements, they remain center to pluralism theories and represent as such features held to characterise US political system. ${ }^{173}$ There is hardly anything substantial contributed towards building a theory of regulation from the perspective of developing countries or emerging economies, which may not necessarily conform to such political dynamics. ${ }^{174}$ On the other hand, we see regulations, as a mode of governance, is growing more extensive, invasive, and taking new forms across the globe. "If we were to judge neoliberalism by the degree of "deregulation" it attained," write Levi-Faur and Jordana, "it would be a failure." ${ }^{175}$ For them, the institutional advance of regulation within the backdrop of privatisation and domination of neoliberal agenda is nothing less than a paradox. ${ }^{176}$ Institutionalists, in response, have taken two distinct but mutually beneficial academic routes. One which, assumed by new governance theorists, considers regulation as an institutional reality and fixes sight on alternative regulatory strategies to better achieve stated regulatory goals. The other, opted by new institutionalists, analyses regulation and regulatory agents in order to better understand how complex systems

172 "Ogus, A., "W(h)ither the Economic Theory of Regulation? What Economic Theory of Regulation?" (pp. 31 - 44) in Jacint Jordana and David Levi-Faur (eds.) The Politics of Regulation: Institutions and Regulatory Reforms for the Age of Governance (Cheltenham: Edward Elgar, 2004): p. 42

${ }^{173}$ Hägg, P. Göran T., "Theories on the Economics of Regulation: A Survey of the Literature from a European Perspective," (pp. 337 - 370) European Journal of Law and Economics, Vol. 4, No. 4 (1997): p. 354

${ }^{174}$ Bolt, W., "Jean-Jacques Laffont, Regulation and Development," (pp. 317 - 318) De Economist, Vol. 154, No. 2 (2006): pp. $317-318$

${ }^{175}$ Levi-Faur, D. and Jordana, J., "The Making of a New Regulatory Order," (pp. 6 - 9) The Annals of the American Academy of Political and Social Science, Vol. 598, No. 6 (2005): p. 6

${ }^{176}$ Jordana, J. and Levi-Faur, D, 2004: p. 1 
function and produce order, within a particular national context, institutional framework, policy issues, and industry sector, for designing regulatory polices which could complement such social forms. ${ }^{177}$ Both routes are indispensible for countries of grey-zone.

Regulation scholarship needs further advancement through application of theoretical frameworks that are value-free and do not subscribe to, implicitly or explicitly, one or another form of political regime. The analytical construct of discursive institutionalism, perhaps, offers this flexibility to examine regulation while encapsulating specific political, legal and cultural attributes of a particular regulatory setting. There is little likelihood that a single theory could adequately capture the regulatory politics. ${ }^{178}$ The claim and quest for a general theory of regulation, nevertheless, will continue featuring in select quarters.

${ }^{177}$ Carrigan, C. and Coglianese, C., 2011: p. 108

${ }^{178}$ Wright, John S., and Head, B., "Reconsidering Regulation and Governance Theory: A Learning Approach," (pp. 192 - 216) Law \& Policy, Vol. 31, No. 2 (2009): p. 213 



\section{IDEATIONAL INSTITUTIONALISM AND}

\section{POLICYMAKING}

\section{1: INTRODUCTION}

$\mathrm{T}$ heoretical foundation for an institutional explanation of the processes by which public policies are made and evolved was first laid out in the early 1980s. This account the institutional framework of society and rather overtly relying on neoclassical concepts of efficiency. ${ }^{1}$ Trebing while tracing evolution of the two contending economic theories of regulation and their various offshoots points at this very theoretical gap by raising serious doubts about the ability of neoclassical models in producing "analytical concepts and public policy recommendations ... workable in modern national and global economic systems" and concerns over short-sightedness of those belonging to public-interest school to have ignored "public control that produces too much output too inefficiently." 2 As a result, in economics, sociology and in political science, there has been re-emergence, of a sort, of institutional explanation of pubic policy outcomes rather than seeing them as solely behaviourist phenomenon. ${ }^{3}$ This has been loosely dubbed together as new institutionalism.

\footnotetext{
${ }^{1}$ See: Reynolds, L., "Foundation of an Institutional Theory of Regulation," Journal of Economic Issues, Vol. 25, No. 3 (1981): 641 - 656

${ }^{2}$ Trebing, Harry M., "Regulation of Industry: An Institutionalist Approach," Journal of Economic Issues, Vol. 21, No. 4 (1987): 1707 - 1737

${ }^{3}$ Zucker, Lynne G., "Institutional Theory of Organization," Annual Review of Sociology, Vo. 13 (1987): 459
} 
The purpose of this review, then, is to trace this evolutionary process that started quite independently in economics, sociology and political science to the most recent attempts of deciphering the role of ideas in public-policy outcomes within the new institutionalism scholarship. The next section briefly reviews what constitute institutions in new institutionalism and what role do ideas play therein. This sets, in the third section, the foundation for precisely defining the concept of ideas and their affects on public-policy outcomes within the ambit of a latest pillar - ideational institutionalism - in new institutionalism. A comprehensive section follows this that plugs existing theoretical gaps in ideational scholarship by building conceptual clarity on types of ideas and their application on understanding public policy outcomes.

\section{2: INSTITUTIONS AS ACTORS}

In a 1981 essay, Larry Reynolds distinguishes between explicit regulation that are developed consciously and implicit regulations that evolve over time. He explains that implicit regulations are essentially institutions that have evolved through physical, psychological and social mechanisms, which shape explicit regulations that are society's responses to problems, which in turn are influenced by them. For Reynolds, any theory that seeks to explain governmental policymaking must include this dynamic relationship. ${ }^{4}$ Robert Kling, while advancing the work of Larry Reynolds, argues that a successful theory needs to take "account of the political mechanisms by which competing interests are transformed into public policy, and how the changing nature of society... affect what kind of regulation is appropriate and

\footnotetext{
${ }^{4}$ Reynolds, 1981
} 
what kind of regulation indeed will be implemented." Institutional explanation in the formation of social policy, for Kling, not only offered normative ramifications in terms of its practical implications but also had the potential to account for the changes in social conditions over time that affect the direction of policy options in the political process. In the last two decades, advances in the institutional perspective, on its structure and arrangement as well as social processes, has come to take a central place in understanding policymaking and political decision-making. ${ }^{6}$

Study of institutions, however, is not new to sociology, economics and political science and can be traced back to the inception of these disciplines. What is 'new' is regarding institutions as actors in their own right and more than a mere playing field that influence and shape individuals' economic, political and social behaviours. ${ }^{7}$ This understanding contrasts with old institutionalism thinking that theorised leaders from within actively infused organisational structures and processes and, therefore, was interested in formal rules, procedures and political systems and their impact on political practices. ${ }^{8}$ Old institutionalism did not consider external aspects of the context, such as rules, routines, norms and identities, in which organisations existed and passively responding to such forces in their structures and processes. ${ }^{9}$ This is the line of the argument that the new institutionalism has taken in past two decades.

\footnotetext{
${ }^{5}$ Kling, Robert W., "Building an Institutionalist Theory of Regulation," Journal of Economic Issues, Vol. 22, No. 1 (1988): 200

${ }^{6}$ Ünay, S., "The Rise of the Regulatory State in Europe," (pp. 21 - 31) Turkish Journal of Politics, Vol. 2, No. 1 (2011): 22

${ }^{7}$ McConnell, S., "The Old Institutionalism and the New," Polity, Vol. 40, No. 3 (2008): 328

${ }^{8}$ Đurić, I., "The New Institutionalism(s): A Framework for the Study of Public Policy in PostConflict and Post-Communist Countries," Politička misao, Vol. 48, No. 5 (2011): 90

${ }^{9}$ March, James G., and Olsen, Johan P., "Elaborating the "New Institutionalism"," in R. A. W. Rhodes, Sarah A. Binder, and Bert A. Rockman (eds.) The Oxford Handbook of Political Institutions (Oxford: Oxford University Press, 2006): 16
} 


\subsection{1: THE THREE ESTABLISHED NEW INSTITUTIONALISMS}

Scholarship in new institutionalism, as March and Olsen assert, "is far from coherent or consistent," or as Hall and Taylor argue, lacks a "unified body of thought." ${ }^{10}$ However, there is some degree of consensus, at least by the end of the 1990s, in published literature that the new institutionalism falls into three broad categories of rational choice, historical and sociological institutionalisms. The three schools-of-thought have developed quite independently to each other. But they all have in common their discontent with the behavioural perspectives of $60 \mathrm{~s}$ and $70 \mathrm{~s}$, which was a reaction itself against old institutionalism, and their belief in the role of institutions in the determination of social and political outcomes. ${ }^{11}$ At the same time, while all three approaches agree that institutions matter but they disagree over the extent to which they matter. ${ }^{12}$ Rational-choice institutionalists, with Douglass C. North as one of their torchbearers, consider institutions to be only an intervening variable affecting individuals' choices and actions while their strategic calculation remains the central pillar. They concede that institutions set parameters to individuals' actions but they are also the creation of utility-maximising rationalists in order to overcome unpredictability. ${ }^{13}$ Rational-choice institutionalists, therefore, see institutions as a system of rules and incentives created by rational profit-maximisation decisions. Historical institutionalists consider institutions to have a determinant role in individuals' actions as their preferences are formed by institutional context in which they calculate their interests.

Interests, therefore, are the product of interaction among various groups, ideas, and

\footnotetext{
${ }^{10}$ Hall, Peter A. and Taylor, Rosemary C. R., 1996: 936; and March, James G. and Olsen, John P., "The New Institutionalism: Organizational Factors in Political Life," The American Political Science Review, Vol. 78. No. 3 (1984): 734

${ }^{11}$ Hall, Peter A. and Taylor, Rosemary C. R., "Political Science and the Three New Institutionalism," Political Studies, Vol. 44 (1996): 936

${ }^{12}$ Koelble, T., "The New Institutionalism in Political Science and Sociology," Comparative Politics, Vol. 27, No. 2 (1995): 231

${ }^{13}$ Ibid, 232
} 
institutional structures. Policymaking as social learning, the concept advanced by Peter Hall, fits ideally with the argument that structure and past activities affect actors' policy articulation. ${ }^{14}$ Institutions, for historical institutionalists, are thus continuities and pathdependence. For sociologists, individuals' interests are a product of a broader institutional setting where culture, society, and organisational identity are all a contributing factor and where even institutions themselves are dependent on society and culture. For sociologists, institutions are a web of interrelated formal and informal norms that shape parameters of choice and where actors are 'embedded' in a network of personal relationships which serves as an evaluation framework for their choices. ${ }^{15}$ This effectively translates, for all three established new institutionalisms, an ontological standpoint where institutions are seen in stable equilibria, whether with fixed rationalist preferences, self-reinforcing historical paths, or all-defining cultural norms, that serve as constraints on agents' actions. This deterministic view of institutions has led to difficulties for new institutionalists in explaining how do such institutions get changed. ${ }^{16}$ This predicament in new institutionalism explains the turn to ideas, applied as more of a corrective measure and even implying a tacit acknowledgement of their theoretical limitation in explaining institutional change. ${ }^{17}$ Blyth calls this initial interest in ideas among the new institutionalists as "an ad hoc attempt to account for theoretical problems, ${ }^{18}$ However, this instrumental and functional treatment of ideas and an attempt to

\footnotetext{
${ }^{14}$ See Hall, Peter A., "Policy Paradigms, Social Learning and the State: The Case of Economic Policymaking in Britain," Comparative Politics, Vol. 25, No. 3 (1993): 275 - 296

${ }^{15}$ Nee, V. and Ingram, P., "Embeddedness and Beyond: Institutions, Exchange, and Social Structure," in Marcy C. Brinton and Victor Nee (eds.) The New Institutionalism in Sociology (New York: Russell Sage Foundation, 1998): 40

${ }^{16}$ Bell, S., 'Do We Really Need a New 'Constructivist Institutionalism' to Explain Institutional Change?" British Journal of Political Science, Vol. 41, No. 4 (2011): 883

${ }^{17}$ Schmidt, Vivien A., "Discursive Institutionalism: The Explanatory Power of Ideas and Discourse," Annual Review of Political Science, Vol. 11 (2008): 884

${ }^{18}$ Blyth, Mark M., “Any More Bright Ideas? The Ideational Turn of Comparative Political Economy," Comparative Politics, Vol. 29, No. 2 (1997): 229
} 
grapple with questions of institutional change served as an origin of a distinct body of scholarship within new institutionalism referred here as ideational institutionalism. ${ }^{19}$

At around the same time when the three new institutionalisms come to be recognised, there started an increasing impetus on bringing these three established schools-of-thought under comparative lenses. There were calls for greater interchange amongst them in order to better overcome the common difficulties in explaining institutional change that they were trying to wrestle with, more or less, in isolation. Malcolm Rutherford, in a 1995 essay, calls for "reconciliation of the rational and the rule-guided aspects of human behaviour and for a development of a theory of ideology and ideological change. ${ }^{, 20}$ Peter Hall and Rosemary Taylor consider that "time has come for greater interchange among them [new institutionalism] ... a better acquaintance with other schools would lead the partisans of each toward a more sophisticated appreciation for the underlying issues till to be resolved within their own paradigm." ${ }^{21}$ Koelble argues that "the debate over whether culture, structure, or utility-maximization devise individuals to action will undoubtedly continue, but perhaps the contending sides are not as far apart as they might think." ${ }^{22}$ Interestingly, new institutionalists, by and large, have sought explanation in the role of ideas for advancing their particular school-of-thought, be it based on culture, structure or utility-maximisation as an overarching driving factor for individuals' actions. Ideas, on the one hand, became the bridge amongst different schools-of-thought within new institutionalism through which they sough commonalities and, on the other hand resulted in erecting a distinct theoretical body ideational institutionalism - in its own right.

\footnotetext{
${ }^{19}$ See: Schmidt, Vivien A., "Institutionalism and the State," in C. Hay, M. Lister, and D. Marsh (eds.) The State: Theories and Issues (Basingstoke: Palgrave, 2006)

${ }^{20}$ Rutherford, M., "The Old and the New Institutionalism: Can Bridges Be Built?" Journal of Economic Issues, Vol. 29, No. 2 (1995): 450

${ }^{21}$ Hall, Peter A. and Taylor, Rosemary C. R., 1996: 955

${ }^{22}$ Koelble, 1995: 243
} 


\subsection{2: ROLE OF IDEAS IN NEW INSTITUTIONALISM}

Koelble is right in saying that "preferences may be located behind every cultural activity or structure and vice versa."23 The question then becomes how these preferences are shaped, how they are changed over time or completely abandoned and replaced by a new set of preferences and, perhaps more importantly, what role do ideas play in these. For some rational choice institutionalists, while individual's instrumental calculus remains at the centre so as to maximise the attainment from a fixed set of preferences, ideas shaped by a particular institutional environment are the explanation behind why actors move towards one outcome when there are multiple equilibriums, or more than one preferred choices. ${ }^{24}$ Historical institutionalists, on the other hand, have been more open to converge to ideas in explaining public-policy process and change.

Peter Hall, in his seminal work, writes "policymakers customarily work within a framework of ideas and standards that specifies not only the goals of policy and the kind of instruments that can be used to attain them, but also the very nature of the problems they are meant to be addressing." ${ }^{25}$ For sociological institutionalists ideas have always been at the basis of the norms, cognitive frames and meaning systems that guide human action and constitute forms and procedures of organisational life. ${ }^{26}$ The treatment of ideas, therefore, varies in the three schools-of-thought. For rational choice institutionalists, ideas are seen linked to acceptable

\footnotetext{
${ }^{23}$ Ibid

${ }^{24}$ Garrett, G. and Weingast, B., "Ideas, Interest and Institutions: Constructing the European Community's Internal Market," in Judith Goldstein and Robert Keohane (eds.) Ideas and Foreign Policy (Ithaca NY, Cornell University Press, 1993): 173 - 206

${ }^{25}$ Hall, Peter A., 1993: 279

${ }^{26}$ Schmidt, Vivien A., "Taking Ideas and Discourse Seriously: Explaining Change through Discursive Institutionalism as the Forth "New Institutionalism," European Political Science Review, Vol. 2, No. 1 (2010): 11
} 
range of choices and in determination of perceived payoffs. ${ }^{27}$ In the perspective of historical institutionalism, Daniel Béland considers ideas to have a crucial role in the analysis of policy change and see them as "specific policy alternatives as well as the organised principles and causal beliefs in which these proposals are embedded. ${ }^{28}$ Nee and Ingram see ideas in sociological institutionalism as evaluation frameworks of rewards and punishment that are based on social approval or disapproval and characterised by norms, relationships, and networks. $^{29}$

Initially, the study of ideas in the work of new institutionalism was seen less optimistically and more of a theoretical "filler" than as a progressive extension of existing research programmes. ${ }^{30}$ Blyth, critical of the instrumental and functional treatment of ideas in both historical and rational choice institutionalisms, asserts a need to develop a better theoretical understanding of ideas and take them "more than an addendum to institutions." 31 He sees ideas as "both facilitators of radical policy change and prerequisite of it." 32 Subsequent work on the role of ideas in explaining political change in the context of new institutionalism is now dubbed as the "fourth new institutionalism," and in some latest compendiums on new institutionalist scholarship the ideational school is now given a distinct space and recognition. ${ }^{33}$ Before an attempt could be made to define 'institution' within the ambit of ideational institutionalism, it is essential to first delineate what is meant by 'ideas.'

\footnotetext{
${ }^{27}$ Rutherford, M., 1995: 445

${ }^{28}$ Béland, D., "Ideas and Social Policy: An Institutionalist Perspective," Social Policy \& Administration, Vol. 39, No. 1 (2005): 2

${ }^{29}$ Nee, V. and Ingram, P., 1998: 40

${ }^{30}$ Blyth, Mark M., 1997: 229

${ }^{31}$ Ibid, 246

${ }^{32}$ Ibid

${ }^{33}$ Schmidt, Vivien A., 2010: 1; also see for instance: Rhodes, R. A. W., Binder, Sarah A., and Rockman, Bert A., The Oxford Handbook of Political Institutions (Oxford: Oxford University Press, 2006)
} 


\subsection{3: IDEAS AS 'POLICY LOGS'}

In the institutional literature, there seems to be no general convergence among authors on what ideas is and what does it constitute. Even to date, the contemporary literature echoes James Kloppenberg assertion in his 1995 article that the relationship between ideas and institutions need to be clarified. ${ }^{34}$ Understanding of ideas is greatly influences by ones ontological standpoint. For instance, the rational-choice institutionalists ascribe to the understanding where they see ideas secondary to interests and as justification, rationalisation, and instrument of persuasion. ${ }^{35}$ Those who subscribe to historical institutionalism, i.e. likes of Roger Smith and James Kloppenberg, consider ideas to be purposes and projects defining roles of individuals in relation to their institutional environment and constitutive of the self, and also of the concepts of rationality, preferences, and interests. ${ }^{36}$ More recent definitions of ideas, however, are tending to more minimalist in their application. Such as of Lieberman who considers ideas to be a "medium by which people can imagine... and such imaginings spur them to act to try and make changes. ${ }^{, 37}$ Similarly, Hay understands ideas as perceptions comprising desires, preferences and motivations that reflect a normative orientation. ${ }^{38}$ These various conceptions of ideas stem from a particular ontological standpoint and explore the concept from within the limits of their school-of-thought, except, to some degree, for the advancements undertaken by John Campbell and Vivien Schmidt.

\footnotetext{
${ }^{34}$ Kloppenberg, James T., "Institutionalism, Rational Choice, and Historical Analysis," Polity, Vol. 28 No. 1 (1995): 126

${ }^{35}$ See: Fiorina, M., "Rational Choice and the New (?) Institutionalism," Polity, Vol. 28, No. 1 (1995): $107-115$

${ }^{36}$ Smith, Rogers, M., "Ideas, Institutions, and Strategic Choices," Polity, Vol. 28, No. 1 (1995): 136

${ }^{37}$ Lieberman, Robert C., "Ideas, Institutions and Political Order: Explaining Political Change," The American Political Science Review, Vol. 96, No. 4 (2002): 698

${ }^{38}$ Hay, C., "Constructivist Institutionalism," (56- 74) in R. A. W. Rhodes, Sarah A. Binder and Bert A. Rockman (eds.) The Oxford Handbook of Political Institutions (Oxford: Oxford University Press, 2006): 63
} 
Building upon the work of Peter Hall on policy paradigms, Campbell gives, for the first time, an elaborate conception of ideas as providing specific solutions to policy problems, constraining the cognitive and normative range of solutions that policymakers are likely to consider, and constituting symbols and concepts that enable actors to construct frames with which to legitimise their policy proposals. ${ }^{39}$ Campbell here considers ideas to be serving as constraining structures on actors, in line with the argument of the three established new institutionalisms. In a later article, Campbell gives a more wholesome definition of ideas calling them "theories, conceptual models, norms, world views frames, principled beliefs and the like, rather than self-interests, affect policy making. ${ }^{40}$ In this case, Campbell clearly distinguishes ideas from interests and treats them as two distinctive concepts. Vivien Schmidt is the most revolutionary of ideational institutionalists and is among the forerunners of giving this particular offshoot in institutionalist debate a distinct identity. She writes of ideas as of "simultaneously constraining structures and enabling constructs of meaning which are internal to 'sentient' (thinking and speaking) agents whose "background ideational abilities" explain how they create and maintain institutions at the same time that their "foreground discursive abilities" enable them to communicate critically about those institutions, to change (or maintain) them. ${ }^{41}$ Schmidt, while tallying different definitions and conceptions of ideas, also provides a functional understanding and distinguishes ideas as per its level of generality, i.e. specific to a particular policy, encompassing a wider program or constituting an underlying philosophy, and in terms of its appeal, i.e. cognitive for constituting interests and normative to appeal to values and norms. ${ }^{42}$ Rather than bridging gaps and aiming to build a more holistic understanding of the term in order to connect different schools-of-thought in

\footnotetext{
${ }^{39}$ Campbell, John L., "Institutional Analysis and the Role of Ideas in Political Economy," Theory and Society, Vol. 27, No. 3 (1998): 398

${ }^{40}$ Campbell, John L., "Ideas, Politics, and Public Policy," Annual Review of Sociology, Vol. 28 (2002): 21

${ }^{41}$ Schmidt, Vivien A., 2010: 3

${ }^{42}$ Schmidt, Vivien A., 2008: 321
} 
new institutionalism, Schmidt, as she herself states, believes in the distinctiveness of ideas. ${ }^{43}$ The understanding of ideas constructed by Schmidt in contrast to that of Campbell is revolutionary on two accounts. First, Schmidt does not consider ideas and interests to be two distinct concepts but rather the former constituting the later. Second, ideas for Schmidt are both constraining structures as well as enabling constructs, and thereby she implies a much more dynamic understanding of the term than of Campbell. However, Schmidt's understanding of ideas as cognitive [what is and what to do] and normative [what is good or bad in light of what one ought to do] falls short of fully appreciating the subjective dimension of constituting interests [what is ones gain or loss in view of what is], though she herself infers "interests are subjective and norm-driven." 44 The notion of ideas as frames is comparatively a more wholesome conception then, which merits potential with its ability to link cognition to norms and understanding to action. ${ }^{45}$

In a 1989 essay, Bruno Jobert talks of ideas as in "frame of reference" and links it to the cognitive, instrumental and normative dimensions of policymaking. ${ }^{46}$ He explains cognitive dimension as a "common intellectual interpretative framework" through which policymakers evaluate probable effects of their actions. Instrumental dimension provides "set of recipes" or the policy instruments available to carryout intended action, and he describes the normative dimension comprising political culture and values. ${ }^{47}$ The concept of ideas as référentiel or referential has primarily originated from the Research Centre on Territorial Planning (CERAT) based in Grenoble in France and the literature has been mostly in French, except for a handful of papers written in English by individuals who are associated with the research

\footnotetext{
${ }^{43}$ Ibid, 304

${ }^{44}$ Ibid, 306 and 318

${ }^{45}$ Gooby-Taylor, P., "Ideas and Policy Change," (1 - 11) in Peter Taylor-Gooby (ed.) Ideas and Welfare Sate Reform in Western Europe (New York, Palgrave Macmillan, 2005): 4

${ }^{46}$ Jobert, B., “The Normative Framework of Public Policy," Political Studies, Vol. 37 (1989): 377

${ }^{47}$ Ibid, $377-78$
} 
programme. This explains the relative paucity of its use in institutional literature for the analysis of public-policy outcomes and where it is used is mostly as a passing reference to the study of ideas. Initially, the work on ideas as referential was presented as a cognitive approach, and therefore also referred to as cognitive frameworks, implying a constructed mental framework of action for actors. In later writings, the normative dimension is also added. ${ }^{48}$ Muller, one of the researchers from CERAT, writes that referential is "a representation, an image of reality that policy actors want to modify," and that "this image orients the conception of problems, solutions and proposal elaborated by policy actors. ${ }^{, 49} \mathrm{He}$ then expands this understanding and includes values, norms, algorithms and vision of the worlds as constituting referential..$^{50}$ Together with Surel, Muller further elaborates this understanding of referential as "arrangements of intellectual, normative or cognitive frames that simultaneously determine the tools through which societies can work on themselves and the arena of meaning within which social groups will interact.. ${ }^{51}$ Jobert and Muller also use the term of 'mediator,' somewhat similar to the concept of 'epistemic community' of Hass or of 'advocacy coalition framework' of Paul Sabatier and Hank Jenkins-Smith but more broadbased in its membership, that produces the referential and comprises "the actor, as a group or an individual...considered as the truth at a specific moment. ${ }^{, 52}$ This implies cognitive frames as constructions from outside that are then used as intellectual and normative references by the policymaker to determine tools for problem solving. For this, they need access to the

\footnotetext{
${ }^{48}$ Gouin, Rodolphe and Harguindéguy, Jean-Baptiste, "The Use of Cognition in Policy Analysis: A First Appraisal," Journal of Public Administration and Governance, Vol. 2, No. 1 (2012): 6

${ }^{49}$ Muller, P., Les Politiques Publiques (Paris: Presses Universitaires de France, 1990)

${ }^{50}$ Muller, P., "Les Politiques publiques comme Construction d'un Rapport au Monde," in A. Faure, G. Pollet and P. Warin (eds.) La Construction du Sens dans les Politiques publiques: Débat Autour de la Notion de Référentiel (Paris: L'Harmattan, 1995): 158

${ }^{51}$ Muller, P. and Surel, Y. L'analyse des Politiques Publiques (Paris: Editions Montchrestien, 1998): 11

52 Jobert, B. and Muller, P., L'Etat en Action (Paris: PUF, 1987); Haas describes 'epistemic community' compose of experts that produce shared understanding on how problems are perceived and their solutions are considered in: Hass, P. "Do Regimes Matter? Epistemic Communities and Mediterranean Pollution Control," International Organization, Vol. 43, No. 3 (1989): 377 - 403
} 
political agenda and be diffused in policy circles to become a reference for actions. This comprehension carries two limitations. First, it becomes overtly prescriptive focusing less on the creations and change of institutions and more on the instrumental dimension of ideas. Second, it shuts itself from the possibility of policy behaviours of an individual or a group of individuals acting in pursuit of their own interests using ideas to build incentive structures and to reduce uncertainties.

Nevertheless, understanding ideas as a "frame of reference" takes distinction over other conceptions of the term in the three established new institutionalisms as, on the one hand, it not only constrains actors' decisions making but also becomes "a tool to shape and modify reality." ${ }^{, 53}$ It also differs in a sense that it implies a reciprocal relationship between ideas and public policy influencing the construction of each other than the univocal relationship as described in rational-choice, historical or sociological institutionalisms. ${ }^{54}$ Seeing ideas as a "frame of reference" to a public-policy outcome is particularly useful considering policymakers usually operate at various levels, cognitive, normative and subjective interpretations of interests, for evaluation of their decisions. It is in this context the term 'ideas' is conceived as the basis for policy decisions, central to how policymakers conceive and evaluate their options and how and what they decide. Its construction is the result of exogenous factors, i.e. culture, norms, or scripts, or endogenous to organisation, i.e. rule-like qualities, structure action and regularised practices, or internal to actors as in subjective calculus of interests, intellectual determination of optimal course of action or assumptions of public sentiments, or a mix of thereof. Ideas are, thus, seen as a 'policy log' containing references to the basis for a policy action. Such a 'policy log' will have a dominant set of

\footnotetext{
${ }^{53}$ Simoulin, V., "Emission, médiation, réception... Les opérations constitutives d'une réforme par imprégnation," Revue Française de Science Politique, Vol. 50, No. 2 (2000): 334 ${ }^{54}$ Musselin, C., "The role of Ideas in the Emergence of Convergent Higher Education Policies in Europe: The Case of France," Working Paper Series No. 73, Center for European Studies (2000): 22
} 
entries as the basis for a policy action but might also be filled with a complex algorithm of interplay of exogenous, endogenous and internal factors derived from the 'meaning context. ${ }^{55}$ The basis for every public policy is thus imprinted on a blank page of a 'policy log' that contributes in the creation, sustenance or change of institutions and which may generally be filled through references to past entries. In contrast to the static nature of rational-choice, historical and sociological institutionalism, 'policy logs' are inherently dynamic and connects theoretical paradigms from positivism to constructivism. Furthermore, 'policy logs' are specific to each policy actors that work as different threads to build up the genome of the institution form which they have originated and where the rest. Having understood ideas as 'policy logs,' we now turn to outlining ideational institutionalism.

\subsection{4: IDEATIONAL INSTITUTIONALISM}

The importance of ideational process in policymaking and to the understanding of institutional change and continuity, in view of the recent theoretical and empirical advancements, has formed a distinct identity of its own in the field of political economy. Different adjectives have been used to distinct this particular school-of-thought from the three established new institutionalism, i.e. ideational, discursive, and constructivist institutionalism. ${ }^{56}$ Here, the term ideational is preferred over other adjectives as the focus is

\footnotetext{
${ }^{55}$ Schmidt describes 'meaning context' as a treatment of ideas as empirical subjects to be studied in their own right beyond as apposed to putting them into cultural context in sociological institutionalism, historical rules and regularities in historical institutionalism or universally identifiable interests in rational-choice institutionalism.

${ }^{56}$ See: On discursive institutionalism, Schmidt, Vivien A., "Discursive Institutionalism: The Explanatory Power of Ideas and Discourse," Annual Review of Political Science, Vol. 11 (2008): 303 - 26; on constructivist institutionalism, Hay, C., "Constructivist Institutionalism," (56 - 74) in R. A. W. Rhodes, Sarah A. Binder and Bert A. Rockman (eds.) The Oxford Handbook of Political Institutions (Oxford: Oxford University Press, 2006); and on ideational institutionalism, Hay, C., "The 'Crisis' of Keynesianism and the Rise of Neoliberalism in Britain: An Ideational Institutionalist Approach" in John L. Campbell and Ove Pedersen (eds.) The Rise of Neoliberalism and Institutional Analysis (Princeton: Princeton University Press, 2001)
} 
on the role of ideas rather than the means, i.e. interpretive or interactive processes, through which institutions are created, sustained and changed and policies are influenced, contested and shaped. However, regardless of the use of any adjective, as Schmidt explains, what is common is the interest in the role of ideas and ontologically considering policymaking a more dynamic process than a result of an equilibrium-focused outcome in a static institutional setting. Its origination is in the desire to capture, describe and interrogate institutional disequilibrium, as Hay conjectures other new institutionalist approaches "rely albeit for rather different reasons on the assumption of equilibrium, were theoretical non-starters." ${ }^{, 57}$ The ideational turn in new institutionalist literature is by far the most recent and still an emerging scholarship. Earlier attempts to turn to ideas were more of a corrective nature and with an objective to fill-in theoretical gaps within the three established new institutionalisms. Lately, there have been assertions of giving ideational dimension a distinct identity and recognition of its own in new institutionalism. ${ }^{58}$ The reason is the distinctiveness of ideational institutionalism in its ontological, analytical and methodological approaches.

In ideational institutionalism literature, there have been only a handful of attempts to define institutions and its relationship with ideas and even that gives alternative accounts of what institutions are and what do they constitute. Schmidt, who is among the pioneers of brining ideational dimension in new institutionalism, defines institution as "meaning structures and constructs" that are "internal to agents whose "background ideational abilities" and "foreground discursive abilities" make for a dynamic, agent-centred approach to institutional change." 59 In ideational context, and as Schmidt elaborates, "institutions are therefore internal to the actors, serving both as structures that constrain actors and as constructs created

\footnotetext{
${ }^{57}$ Hay, C., 2006: 60

${ }^{58}$ Schmidt, Vivien A., 2008: 304; also see Blyth, Mark M., 1997

${ }^{59}$ Ibid, 305
} 
and changed by those actors. ${ }^{60}$ Schmidt further explains that in ideational institutionalism, “Agents' background ideational abilities [what goes on in individuals' minds as they come up with new ideas] enable them to act in any given meaning context to create and maintain institutions while their foreground discursive abilities [to reason, debate] enable them to communicate critically about those institutions and so to change or maintain them."61 This is why Schmidt prefers to call this as discursive institutionalism, instead of ideational or constructivist, where ideas serve as substantive content of discourse and discourse is needed for an interactive process to convey ideas. Schmidt distances herself from rational-choice institutionalists by arguing that interests in discursive institutionalism are 'subjective' rather than 'objective' or 'material' as is the case in the latter and finds commonalities primarily in sociological institutionalism. ${ }^{62}$ Schmidt challenges the underlying assertion in the three established new institutionalisms where institutions are seen as given, whether as in continuing structure or as the context within which agents act and therefore they remain external serving as constraints. She argues that in ideational context, on the contrary, institutions are not only given but are also contingent upon agents and therefore they are "internal to the actors." ${ }^{63}$ On the other hand, Schmidt does not rule out the possibility of "agents to think, speak, and act outside their institutions even as they are inside them, to deliberate about institutional rules even as they use them, and to persuade one another to change those institutions or to maintain them. ${ }^{, 64}$ Schmidt continues to make the case for the necessity of 'discourse' for an ideational understanding to hold that "an interactive process is what enables agent to change institutions, because the deliberative nature of discourse allows them to conceive of and talk about institutions as objects at a distance, and to dissociate

\footnotetext{
${ }^{60}$ Ibid, 314

${ }^{61}$ Ibid, 322

${ }^{62}$ Ibid, 317

${ }^{63}$ Schmidt, Vivien A., 2008: 314

${ }^{64}$ Ibid
} 
themselves from them even as they continue to use them." Colin Hay, who prefers to call himself a constructivist institutionalist, argues somewhat on similar lines as Schmidt but does not talk of institutions as internal and rather considers them to be "codified systems of ideas and the practices they sustain." ${ }^{, 65}$ Hay, in contrast to historical institutionalism, talks of 'ideational path dependence' whereby he argues “it is not just institutions, but the very ideas on which they are predicated and which inform their design and development, that exert constraints on political autonomy." He continues that actors "perception about what is feasible, legitimate, possible and desirable are shaped both by the institutional environment in which they find themselves and by existing policy paradigms and world-views. It is through such cognitive filters that strategic conduct is conceptualised and ultimately assessed."66 Mark Blyth, also among the influential ideational institutionalists, is mainly interested in the role of ideas in determining policy choice and those too especially in crisis situation with a goal to decipher relationship between institutions, interest and ideas. ${ }^{67}$ For Blyth, ideas serve as blueprints for the design of new institutions and "to reduce uncertainty, propose a particular solution to a moment of crisis and empower agents to resolve that crisis by constructing new institutions in line with these new ideas [emphasis added]." ${ }^{68}$ While Blyth does not subscribe to any particular adjective to distinguish himself, he is quite critical of instrumental and functional treatment of ideas in the three established new institutionalisms and contends "ideas have to be taken as more than an addendum to institutions," he writes and continues, "they must be conceptualised apart from pre-existing categories and epistemological commitments and treated as an object of investigation in their own right."69

\footnotetext{
${ }^{65}$ Hay, C., 2006: 58

${ }^{66}$ Ibid, 65

${ }^{67}$ See: Blyth, Mark M., Great Transformation: Economic Ideas and Institutional Change in the Twentieth Century (Cambridge, UK: Cambridge University Press, 2002)

${ }^{68}$ Ibid, 10-11

${ }^{69}$ Blyth, Mark M., 1997: 246
} 
While still maturing, ideational scholarship is not without criticism, which is inflicted from theorists inside as well as from outside institutionalist scholarship. ${ }^{70}$ The most formidable of this comes from a fellow neo-institutionalist Stephen Bell, who aptly sums up differences in ideational discourse as varying "from postmodern accounts, where ideas, inter-subjective meanings and discourse are primitive and wholly define or constitute social and institutional life, to more ontological realist accounts, which admit that institutions and wider structures can have real effects." ${ }^{, 71}$ Bell argues that Schmidt in her thesis "perceives only one dimension of the two-way dialectical interaction between agents and institutions," the latter he argues is "ontologically prior to the individuals who populate them at any given time." 72 Bell is right in pointing out the weakness in Schmidt's analysis but therein also highlights the key difference between ideational institutionalism and the three established new institutionalisms. In ideational institutionalism, it is neither institution nor ideas that are conceived ontologically prior to one another rather the design and development of institutions is based on ideas which once developed effect their subsequent development as well as actors' perceptions about what is feasible, legitimate, possible and desirable. ${ }^{73}$ In his defence of historical institutionalism, Bell conceives agents, institutions, structures and ideas to be mutually constitutive in a dialectical manner. In ideational institutionalism, however, ideas are the blueprint of a dialectical relationship among agents in a manner of becoming their cognitive filters to interpret environmental signals, institutions being built upon ideational foundation and structures serving as constraints shaping options and strategies once formed but yet dependent on agent for its sustenance and continuity. Bell's third criticism is on the mechanism and origin of ideas in ideational scholarship as he writes, "ideas do not operate in

\footnotetext{
${ }^{70}$ See: Panizza, F. and Miorelli, R., "Taking Discourse Seriously: Discursive Institutionalism and Post-structuralist Discourse Theory," Political Studies, (2012) doi: 10.1111/j.1467-

9248.2012.00967.x; and Bell, S., "Do We Really Need a New 'Constructivist Institutionalism' to Explain Institutional Change?” British Journal of Political Science, Vol. 41, No. 4 (2011): 883 - 906

${ }^{71}$ Bell, S., 2011: 889

${ }^{72}$ Ibid, 891

${ }^{73}$ Hay, C., 2006: 65
} 
a vacuum but are instead 'embedded in a historical context and need institutional support to be effective." 74 This criticism holds ground in a sense that there is only scantly written material either on the origin or the mechanism of ideas through which they operate, a subject taken in more detail in the next chapter. At this stage of the analysis it is sufficient to state that, though limited in number, substantial work does exist in discourse analysis on which origin and mechanism of ideas can be operationalized.

How are we then to define institutions in ideational institutionalism? The answer may lies in looking for commonalities among ideational theorists. With slightly differing accounts, the main commonalities among ideational institutionalists and their divergences from the three established new institutionalisms are primarily three. Firstly, ideational institutionalists imply a dynamic understanding of the relationship between institutions and agents in contrast to what Schmidt calls "sticky" definition of the same by the three established new institutionalisms with its deterministic influence either through fixed rationalist preferences, self-reinforcing historical paths or all defining cultural norms. ${ }^{75}$ Secondly, and related to the first difference, the three established new institutionalisms treat institutions as given within which agents actions are dictated and therefore they serve mainly a constraining role conforming to a rule-following logic. One of the main reasons why the three established schools in new institutionalism have been better able to explain continuity but run into trouble in explaining policy change and resort to explanation of exogenous shocks, dramatic events or crises situation. ${ }^{76}$ In ideational understanding, and as Schmidt argues, institutions are not only constraining structures but also enabling constructs. ${ }^{77}$ Furthermore and as Hay

\footnotetext{
${ }^{74}$ Bell, S., 2011: 891

${ }^{75}$ Schmidt, Vivien A., 2008: 304

${ }^{76}$ Schmidt, Vivien A., 2010: 2; also see for historical explanation to institutional change: Krasner, S., "Approaches to the State: Alternative Conceptions and Historical Dynamics," Comparative Politics, Vol. 16 (1984): $223-246$

${ }^{77}$ Schmidt, Vivien A., 2008: 305
} 
elaborates, "institutions are built on ideational foundations which exert an independent path dependent effect on their subsequent development." ${ }^{78}$ Finally, actors in ideational understanding are both strategic and socialised making their actions more flexible as their desires, preferences and motivations are not a contextually given fact rather ideational towards the context in which they are to be realised. ${ }^{79}$ In the words of Blyth then it is 'ideas' that makes interests actionable. ${ }^{80}$ Or as Schmidt argues that interests neither objective nor material as they are subjective ideas. Within this context, institutions are thus defined as an interrelated collection of ideational constructs that is itself affected by its institutional environment for its subsequent design and development. Such constructs are internal to sentient agents that enable them to evolve, adopt and innovate but together they constitute external structures serving primarily as constraints. For example, they may be thought to embed history and political thought and to reflect, therefore, a set of traditions and practices, whether written or unwritten. Institutions thus can be interpreted as reflecting habits and norms, more likely to be evolved than to be created. But institutions also may be seen as architecture and as rules that determine opportunities and incentives for behaviour, inclusion and exclusion of potential players, and structuring the relative ease or difficulty of inducing change, and the mechanisms through which change may be facilitated or denied. In contrast with rational-choice institutionalism where rational actors purse preferences following a 'logic of calculation,' or in historical institutionalism in which regularised patterns and routines are the result of agents acting according to 'logic of path-dependence,' or in sociological institutionalism where actions are response to socially constituted and culturally framed actions as outcomes of 'logic of appropriateness,' agents in ideational institutionalism are salient and socialised who devise, deliberate and legitimise their actions according to the

\footnotetext{
${ }^{78}$ Hay, C., 2006: 65

${ }^{79}$ Ibid, 64

${ }^{80}$ Blyth, Mark M., 2002: 39
} 
'logic of discourse. ${ }^{, 81}$ With this understanding, the next section fills existing theoretical gaps in ideational institutionalism on typology of ideas.

\section{3: TYPOLOGY OF IDEAS}

One of the key problems that beset the ideational analysis is the conceptual confusion about different types of ideas. ${ }^{82}$ While even the staunchest of advocates of ideational institutionalism concede that it is still very much a work in progress and needs better theoretical understanding, there is considerable literature amassed over the period of last 20 years on the taxonomy of ideas. ${ }^{83}$ The role of ideas in public-policy outcomes can only be appreciated once there is precise differentiation between different types of ideas. As Campbell writes "one cannot go about seeing either how ideas affect outcome, or how they originate without specifying what types of ideas we are talking about in the first place." 84

Ideationalists generally trace their origins to historical institutionalism and, most noticeably, in the work of Peter Hall. In his 1993 seminal work on 'policy paradigms,' Hall turns to ideas to understand the policy process beyond a response to societal pressures as identified by pluralist analysis or defined purely by the pursuit of the 'national interest'. He sets the

\footnotetext{
${ }^{81}$ Schmidt, Vivien A., "Comparative Institutional Analysis," in Todd Landman and Neil Robinson (eds.) The Sage Handbook of Comparative Politics (London: Sage Publications, 2009): 126; 'logic of discourse' is preferred over 'logic of communication,' as implied by Schmidt, since the latter is understood only having interactive dimension whereas discourse is much broader than this also containing interpretative and constructive abilities.

${ }^{82}$ Campbell, John L., "What do we Know - Or Not - About Ideas or Politics?" (157-76) in Peter Nedergaard and John L. Campbell (eds.) Politics and Institutions (Copenhagen: DJOEF, 2008): 159 ${ }^{83}$ Blyth, Mark M., 1997: 245; Hay, C., 2006: 72; In addition to those by Peter Hall, John Campbell and Vivien Schmidt, typologies of ideas are also developed by: Tannenwald, N., "Ideas and Explanation: Advancing the Theoretical Agenda," Journal of Cold War, Vol. 7, No. 2 (2005): 13-42; Lynggaard K., "Ideas in EU Decision Making: Towards a Typology of Ideas and Ideational Change," (209-236) in Steen Scheuer and John Damm Scheuer (eds.) The Anatomy of Change - A Neoinstitutionalist Perspective (Copenhagen: Copenhagen Business School Press, 2008)

${ }^{84}$ Campbell, John L., 2008: 166
} 
foundation of his theoretical framework on the concept of 'social learning' that emphasises on the role of ideas as central to policymaking. He recognises that who use this concept "have yet to develop an overarching image of the way in which ideas fits into policy process. ${ }^{, 85}$ For Hall, policymaking essentially revolves around three central variables of "the overarching goals that guide policy in a particular field, the techniques or policy instruments used to attain those goals, and the precise settings of these instruments." ${ }^{.86}$ He then links ideas to policymaking as frameworks in which policymakers work and which specifies for them "the goals of policy and the kind of instruments that can be used to attain them, but also the very nature of the problems they are meant to be addressing. ${ }^{, 87}$ Hall uses Thomas Kuhn's analogy of 'scientific paradigms' to make the case of three orders of change in policymaking. A first-order change is where only the levels of basic instruments are altered and the secondorder change is when the techniques being used to attain the overarching goals are changed. Hall relates the first- and second-order changes to Kuhn's 'normal science' in which the overall policy paradigm remains unchallenged. In contrast, a third-order change where all three components of policy are changed, the instrument setting, the instruments themselves and the hierarchy of goals behind policy, to which Hall relates to 'paradigm shift.'

The work on 'policy paradigm' introduced by Peter Hall is crucial for the application of ideational institutionalism to the field of policymaking for several reasons. Most importantly it provides, for the first time, a dynamic and elaborated framework of policymaking where ideas takes a central place in new institutionalism than a mere filler to its theoretical gaps. It also attempts to bridge the gap between the two contending models based either on public or private interests and sees policymaking as a process where power in the former and ideas in

\footnotetext{
${ }^{85}$ Hall, Peter A., 1993: 276

${ }^{86}$ Ibid, 278

${ }^{87}$ Ibid, 279
} 
the latter could go together. It sees ideas as both 'constraining structures' where they condition policymaking to a particular routine of what can and should be done but they also become 'enabling constructs' that "bolster or induce changes in institutional routine." ${ }^{\text {"88 }}$ Hall also highlights political discourse as a means through which ideas flow from society to the state lending "legitimacy to some social interests more than others, delineates the accepted boundaries of state action, associates contemporary political developments with particular interpretations of national history, and defines the context in which many issues will be understood." ${ }^{89}$ Hall's understanding of ideas as frameworks that become the medium through which policymakers communicate is similar to the proposed concept of 'policy log' that becomes the basis through policymakers defend existing institutions or make a case for their replacement with a new one. However, as Hall himself admits, his analysis fall short of a more "refined appreciation of the role of ideas in politics." ${ }^{.90}$ His analyses are incompatible with endogenous institutionalist account of the mechanism and determinants of institutional change. ${ }^{91}$ While Hall does not elucidate on different types of ideas and provides only its functional understanding at different levels of policymaking, his analysis have been widely used in subsequent ideational literature.

John Campbell has made important advancements in studying the effects of ideas on policymaking outcomes. In his first major publication on the subject, Campbell sharpens the concept of ideas and their effect on policymaking building upon the work of Peter Hall. He compares existing insights on ideas in historical institutionalism and organisational institutionalism to create a typology of ideas based on structural dimensions of normative and cognitive levels, which he considers operate both explicitly in the foreground and as

\footnotetext{
${ }^{88}$ Ibid, 290

${ }^{89}$ Ibid, 289

${ }^{90}$ Ibid, 292

${ }^{91}$ Hay, C., 2006: 62
} 
underlying assumptions in the background of policy debates. Campbell's typology consists of four distinct types of ideas, namely programs operating at the foreground and paradigms, in contrast, functioning in the background at the cognitive level and frames in the foreground as apposed to public sentiments in the background at the normative level of public-policy making. Campbell defines programmatic ideas, which locate at the foreground of policy debates, as concrete solutions "that specify cause-and-effect relationships and prescribe course of policy action." 92 Ideas as paradigms, which also operate at the cognitive level, reside in the background of policy debate and are the "underlying theoretical and ontological assumptions about how the world works. ${ }^{, 93}$ At the normative level of the policy debate, ideas as public sentiment "consists of broad-based attitudes and normative assumptions about what is desirable or not," that work at the background..$^{94}$ Ideas as frames are "symbols and concepts" also normative in their orientation but residing at the foreground of the policy debate through which policymakers "appropriate and manipulate public sentiments for their own purpose." 95 Through empirical cases from the United States, Campbell then makes a case that different types of ideas, as identified by their structural features, have different effects on policy making.

Campbell's work provides a passionate analysis of what do we mean by ideas and how they affect policymaking outcomes. It also advances the argument that ideas, as apposed to historical institutionalism, are not just constraints on actors limiting their possibilities for action but are also enabling factors that generate solutions for problems. ${ }^{96}$ Campbell also advances historical institutionalism in its approach of treating ideas through normative lenses

\footnotetext{
${ }^{92}$ Campbell, John L., 1998: 386

${ }^{93}$ Ibid, 389

${ }^{94}$ Ibid, 392

${ }^{95}$ Ibid, 394

${ }^{96}$ Ibid, 382
} 
only and brings insights from the organisational institutionalism to add a cognitive dimension offering a more dynamic theory of action. ${ }^{97}$ Importantly and in contrast to Peter Hall and more generally to new institutionalism's inability to appreciate agency [who said what to whom] over structures [what is said, or where and how], Campbell has put considerable credence to actors, as is the case in ideational institutionalism, and their ability to "self-consciously devise solutions to their problems by deliberately manipulating explicit, culturally given concepts that reside in the cognitive foreground. ${ }^{98}$ However, Campbell sees ideas and interests distinctively and is interested in the interaction of the two rather than seeing one shaping the other. ${ }^{99}$ In a subsequent article in 2002, Campbell endorses another type of idea to its existing typology of ideas and calls it world culture. ${ }^{100}$ He explains it as either cognitive paradigm or normative framework or a combination thereof with its ability to be diffused around the world and homogenising national political institutions and policymaking apparatuses. ${ }^{101}$ Campbell's typology of ideas and theoretical framework, which brings back agent and agency into institutional scholarship, are important contributions in delineating mechanism through which ideas affect policymaking outcomes as well as in terms of bringing overall conceptual clarity. In his more recent article on ideas and its influence on policymaking, Campbell agrees, "Interests are just another type of idea," which is "rooted in people's perceptions of their material situations." 102 This is an important concession and one that constructivists have been emphasising in their ideational analysis. Hay writes, "[Actors] desires, preferences, and motivations are not a contextually given fact a reflection of material or even social circumstances - but are irredeemably ideational,

\footnotetext{
${ }^{97}$ Ibid, 383

${ }^{98}$ Ibid

${ }^{99}$ See: Campbell, John L. Institutional Change and Globalization (Princeton: Princeton University Press, 2004)

${ }^{100}$ Campbell, John L., "Ideas, Politics, and Public Policy," Annual Review of Sociology, Vol. 28 (2002): $21-38$

${ }^{101}$ Ibid, 25

${ }^{102}$ Campbell, John L., 2008
} 
reflecting a normative orientation towards the context in which they will have to be realised." 103 Interests therefore, whether public or private, are social constructions. This is the line of argument that Kathryn Sikkink takes in her book Ideas and Institutions. She writes, "Ideas are lens, without which no understanding of interests is possible. Ideas transform perceptions of interest, shaping actors' self understanding of their own interest." Lieberman defines ideas as constituting "much of the substantive raw material upon which institutional theory feeds - the goals and desires that people bring to the political world and, hence, the ways they define and express their interests; the meanings, interpretation, and judgments they attach to events and conditions; and their beliefs about cause-and-effect relationships in the political world and, hence, their expectations about how others will respond to their own behaviour." 105 This subjective comprehension and articulation of interests is not only internal to sentient agents. As Béland writes, "ideational process can help actors make sense of their perceived interests," but also help in convincing "the general public and specific interest group that the existing state of affairs is inherently flawed, and that major reforms are necessary to solve the perceived problems of the day, which are largely ideational constructions themselves."106 As Parsons defines, "Ideas are subjective claim about descriptions of the world, causal relationships, or the normative legitimacy of certain actions," and therefore they also depict social and political constructions of legitimate policy actions that put constraints on policymakers. ${ }^{107}$

While constructing discursive institutionalism, Vivien Schmidt combines the work of Peter Hall and John Campbell and sees ideas to exist at three levels - policies, programmes and

${ }^{103}$ Hay, C., 2006: 64

${ }^{104}$ Sikkink, K. Ideas and Institutions: Developmentalism in Brazil and Argentina (Cornell: Cornell University Press, 1991): 243

${ }^{105}$ Lieberman, Robert C., 2002: 697

${ }^{106}$ Béland, D., 2010: 148

${ }^{107}$ Parsons, C., "Showing Ideas as Causes: The Origins of the European Union," International Organization, Vol. 56, No. 1 (2002): 48 
philosophies - and categorise them, at each level, into two types of ideas - cognitive [constitutive of interests] and normative [which appeal to values]. ${ }^{108}$ She does not ascribe to particular titles for the two types of ideas at three levels and, rather, provides their descriptive understanding. She talks of cognitive ideas at policy level to offer solutions to the problem at hand, at the programmatic level to define the problem to be solved and identify the methods by which to solve them and finally at the philosophical level to mesh solution and definition of problems with deeper core of principles and norms of relevant scientific disciplines or technical practice. Similarly, normative ideas at the policy and programme levels meet the aspiration and ideals of the general public and at the philosophical level resonate with a deeper core of principles and norms of public life. ${ }^{109}$ Instead of seeing ideas in the background of policy debates or located in the foreground as Campbell distinguishes them in his typology, Schmidt instead talks of "background ideational abilities" that are internal to agents for creating and maintaining institutions and "foreground discursive abilities" for communicating to change or persist with those institutions. The synthesis provided by Schmidt on different types and levels of ideas combines distinctions that are rarely contested in study of ideas and their effect on public policy outcomes. ${ }^{110}$ More so, Schmidt's typology does not discount the role of interests as she sees agent's ideas also as response to "material (and not so material) realities, which affect them including material events and pressures."111 Rather than making a distinction between the two, Schmidt's typology mixes the instrumental and material dimensions of ideas and writes cognitive ideas to "provide the recipes, guidelines, and maps for political action and serve to justify policies and programs by

\footnotetext{
108 Schmidt, Vivian A., 2008: 303, 321

109 Ibid, 307

${ }^{110}$ Wentzel, J., An Imperative to Adjust: Skill Formation in England and Germany (Heidelberg: Springer, 2011): 33; Allmendinger, P., New Labour and Planning: From New Right to New Left (Abingdon, Oxon: Routledge, 2011): 46

${ }^{111}$ Schmidt, Vivian A., "Discursive Institutionalism," in Frank Fischer and Herbert Gottweis (eds.) The Argumentative Turn Revisited: Public Policy as Communicative Practice (Durham: Duke University press, 2012): 86-7
} 
speaking to their interest-based logic and necessity." This does little in bringing clarity to different types of ideas when cognitive ideas are seen to "provide robust solutions" as well as be "constitutive of interests." This essentially implies advancing the agenda beyond its typical distinction between normative and cognitive ideas and clearly distinguishing instrumental, material and values dimensions of ideas from one and other. Corina Barbaros distinguishes between these three dimensions of ideas: ${ }^{12}$

"Ideas may have, primarily, a cognitive character being descriptions of social political, economic situations and tools for understanding how things work. Moreover, ideas can have a normative nature which consists in ideals, values and norms that define what is good or bad. A third category of ideas that are currently distinguished regards the desires that form people's preferences (together with the cognitive and normative ideas)."113

Barbaros makes a strong case to support her assertion that it is ideas that are engine of history "and not structures, processes or interests." ${ }^{114}$ Referring back to Campbell's typology with this belief that ideas create interests, a material dimension could be added in addition to the two levels of normative and cognitive ideas. Campbell's first dimension consists of cognitive ideas that specify causal relationships and the second dimension is of normative ideas, which specifies how things ought to be. The second dimension composed of locus of the debate, whether it is at the foreground or in the background of the policy debate. Campbell concedes that there is slippage between cognitive and normative ideas and between foreground and

\footnotetext{
${ }^{112}$ Barbaros, C., "Do Issues Decide: Thematic and Partisan Ideational Strategies in Electoral Debates," Argumentum: Journal the Seminar of Discursive Logic, Vol. 10, No. 2 (2012): 113-132

${ }^{113}$ Ibid, 114

${ }^{114}$ Ibid, 118
} 
background ideas and those in the background may shift into the foreground over time. ${ }^{115} \mathrm{He}$ further argues, "The two dimensions from which the four types are derived are probably more akin to continua than to rigid dichotomies.” Building on these lines, another dimension material - is added to Campbell's typology. The material level at the foreground of the policy debate will be composed of 'contested interests' as social and political constructions, which give legitimacy to certain actions over others, and constituted of 'private interests' in the background, which are conceptions of self-interests when policies are conceived and decided upon (see table 3.1).

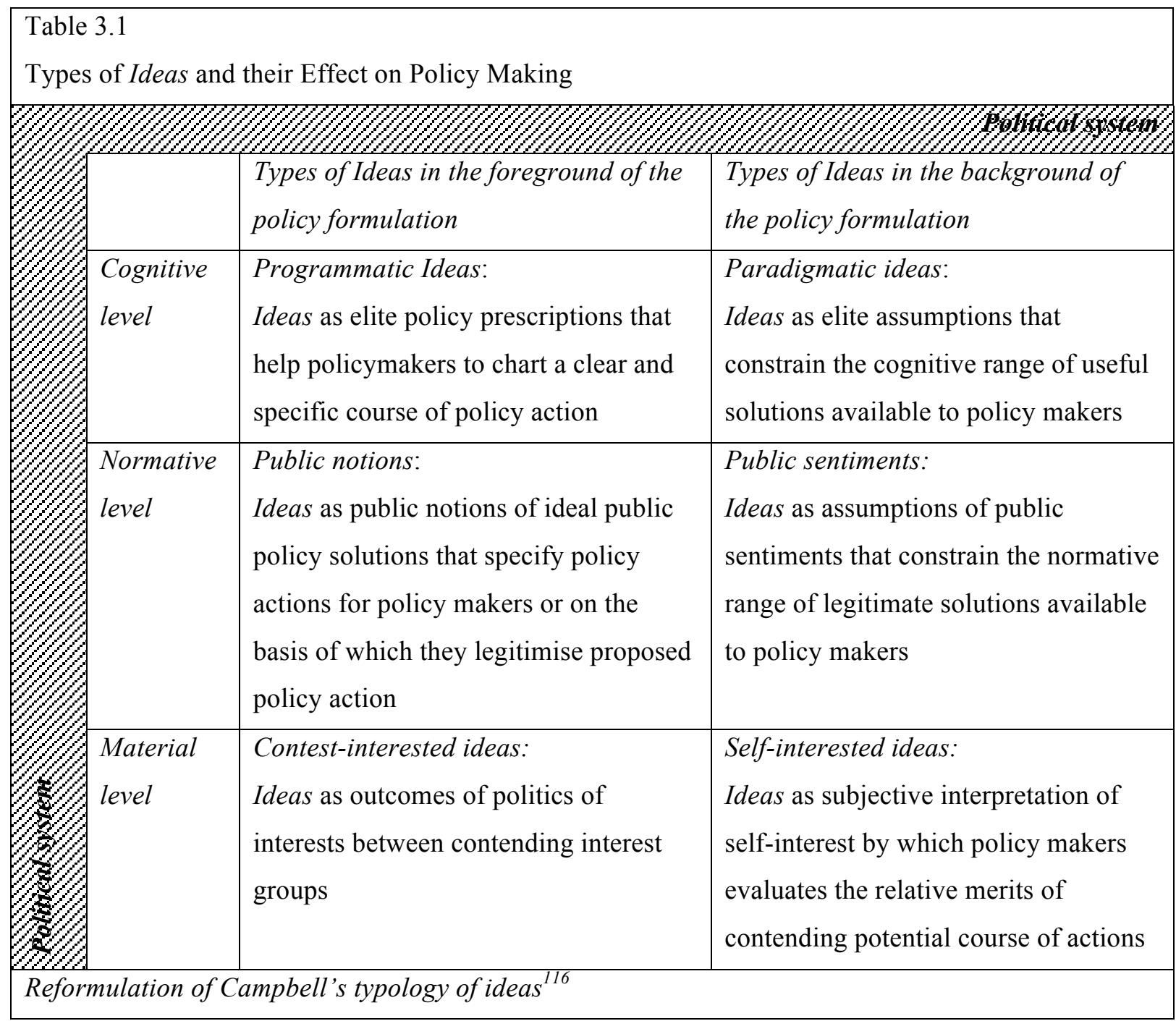

${ }^{115}$ Campbell, John L., 2008: 167

${ }^{116}$ Campbell, John L., 1998: 385 
Ideas as programmes and paradigms at the cognitive level of the typology, which entails the instrumental dimension of public policy making, are defined as:

Programmatic ideas sit at the foreground of the policy debate helping actors, as Campbell defines, "to devise concrete solutions to their policy problems." These not only specify cause-and-effect relationships but also prescribe a precise course of policy action a policymaker could take to address the problem in hand. ${ }^{117}$ Once institutionalised they constrain actions of policymakers by limiting their range of options but also become enabling structures when a new set of programmatic ideas comes to the fore contesting and [possibly] taking over the existing one.

Paradigmatic ideas reside in the background of the policy debate yet exerting influence over the shape of programmatic ideas and thereby revealing their own nature. These are "underlying theoretical and ontological assumptions about how the world works." They, in general, constrain actors on the range of solutions perceived and deemed useful for solving problems but are susceptible to change. ${ }^{118}$ Change in programmatic ideas is akin to the first- and second-order changes of Peter Hall where either the settings or the techniques of policy instruments are replaced, while transformation in paradigmatic ideas corresponds to the third-order change where the overarching goals, the techniques, and the precise settings are all altered.

At the normative level, ideas as frames and public sentiments appeal to the 'value' dimension of policy making and defined as:

\footnotetext{
${ }^{117}$ Ibid, 386

118 Ibid, 389
} 
Internal to sentient agents, ideas as public sentiments reside in the background of the policy debate but institutionalised through "broad-based attitudes and normative assumptions about what is desirable or not" and are dispersed over a large section of the polity. ${ }^{119}$ They essentially put constraints over actor's range of solution as to what is politically acceptable or unacceptable in relation to a particular policy problem. Once public sentiments starts overweighing paradigmatic ideas, they usually supersede the instrumental dimension of policymaking and even practically viable solutions are rendered politically unacceptable. Its transformation, therefore, influence the shape of the instrumental dimension of ideas than the other way round. Change in public sentiments is rare than the paradigmatic ideas and can potentially lead to the third-order change in policymaking, altering the entire schema consisting of the overarching goal, techniques and precise settings.

According to Campbell, ideas as frames are the repertoires of "symbols and concepts with which [actors] frame solutions to policy problems in normatively acceptable terms." ${ }^{120}$ For Campbell, ideas as frames are built upon public sentiments and underscore the same 'value' dimension when presented by policymakers to win over public support for policy proposals. Frames, in this sense, are conscious constructs, as appose to public sentiments, and conveyed through what Schmidt has called "communicative discourse between political actors and the public." ${ }^{121}$ Framing Ideas is most effective when it is based upon public sentiments and makes the case for programmatic ideas. But it does not imply that framing always originate from public

${ }^{119}$ Ibid, 392

${ }^{120}$ Ibid, 394

${ }^{121}$ Schmidt, Vivien A., 2008: 303; on similar argument also see: Wentzel, J., 2011:32 
sentiments, they may also carry the semblance of protecting the value dimension. Framing may also be reversed taking shape of popular public notions of ideal solutions influencing public policy outcomes or even the articulation of public sentiments and therefore it is referred here as public notions which could be symbols and concepts that help policy makers to legitimise policy solutions to the public, as per their perceptions of public sentiments, and they could also take form of popular public notions of ideal policy solutions. In settings where the instrumental dimension is stronger than the value dimension, framing ideas may not play significant role in shaping public-policy outcomes. On the other hand, public sentiments constrain policymakers in available solutions and framing enable them to bring-in the first and second-order changes in policy techniques and instruments. Reverse framing, however, could lead to a third-order change.

The third dimension added to Campbell's typology is composed of material considerations that are equally at the forefront and in the background of the policy debates and consists of contest-interested ideas or self-interested ideas:

Contest-interested ideas are at the foreground of the policy debates and result from competition and bargaining of interest groups for favourable public-policy outcomes. Interest groups that are able to muster sufficient support and mobilisation of resources have the results to their favour. As in the interest group theory of politics, actors play the role of brokers but while they consider different public-policy options they also seek to maximise their own material interests, i.e. re-election, which themselves are shaped by the wrangling of different interest groups. Contest-interested ideas put constraint on actors and resultant public-policy outcomes are beneficial to some but 
harmful to others. ${ }^{122}$ Moreover, they usually bring first- or second-order changes to policymaking where either the technique or the precise setting is altered.

Ideas as self-interest are the results of actor's subjective interpretation of their material realities. In contrast with contested interest, ideas as self-interests are shaped and reside in the background of the policy debates and herein actor's prime objective is pursuit of selfish objectives. Similarly, while in contested interests citizenry can still influence public-policy outcomes being members and representatives of different interests groups, self-interested ideas offer no meaningful place for citizens and communities. ${ }^{123}$ Policies that are made out of self-interested ideas place instrumental dimension second to the material dimension and, therefore policy outcomes may not represent viable or best-suited solutions available to policymaker. However, selfinterested ideas may also overlap with public sentiments or the paradigmatic ideas and where public or elite assumptions of useful solutions are also in the best interest of the policymaker.

Importantly, the three dimensions do not operate in a vacuum but within a political system. The political system has an effect on how the three dimensions operate while, in response, its outcomes influence the institutional makeup under which the political system is operating. The impact of political system on policy performance has been a major research question in studies of advanced democracies. ${ }^{124}$ In Patterns of Democracy - Lijphart makes the case that

\footnotetext{
${ }^{122}$ Moe, Terry M., "Power and Political Institutions," Perspectives on Politics, Vol. 3, No. 2 (2005): 216

${ }^{123}$ Hogler, R. and Gross, Michael A., "Journal Ranking and Academic Research: Two Discourses About the Quality of Faculty Work," Management Communication Quarterly, Vol. 23, No. 1 (2009): 13

${ }^{124}$ Jahn, D., and Müller-Rommel, F., "Political Institutions and Policy Performance: A Comparative Analysis of Central and Eastern Europe," Journal of Public Policy, Vol. 30, No. 1 (2010): 23 - 44
} 
the type of democracy has an impact on the policy outcomes. ${ }^{125}$ Since his seminal work, there is a plenty of literature making a similar argument that political systems causes variations in public attitudes and outcomes of social or economic policies. ${ }^{126}$ The theoretical reasoning for a particular regime type to have an effect on provision of public good is straightforward. In democracies, Truex explains, elected leaders place greater heed to popular demands to garner support for the next elections and, in contrast, authoritarian rulers prefer to buy support by distributing private rents. ${ }^{127}$ Besley and Case, for instance, argue that " $[\mathrm{t}]$ here can be little doubt that the structure of political representation, the terms on which elections are fought, and the rules governing the policy process, all influence policy outcomes." Sloan, in his comparative study of democratic performances of Latin American countries, arrives at a similar conclusion that "a political system that structures itself into a particular type of regime can supposedly develop the capabilities to accomplish some policy goals better than others." ${ }^{\prime 29}$ Sloan, in an earlier article together with Tedin, had arrived at a conclusion that that regime type is associated with public policy outcomes. Their evidence suggests that democratic regimes, for instance, are more flexible and capable of shifting policy priorities. $^{130}$

While there is a growing body of published empirical evidence showing a democratic advantage in public good provision, this assertion is not without criticism. Truex own analysis leads him to the conclusion that " $[\mathrm{t}]$ he inference that democracy is associated with

\footnotetext{
${ }^{125}$ Lijphart, A., Pattern of Democracy, (New Haven: Yale University Press, 1999)

${ }^{126}$ Armingeon, K., "The Effects of Negotiation Democracy: A Comparative Analysis," European Journal of Political Research, Vol. 41 (2002): 81 - 105

${ }^{127}$ Truex, R., "The Myth of the Democratic Advantage," Studies in Comparative International Development, 2015, DOI 10.1007/s12116-015-9192-4

${ }^{128}$ Besley, T., and Case, A., "Political Institutions and Policy Choices: Evidence from the United States," Journal of Economic Literature, Vol. 41 (2003): 67

${ }^{129}$ Sloan, John W., "The Policy Capabilities of Democratic Regimes in Latin America," Latin American Research Review, Vol. 24, No. 2 (1989): 124

${ }^{130}$ Sloan, J. and Tedin, Kent L., "The Consequence of Regime Type for Public Policy Outputs," Comparative Political Studies, Vol. 20, No. 1 (1987): 98 - 124
} 
better governance on these metrics is simply too fragile to be believed."131 Remmer evaluated the policy impact of military regimes in Latin America and comes to a conclusion that “empirical studies have failed to establish any strong relationship between regime type and public policy in Latin America." "132 In a subsequent article Remmer conjectures that in order to enable analysis of the impact of regime type on public policy outcomes, the regime needs conceptualization both in terms of competitiveness and inclusiveness. For Remmer, such an understanding can enable better analysis of the causes and consequences of regime similarities and differences and its implications on public policy outcomes. ${ }^{133}$ The work of Jahn and Müller-Rommel, on the other hand, extends the original argument by showing that "policy output not only depends on institutional settings and political actors but also is determined by the historical development of a country (path dependency) and international factors." 134 While there have been contending studies on how best the influence of regime type on policy outcomes can be determined, there is, as Besley and Case put it, "little doubt that the structure of political representation, the terms on which elections are fought, and the rules governing the policy process, all influence policy outcomes." ${ }^{\prime 135}$

The scholarship on what influence, if any, a particular regime type has on policymaking systems, i.e. origin and the process of policymaking, and not on the policy outcomes and their performance is still in a nascent stage. ${ }^{136}$ Modern political science, as Cuzán argues, has

\footnotetext{
${ }^{131}$ Truex, R., 2015

132 Remmer, Karen L., "Evaluating the Policy Impact of Military Regimes in Latin America," Latin American Research Review, Vol. 13, No. 2 (1978): 50

${ }^{133}$ Remmer, Karen L., "Exclusionary Democracy," Studies in Comparative International Development, Vol. 20, No. 4 (1985): $64-85$

134 Jahn, D., and Müller-Rommel, F., 2010: 39

135 Besley, T. and Case, A., "Political Institutions and Policy Choices: Evidence from the United States," Journal of Economic Literature, Vol. 41, No. 1 (2003): 67

${ }^{136}$ Peters, B. Guy, "The Policy Process in Developed and Less Developed Political System," International Journal of Public Administration, Vol. 19, No. 9 (1996): 1639
} 
mostly sought to establish linkages between regime type and public policy outputs. ${ }^{137} \mathrm{Jahn}$ and Muller-Rommel agree that in studies of advanced democracies the impact of political institutions on policy performance has been a major research question. ${ }^{138}$ In this research, it is conjectured that the political system has an impact on ideation and dynamics around the three dimensions.

This research defines a political system in a minimalist term and in lines with the concept of polyarchy introduced by Robert Dahl. In polyarchy, Dahl proposes that all political systems can be placed on the two dimensions of contestation and inclusiveness. Dahl describes contestation when citizens have unimpaired opportunities to formulate their preferences, signify their preferences to their fellow citizens and the government by individual and collective action and have their preferences weighed equally in the conduct of the government. Inclusiveness for Dahl is variation in the proportion of the population entitled to participate on a more or less equal plane in controlling and contesting the conduct of the government. ${ }^{139}$ Karen L. Remmer uses the two-dimensional classification of Dahl for defining the constituting elements of a political system. ${ }^{140}$ Remmer falls short of coining the term "grey-zone," but was acutely aware of this predicament in regime classification. She writes, “....actual regimes do not conform neatly to any of the extreme types ... the majority of regimes fall somewhere between the extremes." She agues, "The classificatory terminology typically applied to regimes obscures this point, leading to endless disputes," and that "Dahl's two-dimensional conceptualization of regime type can [locate all regimes] within its parameters." In further defence of Dahl's regime classification she contends, "By

${ }^{137}$ Cuzán, Alfred G., “An Analysis of Regime Type in Iberoamerica: 1973-1983,” Journal of Developing Societies, Vol. 4, No. 2 (1988): 180

${ }_{138}$ Jahn, D. and Muller-Rommel, F., "Political Institution and Policy Performance: A Comparative Analysis of Central and Eastern Europe," Journal of Public Policy, Vol. 30, No. 1 (2010): 23

${ }^{139}$ Dahl, Robert A., Polyarchy: Participation and Opposition (New Heaven: Yale University Press, 1971): $2-4$

${ }^{140}$ Remmer, Karen L., 1985: 69 
conceptualizing regime type in terms of two intersecting continua, the scheme also takes us away from the enormous confusion that has resulted from the definition of regime types in terms of syndromes of interrelated traits." ${ }^{\prime 14}$ Coppedge et al come to a conclusion in their analysis of eleven different streams of evidence that "about three-quarters of what Polity, Freedom House, and other indicators of democracy have been measuring consists of variation on the two dimensions of democracy that Robert Dahl proposed in Polyarchy - contestation and inclusiveness."142 The two-dimensional classification of polyarchy, which is Dahl's term for real-world approximation of true democracy, has become one of the most familiar standards for democracy. ${ }^{143}$

The proposed typology of ideas brings together the instrumental, value and material dimensions of policymaking, in a particular political system, together in one analytical framework. It rejects the analytical distinction drawn between ideas and interests as determinants of policy, but rather considers ones desires, preferences and motivations as ideational articulation. It has the potential of cross-fertilisation between the rational-choice theory that implies actors operate according to a self-interested cost-benefit analysis and those theoretical perspectives questioning this assumption. By further refining the concept of ideas and their affect on policymaking, it also has the ability to bring out the new institutionalist scholarship from its quagmire of being seen merely as a theory of constraint, limiting the range of possible solutions for policymakers, but also as the one where it has the explanatory power for institutional change and offers as well the theory of action.

\section{4: CONCLUDING WORDS}

${ }^{141}$ Ibid

${ }^{142}$ Coppedge, M., Alvarez, A. and Maldonado, C., "Two Persistent Dimensions of Democracy: Contestation and Inclusiveness," The Journal of Politics, Vol. 70, No. 3 (2008), $632-647$

${ }^{143}$ Ibid, 632 
The institutionalist argument, Blyth argues, is ultimately concerned with how order is created and maintained and how change is possible. By giving supremacy to ideas into institutional analysis, institutionalists can now investigate both the path of institutional change and the origins of change itself. ${ }^{144}$ While it may be argued that the ideational scholarship is still very much a work in progress and lacks a coherent school-of-thought but recent theoretical advancements have built enough foundation on which institutional analysis could be sufficiently carried out. It started as an explanatory variable to theoretical dead-ends, albeit different, of the three established new institutionalisms but has amassed a distinct body of its own overcoming not only their weaknesses but also bridging gaps amongst them for a wellrounded analysis of policymaking outcomes. This paper highlights some fundamental differences amongst ideational scholars in their ontological and epistemological assumptions towards the role of ideas. The debate over the casual nature of ideas and their extent, therefore, is likely to continue. The next important step in sharpening the debate, as Tannenwald states would be "to identify some tests and causal mechanisms ... that are valid across a range of approaches." ${ }^{\prime 45}$ Tannenwald links causal mechanism to four specific stages in the lifecycle of ideas, namely their origin and production, transmission, reception and the implementation. ${ }^{146}$ This categorisation is helpful in increasing the precision of causal claims about the autonomy and supremacy of ideas in institutional analysis but yet ignores some key stages of a lifecycle, which may or may not exist but remain central to the understanding institutional change, i.e. reproduction, diffusion and supplanting of ideas to give-in to a new set of ideas. Nevertheless, the lifecycle analysis allows triangulation of ideas with the different stage of policy process, e.g. from problem identification and definition to adoption

\footnotetext{
${ }^{144}$ See: Blyth, Mark M., 1997

${ }^{145}$ Tannenwald, N., 2005: 42

${ }^{146}$ Ibid, 30
} 
and implementation of policy, and thus could be instrumental in further advancing the ideational analysis. The next chapter aims at brining further theoretical advancements to the concept of ideas and its affects on policy outcomes by looking specifically into origin of ideas and mechanism by which it affects decision-making for comprehensively laying out the overall research design and methodology. 



\section{IDEAS AND THE METHODOLOGICAL APPROACH OF 'POLICY AS DISCOURSE'}

\section{1: INTRODUCTION}

ohn Campbell in an article published in 1998 asserted that scholarship in ideational
institutionalism, a distinction at the time not yet given to the concept, was hampered
by two serious problems. First, it is poorly conceptualised and second it lacks empirical evidence to support the claim that ideas affect policy outcomes. It was the very first enquiry by Campbell on the subject. ${ }^{1}$ A decade later in 2008 Campbell conceded that when first encountered with the concept in 1993 he had failed "to consider the importance of discourse and ideas in shaping people's perception of their interests and strategic actions in the fist place." ${ }^{2}$ Campbell comes to understand ideas important in shaping policy outcomes and with interests being "just another type of idea." 3 He also recognised that there is a lot of work to be done to understand how ideas affect policymaking and institutional change. Campbell sums up the criticism on ideational institutionalism to be mainly around different types of ideas, their origin, and mechanisms by which they affect decision-making. ${ }^{4}$ The criticism around different types of ideas and their affect on policymaking has already been

\footnotetext{
${ }^{1}$ Campbell, John L., "Institutional Analysis and the Role of Ideas in Political Economy," Theory and Society, Vol. 27, No. 3 (1998): 377

${ }^{2}$ Campbell, John L., "What do we Know - Or Not - About Ideas or Politics?" in Peter Nedergaard and John L. Campbell (eds.) Politics and Institutions (Copenhagen: DJOEF, 2008): 157

${ }^{3}$ Ibid, 158

${ }^{4}$ Ibid, $158-9$
} 
discussed in detail in the previous chapter in which Campbell's typology of ideas is also expanded to include the material dimension. The typology is further discussed in this chapter and presented as an "ideational framework of public policy." The purpose of this chapter is to further advance the concept of ideational institutionalism by looking into the origin of ideas and the mechanism by which they affect policy outcomes. Together with the analytical framework based on the types of ideas, the discussion and analysis in this chapter layouts, in detail, the research methodology for understanding the effect of ideas on public policy process and its outcomes.

In the previous chapter, the issue of conceptual clarity of the role of ideas in policy process and its outcomes were discussed in detail. In this chapter, first the critique is provided of existing concepts and theories that have discussed mechanisms through which ideas originate and affect policy outcomes. A case is built in Section 3 for a methodological approach of 'policy as discourse' that draws attention to the role of discursive practices and meanings in shaping policies. In Section 4, the analytical framework on types of ideas is revisited and presented as an "ideational framework of public policy" to discern the role of ideas in public policy process and its outcomes. The Section also postulates key claims of this research, presented as working hypotheses. Section 5 addresses some of the fundamental methodological concerns when research projects on developing public policy theories are embarked upon. Some final thoughts are offered in Section 6 to conclude the chapter.

\section{2: ORIGIN OF IDEAS}

In new institutionalism, there is already a substantial inquiry on the origin of ideas. Before these concepts and theories are discussed it is important to underscore a few important 
considerations. First, public policy outcomes are often the result of complex processes and interplay of variables at various levels whereas existing models focus on one aspect or some part of the overall dynamics. Therefore, they either do not provide the whole picture or suffer from their inability to have general applicability. ${ }^{5}$ Second, as discussed in detail in the previous chapter, the relationship between ideas and interests and the understanding that interests are just another type of ideas is equally important in any theoretical discussion on public policy outcomes. Paul Cairney makes the case in point and writes, "Attempts to separate analytically [interests from ideas] ...may paint a misleading picture." ${ }^{\prime 6}$ Third, ideas when form the basis of different models and theories of public policy outcomes, they are either treated as independent variable having force of their own or, in contrast, discussed being dependent on their construction and promotion by various actors. This distinction is unhelpful and leads public policy analysis into a quagmire where ideas are either reduced to constraints on agents, as is the case in historical institutionalism, or incapacitated in explaining situations having multiple equilibria as in rational choice institutionalism. ${ }^{7}$ In view of these considerations and starting with the historical institutionalism, this section provides critique of major theories and models of public policy outcomes based on the concept of ideas within the new institutionalism scholarship.

The concept of social learning, originated in the work of Albert Bandura, is among the most established concepts in historical institutionalism. It points to the process through which policymakers learn and adjust their ideas and practices to changes in their environment, which also manifest in their policymaking. This is also the basis of Peter Hall's work on policy paradigms. A seminal study conducted by Huge Heclo in 1974 suggests that 'political

\footnotetext{
${ }^{5}$ Cairney, P. Understanding Public Policy: Theories and Issues (New York: Palgrave Macmillan, 2012): 287

${ }^{6}$ Ibid, 242

${ }^{7}$ Ibid, 221
} 
learning' is a governmental response to some kind of social and environmental stimulus. ${ }^{8}$ Hall himself defines social learning "as a deliberate attempt to adjust the goals or techniques of policy in response to past experience and new information. Learning is indicated when policy changes as the result of such a process." ${ }^{.9}$ Also originating from historical institutionalism, political process has been described as path dependent. Pierson defines path dependency as a "social process grounded in a dynamic of increasing returns." ${ }^{10} \mathrm{He}$ conjectures that "an investigation of path dependence can provide a basis for developing important hypotheses about the sources of political stability and change." $" 11$ These and similar concepts, though, have made important contribution towards advancing the scholarship but are plagued from criticism generally abhorred on historical institutionalism. Social learning inherently implies institutions to have a deterministic role and, therefore, serving primarily as constraints on individuals' actions and their preferences forming by institutional context in which they calculate their interests. Institutional change is explained through exogenous shocks, dramatic events or crises situation and ideas are used only as addendum to overcome theoretical dead-ends. ${ }^{12}$

In political science and in comparative policy studies, the concept of policy convergence is becoming increasingly popular, which suggests a "tendency of societies to grow more alike to develop similarities in structures, processes and performances." ${ }^{, 13}$ Bennett argues that policy convergence may imply one of five things; convergence of goals, content, instrument,

\footnotetext{
${ }^{8}$ Heclo, H. Modern Social Politics in Britain and Sweden (New Haven: Yale University Press, 1974): $305-6$

${ }^{9}$ Hall, Peter A., 1993: 278

${ }^{10}$ Pierson, P., "Increasing Returns, Path Dependence, and the Study of Politics," American Political Science Review, Vol. 94, No. 2 (2000): 251

${ }^{11}$ Ibid, 264

${ }^{12}$ Krasner, S., "Approaches to the State: Alternative Conceptions and Historical Dynamics," Comparative Politics, Vol. 16 (1984): 223 - 246

${ }^{13}$ Kerr, C., The Future of Industrial Societies: Convergence or Continuing Diversity? (Cambridge: Harvard University Press, 1983): 3
} 
outcomes or style of policy. He identifies four frameworks of processes through which convergence might arise, namely emulation where policies are copied from implemented elsewhere, elite networking where transnational communities of policy makers converge on polices, harmonisation through the work of international actors and penetration into policymaking by external actors and interests. ${ }^{14}$ Carafa, in her analysis, brings in the concept of policy diffusion into the discussion on policy convergence to bridge the gap between the two. He defines policy diffusion "as a process through which ideas spread across time and space... mediated by a broad range of mechanisms and channels of influence between countries, varying from the imposition of policies, international binding norms and regulatory harmonisation, to voluntary adoption of foreign policy models." ${ }^{15}$ Berry and Berry make a the same case, through their research on state lottery adoption, that diffusion has an influence in a region whereby states, when confronted with policy problems, emulate their neighbours for solution. ${ }^{16}$ Campbell, however, argues that theories emanating from historical institutionalism are generally better in explaining institutional reproduction and stability as they, by and large, based on the concept of path dependency. ${ }^{17}$ In order to explain institutional change, Campbell presents the concepts of bricolage and translation, which he describes as "a process by which institutions change may involve the rearrangement or recombination of institutional principles and practices in new and creative way, or similarly the blending of new elements into already existing institutional arrangements," the form he

\footnotetext{
${ }^{14}$ See: Bennett, Colin J., "Review Article: What is Policy Convergence and what causes it?" British Journal of Political Science, Vol. 21, No. 2 (1991): 215 - 33

${ }^{15}$ Carafa, L., "When the Birds Fly Together. A Framework for Analysing International and Domestic Factors Behind Policy Diffusion and Convergence," paper presented at the Italian Political Science Association Twenty-third Annual Conference, Rome, Italy, 17 - 19 September 2009

${ }^{16}$ Berry, Frances S. and Berry, William D., "State Lottery Adoption as Policy Innovations: An Event History Analysis," The American Political Science Review, Vol. 84, No. 2 (1990): 395 - 415

${ }^{17}$ Campbell, John L., "Institutional Reproduction and Change," (87 - 115) in Glenn Morgan, John L. Campbell, Colin Crouch, Ove Kaj Pederson and Richard Whitley (eds.), The Oxford Handbook of Comparative Institutional Analysis (Oxford: Oxford University Press, 2010): 88
} 
calls the process of bricolage and the latter as translation. ${ }^{18}$ At the macro level, Campbell explains, bricolage refers to a process where the range of alternative institutional models that had been tried or advocated previously in a certain location are considered in order to understand the range of historically given alternatives that entrepreneurs might put in use in the future. ${ }^{19}$ A similar concept but implying intentional activity is of policy framing whereby policy actors, when confronted with a problem, create understand and make sense of the situation and then act according to the prescription. The framing process is described as a deliberate activity on the part of the policy actor aimed at generating public support for specific policy ideas. ${ }^{20}$ The increasing scope and intensity in the study and practice of different theories and models of policy transfer coincides with the advent of the digital era and, as a result, dramatic changes of the last two decades in global communication, political and economic institutional structures and to the nation states themselves. ${ }^{21}$ This particular set of theories, no doubt, is an important advancement to the study of institutionalism whose static and liner assumptions could not account for the profound political changes of the last decade of the twentieth century. But to fully function these theories rely on the demand side's perceived need for change and the supply side's availability of viable solution, for an institutional change to occur. ${ }^{22}$ Moreover and besides several demand- and supply-side constraints with which the process of policy transfer may not fully mature, these theories are nonstarter in cases where policies originate locally or have indigenous roots and also in subject matters whose orientation is innovative or unique. ${ }^{23}$ It is then the subject of analysis whether policy transference has occurred or not and if it has and as Evans comes to the

\footnotetext{
${ }^{18}$ Ibid, 99

${ }^{19}$ Ibid, 100

${ }^{20}$ Béland, D., "Ideas and Social Policy: An Institutional Perspective," Social Policy and Administration, Vol. 39, No. 1 (2005): 11

${ }^{21}$ Evans, M., "Policy Transfer in Critical Perspective," Policy Studies, Vol. 30, No. 3 (2009): 243

${ }^{22}$ Weyland, K., "Toward a New Theory of Institutional Change," World Politics, Vol. 60, No. 2 (2008): 284

${ }^{23}$ Evans. M., Policy Transfer in Global Perspective (Burlington, Ashgate Publishing, 2004): 40
} 
conclusion that "one might then determine the degree of transfer - copying, emulation, hybridisation, or inspiration." 24

The third set of theoretical models has in common in their analysis a more central and elevated position given to agency than in either the organisational or historical institutionalisms. As a result, it is argued, that such models provide a more "balanced assessment of the ideational foundations of action and constraint." 25 The theory of agenda setting [also called multiple streams analysis], as presented by John Kingdon, is one such actor-centred theory that looks into the impact of ideas on policy outcomes. Kingdon describes the concept of agenda as "the list of subjects or problems to which governmental officials, and people outside of government closely associated with those officials, are paying some serious attention at any given time," and where the list also contains "policy options available to solve these problems". ${ }^{26}$ The model of agenda setting essentially consists of three streams. The first is the problem stream referring to the selection of issues that are considered significant social and economic problems. The second stream is of policy, which contains alternatives and paradigms, to which Kingdon refers as 'policy primeval soup' containing policy ideas floating around and combined with one another in various ways. ${ }^{27}$ The political stream of Kingdon's model refers to framing used by policy entrepreneurs to bring forth their favoured solutions with a recognised social and economic problem to affect political decisions. ${ }^{28}$ A related concept is of epistemic communities, refined by Peter Hass, which refers to a network of policy experts that exercise influence by interpreting complex problems and recommend possible response to policymakers due to their authoritative claim

\footnotetext{
${ }^{24}$ Ibid, 41

${ }^{25}$ Campbell, John L., 1998: 399

${ }^{26}$ Kingdon, John W., Agendas, Alternatives, and Public Policies (New York: HarperCollins. 1995): 3 $-4$

${ }^{27}$ Ibid, 117

${ }^{28}$ Ibid, 122
} 
to policy-relevant knowledge and experience. Hass explains the role of epistemic communities as "articulating the cause-and-effect relationships of complex problems, helping states identify their interests, framing the issues for collective debate, proposing specific policies, and identifying salient points for negotiation." He describes epistemic community as "a network of professionals with recognised expertise and competence in a particular domain and an authoritative claim to policy-relevant knowledge within that domain or issue-area." 29 For a network of professionals to be called an epistemic community, Hass argues, they must shared a set of normative and principled beliefs as well as causal beliefs together with the notions of validity and policy enterprise. He explains notions of validity as internally defined criteria for weighing and validating knowledge, policy enterprise as a set of common practices associated with a set of problems. ${ }^{30}$ Theories, such as epistemic community, agenda setting, pay more attention to how actors are involved in originating ideas and give more credence to agency. They also portray a more dynamic understanding of institutional scholarship where, importantly, they are not only seen as constraining structures limiting the range of choices available to actors but also as enabling factors to which actors use to achieve their objectives. ${ }^{31}$ This set of models, however, depicts a multilayer and messy political process linked strongly to the US separation of power and holds little strength in centralised parliamentary systems or closed policymaking networks. ${ }^{32}$ They reject rational-choice theory altogether and are essentially interested into identifying, as Cairney writes, "successful adoption of one particular idea at the expense of many others within a political process characterised by," among others, ambiguity and competition. ${ }^{33}$

\footnotetext{
${ }^{29}$ Hass, Peter M., "Epistemic Communities and International Policy Coordination," International Organization, Vol. 46, No. 1 (1992): 2 - 3

${ }^{30}$ Ibid

${ }^{31}$ Campbell, John L., 2010: 108

${ }^{32}$ Cairney, P., 2012: 240

${ }^{33}$ Ibid
} 
In contrast to the three established new institutionalisms and their various extensions, agents in ideational understanding are sentient who not just operate or adapt to existing institutions but can also create and maintain new institutions through their ideational abilities. ${ }^{34}$ These sentient agents use ideas and discursive frames to legitimise the need to reform existing policies and institutions. Hall, referring to these discursive frames as political discourse, writes, "Politicians, officials, the spokesmen for social interests, and policy experts all operate within the terms of political discourse. ${ }^{, 35}$ For Schmidt also, ideas are conveyed interactively through discourse where the former becomes the substantive core of the later. She identifies two forms of discourse, the coordinative discourse among policy actors and the communicative discourse between political actors and the public. Schmidt, in ideational setting, describes discourse as "not just ideas or "text" (what is said) but also context (where, when, how, and why it was said)." Ideas, however, are not only the substantive core of a discourse or its context during an interactive process. They also function as cognitive filters, as Hay writes, “Through which actors come to interpret environmental signals... and conceptualise and assess their strategic conduct. ${ }^{, 36}$ Béland concurs with Hay and argues, “cognitive filter' concerns both self-perceptions and the framing processes that actors use to convince others that it is in their interest to mobilise with them in order to reach shared goals and have an impact on outcomes. ${ }^{, 37}$ Discourse is not merely an instrumental intentional means of information exchange. It also has constructive and interpretive abilities central to development and sustenance of shared meanings and common identity and an agent's own interpretations and actions within particular institutional setting. ${ }^{38}$ Discourse analysis would also enable a better understanding on how some ideas become prominent over others and

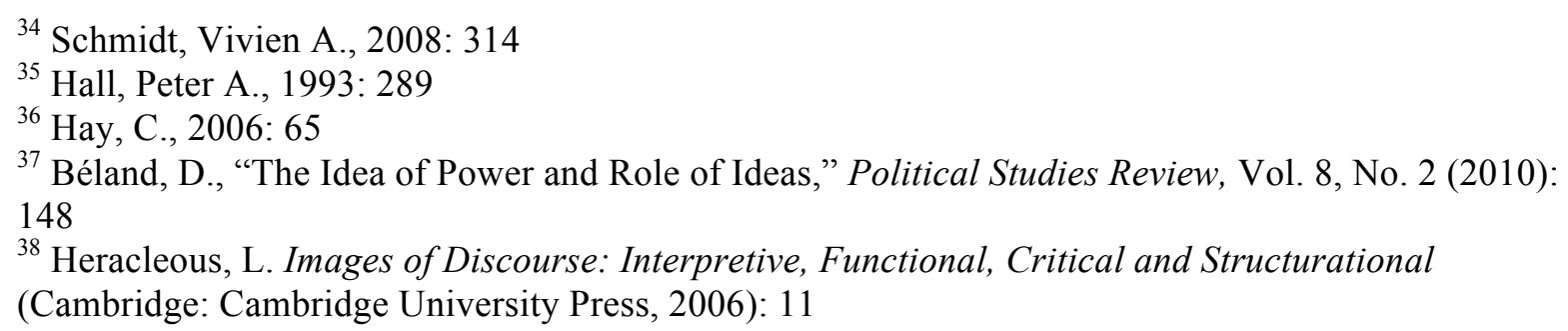


how do they cohere or collide. ${ }^{39}$ In policy studies, the methodological approach of 'policy as discourse' centres on the same lines and focuses on the discursive construction of policy problems and proposals and on the effects of the policies that accompany particular constructions. $^{40}$

\section{3: THE METHODOLOGICAL APPROACH OF 'POLICY AS DISCOURSE'}

By mid 1990s, there were already a number of theorists and researchers who essentially described 'policy as discourse. ${ }^{41}$ Carol Bacchi, one of the frontrunners to have taken up this approach to policy analysis, asserts that with such an understanding the implication is "that no one stands outside discourse. ${ }^{\prime 42}$ This particular viewpoint is based on the rejection of neopositivist and realist explanation that correspond to objective realities 'out there' in the world. ${ }^{43}$ The roots of the approach 'policy-as-discourse' are connected with post-empiricism, whose own theoretical development has been outside of policy studies, in particular social constructionism, critical theory, and post-structuralism. ${ }^{44}$ Its premise is based on the understanding, as Bacchi explains, that 'problems are 'created' or 'given shape' in the very

\footnotetext{
${ }^{39}$ Lieberman, Robert C., 2002: 700

${ }^{40}$ Bacchi, Carol L., Women, Policy and Politics: The Construction of Policy Problems (London: Sage, 1999): 48

${ }^{41}$ Ball, S. J., Politics and Policy Making in Education: Exploration in Policy Sociology (New York: Routledge, 1990); Ball, S. J., "What is Policy? Texts, Trajectories and Toolboxes," Discourse, Vol. 13, No. 2 (1993): 9 - 17; Goodwin, N., "Governmentality in the Queensland Department of Education: Policies and the Management of Schools," Discourse, Vol. 17, No. 1 (1996): 65 - 74; Phillips S. D., "Discourse, Identity and Voice," Feminist Contributions to Policy Studies," in L. Dobuzinskis, M. Howlett and D. Laycock (eds.) Policy Studies in Canada: The State of the Art (Toronto: University of Toronto Press, 1996); Torgerson, D., "Power and Insight in Policy Discourse: Post-positivism and Problem Definition," in L. Dobuzinskis, M. Howlett and D. Laycock (eds.) Policy Studies in Canada: The State of the Art (Toronto, University of Toronto Press, 1996); and Watts, R., "Government and Modernity: An Essay in Thinking Governmentality," Arena Journal, Vol. 2 (1993/94): 103 - 157

${ }^{42}$ Bacchi, C., "Policy as Discourse: What does it mean? Where does it get us?" Discourse: Studies in the Cultural Politics of Education, Vol. 21, No. 1 (2000): 45

${ }^{43}$ Fischer, F., Reframing Public Policy: Discursive Politics and Deliberative Practices (Oxford: Oxford University Press, 2003): 21

${ }^{44}$ Ibid, 21
} 
policy proposal that are offered as 'responses. ${ }^{45}$ The approach 'policy-as-discourse' starts from the assumption, writes Goodwin, that "all actions, objects and practices are socially meaningful and that the interpretation of meaning is shaped by the social and political struggle in specific socio-political context. ${ }^{, 46}$ Thus, both the policy process and its outcomes are cultural products and context specific. Theorists who subscribe to analysing 'policy-asdiscourse' draw on the work of Michel Foucault on the conceptualisation of discourse and apply it to policy. ${ }^{47}$ In Foucault's conception, discourse entails "practices that systematically form the objects of which they speak; they do not justify objects, they constitute them and in the practice of doing so conceal their own invention." 48 Before an attempt could be made to precisely defining the approach 'policy as discourse,' it is important to understand what exactly is meant by 'discourse' and how it links with the concept of ideas.

Bacchi argues that there is no single or correct definition of discourse as we define this term to suit our purpose. ${ }^{49}$ She writes, "The concept of discourse is notoriously difficult, not least because it means different things in different analytic traditions. ${ }^{, 50}$ Paul Bové agrees that one cannot provide definition of discourse and an attempt to do so "would be to contradict logic of the structure of thought in which the term "discourse" now has a newly powerful critical function." He maintains that "to force an answer [about meaning of discourse] would be, in advance, hopelessly to prejudice the case against understanding the function of "discourse" either in its post-structuralist context or in its existence as an institutionalised system for the

\footnotetext{
${ }^{45}$ Bacchi, C., 2000: 48

${ }^{46}$ Goodwin, S., "Women, Policy and Politics: Recasting Policy Studies," in Angelique Bletsas, Chris Beasley (eds.) Engaging with Carol Bacchi: Strategic Interventions and Exchanges (Adelaide: University of Adelaide Press, 2012): 29

${ }^{47}$ Grebe, C., Reconciliation Policy in Germany 1998-2008: Constructing the Problem of the

${ }^{48}$ Foucault, M., The archaeology of knowledge, A. M. Sheridan-Smith, (trans.) (London: Tavistock, 1972): 49

${ }^{49}$ Bacchi, Carol L., 1999: 55

${ }^{50}$ Bacchi, C., Analysing Policy: What's the Problem Represented to be? (Frenchs Forest, NSW:

Pearson Education, 2009): 35
} 
production of knowledge in regulated language." ${ }^{, 51}$ For Bové the right questions to ask then are how does discourse function, where is it to be found, and how does it exist. Stephen Ball, on the same lines, derives a functional definition from the work of Michel Foucault and describes discourse as "about what can be said and thought, but also about who can speak, when, where and with what authority." 52 Inhere too 'language' remains central to discourse. Hajer writes that language "has the capacity to make politics, to create signs and symbols that can shift power balance and that can impact on institutions and policy-making. ${ }^{, 53}$ The approach of 'policy as discourse' is, however, larger than language and draws attention to both the power of discourse and the power to make discourse. ${ }^{54}$ The approach of 'policy-asdiscourse' thus maintains that policy is a strategic and political process where no social actor stands outside the process and where there is deeper reflection on the contours of a particular policy discussion, the shape assigned to a particular problem. ${ }^{55}$

In policy studies, the aim of discourse analysis is to show how actions and objects come to be socially constructed and what they mean for social organisation and interaction. ${ }^{56} \mathrm{~A}$ "policyas-discourse' approach, as Shaw defines, would then be understood as an attempt to explain the means by which social processes and interactions shape different realities. ${ }^{57}$ Shaw further argues that conceptualising policy-as-discourse "offers opportunities for those with a vested

\footnotetext{
${ }^{51}$ Bové, P., "Discourse," in Frank Lentricchia, Thomas McLaughlin (eds.) Critical Terms for Literary Study (Chicago: University of Chicago Press, 1990): 53

${ }^{52}$ Ball, Stephen J., "Introducing Monsieur Foucault", in Stephen J. Ball (ed.) Foucault and Education: Disciplines and Knowledge (London: Routledge, 1990): 2

${ }^{53}$ Hajer, Maarten A., "Doing Discourse Analysis: Coalitions, Practices, Meaning," in Margo van den Brink and Tamara Metze (eds.) Words Matter in Policy and Planning: Discourse Theory and Method in the Social Sciences (Utrecht: Netherlands Graduate School of Urban and Regional Research, 2006): 67

${ }^{54}$ Bacchi, Carol L., 1999: 41

${ }^{55}$ Bacchi, Carol L., 1999: 49 - 50

${ }^{56}$ Fischer F., 2003: 73

${ }^{57}$ Shaw, Sara E., "Reaching the Parts that other Theories and Methods Can't Reach: How and Why a Policy-as-Discourse Approach Can Inform Health-related Policy," Health Vol. 14, No. 2 (2010): 200
} 
interest in policy to reach the parts that other theories and methods can't reach." ${ }^{, 58}$ Daugherty and Ecclestone make a similar case and argue that the notion of 'policy-as-discourse' enables researchers, practitioners and implementers of policy decisions to see how discourses in policy construct legitimise certain possibilities for thinking and acting while tacitly excluding others." 59 Phoenix argues that analytic focus on 'policy as discourse' can "enable deconstruction of the apparent neutrality and objectivity of the stories that sustain policies and the explicit or implicit rules that validate them." ${ }^{, 60}$ To view 'policy as discourse', Phoenix maintains, "highlights how policies are interlinked with ideas [emphasis added] about what is say-able and thinkable in particular contexts, which can have material effects on, for example, the distribution of resources." 61 The work of Hajer further highlights this interconnectivity between discourse and ideas when he conceives the former as "a specific ensemble of ideas, concepts, and categorisations that are produced, reproduced, and transformed in a particular set of practices and through which meaning is given to physical and social realities. ${ }^{, 62}$ If ideas are understood as the basis for policy decisions, they themselves are the product of discourse, which also serves as the communicative and coordinative vehicle for framing particular set of policy solutions above others.

\footnotetext{
${ }^{58}$ Ibid, 196

${ }^{59}$ Daugherty, R. and Ecclestone, K., "Constructing Assessment for Learning in the UK Policy Environment," in John Gardner (ed.) Assessment and Learning (London: Sage, 2006): 153; also see: Daugherty, R., "Mediating Academic Research: The Assessment Reform Group Experience," in John Furlong and Alis Oancea (eds.) Assessing Quality in Applied and Practice-based Research in Education (Abingdon, Oxon: Routledge, 2008): 24

${ }^{60}$ Phoenix, A., "Enabling Research? Silencing and recognition in social research," in Jerome Satterthwiate, Heather Piper and Pat Sikes (eds.) Power in the Academy (London: Trentham Books, 2009): 65

${ }^{61}$ Ibid

${ }^{62}$ Hajer, Maarten A., The Politics of Environmental Discourse (Oxford: Clarendon, 1995): 44
} 
The distinctive aspect of 'policy-as-discourse' approach is that it can both be understood as a research method and a political activity. ${ }^{63}$ Julia Black has made significant contribution to this subject within the realm of a broader theoretical debate on 'policy-as-discourse. ${ }^{64}$ Black in her article "Regulatory Conversations" constructs a methodological framework on these very lines and argues, "Regulation is in large part a communicative process [and] understanding such regulatory conversation is thus central to understanding the 'inner life' of that process. ${ }^{, 65}$ For Black, discourse analysis goes further than its communicative facet and is the basis of social action in that it is constitutive as in building objects, worlds, minds identities and social relations, functional as in designed to achieve certain ends and coordinative as in producing meaning and shared senses. ${ }^{66}$ Her main contention is that "discourse forms the basis of regulation." The methodological framework presented by Julia Black conceives discourse to have the ability to operate at instrumental, value and interest levels but also having multiple dimensions containing interactive, interpretative, constructive and coordinative facets. Black presents five contentions as to the relationship of discourse and social practices stemming from its abovementioned constitutive, functional and coordinative understanding.

The first contention relates to communicative interactions, which produces meaning and carries a dialectical relationship between language and agency. This implies that in policymaking process, norms will be interpreted in accordance with the strategies and pre-interpretive position of those whose behaviour they seek to change. This is also significant, as Black asserts, "in building meaning and to changing existing pre-

\footnotetext{
${ }^{63}$ Goodwin, S., "Analysing Policy as Discourse: Methodological Advances in Policy Analysis," in Lina Markauskaite, Peter Freebody and Jude Irwin (eds.) Methodological Choice and Design: Scholarship, Policy and Practice in Social and Educational Research (London: Springer, 2011): 168

${ }^{64}$ Black, J., "Regulatory Conversation," Journal of Law and Society, Vol. 29, No. 1 (2002): 163 - 96

${ }^{65}$ Ibid, $164-165$

${ }^{66}$ Ibid
} 
interpretations by creating new interpretive communities with a view, ultimately, to changing behaviours." ${ }^{67}$ This corresponds with the normative dimension of the proposed Ideational Framework of Public Policy where ideas take form of public sentiments at the background and as symbols and solution at the foreground of policy debate.

The second contention talks of positioning actors and constituting their identities through social communicative interactions. In relation to policymaking, identity matters because it affects how individuals and organisation are viewed. This contention is particularly relevant in positioning policy outcomes on different levels of ideational framework, not just in the perspective of policymakers but also in view of other actors who are involved in or to whom the policymaking process is aimed at.

The third contention concerns to the relationship between language, thought and knowledge. Here, knowledge refers to individual cognition whereas conversations are a central vehicle for the dissemination of knowledge. This contention relates to the discursive nature of the ideational process of defining problems and creating knowledge. This, as Black explains, "will enable us to better understand how and why different ideas, different sets of knowledge, become relevant at different points and at different times." 68 This contention refers to the cognitive level of the ideational framework and looks into individual cognition, particularly how knowledge and skills are acquired and disseminated and how it is utilised to govern and control the conduct of others or in identification of issues and for defining problems and interests.

\footnotetext{
${ }^{67}$ Ibid, $178-179$

${ }^{68}$ Ibid, 189
} 
The fourth contention is that language relates to power and this relationship shapes discursive practices, events and texts. It entails, as Black elaborates, "exercise of power [that] could be manifested in the conceptualisations of problems... how are they manipulated, and how do they shift over time and space." This includes inquiry on whether power is binary or fragmented and, if fragmented, what interpretations are adopted and rhetorical devices used in attempts to persuade others. It also looks into the relationship between knowledge and power; exclusivity between the two would imply greater reliance on individuals and groups, inside or outside the government's apparatus, in possession of other more traditional sources of power, i.e. knowledge. Greater concentration of power within the formal decision-making circles would imply ideation in the background of the policy debate and only in its fragmented form appearing at the foreground. This relationship is aptly summed-up by Black when she writes "regulatory conversations may reveal that what 'on paper' looks to be a hierarchical system of command and control is in fact characterised by significant interdependencies, power dispersal, and fragmentation... or in contrast...in fact characterised by the display of considerable discursive power by one firm or individual: their interpretations of rules are adopted, or their conceptualisations of issues or problems, or criteria of success or failure. ${ }^{, 69}$

The last contention pertains to contestation of meaning, identities, knowledge and power in discourse analysis. This implies, as Black writes, "meaning is never completely fixed, because identities and positions may be contested in different discourses, because knowledge and power will be contested, change will occur as new meaning develop, different identities are constructed, and different systems of

${ }^{69}$ Ibid, $193-194$ 
knowledge and configuration of power come in to prominence." ${ }^{, 70}$ Contestation in discourse analysis operates more vividly at the foreground of the policy debate on the proposed ideational framework of public policy. While it may vary in its intensity between cognitive, normative and material levels, it is more central in shaping contest-interested ideas.

These contentions imply a dynamic understanding of institutions and of agents that are sentient with ideational abilities. By drawing on discourse analysis for understanding the mechanism through which ideas originate and affect policy outcomes, it would require as Black elaborates, "To look at whom conversations are between, where they occur within the regulatory process or regime, what they are about, and how they 'work' to co-ordinate action and constitute regulation. It would also look at the ways through which interpretations and conceptualisations are formed and how these understandings are shared and by whom, which of these are contested and between whom, and at the strategies used in developing or contesting those understandings, including rhetorical devices."71

Howarth argues that discourse theory and analysis is a problem-driven science wherein specific methods are developed in view of the problem at hand and the ontological assumptions one makes. ${ }^{72}$ Discourse analysis is not about the exclusion of other methods. ${ }^{73}$ The methodological approach proposed by Julia Black also brings insights from conversational analysis, Foucauldian analysis and critical discourse theory to understand the regulatory process. She writes that "merely to adopt the techniques of conversational

\footnotetext{
${ }^{70}$ Ibid, 194

${ }^{71}$ Ibid, 195-6

${ }^{72}$ Howarth, D., "The Method of Articulation," in Margo van den Brink and Tamara Metze (eds.) Words Matter in Policy and Planning (Utrecht, Labor Grafimedia, 2006): 23 - 42

${ }^{73}$ Brink, Margo van den and Metze, T., "Words matter in Policy and Planning," in Margo van den Brink and Tamara Metze (eds.) Words Matter in Policy and Planning (Utrecht, Labor Grafimedia, 2006): 13
} 
analysis, for example, will not tell us much about the operation of the regulatory process," given its narrow understanding of the context. She further argues that "because of the nature of regulation as an instrument of governmentality," attention to Foucauldian perspectives and to critical discourse analysis should also be drawn." 74 However policy discourse cannot be devoid of a political system. Atkinson et al write that in discourse theory derived from the work of Foucault "power and discourse cannot be separated as discourse is shaped by power and power shapes discourse." ${ }^{, 75}$ In a political system this would be akin to Dahl's twodimensional classification of polyarchy of contestation and inclusiveness. For countries in grey-zone and in the words of Dahl, this is the degree by which citizens [or the groups that represents citizens] have "unimpaired opportunities ...to formulate their preferences, signify their preferences to their fellow citizens and the government by individual and collective action and have their preferences weighed equally in the conduct of the government..." and inclusiveness is the variation "in the proportion of the population entitled to participate on a more or less equal plane in controlling and contesting the conduct of the government" ${ }^{\text {"76 }}$ In the 'policy-as-discourse' approach, this implies the argumentative turn in policy analysis and planning where language profoundly shapes our understanding of the world and public policy is made of language. ${ }^{77}$ Neyer and Schroeter have advanced Dahl's two-dimensional classification of polyarchy to deliberative approach in public policy. ${ }^{78} \mathrm{In}$ 'policy-asdiscourse' approach, and as per the understanding of Neyer and Schroeter, inclusiveness

\footnotetext{
${ }^{74}$ Black, J., 2002: 173

${ }^{75}$ Atkinson, R., Held, G., and Jaffares, S., "Theories of Discourse and Narrative," in Rob Atkinson, Terizakis Georgios, Karsten Zimmermann (eds.) Sustainability in European Environmental Policy: Challenges of Governance and Knowledge (New York: Routledge, 2011): Chapter 6

${ }^{76}$ Dahl, Robert A., Polyarchy: Participation and Opposition (New Heaven: Yale University Press, 1971): 2

${ }^{77}$ Buchstein, H. and Jörke, D., "The Argumentative Turn toward Deliberative Democracy: Habermas's Contribution and the Foucauldian Critique," in Frank Fischer, Herbert Gottweis (eds.) The Argumentative Turn Revisited: Public Policy as Communicative Practice (Durham: Duke University Press, 2012): 271

${ }^{78}$ Neyer, J. and Schroeter, M., "Deliberative Europe and the Rejected Constitution," in Erik Oddvar Eriksen, Christian Joerges and Florian Rödl (eds.) Law and Democracy in the Post-National Union (Oslo: Center for European Studies, 2006): $64-66$
} 
would then refers to the "degree to which those who are affected by a policy have a fair say in its formulation," and the contestation would imply the degree to which the affected parties have a chance to block the adoption of policies which they decide to oppose." ${ }^{, 79}$ For Neyer and Schroeter, both inclusiveness and contestation are crucial for any deliberative process in public policy. ${ }^{80}$ For this research, the theoretical approach of 'regulatory conversation' of Julia Black and the two-dimensional classification of polyarchy is triangulated with the proposed ideational framework of public policy and used as the overarching methodological choice.

The ideational framework of public policy proposed in the previous chapter allows categorisation of different types of ideas as per their influence on the policy process and its outcomes. In the perspective of regulatory conversations as explained above, the analysis of public policy process and its outcomes would focus on three interrelated facets that constitute institutions and form the basis for ideas, namely 'text,' 'agency' and the 'structural context.' Analysis of the text [what is said] will provide interpretation of ideas as in social and intersubjective production of meaning whereas agency [who said what to whom] will inform us of interactively acquired or constituted identities of different actors involved in the decisionmaking process. Inquiry into the structural context [where, when, how and why it was said] will explore processes by which meaning is assigned and disseminated and the ability of the actors in constructing agenda, conceptualising problems and rendering the uncertain certain. Structural context will also look into the processes and its dispersion in construction of meaning and identities and configuration of power. On the proposed ideational framework of public policy, analysis of text would help us determining the value dimension of decisionmaking and analysis of relationships between language and power and of language, thought

\footnotetext{
${ }^{79}$ ibid, p. 65

${ }^{80}$ ibid
} 
and knowledge within the structural context would enable us positioning public policy outcomes on the material and instrumental dimensions respectively. Analysis of contestation in structural context will inform us of the degree of politics of interests whereas study of actors' identities will help us in contrasting public policy outcomes between different dimensions of the ideational framework.

The five contentions presented by Julia Black to elaborate the relationship of social practices and discourse also draws on the degree to which a political process generates results in a contested and participatory manner. ${ }^{81}$ In a 'policy-as-discourse' approach, the communicative conditions for formation of opinion and political will function as an important channel for rationalization of policy decision. ${ }^{82}$ Dahl writes, of regimes moving towards a political system of polyarchy is when "they increase the opportunities for effective participation and contestation and hence the number of individuals, groups and interests whose preferences have to be considered in policy making." ${ }^{83}$ In the ideational framework of public policy, participation is the extent to which a policy agenda is shaped in the foreground of policy formulation. In the perspective of regulatory conversation, the research would then look into the degree the interpretation and pre-interpretive position of norms in policymaking process are the results of communicative interaction with those whose behaviour is sought to be changed. It would look into the dominant discourse and the extent to which identities of actors and organizations involved in the policy making process are at the foreground of policy formulation. It will also assess the openness of the discursive nature of policymaking in defining policy problem and creating knowledge. Similarly, the element of contestation in the ideational framework of public policy is the extent to which power is dispersed in

\footnotetext{
${ }^{81}$ Zilla, C., "Deliberative Democracy," in George Thomas Kurian (editor-in-chief) The Encyclopedia of Political Science (Washington, DC: QC Press, 2011): 385

82 ibid

${ }^{83}$ Dahl, Robert A., Polyarchy (New Heaven, Yale University Press, 1971): 14
} 
discursive practices and the meaning, identities, knowledge and power in policy formulation are results of competing interests. In summary, the contentions of preinterpretation/interpretation, identity and knowledge would signify the element of participation and the contentions of power and contestation would describe the dimension of contestation. See table 4.1 and based on the five contentions and the ideational framework of public policy see guidelines for in-depth interviews annexed at the end of this chapter.

\section{4: IDEATIONAL FRAMEWORK OF PUBLIC POLICY}

For empirical researchers, writes Peter John, "theory in social sciences is usually based on claims about the nature of human action and power relationship, and seeks to provide a coherent and consistent account of reality." ${ }^{84}$ At a broader level perhaps then a theory is essentially "a set of analytical principles designed to structure our observations and explanation of the world." ${ }^{, 85}$ However, due to the complexity of the policy process that spans over many disciplines and their subfields, there is absence of a commonly accepted, clearly articulated and empirically verified theory of public policy. ${ }^{86}$ The nature of explanation in the policy and planning sciences, writes Frank Fischer, "is scarcely straightforward" to serve as basis for guiding social action as it can take numerous forms where no one form is privileged over another. ${ }^{87}$ If there is a way out of this for theorists and researchers to this seemingly endless variety of processes to observe, argues John, it is in developing a framework with the ability to conceptualise the relationship between core causal processes. ${ }^{88}$ The account

\footnotetext{
${ }^{84}$ John, P., "Is there Life After Policy Streams, Advocacy Coalitions and Punctuations: Using Evolutionary Theory to Explain Policy Change," The Policy Studies Journal Vol. 31, No. 4 (2003): 482

${ }^{85}$ Cairney, P., 2012: 5

${ }^{86}$ Sabatier, Paul A., "Toward Better Theories of the Policy Process," Political Science and Politics, Vol. 24, No. 2 (1991): 153

${ }^{87}$ Fischer F., 2003: 21

${ }^{88}$ John, P., 2003: 487
} 
provided by the proposed ideational framework rests on discursive means and practices that are originated and constituted by 'text,' 'agency,' and the 'structural context, and result in the construction of ideas. As Schmidt writs that discourse is not just 'text' but also context and not only refers to structure but also to agency. ${ }^{89}$ These ideational constructs, in turn, become basis for policy decisions, central to how policymakers conceive and evaluate their options and how and what they decide. Institutions, in ideational understanding, are then collection of these interrelated ideational constructs that are themselves affected by its institutional environment for their subsequent design and development. With the basic claim that ideational institutionalism has the capacity to inform an endogenous account of complex institutional evolution, continuation, adaptation, and innovation, the ideational framework presented in the previous chapter is revisited for postulating key claims for this research (see table 2).

Claim I: Actors in policy process are oriented subjectively towards their environment as their desires, preferences, and motivations are not a contextually given fact but are irredeemably ideational.

The fundamental claim of ideational institutionalism and also its point of departure from the three established schools of new institutionalism is that actors desires, preferences and motivations are not predetermined through rationalist preferences, historical paths or cultural norms but are irredeemably ideational reflecting subjective orientation towards the context in which they will have to be realised. ${ }^{90}$ This is also the focus of the 'policy-as-discourse'

\footnotetext{
${ }^{89}$ Schmidt, Vivien A., 2008: 305

${ }^{90}$ Hay, C., 2006: 63
} 
theorists whose starting place for policy analysis is not the 'problem' but problematisation. ${ }^{91}$ In Goodwin's words, in policy-as-discourse approach, policies are not framed in response to existing conditions and problems, "but more as a discourse in which both problems and solutions are created". ${ }^{92}$ This is also a key objective of discourse theory to elucidate carefully problematised objects of study by seeking their description, understanding and interpretation. ${ }^{93}$ For this research, it would imply that types of ideas, as described in the proposed ideational framework, not only affect the course of the policy process but also are the basis of proposed public policy solutions and eventual outcomes.

Claim II: Actors in policy process are strategic, seeking to realise policy goals while relying upon their subjective perceptions of the context and favouring certain strategies over others through applying multiple levels of criteria, i.e. material, normative and cognitive.

Institutions, in ideational institutionalism, are internal to sentient agents that serve both as structures that constrain action as well as constructs created and changed by those actors. ${ }^{94}$ These sentient agents are strategic who favours certain strategies over others while seeking to realise their policy goals. Actors' orientation towards their environment, therefore, is based on their perception of the context in which they seek to realise their policy goals. ${ }^{95}$ Change in ideational institutionalism, as argued by Hay and Wincott, "is seen as the consequence

\footnotetext{
${ }^{91}$ Kritzman, L. D., (ed.) M. Foucault: Politics, Philosophy, Culture: Interviews and Other Writings 1977-1984 (New York: Routledge, 1988): 257

${ }^{92}$ Goodwin, N., "Governmentality in the Queensland Department of Education: Policies and the Management of Schools," Discourse, Vol. 17, No. 1 (1996): 67

${ }^{93}$ Howarth, D., "The Method of Articulation," in Margo van den Brink and Tamara Metze (eds.) Words Matter in Policy and Planning (Utrecht, Labor Grafimedia, 2006): 25

${ }^{94}$ Schmidt, Vivien A., "Taking Ideas and Discourse Seriously: Explaining Change through Discursive Institutionalism as the Fourth 'New Institutionalism'," European Political Science Review, Vol. 2, No. 1 (2010): 4

${ }^{95}$ Hay, C., 2006: 63
} 
(whether intended or unintended) of strategic action (whether intuitive or instrumental), filtered through perceptions (however informed or misinformed) of an institutional context that favours certain strategies, actors perceptions over others." ${ }^{.96}$ These perceptions serve as 'cognitive filters' through which actors conceptualise and assess potential merits and demerits of contending course of policy actions as to what is feasible, legitimise, possible and desirable. ${ }^{97}$ Béland argues that such 'cognitive filters' concern "both self-perceptions and the framing processes that actors use to convince others that it is in their interest to mobilise with them in order to reach shared goals and have an impact on outcomes." 98 This is one of the central contentions of ideational institutionalism that "ideas shape how we understand political problems, give definition to our goals and strategies, and are the currency we use to communicate about politics." 99 Béland and Cox argue that ideas "embrace thoughts, emotions, desires, as well as interests, all in delicate and fluid balance with one another. ${ }^{100}$ The basic claim in this research is that it is not just a rational pursuit of actors for maximising their self-interest, or dictation of their actions through symbolic systems, cognitive scripts or moral templates, or even their dependency on enduring legacies but essentially an interplay of myriad of ideas that have cognitive, normative and material characteristics. This distinction of ideas, their interaction with one another and the stable system they form together to serve as criteria for evaluation for different course of policy actions is aptly summed up by Corina Barbaros when she distinguishes between three types of ideas as those that have "primarily, a cognitive character being descriptions of social political, economic situations and tools for understanding how things work... a normative nature which consists in ideals, values and norms that define what is good or bad...[and] a third category of ideas

\footnotetext{
${ }^{96}$ Hay, C., and Wincott, D., "Structure, Agency and Historical Institutionalism," Political Studies, Vol. 46 (1998): 955

${ }^{97}$ Ibid, 956

${ }^{98}$ Béland, D., 2010: 148

${ }^{99}$ Béland, D., and Cox, Robert H., "Ideas and Politics," in Daniel Béland and Robert H. Cox (eds.) Ideas and Politics in Social Science Research (Oxford: Oxford University Press, 2011): 3

${ }^{100}$ Ibid, 15
} 
that regards the desires that form people's preferences. ${ }^{101}$ She further asserts that "it is important to distinguish between these three types of ideas, but they are different just in analytical sense, in discursive and perceptual reality they not only interact but form stable systems."102

\section{Claim III: Actors use ideas of various kinds to interpret and construct their situation and in turn derive their interest and preferences from such constructions; their policy preferences and decisions, however, are in reflection of and favours certain set of ideational construct or dominant ideas in relation to others.}

Discourse analysis is linked to power and dominance. Its purpose is not only to identify discursive means and practices through which ideas are constructed and communicated but also to assess their varying influence on meaning creation and which of these solidifies into an institution. ${ }^{103}$ Foucault imagines society as a network of interlocking dominant discourses, all having to do with the production of selves. ${ }^{104}$ A dominant discourse, writes Brookfield, “comprises a particular language and a distinctive worldview in which some thing are regarded as inherently more important or true than others." ${ }^{105}$ Similarly, in ideational understanding and as Sidney argues, "policy making takes place at a particular moment in

\footnotetext{
${ }^{101}$ Barbaros, C., "Do Issues Decide? Thematic and Partisan Ideational Strategies in Electoral Debates," Argumentum Journal, Vol. 10, No. 1 (2012): 114

102 Ibid

${ }^{103}$ Hajer, Maarten A., 2006: 70

${ }^{104}$ Foote, Catherine E. and Frank, Arthur W., "Foucault and Therapy: The Disciplining of Grief," in Adrienne S. Chambon, Allen Irving and Laura Epstein (eds.) Reading Foucault for Social Work (New York: Columbia University Press, 1983): 172

${ }^{105}$ Brookfield, S. The Power of Critical Theory for Adult Learning and Teaching (Berkshire: Open University Press: 2005): 138
} 
time, marked by particular dominant ideas related to the policy issue." ${ }^{, 106}$ According to Doern and Phidd, dominant ideas provide shape to particular policy issues and also used in public policy debates and underlie public policies. ${ }^{107}$ Stewart and Ayres assert that policy agenda, that is what government choose to act upon, shape policy-making activities and reflect dominant ideas. ${ }^{108}$ The research claims that while actors use ideas of various kinds to interpret and construct their situation shaping their interest, preferences and identities using multiple frameworks, i.e. cognitive, normative and material, but their decisions are reflective more of a dominant set of ideas, either in the background or foreground of the policy debate.

Claim IV: Increase participation of those whose behaviours is to be influenced, formulation of policy proposals and their solutions by actors will be the results of ideas at the foreground of policy debate and their decision more a reflection of competing interests with increase in the level of contestation among policy actors.

Schmidt writes that sentient agents in a policy setting consciously change "their institutions for better or for worse - through deliberation, contestation, as well as consensus-building around ideas." ${ }^{\prime 109}$ In a pluralistic society, this represents open membership and participation in interest groups and formal or informal institutionalised channels of interest group intermediation in policymaking. Conversely it implies, in the words of Grugel, a thin democracy where patterns of participation are low and the state has few obligations to listen

\footnotetext{
${ }^{106}$ Sidney, Mara S., "Policy Formulation: Design and Tools," in Frank Fischer and Gerald J. Miller (eds.) Handbook of Public Policy Analysis: Theory, Politics, and Methods (Boca Raton: CRC Press, 2007): 84

${ }^{107}$ Doern, G. B., and Phidd, R. W., Canadian Public Policy: Ideas, Structure, Process, $2 \mathrm{~d}$ ed. (Toronto: Nelson Canada, 1992):

${ }^{108}$ Stewart, J., and Ayres, R., "The Public Policy Process," in Chris Aulich, John Halligan, Sandra Nutley (eds.) Australian Handbook of Public Sector Management (New South Wales: Allen \& Unwin, 2001): 21

${ }^{109}$ Schmidt, Vivien A., 2010: 9
} 
to society. ${ }^{110}$ This research postulates that importance to expertise and the technical framing of political argumentation will lead to marginalization of citizen participation in policymaking. ${ }^{111}$ Similarly, with authority vested in experts, "being above the sphere of politics and competition," policy formulation and their solution will be result of what those experts define as "practicable course of action." 112 In the same vein, increase contestation in policy formulation leads the policymaking process and outcomes to reflect demands and struggles of competing political parties and interest groups. ${ }^{113}$ The research further postulates that as the public policy spectrum becomes more inclusive the ideas in the foreground of policy formulation become dominant and as the contestation increases the dynamics move towards material dimension. This is in lines with Dahl's conceptualization of regime type in terms of two intersecting continue that, as Remmer argues, "takes us away from the enormous confusion that has resulted from the definition of regime types in terms of syndromes of interrelated traits."114

Based on the policy-as-discourse approach, the next chapter provides the overall research methodology. However, it is imperative that a few key methodological concerns when developing a public policy theory are first discussed.

\section{5: DEVELOPING A PUBLIC POLICY THEORY - SOME METHODOLOGICAL CONSIDERATIONS}

\footnotetext{
${ }^{110}$ Grugel, J., Democratization: a Critical Introduction (New York: Palgrave, 2002): 115

111 Fischer F., 2003: 36

112 ibid, 49

113 ibid, 26

${ }^{114}$ Remmer, Karen L., "Exclusionary Democracy," Studies in Comparative International Development, Vol. 20, No. 4 (1985): 70
} 
Public policy outcomes are often the result of complex interplay of various institutional variables, at times even in the most internalised of political systems. As a result, existing theories of public policy present only some of the facets, but not all, of this process and its outcomes. Greenberg et al elucidates on this point and write, "Although the theories [of public policy] seemed perfectly applicable to the few cases used by their authors to illustrate them originally, the propositions did not fit so neatly when applied to a number of examples not expressly chosen for explanation and illustration. ${ }^{115}$ They contend that analysis of public policy is complex on at least four counts. First, public policy process is stretched over a long period of time that leads to difficulty in explaining the process. The long process creates large number of decision points that result in losing focus on the eventual outcomes. The predictive power of theories is also undermined, as values set at the beginning of the process are likely to change with the unfolding of the process itself. Second, a public policy outcome might have multiple facets making it difficult to be placed in a single category, as demanded by the categorisation schemes in public policy theory, i.e. the types of policies proposed by Theodore Lowi. ${ }^{116}$ The process of public policymaking is further complicated by the presence of a large number of participants and, therefore, analysis depends upon the participants consulted or described. Lastly, simple additive models cannot describe the process of public policy, as the impact of one variable depends on large part upon the value and interaction of another. ${ }^{117}$ For application of the proposed ideational framework of public policy, the problems of temporality, predictability, multiplicity of participants and interaction in the determination of public policy outcomes are addressed in this section.

\footnotetext{
${ }^{115}$ Greenberg, George D., Miller, Jeffrey A., Mohr, Lawrence B. and Vladeck, Bruce C., "Developing Public Policy Theory: Perspectives from Empirical Research," American Political Science Association, Vol. 71, No. 4 (1977): 1532

${ }^{116}$ See: Lowi, Theodore J., "Four Systems of Policy, Politics and Choice," Public Administration Review, Vol. 32, No. 4 (1972): 298 - 310

${ }^{117}$ Greenberg, George D., Miller, Jeffrey A., Mohr, Lawrence B. and Vladeck, Bruce C., 1977: 1533
} 


\subsection{1: TEMPORALITY}

In their analysis, Greenberg et al argue that it is essential that "both when policy hypotheses are proposed and when they are tested, to have in mind some reasonable criteria for demarcating the process temporally." overcome by agreeing on the beginning point in the policy process and the point at which it might be said that policy was indeed made. ${ }^{119}$ In another work, Greenberg et al introduce the concept of points of "last significant controversy" and "first significant controversy" to identify beginning and ending points in the policy process. ${ }^{120}$ The point of "last significant controversy" in the policy process is a stage after which substantial changes in the outcome are no longer realistic alternatives, at least for a time being, such as voting on a proposed legislative bill. The point of "first significant controversy," however, is more elusive and its identification is relative on actors' perception of the instance that triggered the policy process at the first place. This is what Carol Baachi also recommends in her approach to analysing policy process of 'working backwards' from concrete policy documents or proposals. ${ }^{121}$ In this research also the Hajer ten-step framework to discourse analysis and snowball sampling from the main protagonists - the legislator - of selected cases of public policy outcomes is from the time of the passing of the bill and its enactment into an act and working backwards to the point of 'first significant controversy' when need for legislation is publically expressed for the first time, either in form of a legislative proposal, press statement or similar instrument by a policymaker.

\footnotetext{
${ }^{118}$ Ibid, 1537

${ }^{119}$ Ibid, 1542

${ }^{120}$ Greenberg, George D. et al. Case Study Aggregation and Policy Theory (University of Michigan, Institute of Public Policy Studies, 1973)

${ }^{121}$ Bacchi, C., Analysing Policy: What's the Problem Represented to be? (Frenchs Forest, NSW: Pearson Education, 2009)
} 


\subsection{2: PREDICTABILITY}

Greenberg et al concurs that values of the predictors determined at some beginning point of the policy process for the formulation of a predictive theory of public policy change with the unfolding of the process itself. As a result, they explain, "Many presumably predictive theories are thereby weakened substantially, and become, in final analysis post hoc explanations." 122 Their recommendation of causal variables is that they should be "observable and measureable at a point in time before the effect and should not be subject to significant change beyond that point of evaluation." "23 Another complication arises from the problems of temporality as they write, "The duration, scope, or complexity of a given policy struggle are rarely strictly determined at the outset; not only are outcomes often unpredictable, but so too is the process." ${ }^{\prime 24}$ Due to these very concerns, the inductive and descriptive nature of this research, based on qualitative methodology, is striving for theoretical rather than empirical generalisation of its working hypotheses.

\subsection{3: MULTIPLICITY OF PARTICIPANTS}

Greenberg et al, in their analysis, highlight the issue of large number and different types of participants involve in the policy process and affecting the final outcome. ${ }^{125}$ This problem is further exacerbated due to different perception of participants of the status of affairs and operationalisation of their objective characteristics and behaviours. ${ }^{126}$ It is essential for

${ }^{122}$ Greenberg, George D., Miller, Jeffrey A., Mohr, Lawrence B. and Vladeck, Bruce C., 1977: 1533

${ }^{123}$ Ibid, 1542

${ }^{124}$ Ibid, 1537

${ }^{125}$ Ibid, 1533

${ }^{126}$ Ibid, 1543 
ideational analysis that actors involved in the policy process and affecting its outcome through discursive means and practices are identified.

The framework proposed by Mantzana et al for identification of different actors involved in the adoption of information system can be applied in general to the policy process. ${ }^{127}$ Mantzana et al divide actors into individuals and organisations and define them as those who accept, provide, support or control changes in health care sector, to which they call a static approach. Their research looks into adoption of change, e.g. use of information systems, rather than the process through which adoption or rejection of a proposed change occurs. Therefore, there could be a crosscutting category of 'detractor' added to this framework that may fall into any of the other four categories of actors. Mantzana et al move further from static to a dynamic approach and provide a set of guidelines for application of their framework in the identification of actors. They divide guidelines into principles and dimensions. Principles calls for actors to be seen as dependent on the specific context and time, who cannot be viewed in isolation, whose position may change over time and whose options may differ from their wishes. While dimensions calls for looking into actors in perspective to the change, their orientation as being internal or external, their relationship in the overall system, and their level of aggregation and depth of impact.

Accordingly, Figure 4.1 provides mapping of broad categories of actors in an institutional environment of a public policy process. The institutional environment has mainly five actors. Firstly, the policymakers [providers] with whom the formal authority rests. The second actor is the wider administrative apparatus [controller], i.e. bureaucracy, that are tasked with the implementation of the eventual policy outcome. The third category consists of various

${ }^{127}$ Mantzana, V. et al., "Identifying Healthcare Actors Involved in the Adoption of Information System," European Journal of Information Systems, Vol. 16 (2007): 91 - 102 
interest groups and lobbyists [supporters], inside or outside the country, who affect policymakers/policymaking process in order to win favourable public policy outcomes. The fourth category is of end-users [acceptors] who interact with all three abovementioned actors and are the ultimate users of the public policy. The final and crosscutting category is of 'detractors' constituting of actors who oppose to the proposed policy solution (see Figure 4.1). This framework is applied to this research in identification of actors in different categories through snowball sampling starting with main protagonists.

Figure 4.1:

Actors Affecting Public Policy Process and Outcome in Ideational Understanding

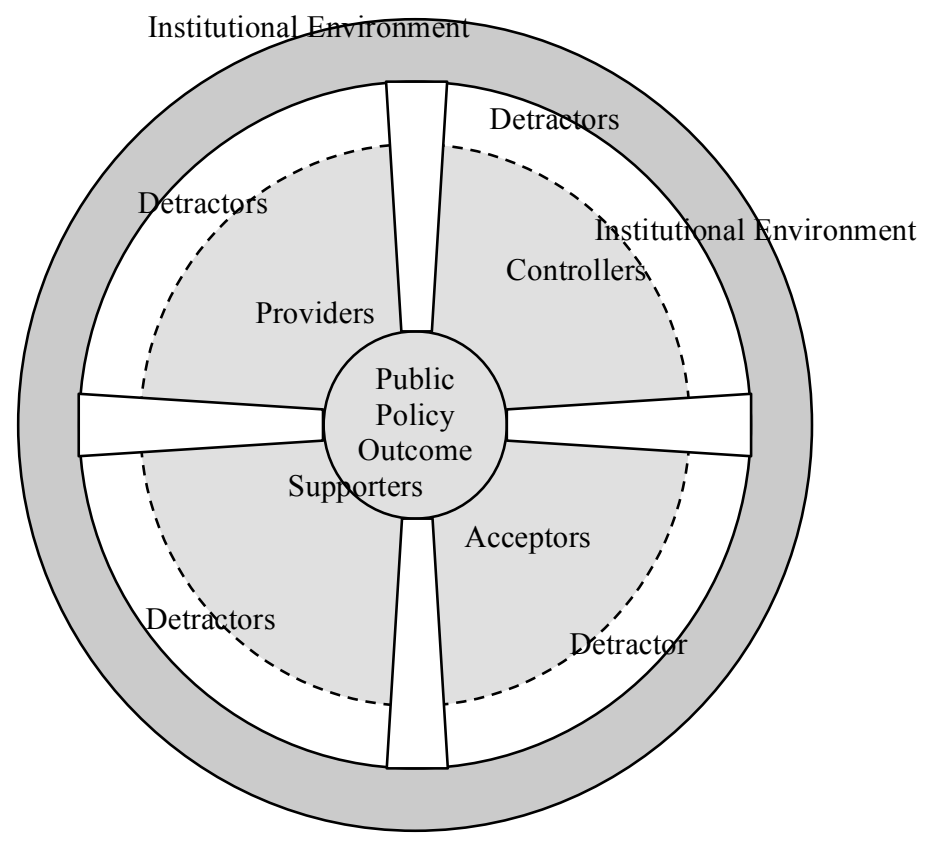

\subsection{4: INTERACTION}

Greenberg et al define 'interaction' as 'existence or strength of an effect being contingent upon some other condition or the value of some additional variable." ${ }^{128}$ Their basic contention is that theories of public policies are rendered inadequate if it fails to specify

${ }^{128}$ Greenberg, George D., Miller, Jeffrey A., Mohr, Lawrence B. and Vladeck, Bruce C., 1977: 1540 
major conditions defining its applicability that includes interaction among independent variables in determining a policy outcome. Due to the logic of discourse, the 'interaction' within and among the broad sets of variables forms the basis of the proposed ideational framework. It effectively lays out three dimensions on which policy proposals are evaluated by actors involved and a continuum of policy debate to determine the nature of politics that shape eventual policy outcomes.

In conclusion Greenberg et al write, "Because of the complexities of public policy as an object of study, we may never be able to obtain hard knowledge of the policy process of the type available in the advanced physical sciences. Yet improving our understanding of policy phenomena is clearly possible, if only through advancing the conceptual sophistication of theoretical formulations." 129 The aim of this chapter was the same to advance the conceptual sophistication of ideas and its impact on public policy outcomes and to layout a detailed research methodology for theory formulation by addressing limitations and weaknesses of the existing theories and models of public studies.

\section{6: CONCLUDING WORDS}

Smith and Katikireddi arrive at a conclusion while developing a glossary of theories for understanding policymaking that "no single [public policy] theory offers a comprehensive description of the policy process and all are limited by their origins in high-income, democratic settings." This is an astounding statement for a discipline that grew out in 1940s and early 1950s, credited to the work of Harold D. Lasswell, but can be traced almost as far

${ }^{129}$ Ibid, 1543 
back as the beginning of human civilisation. ${ }^{130}$ While there have been theoretical advancements, policy theory has neglected ideas due to its general theoretical shortcomings. ${ }^{131}$ The methodological approach outlined in this chapter aims at contributing towards recent return in policy studies of an interest in ideas and discourse with a focus on overcoming theoretical shortcomings.

\footnotetext{
${ }^{130}$ Miyakawa, T. (ed.), The Science of Public Policy: Essential Readings in Policy Sciences, pt. 1 (London: Routledge, 1999): 9

${ }^{131}$ Fischer, F., 2003: 27
} 


\begin{tabular}{|c|c|c|c|}
\hline \multicolumn{4}{|c|}{$\begin{array}{l}\text { Table 4.1: } \\
\text { Applying the Concept of 'Regulatory Conversations' to the Ideational Framework of Public Policy }\end{array}$} \\
\hline Contentions & Goal & $\begin{array}{l}\text { Dimensions of } \\
\text { inquiry }\end{array}$ & Sources of information \\
\hline $\begin{array}{l}\text { Pre- } \\
\text { interpretation } \\
\text { / } \\
\text { interpretation }\end{array}$ & $\begin{array}{l}\text { To identify the problem } \\
\text { how it is represented in } \\
\text { policy and to ascertain } \\
\text { the conceptual premise } \\
\text { or logic that underpin } \\
\text { the same in its } \\
\text { representation. }\end{array}$ & $\begin{array}{l}\text { Text; normative } \\
\text { dimensions } \\
\text { whether used as } \\
\text { assumptions or } \\
\text { prescriptions to } \\
\text { forge public } \\
\text { policy outcomes }\end{array}$ & $\begin{array}{l}\text { Analysis of text; written, verbal and } \\
\text { nonverbal communication before } \\
\text { and during the course of the policy } \\
\text { process; includes organisational } \\
\text { files, records, legislation, judicial } \\
\text { decisions, bills, speeches, interview } \\
\text { transcripts, media statements or } \\
\text { articles, press release, research } \\
\text { reports, contracts and nonverbal } \\
\text { sources such as events, incidents and } \\
\text { ceremonies. }\end{array}$ \\
\hline Identity & $\begin{array}{l}\text { To assess how different } \\
\text { actors view individuals } \\
\text { and organisations } \\
\text { involved and how their } \\
\text { identities are shaped in } \\
\text { the public policy } \\
\text { process. }\end{array}$ & $\begin{array}{l}\text { Agency; actors } \\
\text { mapping and } \\
\text { identification of } \\
\text { dominant } \\
\text { discourse }\end{array}$ & $\begin{array}{l}\text { Actors' analysis through } \\
\text { observation, interviews of actors } \\
\text { involved in the process and review } \\
\text { of existing interpretations of their } \\
\text { characteristics, capabilities, } \\
\text { discursive and discourse related } \\
\text { practices targeted at maintaining or } \\
\text { changing dominant discourses. }\end{array}$ \\
\hline Knowledge & $\begin{array}{l}\text { To highlight the } \\
\text { instrumental dimensions } \\
\text { and the extent to which } \\
\text { it is used in framing } \\
\text { public policy solutions. }\end{array}$ & $\begin{array}{l}\text { Structural context; } \\
\text { instrumental } \\
\text { dimensions, in the } \\
\text { background and } \\
\text { foreground of } \\
\text { policy formulation }\end{array}$ & $\begin{array}{l}\text { Analysis of the discursive setting } \\
\text { that combines the 'text' dimensions, } \\
\text { e.g. distinctive discursive forms, } \\
\text { together with 'discursive practice' } \\
\text { that looks into process of text } \\
\text { production and interpretation and }\end{array}$ \\
\hline Power & $\begin{array}{l}\text { To ascertain the extent } \\
\text { to which power is } \\
\text { exercised, composition } \\
\text { of power, i.e. binary or } \\
\text { fragmented, in forging } \\
\text { and enacting public } \\
\text { policy solution. }\end{array}$ & $\begin{array}{l}\text { Structural context; } \\
\text { material } \\
\text { dimension in the } \\
\text { background of } \\
\text { policy formulation }\end{array}$ & $\begin{array}{l}\text { 'social practice' referring to the } \\
\text { institutional and organisational } \\
\text { circumstances. This would include } \\
\text { examination of social and political } \\
\text { context; formal power and authority } \\
\text { structure; social and institutional } \\
\text { logics and social relations that bind }\end{array}$ \\
\hline
\end{tabular}




\begin{tabular}{|l|l|l|l|}
\hline \multicolumn{3}{|l|}{$\begin{array}{l}\text { Table 4.1: } \\
\text { Applying the Concept of 'Regulatory Conversations' to the Ideational Framework of Public Policy }\end{array}$} \\
\hline Contentions & Goal & $\begin{array}{l}\text { Dimensions of } \\
\text { inquiry }\end{array}$ & Sources of information \\
\hline Contestation & $\begin{array}{l}\text { To explore how } \\
\text { identities are shaped } \\
\text { and positions jostled, } \\
\text { between the actors } \\
\text { involved, as well as } \\
\text { contestation of } \\
\text { knowledge and power } \\
\text { in influencing public } \\
\text { policy. }\end{array}$ & $\begin{array}{l}\text { Structural context; } \\
\text { material } \\
\text { dimension in the } \\
\text { foreground of the } \\
\text { policy formulation }\end{array}$ & $\begin{array}{l}\text { interlocutors together; resources } \\
\text { applied in discursive practices, i.e. } \\
\text { framework of argumentation, } \\
\text { narrative approaches; modes of } \\
\text { subjugation in communicative } \\
\text { exchange. Sources of information } \\
\text { are those mentioned for the analysis } \\
\text { of 'text' and 'actors' but primarily } \\
\text { through media reporting, minutes of } \\
\text { meetings, statements, as well as } \\
\text { interviews of actors involved in the } \\
\text { policy process. }\end{array}$ \\
\hline
\end{tabular}

\footnotetext{
${ }^{132}$ The structural dimension of this triangulation between the Ideational Framework of Public Policy and Regulatory Conversation is derived from the perspective of Critical Discourse Theory, in particular the work of Norman Fairclough, see: Fairclough, N. Discourse and Social Change (Cambridge, Polity Press: 1992)
} 


\begin{tabular}{|c|c|c|c|}
\hline & \multicolumn{3}{|c|}{$\begin{array}{l}\text { Table 4.2: } \\
\text { Ideational Framework of Public Policy }\end{array}$} \\
\hline Political System & \multicolumn{3}{|c|}{ 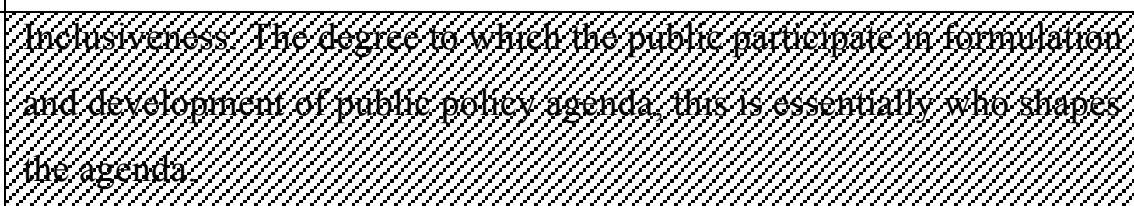 } \\
\hline & & $\begin{array}{l}\text { Types of Ideas in the } \\
\text { foreground of the policy } \\
\text { formulation }\end{array}$ & $\begin{array}{l}\text { Types of Ideas in the } \\
\text { background of the policy } \\
\text { formulation }\end{array}$ \\
\hline & $\begin{array}{l}\text { Criteria for } \\
\text { Evaluation }\end{array}$ & \multicolumn{2}{|c|}{ Public Policy Spectrum } \\
\hline & $\begin{array}{l}\text { Cognitive } \\
\text { level }\end{array}$ & $\begin{array}{l}\text { Programmatic Ideas: } \\
\text { Ideas as elite policy } \\
\text { prescriptions that help } \\
\text { policymakers to chart a clear } \\
\text { and specific course of policy } \\
\text { action. }\end{array}$ & $\begin{array}{l}\text { Paradigmatic ideas: } \\
\text { Ideas as elite } \\
\text { assumptions that } \\
\text { constrain the cognitive } \\
\text { range of useful solutions } \\
\text { available to policy } \\
\text { makers. }\end{array}$ \\
\hline & $\begin{array}{l}\text { Normative } \\
\text { level }\end{array}$ & $\begin{array}{l}\text { Public expectations: } \\
\text { Ideas as popular public } \\
\text { notions of ideal public } \\
\text { policy solutions that specify } \\
\text { policy actions for policy } \\
\text { makers or on the basis of } \\
\text { which they legitimise } \\
\text { proposed policy action. }\end{array}$ & $\begin{array}{l}\text { Public sentiments: } \\
\text { Ideas as assumptions of } \\
\text { public sentiments that } \\
\text { constrain the normative } \\
\text { range of legitimate } \\
\text { solutions available to } \\
\text { policy makers. }\end{array}$ \\
\hline & $\begin{array}{l}\text { Material } \\
\text { level }\end{array}$ & $\begin{array}{l}\text { Contest-interested ideas: } \\
\text { Ideas as outcomes of politics } \\
\text { of interests between } \\
\text { contending interest groups } \\
\text { that forms direction for } \\
\text { policy makers for specific } \\
\text { policy issues. }\end{array}$ & $\begin{array}{l}\text { Self-interested ideas: } \\
\text { Ideas as subjective } \\
\text { interpretation of self- } \\
\text { interest by which policy } \\
\text { makers evaluates the } \\
\text { relative merits of } \\
\text { contending potential } \\
\text { course of actions. }\end{array}$ \\
\hline
\end{tabular}

${ }^{133}$ Campbell, John L., 1998: 385 



\section{PUBLIC POLICY MAKING IN PAKISTAN}

\section{1: INTRODUCTION}

$\mathbf{P}$ ublic Policy is rooted in law, write Cochran et al, and "in the authority and coercion associated with law."1 As elaborated in the introductory chapter of this research, one of the defining features of the term public policy is a purposeful action taken by government. ${ }^{2}$ The understanding of Robert Salisbury of the terms is the same who sees public policy as consisting "in authoritative or sanctioned decisions by governmental actors." ${ }^{3}$ In his conception of public policy, Salisbury refers "to the 'substance' of what government does and ...distinguished from the processes by which decisions are made." Salisbury sees public policies as "the outcomes or outputs of governmental processes. " David Easton, however, distinguishes between outputs and outcomes of the political system produced by the authorities. ${ }^{6}$ He sees outcomes as the second order effects of public policy and outputs being the decisions and actions it contains. ${ }^{7}$ For Easton, 'authorities' in the political system in the modern age are the executives, legislators, judges,

\footnotetext{
${ }^{1}$ Cochran, C., Meyer, Lawrence C., Carr, T.R. and Cayer, N.J., American Public Policy: An Introduction (Boston: Wadsworth Cengage Learning, 2009): 2

${ }^{2}$ Volkomer, W., American Government, 11th ed. (Upper Saddle River, NJ: Prentice Hall, 2011): 330

${ }^{3}$ Salisbury, Robert H., "The Analysis of Public Policy: A Search for Theories and Roles," in Austin Ranney (ed.) Political Science and Public Policy (Chicago: Markham Publishing Co., 1968): 152

${ }^{4}$ Ibid

${ }^{5}$ Ibid

${ }^{6}$ Easton, D., Systems Analysis of Political Life (New York: John Wiley \& Sons, Inc., 1965): 349

${ }^{7}$ Ibid, $351-352$
} 
administrators, councillors and the like. ${ }^{8}$ These decision and actions taken by government authorities that form a public policy are in the shape of statutes, executive orders, administrative rules and judicial rulings. ${ }^{9}$ The main purpose of this chapter, therefore, is to study the constituting fundamentals of the Government of Pakistan and those with the formal authority of making public policies. ${ }^{10}$

The next section provides synopsis of basic constituting elements of the Federation of Pakistan. The federating units and the three main branches of the government of Pakistan, as prescribed in the 1973 Constitution of Pakistan and other relevant laws, are discussed in Section III and Section IV respectively. The formal process of public policy making in Pakistan is discussed in Section IV. Section V provides brief historical account of the Thirteenth National Assembly and its distinctiveness in the political history of Pakistan as well as its resume in respect to public policy making. The last section of the chapter provides some concluding thoughts.

\section{2: THE FEDERATION OF PAKISTAN}

Pakistan is a federation of four provinces, namely Balochistan, Khyber Pakhtunkhwa, Sindh and Punjab, the Federally Administered Tribal Areas and the Capital Territory of Islamabad. The Federally Administered Tribal Areas (FATA) and the Capital Territory of Islamabad (ICT) comes under the jurisdiction of the Federal Government. Pakistan also exercises de facto jurisdiction over two autonomous regions of Azad Jammu and Kashmir (AJK) and

\footnotetext{
${ }^{8}$ Ibid, 212

${ }^{9}$ Anderson, James E., Public Policymaking: An Introduction, 7th ed. (Boston: Wadsworth Cengage Learning, 2011): 8

${ }^{10}$ The Pakistan Provisional Constitution Order, 1947 and Adaptation of Existing Pakistan Laws Order 1947 defined Pakistani Law "shall mean any Act, Ordinances, Regulations, Rules and Orders, ByeLaws..."
} 
Gilgit-Baltistan (GB). Under the Gilgit-Baltistan Empowerment and Self-Governance Ordinance of 2009, the region is assigned a province-like status with full internal autonomy and establishes the office of the Chief Minister as leader of the Legislative Council and head of government. To establish the regional administrative control, the ordinance makes provision for appointed of a Governor by the Federal Government as the representative of the State as in other provinces of Pakistan.

The region of GB, however, does not have representation in the federal legislation, as is the case with AJK. ${ }^{11}$ AJK, on the other hand, has the self-governing status but has its own elected president, prime minister, legislature, high court, emblem and official flag, unlike GB. The highest linking forum between Pakistan and AJK is called "Azad Jammu and Kashmir Council," which is a constitutional body established under Section 21 of the Azad Jammu and Kashmir Interim Constitution Act of 1974. The Council is an 11-member body with executive, legislative and judicial sphere with six members from the Government of AJK, including President and Prime Minister of AJK, and five members from the Government of Pakistan. The Prime Minister of Pakistan serves as the Chairman of the Council.

The Constitution of Pakistan, enacted in 1973, provides for a parliamentary form of government with a President as the Head of State and Prime Minister as the Head of Government. The parliamentary democratic system of Pakistan gives the executive authority and political leadership to the Prime Minister who also presides over the country's cabinet. The Federation, as defined by the Constitution of Pakistan, consists of three governments at the federal, provincial and local levels. The Article 90 of Chapter 3 of the Constitution of

\footnotetext{
${ }^{11}$ Musarrat, R., Ali, G. and Azhar, Muhammad S., "Federalism in Pakistan, Current Developments," International Journal of Academic Research in Business and Social Sciences, Vol. 2, No. 4 (2012): $456-7$
} 
Pakistan stipulates "the executive authority of the Federation shall be exercised in the name of the President by the Federal Government, consisting of the Prime Minister and the Federal Ministers, which shall act through the Prime Minister, who shall be the chief executive of the Federation." Article 129 of the same chapter titled "The Provincial Government" states that the "executive authority of the Province shall be exercised in the name of the Governor by the Provincial Government, consisting of the Chief Minister and Provincial Ministers, which shall act through the Chief Minister." The last Article (140A) of Chapter 3 of the Constitution of Pakistan is titled "Local Government" and lays down that "each Province shall, by law, establish a local government system and devolve political, administrative and financial responsibility and authority to the elected representatives of the local governments." The administrative units of Pakistan are based on a three-tier system of federal, provincial and local governments discussed in more detail in the following section.

\section{3: THE STATE OF PAKISTAN AND ITS FEDERATING UNITS}

The First Constituent Assembly of Pakistan had adopted the Government of India Act 1935 with certain modifications as an Interim Constitution of Pakistan. The Federation, as defined by the Interim Constitution, consisted of four provinces, namely East Bengal, West Punjab, Sind and North- West Frontier Province (now Khyber Pakhtunkhwa), Baluchistan (did not have the status of the province as yet); any other areas that might with the consent of the Federation be included therein; Karachi as the capital of federation and such Indian states as might accede to the Federation of Pakistan. ${ }^{12}$

\footnotetext{
${ }^{12}$ Kamran, T., "Early Phase of Electoral Politics in Pakistan: 1950s," South Asian Studies, Vol. 24, No. 4 (2009): 279; Under the Government of India Act, 1935, provinces of the time were ruled by their Governors and there were other provinces called "Chief Commissioners' Provinces" which were directly ruled by the Governor General, who was the head of the Federation and nominated by the Queen. After independence, the province of Balochistan continued to be the Chief Commissioner's
} 
The partition plan under the Indian Independence Act of 1947, passed by the House of Commons, provided that contiguous Muslim majority districts in Punjab and Bengal would be subsumed into the state of Pakistan, provided the legislature of the two agreed that the provinces should be partitioned, which they did. ${ }^{13}$ The Sindh legislature and Council of Tribal Leaders (Jirga) in Balochistan agreed to join Pakistan whereas plebiscites in the Sylhet district of Assam (amalgamated into Bengal province) and in the North-West Frontier Province also resulted in favour of choosing Pakistan. The 562 princely states, however, were given the option to accede either to Pakistan or India based on the factors of geographic contiguity, religious identity of the majority population and the right of the accession of the ruler. ${ }^{14}$ With the exception of three states, namely States of Hyderabad, Jammu and Kashmir and Junagadh, all 562 states quickly acceded to India or Pakistan. ${ }^{15}$ The States of Hyderabad and Junagadh were incorporated by force into India and the armed conflict in Jammu and Kashmir resulted in dividing the State between the two countries. In all, a total of 13 princely states, excluding the State of Jammu and Kashmir, became part of Pakistan. ${ }^{16}$

In March 1955, as a prelude to the 1956 Constitution of Pakistan, the then Governor General Ghulam Muhammad established a One Unit Scheme under which western provinces of Balochistan, North West Frontier Province, Punjab and Sindh were merged together into a

Province with no legislative assembly and administered by Chief Commissioner appointed by the Federal Government.

${ }^{13}$ Blood, Peter R. Pakistan: A Country Study, 6th ed. (Washington D.C.: Federal Research Division, 1995)32- 33

${ }^{14}$ Mohiuddin, Yasmin N., Pakistan: A Global Studies Handbook (Santa Barbara: ABC-CLIO Inc, 2007): 76

${ }^{15} \mathrm{Ibid}$,

${ }^{16}$ Also see: Coplan, I., "The Princely States, the Muslim League, and the Partition of India in 1947," The International History Review, Vol. 13, No. 1 (1991): 38 - 69 
single province called West Pakistan. ${ }^{17}$ As Talbot writes, the main objective of the One Unit Scheme was to "give parity between a unified West Pakistan province and East Pakistan."18 In a 1955 essay, a year before the promulgation of the first Constitution, Choudhury narrates the dilemmas of constitution-making the Country had to face in first nine years of its existence: ${ }^{19}$

Representation between East and West Pakistan in the federal legislature was the problem which, more than any other, delayed the framing of a constitution. Pakistan consists of two parts separated by a thousand miles of foreign (Indian) territory. East Pakistan is one-seventh of the whole in area, but its population exceeds the total population of all the provinces and states in West Pakistan. In other words, Pakistan is a curiously dual state with most of its area in the West and most of its population in the East... To find a common parliament for a state, whose territory and population are so uniquely distributed, proved to be a complex task.

The second Constituent Assembly, which had assumed office on June 21, 1955, adopted the first Constitution of Pakistan on February 29, 1956. The Constitution retained the One Unit System and addressed the representational issue in federal legislature between the East and West wings of Pakistan through parity in the National Assembly that consisted of 300 members. The second post-independence Constitution of Pakistan, promulgated on March 1,

\footnotetext{
${ }^{17}$ On April 27, 1955, the Governor General of Pakistan issued an Order whereby the strength of the Constituent Assembly was fixed at 80 and divided equally between East Pakistan and the provinces of Punjab, NWFP, Sind and Baluchistan, the Frontier States and Tribal Areas and states of Khairpur, and Bahawalpur and the capital city of Karachi.

${ }^{18}$ Talbot, I., "The Punjabization of Pakistan: Myth or Reality?” in Christopher Jaffrelot (ed.) Pakistan: Nationalism without a Nation (London: Zed Books, 2002): 58

${ }^{19}$ Choudhury, G.W., "Constitution-making Dilemmas in Pakistan," The Western Political Quarterly, Vol. 8, No. 4 (1955): 592
} 
1962, also retained the One Unit System and parity now in the form 80,000 called electors 'basic democrats' divided equally between the two provinces. The One Unit System finally came to an end on March 30, 1970 when General Yahya Khan issued a Legal Framework Order and reconstituting the original four provinces in West Pakistan. ${ }^{20}$

After the secession of East Pakistan into Bangladesh, the third Constitution of Pakistan was enacted on April 12, 1973 under the Presidency of Zulfikar Ali Bhutto, which came into effect on August 14, 1973. The Clause 2 of Article 1 of the Constitution laid down the federating units of Pakistan as "(a) the Provinces of Baluchistan, the North-West Frontier, the Punjab and Sind; (b) the Islamabad Capital Territory, hereinafter referred to as the Federal Capital; (c) the Federally Administered Tribal Areas; and (d) such States and territories as are or may be included in Pakistan, whether by accession or otherwise." The Clause 3 of Article 1 further stated that "The Constitution shall be appropriately amended so as to enable the people of the Province of East Pakistan, as and when foreign aggression in that Province and its effects are eliminated, to be represented in the affairs of the Federation," which was later taken out from the Constitution with the First Amendment. After being amended by the First Amendment and most recently by the Eighteenth Amendment, Clause 2 of Article 1 titled "The Republic and its Territories" now reads as " The territories of Pakistan shall comprise :(a) the Provinces of Balochistan, the Khyber Pakhtunkhwa, the Punjab and Sindh; (b) the Islamabad Capital Territory, hereinafter referred to as the Federal Capital; (c) the Federally Administered Tribal Areas; and (d) such States and territories as are or may be included in Pakistan, whether by accession or otherwise.",21

\footnotetext{
${ }^{20}$ Baxter, C., "Constitution Making: The Development of Federalism in Pakistan," Asia Survey, Vol. 14, No. 12 (1974): 1077

${ }^{21}$ Clause 2, Article 1, the 1973 Constitution of Pakistan
} 
Under the "Fundamental Rights," the Article 7 of the 1973 Constitution of Pakistan defines the "State" as "the Federal Government, Majlis-e-Shoora (Parliament), a Provincial Government, a Provincial Assembly, and such local or other authorities in Pakistan as are by law empowered to impose any tax or cess." 22 Under the "Principles of Policy," the Article 32 of the Constitution of Pakistan encourages the "Promotion of local Government institutions," and calls upon the State to "encourage local Government institutions composed of elected representatives of the areas concerned and in such institutions special representation will be given to peasants, workers and women." It is important to note that the articles prescribed under the "Principals of Policy" are not binding upon the state, as Clause 2 of the Article 29 states, "In so far as the observance of any particular Principle of Policy may be dependent upon resources being available for the purpose, the Principle shall be regarded as being subject to the availability of resources," and Clause 1 of Article 30 further states that "The responsibility of deciding whether any action of an organ or authority of the State, or of a person performing functions on behalf of an organ or authority of the State, is in accordance with the Principles of Policy is that of the organ or authority of the State, or of the person, concerned." Therefore establishing local governments as an organ of the State was never a Constitutional imperative until the Seventeenth Amendment to the Constitution validating the Legal Framework Order 2002 that had inserted Article 140A stating "Each Province shall, by law, establish a local government system and devolve political, administrative and financial responsibility and authority to the elected representatives of the local governments. $" 23$

\footnotetext{
${ }^{22}$ Article 7, the 1973 Constitution of Pakistan

${ }^{23}$ Legal Framework Order, 2002 (Chief Executive's Order No. 24 of 2002), Article 3(1), Sch. item 16
} 
Brief history of local governments in Pakistan is discussed in more detail in subsequent sections of this chapter, but they now have the Constitutional cover and constitute the State of Pakistan (see table 5.1). ${ }^{24}$

\section{4: THE BRANCHES OF THE GOVERNMENT OF PAKISTAN}

The 1973 Constitution of Pakistan enshrines the trichotomy of power between the three organs of the State, namely the legislature, the executive and the judiciary. ${ }^{25}$ While addressing a delegation of the National Defence College at the Supreme Court of Pakistan, the Chief Justice of Pakistan Justice Iftikhar Muhammad Chaudhry highlights the very principle, "the Constitution of Pakistan envisages trichotomy of powers between the three organs of the state, namely, the legislature, the judiciary and the executive. All three branches of the government have their different and distinct roles and functions. However, in the performance of their functions, the three branches are not rivals, but supplemental to each other, to further the aims and objectives of the polity." ${ }^{, 26}$ Ahmed and Khwaja write that one of the elements, which define democratic quality in Pakistan, is "trichotomy of power between executive, judiciary and legislature." ${ }^{27}$ In this section, the constituting features of the three organs of the State of Pakistan are briefly discussed.

\footnotetext{
${ }^{24}$ For discussion on challenges and constraints on federalism in Pakistan, see: Shah, Azmat A., "Federalism Constraints and Opportunity in Pakistan," African Journal of Political Science and International Relation, Vol. 7, No. 2 (2013): 79 - 99; Waseem, M., "Pakistan: A MajorityConstraining Federalism," India Quarterly: A Journal of International Affairs, Vol. 67, No. 3 (2011): 213 - 228; Adeney, K., "A Step Towards Inclusive Federalism in Pakistan? The Politics of the 18th Amendment," The Journal of Federalism, Vol. 42, No. 4 (2012): 539 - 565

${ }^{25}$ See: Sial, Abdul Quddoos, "Implications of Assorted Constitutional Principles on Administration of Justice in Pakistan," Pakistan Journal of Social Sciences, Vol. 31, No. 2 (2011): 230 - 232

${ }^{26}$ Khan, Iftikhar A., "Organs of the State are Not Rivals," Dawn (Daily), February 25, 2007

${ }^{27}$ Ahmed, S., and Khwaja, S. Z., "Pakistan - A Struggle with Democracy: An Analysis about the Democratic Quality of Pakistan," International Journal of Social Ecology and Sustainable Development, Vol. 4, No. 1 (2013): 108
} 


\subsection{1: THE LEGISLATIVE BRANCH}

At the federal level, the Constitution of Pakistan provides for a bicameral legislature consisting of the National Assembly (the Lower House) and the Senate (the Upper House). The National Assembly consists of 342 seats that include 60 seats reserved for women and 10 for non-Muslims. The general, as well as the reserved seats for women, are allocated on the basis of population to each Province, FATA and ICT in accordance with the last preceding census officially published. ${ }^{28}$ The 10 reserved seats for non-Muslims are not distributed to the provinces but are representative for the whole of Pakistan. ${ }^{29}$ Members of the National Assembly are elected on the basis of single-member geographic constituencies by direct vote through a first-past-the-post or simple majority system. Members to the reserved seats allocated women and non-Muslims are elected through proportional representation system of political parties' lists of candidates on the basis of the total number of general seats secured by each political party in the National Assembly (see table 5.2).

The Senate, or the Upper House of Pakistan, consists of 104 members, where each Provincial Assembly elects 23 Senators including four reserved seats for women, four reserved seats for technocrats and one reserved seat for Non-Muslim. The remaining 12 members, eight from FATA and four from the Federal Capital, are elected by the order of the President. The 92 seats allocated to the four provinces are elected through the system of proportional representation by means of the single transferable vote by their respective Provincial Assemblies. The reason for a bicameral parliamentary system at the Federal Level is to provide equal representation to all the federating units of Pakistan, as opposed to the National Assembly where members are divided among provinces and regions on the basis of their

\footnotetext{
${ }^{28}$ Article 5, the 1973 Constitution of Pakistan

${ }^{29}$ Clause C of Article 6, the 1973 Constitution of Pakistan
} 
respective population. The Senate is a permanent legislative body; the term of its members is however six years, as opposed to five-year term of the members of the national assembly, where half of its members retire after every three years.

At the provincial level, the Constitution of Pakistan provides for a unicameral legislature. It is important to note, as Valentine recounts, Pakistan initially also had a unicameral Parliament at the centre under the first Constitution adopted in 1956. Even under the second Constitution adopted in 1962, the unicameral parliamentary system was retained however the parliamentary sessions were held both at Dhaka (then East Pakistan) and in Rawalpindi (then West Pakistan), near to the newly planned capital of Islamabad until the Parliament was completely moved to Dhaka in 1966. It was only after the secession of East Pakistan into Bangladesh and subsequent promulgation of the 1973 Constitution that a bicameral legislature at the Centre was formed. ${ }^{30}$ As noted above, the reason for a bicameral legislature at the Centre was to give equal representation to the federating units in the National Parliament. The Article 106 of the Constitution of Pakistan demarcates constitution of provincial assemblies consisting of "general seats and seats reserved for women and nonMuslims" (see table 5.2 for the number of seats in the four provincial parliaments). The elections to the general and reserved seats of provincial assemblies are held together and on the same lines as for the federal legislature. The term for both federal and provincial legislature is prescribed in the Constitution for five years. ${ }^{31}$

As noted above, the Constitution of Pakistan prescribes the third legislative body as the "local government," wherein Article 140A calls upon each provincial government to "establish a

\footnotetext{
${ }^{30}$ Valentine, E., "Pakistan Parliamentary Libraries: A Historical Excursion and Hopes for the Future," Library Trends, Vol. 58, No. 4 (2010): 529

${ }^{31}$ Clause 3, Article 106, the 1973 Constitution of Pakistan
} 
local government system and devolve political, administrative and financial responsibility and authority to the elected representatives of the local governments." In sub-clause 2 of the same Article it further states "Elections to the local governments shall be held by the Election Commission of Pakistan." President Ayub Khan, following his imposition of the first martial law in 1958, first introduced local government system. Under the Basic Democracies Ordinance of 1959 and the Municipal Administration Ordinance of 1960, Ayub introduced a local government system as the only representative tier of the government. Ayub himself explains this system in length to which he calls "Basic Democracies," where Basic Democrats were to be elected through direct elections at roughly 80,000 local councils divided equally between the two wings of Pakistan - East and West. ${ }^{32}$ When Ayub promulgated the second post-independence Constitution of Pakistan on March 1, 1962 after forty-four months of Martial Law, he not only transformed the government into a unicameral legislative and a presidential form of system but also provided constitutional status to Basic Democrats by declaring them as the Electoral College for the election of the President and national and provincial assemblies. Thereafter, the local government system has been revived twice both under the military rules, first by General Zia-ul-Haq through the Local Government Ordinance of 1979 and later introduced by General Pervez Musharraf under the Local Government Ordinance of 2001. After the General Elections of 2008 and subsequent resignation of then President General Pervez Musharraf, the local government system introduced in 2001 was put in abeyance. The provincial governments elected in 2008 General Elections postponed local government elections scheduled to be held in 2009 and suspended the system completely in 2010. Importantly, the Seventeenth amendment to the Constitution in 2003 during the tenure of General Musharraf had not only legitimise his takeover but had also validated the Article 140A instituted by the Legal Framework Order of 2002 which

\footnotetext{
${ }^{32}$ See: Khan, Muhammad A., "A new experiment in democracy in Pakistan," Annals of the American Academy of Political and Social Sciences, Vol. 358 (1965): 109 - 113
} 
stipulated, "Each Province shall, by law, establish a local government system and devolve political, administrative and financial responsibility and authority to the elected representatives of the local governments," effectively providing constitutional cover to the subject. ${ }^{33}$ The Eighteenth Amendment to the Constitution deliberated by the elected civilian government in 2010, with the consensus of other political factions in the Parliament, to repeal amendments made by General Musharraf during his tenure, especially the Seventeenth Amendment. In its preamble, the Eighteenth Amendment stated, "it is necessary that the Legal Framework Order, 2002, as amended by the Chief Executive's Order No. 29 and the Chief Executive's Order No. 32 of 2002, be declared as having been made without lawful authority and of no legal effect, and the Constitution (Seventeenth Amendment) Act, 2002 (Act No. III of 2003), be repealed and the Constitution further amended to achieve the aforesaid objectives." It, however, reinstated Article 140A on local government and made a constitutional imperative. Hussain, in his article, sums up the ensuing state of affairs whereby "the four provincial governments have successfully avoided holding local government elections for the last four years due to reasons ranging from the lack of consensus on a local government model that suits the province (Sindh), the fear of challenge and competition in a crowded electoral arena (Punjab) and the law and order situation (Khyber Pakhtunkhwa and Balochistan)... but the possibility of further delay is seriously hampered by Supreme Court activism." ${ }^{34}$ It was then essentially the Supreme Court of Pakistan that instructed the provincial government in April 2012 to hold local government elections "without delay." ${ }^{, 35}$ In July 2013, the Supreme Court directed the Federation and the four Provincial Governments to provide a definitive date for holding local government elections within 90 days and ruled that efforts should be made the local bodies elections are held across the country close to

\footnotetext{
${ }^{33}$ Hussain, A., "Not so Local," Herald (September 13, 2013)

${ }^{34}$ Ibid

${ }^{35}$ Nishtar, S., "Local Imperatives,” The News (daily), Thursday, November 7, 2013
} 
September 15, 2013 after promulgating the relevant laws. ${ }^{36}$ The ruling specifically asked the Provincial Governments to pass their respective Local Government Laws by August 15 in order for the elections to be conducted by the deadline. It was then only made possible because of Supreme Court's direct intervention that the provinces moved forward on Local Government legislation. ${ }^{37}$ As a result the Sindh Assembly passed the Sindh Local Government Act on August 19, 2013, the Provincial Assembly in Punjab passed the Punjab Local Government Act on August 21, 2013 and the Balochistan Local Government (Amendment) Act was passed by the Assembly on August 30, 2013. The provincial government of KP could only pass the Khyber Pakhtunkhwa Local Government Act 2013 in November 2013 (a comparative analysis of all four bills is provided in table 5.3). By the end of 2013, only the provincial government in Balochistan was able to hold local body elections. The latest ruling by the Supreme Court of Pakistan has come on March 19, 2014 ordering the Election Commission of Pakistan to ensure the holding of the local body elections in all provinces are completed by November $14,2014 .^{38}$

\subsection{2: THE EXECUTIVE BRANCH}

At the federal level, the executive branch comprises the offices of the President and the Prime Minister, the Cabinet together with Ministries and Division that fall into it and all administrative arms of the government that include attached departments, subordinate offices and autonomous and semi-autonomous bodies. The Clause 1 of the Article 41 of the Constitution of Pakistan stipulates, "There shall be a President of Pakistan who shall be the

\footnotetext{
${ }^{36}$ Khan, S., "SC Directs Provinces, ICT to Ensure LB Polls by Sept 15," The News (Daily), Tuesday, July 23, 2013

${ }^{37}$ Pakistan Institute of Legislative Development and Transparency, Assessment of the Quality of Democracy in First 100 Days of National and Provincial Governments (Islamabad: Pildat, 2013): 33

${ }^{38}$ Sigamony, Terence J., "SC Orders LG Polls by Nov 15," The Nation (daily), Thursday, March 20, 2014
} 
Head of State and shall represent the unity of the Republic." The Sub-Clause 2 of the same article defines the parameters for the election of the President whereby members of both the upper and lower houses of the National Parliament as well as members of the four provincial assemblies constitute the Electoral College. The Article 90 of the Constitution of Pakistan further delineates the executive branch of the federal government "the executive authority of the Federation shall be exercised in the name of the President by the Federal Government, consisting of the Prime Minister and the Federal Ministers, which shall act through the Prime Minister, who shall be the chief executive of the Federation," and "In the performance of his functions under the Constitution, the Prime Minister may act either directly or through the Federal Ministers." ${ }^{39}$ The Electoral College for the position of Prime Minister consists of the total membership of the National Assembly alone. The Article 91 describes the Cabinet as consisting of "Ministers, with the Prime Minister at its head, to aid and advise the President in the exercise of his functions." 40 The sub-clause 6 of the Article 91 makes the Cabinet, together with the Ministers of State, collectively responsible to the National Parliament. The Rules of Business 1973 defines Ministry as a division or group of divisions constituted into a ministry or it may comprise one or more divisions for the conduct of business of Federal Government in a specified sphere and headed by a Cabinet Minister with a Secretary as its administrative charge. The Division is headed by a Minister of State and, defined as, "a selfcontained administrative unit responsible for the conduct of business of the Federal Government in a distinct and specified sphere and declared as such by the Federal Government." It performs functions like Ministry in the formulation of policies and to ensure their implementation with either Secretary or the Additional Secretary as its administrative in-charge. $^{41}$

\footnotetext{
${ }^{39}$ Article 90, the 1973 Constitution of Pakistan

${ }^{40}$ Clause 1, Article 91, the 1973 Constitution of Pakistan

${ }^{41}$ Clause VI of Para 2 of Part A, Rules of Business 1973
} 
At the provincial level, the Governor, the Chief Minister and the Provincial Cabinet replace the offices of the President, Prime Minister and the Federal Cabinet respectively with civil service as its administrative wing. The Article 101 of the Constitution of Pakistan states "There shall be a Governor for each Province, who shall be appointed by the President on the advice of the Prime Minister." 42 The Article 129 states "the executive authority of the Province shall be exercised in the name of the Governor by the Provincial Government, consisting of the Chief Minister and Provincial Ministers, which shall act through the Chief Minister. ${ }^{43}$ The Article 130 demarcates the Provincial Cabinet consisting "of Ministers, with the Chief Minister at its head, to aid and advise the Governor in the exercise of his functions." ${ }^{44}$ In terms of the administrative relation between the Federation and Provinces, the Article 148 and the Article 149 are important that respectively state "The executive authority of every Province shall be so exercised as to secure compliance with Federal laws which apply in that Province," and "the executive authority of every Province shall be so exercised as not to impede or prejudice the exercise of the executive authority of the Federation, and the executive authority of the Federation shall extend to the giving of such directions to a Province as may appear to the Federal Government to be necessary for that purpose." 45 The Article 139 of the Constitution of Pakistan specifies "conduct of business of provincial governments," in three sub-clauses. The Sub-Clause 2 states that "The [Provincial Government] shall by rules specify the manner in which orders and other instruments made and executed in his name shall be authenticated, and the validity of any order or instrument so authenticated shall not be questioned in any court on the ground that it was not made or executed by the Governor," and the Sub-Clause 3 further specifies that "The Provincial

\footnotetext{
${ }^{42}$ Clause 1, Article 101, the 1973 Constitution of Pakistan

${ }^{43}$ Clause 1, Article 129, the 1973 Constitution of Pakistan

${ }^{44}$ Clause 1, Article 130, the 1973 Constitution of Pakistan

${ }^{45}$ Clause 1, Article 148 and Article 149, the 1973 Constitution of Pakistan
} 
Government shall also make rules for the allocation and transaction of its business." ${ }^{46}$ In exercise of this power, the four provincial governments have set fourth their respective rules of business. The Provincial Government of Balochistan notified its latest rules of business on December 14, 2012, the Provincial Government of Khyber Pakhtunkhwa operates through the rules first notified on April 6, 1985 with subsequent amendments, the Provincial Government of Punjab notified its latest rules on March 11, 2011 and the Provincial Government of Sindh rules are first notified on August 13, 1988. These rules of businesses of the four provincial governments define the distribution of functions among the departments of their respective government and set forth the procedure for disposal of work (see table 5.4 for the summary description of general contents of provincial rules of businesses).

At the local level, the executive authority rests with the elected Chairman and the Vice Chairman of councils at different levels in the provinces of Balochistan, Punjab and Sindh and with the Nazim [Mayor] and the Naib Nazim [Deputy Mayor] in Khyber Pakhtunkhwa province. The Article 64 of the Punjab Local Government Act 2013 specifies the executive authority of a local government to be vested in and be exercised by its Mayor or Chairman. ${ }^{47}$ In similar lines, the Article 79 of the Sindh Local Government Act 2013 specifies "the executive powers of a Council shall vest in and be exercised by its Mayor or Chairman, as the case may be, either directly or through any person authorised by him in accordance with the rules." ${ }^{48}$ In Balochistan Local Government Act, the Article 63 states similarly "the executive authority of Local Council shall vest in and be exercised by its Chairman or Mayor as the case may be." ${ }^{49}$ In Khyber Pakhtunkhwa Local Government Act 2013, the executive

\footnotetext{
${ }^{46}$ Article 139, the 1973 Constitution of Pakistan

${ }^{47}$ Clause 2, Article 64, the Punjab Local Government Act 2013

${ }^{48}$ Clause 2, Article 79, the Sindh Local Government Act 2013

${ }^{49}$ Clause 2, Article 63, Balochistan Local Government (Amendment) Act No V 2011
} 
authority is with the Nazim [Mayor] who are elected at three tiers, namely district, subdistrict and village or neighbourhood levels. ${ }^{50}$

\subsection{3: THE JUDICIAL BRANCH}

The judicial branch consists of the Supreme Court, High Courts and other lower courts, created by the Acts of Parliament of Provincial Assemblies with civil and criminal jurisdiction. The Constitution of Pakistan provides for "separation of judiciary from the executive" and the "independence of the judiciary."51 The Article 175 of the Constitution of Pakistan states "There shall be a Supreme Court of Pakistan, a High Court for each Province and a High Court for the Islamabad Capital Territory and such other courts as may be established by law." ${ }^{52}$ The Chief Justice heads the Supreme Court as per the Article 176, which states "The Supreme Court shall consist of a Chief Justice to be known as the Chief Justice of Pakistan and so many other Judges as may be determined by Act Majlis-e-Shoora (Parliament) or, until so determined, as may be fixed by the President.” The Clause 1 of Article 192 states similarly for provinces that "A High Court shall consist of a Chief Justice and so many other Judges as may be determined by law or, until so determined, as may be fixed by the President." The Supreme Court of Pakistan, as introduced to visitors on its website:

“...Exercises original, appellate and review jurisdiction. It possesses exclusive original jurisdiction for the settlement of intergovernmental disputes between Federal and Provincial Government(s) or Provincial

\footnotetext{
${ }^{50}$ Clause 2, Article 1 and Article 21; Clause 4, Article 27, Khyber Pakhtunkhwa Local Government Act 2013

${ }^{51}$ Article 2A, the Objective Resolution, the 1973 Constitution of Pakistan

${ }^{52}$ Article 175, the 1973 Constitution of Pakistan
} 
Governments inter se. Under this jurisdiction, the Court pronounces declaratory judgments. The Supreme Court can also exercise original jurisdiction, with respect to the enforcement of fundamental rights, if the case involves an issue of public importance. The Court also exercises advisory jurisdiction, where under the President may obtain its opinion on a question of law. Under its appellate jurisdiction, the Court entertains appeals against orders and decisions of High Courts and other special courts/tribunals.”

In addition to the Supreme Court at the federal level, the Article 203C of the Constitution of Pakistan also provides for the establishment of a Federal Shariat Court. The Clause 1 of the Article 203D specifies the power, jurisdiction, and function of the Federal Shariat Court that it "may, either of its own motion or on the petition of a citizen of Pakistan or the Federal Government or a Provincial Government, examine and decide the question whether or not any law or provision of law is repugnant to the injunctions of Islam, as laid down in the Holy Quran and Sunnah of the Holy Prophet, hereinafter referred to as the Injunctions of Islam." In the same Article, Clause 3 stipulates that "If any law or provision of law is held by the Court to be repugnant to the Injunctions of Islam, (a) the President in the case of a law with respect to a matter in the Federal Legislative List or the Concurrent Legislative List, or the Governor in the case of a law with respect to a matter not enumerated in either of those Lists, shall take steps to amend the law so as to bring such law or provision into conformity with the Injunctions of Islam; and (b) such law or provision shall, to the extent to which it is held to be so repugnant, cease to have effect on the day on which the decision of the Court takes effect." 53

${ }^{53}$ Clause 3, Article 203D, the 1973 Constitution of Pakistan 
Mughal sums up the role of the senior judiciary in Pakistan in maintaining balance of power in the judgment of Justice Saleem Akhtar, then a judge of the Sindh High Court, who had observed that "In a set-up where the Constitution is based on trichotomy of power, Judiciary enjoys a unique and supreme position within the framework of the Constitution as it creates balance amongst various organs of the State and also checks the excessive and arbitrary exercise of power by the Executive and the Legislature." ${ }^{, 54}$

\section{5: THE PROCESS OF PUBLIC POLICY MAKING IN PAKISTAN}

In order to understand the formal public policy making process in Pakistan, this section makes further dissection of the Constitution of Pakistan in respect to the three pillars of the state, namely the legislature, the judiciary and the executive.

\subsection{1: THE LEGISLATURE}

According to the constitutional scheme, writes Khan, the Parliament and the provincial assemblies are at the centre stage of Pakistan's democratic aspirations. ${ }^{55}$ The Article 70 of the Constitution of Pakistan prescribes legislative procedure of the National Assembly that "A Bill with respect to any matter in the Federal Legislative List may originate in either House and shall, if it is passed by the House in which it originated, be transmitted to the other House; and, if the Bill is passed without amendment, by the other House also, it shall be

\footnotetext{
${ }^{54}$ Mughal, Munir A., Legal and Judicial Education Reforms in Pakistan: Role of Legislature, Judiciary and Executive (Lahore: Munib Book House, 2013): 147 - 148

${ }^{55}$ Khan, Z., "Constitutional Reforms in Pakistan: Federalism after the 18th Amendment," in Christian J. Hegemer and Hanns Bühler (eds.) Federalism in Asia and Beyond (München: Hanns-Seidel-

Stiftung, 2013): $193-215$
} 
presented to the President for assent. ${ }^{, 56}$ In Article 75, the Constitution further states that" When the President has assented or is deemed to have assented to a Bill, it shall become law and be called an Act of Majlis-e-Shoora (Parliament). ${ }^{, 57}$ The Article 142 categorises legislative powers of the Federal and Provincial assemblies and states "Majlis-e-Shoora (Parliament)] shall have exclusive power to make laws with respect to any matter in the Federal Legislative List," and the "power to make laws with respect to criminal law, criminal procedure and evidence," as well as "with respect to all matters pertaining to such areas in the Federation as are not included in any Province." ${ }^{58}$ The Fourth Schedule of the Constitution of Pakistan contains the "Federal Legislative List" in two parts. While Part-I of the Federal Legislative List is purely the prerogative of the Federal Government, Part-II falls in the domain of the Council of Common Interest. Part-I of the Federal Legislative List given in the Fourth Schedule of the Constitution comprises a total of 59 legislative matters from defence, military and external affairs to nationality, currency, international treaties and others. Part-II of the Federal Legislative List consists of 17 legislative matters, where the Federation and the Provinces both have joint jurisdiction, including railways, minerals, electricity, ports, census and others. The Article 153 of the Constitution of Pakistan states that "There shall be a Council of Common Interest...to be appointed by the President," and consisting of the Prime Minister as the Chairman of the Council, the Chief Ministers of the Provinces and three members from the Federal Government who are appointed by the Prime Minister. ${ }^{59}$ The Article 154 details functions and rules of procedures of the Council of Common Interest and its first clause states that "The Council shall formulate and regulate policies in relation to matters in Part II of the Federal Legislative List and shall exercise supervision and control over related institutions." Importantly, decisions taken by the Council are expression of

\footnotetext{
${ }^{56}$ Clause 1, Article 70, the 1973 Constitution of Pakistan

${ }^{57}$ Clause 3, Article 75, the 1973 Constitution of Pakistan

${ }^{58}$ Clauses a, b, and d, Article 142, the 1973 Constitution of Pakistan

${ }^{59}$ Clauses 1 and 2, Article 153, the 1973 Constitution of Pakistan
} 
majority of its members and, as per Clause 7 of the Article 154, "If the Federal Government or a Provincial Government is dissatisfied with a decision of the council, it may refer the matter to Majlis-e-Shoora (Parliament) in a joint sitting whose decision in this behalf shall be final. A money bill can, however, be originated only in the National Assembly and its copy is sent to the Senate which makes recommendations, if any, within 14 days to the National Assembly. These recommendations are not binding upon the National Assembly, as per the Article 73, "The National Assembly shall consider the recommendations of the Senate and after the Bill has been passed by the Assembly with or without incorporating the recommendations of the Senate, it shall be presented to the President for assent." Clause 2 of the Article 175 explains procedures when the President returns a proposed bill for assent to the Parliament, for which a 10-day duration is stipulated, the bill is then reconsidered by the Parliament in joint sitting and as stated “...if it is again passed, with or without amendment, by the Majlis-e-Shoora (Parliament), by the votes of the majority of the members of both Houses present and voting; it shall be deemed for the purposes of the Constitution to have been passed by both Houses and shall be presented to the President, and the President shall give his assent within ten days, failing which such assent shall be deemed to have been given." In such a scenario, again, the final decision lies with the legislature to comply or not to the President's reconsideration to the proposed bill. ${ }^{60}$

At the province levels, the Article 142 of the Constitution states that "Provincial Assembly shall have power to make laws with respect to criminal law, criminal procedure and evidence" and the "power to make laws with respect to any matter not enumerated in the Federal Legislative List.” The Articles 143 give supremacy to the Federal Legislature over the Provincial Legislature and state "If any provision of an Act of a Provincial Assembly is

\footnotetext{
${ }^{60}$ Clauses 1 and 2, Article 75, the 1973 Constitution of Pakistan
} 
repugnant to any provision of an Act of Majlis-e-Shoora (Parliament) which Majlis-e-Shoora (Parliament) is competent to enact, then the Act of Majlis-e-Shoora (Parliament), whether passed before or after the Act of the Provincial Assembly, shall prevail and the Act of the Provincial Assembly shall, to the extent of the repugnancy, be void." ${ }^{\prime 61}$ As per the Article 116, a bill passed by the provincial assembly is presented to the Governor of the province for assent and "When the Governor has assented or is deemed to have assented to a Bill, it shall become law and be called an Act of Provincial Assembly.",62

At the local bodies' level, the Constitution makes it the prerogative of the provincial governments to establish local governments and by law devolve political, administrative and financial responsibility and authority to the elected representative. The elections to the local government, however, are the responsibility of the Election Commission of Pakistan for the whole of the Country. ${ }^{63}$ As a result, there is a degree of variation in the existing local government acts of the provincial governments. For instance, the Article 76 of the Punjab Local Government Act 2013 allows District Councils to "approve bye-laws and taxes," and the Article 77 allows certain regulatory powers such as regulation of "dangerous and offensive articles and trades," "excavation of earth, sand, stones or other material," and “establishment of brick kilns, potteries and other kilns.” The Article 145 of the Punjab Local Government Act 2013 further explains the authority of the local government to make "byelaws" that "A local government may, and if required by the Government shall, make byelaws not inconsistent with this Act and the rules to give effect to the provisions of this Act," and as per Clause 3 of the same Article "the bye-laws may provide for all or any of the

\footnotetext{
${ }^{61}$ Article 143, the 1973 Constitution of Pakistan

${ }^{62}$ Clauses 1 and 4, Article 116, the 1973 Constitution of Pakistan

${ }^{63}$ Article 140A, the 1973 Constitution of Pakistan
} 
matters specified in Part-II of Seventh Schedule. ${ }^{64}$ The Part-11 of Seventh Schedule of the Punjab Local Government Act contains 31 items from building control and prevention and removal of encroachment to licencing and plantation. The local governments, however, operate within the provincial framework as Article 4 of the Punjab Local Government Act 2013 states that "The local governments established under this Act shall function within the Provincial framework and shall faithfully observe the Federal and Provincial laws," and "In the performance of their functions, the local governments shall not impede or prejudice the exercise of the executive authority of the Government." The Article 120 further states that "The [Provincial] Government may, on the recommendations of the Punjab Local Government Commission, issue directions to a local government and the local government shall be bound by such directions," and "Where the situation demands immediate action and the local government fails to comply with the directions given to it under subsection, the Government may direct the officer authorised by it to take such action as the situation may necessitate. ${ }^{, 65}$ It is important to note that the Punjab Local Government Commission does not have the representation of the elected local government representatives and its members include Minister for Local Government, three members of the Provincial Assembly, two technocrats also nominated by the Government and the Secretary Local Government and Community Development Department. ${ }^{66}$ The local government acts in other provinces are in similar lines.

Bashir summarises the legislative policy process in Pakistan whereby federal and provincial representatives brining policy issues, based on their party manifesto or the wishes of their constituents, to the attention of federal or provincial legislative bodies. Once passed, the

\footnotetext{
${ }^{64}$ Article 145, the Punjab Local Government Act 2013

${ }^{65}$ Article 120, the Punjab Local Government Act 2013

${ }^{66}$ Article 122, the Punjab Local Government Act 2013
} 
resolution is tabled to a standing committee who bring their recommendation back to the legislative body in the form of a bill, which upon passage becomes policy as an act of the government. ${ }^{67}$ Table 5.5 provides a simplified snapshot of the process of legislative law making in the National Parliament and Provincial Assemblies of Pakistan.

\subsection{2: THE EXECUTIVE}

As per the Rules of Business of 1973 of the Government of Pakistan, it is the mandate of the executive branch of the government to formulate policies and undertake policy decisions. ${ }^{68}$ As per the Article 90 of the Constitution, the executive authority is exercised by the Federal Government and in the name of the President, which consists of the Prime Minister and the Federal Ministers. ${ }^{69}$ In provinces, the executive authority is exercised in the name of the Governor by the Provincial Government, which consists of the Chief Minister and Provincial Ministers. ${ }^{70}$ According to the Rules of Business of 1973 of the Government of Pakistan, the Secretary is designated as the official head and a principal account officer of a division or a ministry with the responsibility to assist the minister-in-charge in formulation and implementation of policies. ${ }^{71}$ Constitutionally, the Executive Branch of the Government decides which issues are to be presented for the consideration of the parliament. ${ }^{72}$ The Article 90 of the Constitution grants the executive power to the Federal Government by specifying that "...orders and other instruments made and executed in the name of the President shall be authenticated, and the validity of any order or instrument so authenticated shall not be

\footnotetext{
${ }^{67}$ Bashir, M.., "Public Policy Processes and Citizen Participation in Pakistan," in Meghna Sabharwal (ed.) Public Administration and Public Policy: Public Administration in South Asia: India, Bangladesh and Pakistan (London: CRC Press, 2013): 403

${ }^{68}$ Khan, Z., 2013: 207

${ }^{69}$ Clause 1, Article 90, the 1973 Constitution of Pakistan

${ }^{70}$ Clause 1, Article 129, the 1973 Constitution of Pakistan

${ }^{71}$ Khan, Z., 2013: 207

${ }^{72}$ Sapru, R. K., Public Policy: Formulation, Implementation and Evaluation, 2nd ed. (New Delhi: Sterling, 2004): 138
} 
questioned in any court on the ground that it was not made or executed by the President." ${ }^{, 73}$ As per the Article 139, similar powers are vested in the provincial governments. The Article 148 of the Constitution of Pakistan further states, "The executive authority of every Province shall be so exercised as to secure compliance with Federal laws which apply in that Province. ${ }^{, 74}$ Bashir writes that the most common policy process in Pakistan is top-down in which civil servants based on the executive decisions of a political leader draft policy. It is formulated in the form of an official document called 'summary' and when signed by the concerned executive authority it is despatched to the relevant governmental organisations for implementation. ${ }^{75}$ Khawaja, in his analysis of formulation and implementation of policy in Pakistan observes that only after the ownership of a certain public policy by the Government through an enactment, cabinet decision or approval of the concerned administrative authority can it be called a 'public policy. ${ }^{, 76}$ By taking the example of health policy, Khawaja highlights the top-down approach to public policy making in Pakistan starting from formulation of a draft policy by the concerned ministry and submitting it to the Ministry of Finance and Planning Commission for comments, and in light of those comments, if any, submission of the final policy draft to the Cabinet for its approval. The final policy document, incorporating comments of the Cabinet if there were any, is then presented to the National Assembly more for the purpose of information than for an approval. ${ }^{77}$ This broader policy documents then lays out fundamentals and proposals for more precise public policy outcomes.

\footnotetext{
${ }^{73}$ Clause 2, Article 90, the 1973 Constitution of Pakistan

${ }^{74}$ Clause 1, Article 148,

${ }^{75}$ Bashir, M.., 2013: 403

${ }^{76}$ Khawaja, S., Public Policy: Formulation Implementation Analysis: Pakistan Focused (Islamabad: Mr. Books, 2013): 102

${ }^{77}$ Ibid, $89-92$
} 
The Constitution of Pakistan also provides power to the President to promulgate ordinances at the federal level and to the Governor in provinces. As per the Article 89 of the Constitution of Pakistan the President "except when the Senate or National Assembly is in session, if satisfied that circumstances exist which render it necessary to take immediate action, make and promulgate an Ordinance, as the circumstances may require." The same Article further states, "An Ordinance promulgated under this Article shall have the same force and effect as an Act of Majlis-e-Shoora (Parliament) and shall be subject to like restrictions as the power of Majlis-e-Shoora (Parliament) to make law." ${ }^{, 78}$ Presidential ordinances, as per the Constitutional provisions, stand expired after 120 days from their promulgation or before if a resolution is passed in the Assembly to disapprove them. A presidential ordinance can only be extended once for another period of 120 days and only through a resolution of the national assembly. $^{79}$

\subsection{3: THE JUDICIARY}

Particularly in developmental activities in Pakistan, write Yasmeen and Ali "the judicial arm of a State not only acts as an arbiter between the State and the citizens but also acts as a watchdog over the acts of the legislature and the executive." ${ }^{\prime \prime 0}$ The Constitution of Pakistan provides the Supreme Court of Pakistan original, appellate and advisory jurisdictions. The original jurisdiction of the Supreme Court of Pakistan is in any dispute between two or more governments and importantly also on "question of public importance with reference to the enforcement of any of the Fundamental Rights," which gives the higher judiciary far reaching

\footnotetext{
${ }_{78}^{78}$ Clause 1 and 2, Article 89, the 1973 Constitution of Pakistan

${ }^{79}$ Clause 2, Article 89, the 1973 Constitution of Pakistan

${ }^{80}$ Yasmeen, S. and Ali, W., "Role and Functions of Judicial System in Pakistan," Science,

Technology and Development, Vol. 30, No. 3 (2011): 1
} 
powers in terms of formulation of public policies in Pakistan on matters of 'public-interest' ${ }^{81}$ The Article 190 further states that "All executive and judicial authorities throughout Pakistan shall act in aid of the Supreme Court." ${ }^{82}$ Bashir observes, "the judiciary in Pakistan was not historically a key player in the public policy processes. However, around the mid-2000s, the Supreme Court of Pakistan started taking a closer look into matters of policy and started intervening when irregularities were found. ${ }^{, 83}$ Referring to the same original jurisdiction of the Supreme Court under the Article 184 of the Constitution of Pakistan and its application, Munir argues that "the turn of the Supreme Court towards a regime of judicial activism was due to its own understanding that it can go beyond the rules if circumstances so justify to safeguard the interests of the citizens in a constitutional scheme of things." ${ }^{84}$ Kalhan makes similar assertion that Pakistan's higher judiciary, in last few years, "have come to understand their roles and professional identities as being defined and legitimated directly by the Pakistani people [and] began to expand its use of public interest litigation and suo motu powers." ${ }^{, 85}$ Waseem agrees that especially in last few years "public interest litigation became the legal mechanism for the Supreme Court's populist stance." ${ }^{\prime 86}$ The 1973 Constitution of Pakistan provides the senior judiciary of original, review and appellate jurisdiction. Initially, the Supreme Court of Pakistan had restricted its review jurisdiction to interpretation of constitutional matters but lately it has penetrated to all domains of public life and relying more on its 'original jurisdiction'. Nonetheless, as Waseem argues that these jurisdictions allow senior judiciary to hold other organs of the state accountable for not only their acts of

\footnotetext{
${ }^{81}$ Clause 1 and 3, Article 184, the 1973 Constitution of Pakistan

${ }^{82}$ Article 190, the 1973 Constitution of Pakistan

${ }^{83}$ Bashir, M., 2013: 401; a brief historical account of judicial independence in Pakistan is provided by: Habib, R. Imran and Zahraa, M., "Judicial Independence in Pakistan: A Brief Historical Account," Harvard Asia Quarterly, Vol. XIV, No. 2 (2012): 25 - 32

${ }^{84}$ Munir, Muhammad A., Public Interest Litigation in Supreme Court of Pakistan (2007): 66, retrieved from SSRN: http://ssrn.com/abstract=1984583 or http://dx.doi.org/10.2139/ssrn.198458366

${ }^{85}$ Kalhan, A." "“"Gray Zone” Constitutionalism and the Dilemma of Judicial Independence in Pakistan," Vanderbilt Journal of Transitional Law, Vol. 46, No. 1 (2013): 88

${ }^{86}$ Waseem, M., "Judging Democracy in Pakistan: Conflict Between the Executive and Judiciary," Contemporary South Asia, Vol. 20, No. 1 (2012): 27
} 
commission but also omission and in the process courts virtually assume the function of governance. $^{87}$

The next section provides a brief resume of the Thirteenth National Assembly of Pakistan in terms of legislative public policy making. The Thirteenth National Assembly has a distinct place in the political history of Pakistan. Starting its term on March 17, 2008, it is the first democratically elected government, under the civilian leadership, which not only completed its five-year constitutional tenure but also handed over power to another popularly elected leadership. In the context of Pakistan, for the first time the Thirteenth National Assembly allows analysis of legislative public policies over a complete duration of a popularly elected government.

\section{6: LEGISLATIVE PUBLIC POLICES UNDER THE THIRTEENTH NATIONAL ASSEMBLY OF PAKISTAN}

Pakistan's latest bid to return to the transition path to democracy came with the general elections held on February 18, 2008. Though still the President of Pakistan by the time the 2008 elections were held - General Pervez Musharraf had lost considerable clout in the backdrop of widespread political instability and with his forced resignation as the army chief in November 2007. The political party - Pakistan Muslim League (Quaid) - which had supported General Musharraf throughout his military rule, lost majority as the result of the elections in the national as well as provincial assemblies. With rival political factions in power, Pakistan Peoples Party at the Centre and Pakistan Muslim League (Nawaz) in the largest province of Punjab, General Musharraf was threatened with the impeachment. Under

${ }^{87}$ Ibid, 28 
immense political pressure, General Musharraf reluctantly resigned on August 18, 2008 as the President of Pakistan and the country once more fully returned to a popularly elected civilian government. The Government installed as the result of February 18, 2008 general election, started its constitutional tenure on March 17, 2008 and completed it on March 16, 2013.

A scorecard developed by Pakistan Institute of Legislative Development and Transparency, a non-profit institution working for strengthening of democracy in the country, to evaluate performance of the Thirteenth National Assembly found its involvement in foreign policy and self-accountability to have scored the least among other qualifiers. ${ }^{88}$ In terms of legislative capacity, not only the Thirteenth National Assembly scored the highest but also its legislative performance improved with the passage of time during its five-year tenure. Interestingly, with the qualifier of National Assembly's legislative capacity, adequateness of opportunities for individual members to introduce draft legislation scored the highest while systems and transparency in procedure for consultation with relevant groups and interests in the course of legislation scored the least. ${ }^{89}$ Overall, there were 222 government bills and ordinances and 205 private members' bills were introduced during the five-year tenure of the Thirteenth National Assembly of Pakistan. Of these, 120 government and 19 private members' bills were passed and became acts of the parliament (see table 5.6 on the legislative performance of the five years of the Thirteenths National Assembly of Pakistan). During the five-year tenure of the Thirteenth National Assembly of Pakistan, only six legislations were passed pertaining to social issues - four on rights of women and one each on education and health. Furthermore, only three legislations were made part of the national

\footnotetext{
${ }^{88}$ Pakistan Institute of Legislative Development and Transparency, Score Card: 5 Years of the 13th National Assembly of Pakistan (Islamabad: PILDAT, 2013)

${ }^{89}$ Ibid, 21
} 
gazette as separate acts of the parliament while the other three brought amendments into the Pakistan Penal Code. ${ }^{90}$ Of the six legislations passed, two are on prevention of sexual harassment. The first one was passed in 2010 as Criminal Law (Amendment) Act, 2010 which made amendments in Section 509 of the Pakistan Penal Code and made sexual harassment at the premises of workplace or outside workplace in relations to employment punishable by three year imprisonment or fine of up to five hundred thousand rupees or both. The second law came as a separate act, the Protection against Harassment of Women at the Workplace Act, 2010, bringing legal safety nets for the protection of workingwomen and making employers mandatory to appoint ombudspersons at different levels. The other two pro-women bills passed were initiated as Acid Control and Burn Crime Prevention Bill and Protection of Anti Women Practices Bill which became acts of parliament in 2011 as Criminal Law (Second Amendment) Act, 2011 and Criminal Law (Third Amendment) Act 2011 respectively. The remaining two social bills relate to access to education and transplantation of human organs and passed as the Right to Free and Compulsory Education Act, 2012 and the Transplantation of Human Organs and Tissues Act, 2010. These two acts together with the Protection against Harassment of Women at the Workplace Act 2010 are studied for the purpose of this research.

\section{7: CONCLUDING WORDS}

In this chapter, only those organs of the State are studied that have the formal authority of formulating public policies in Pakistan. However, which is also one of the premises of this research, public policy making is far more complex and multi-layered than any formal institutional arrangement that could be broken into stage-heuristic models. For instance,

\footnotetext{
${ }^{90}$ The provisions related to all offences charged in Pakistan are contained in the Pakistan Penal Code.
} 
Imam and Dar have devoted an entire book that investigates the role of Pakistan's grassroots public administration structures and their quasi-legislative and quasi-judicial duties in supporting democracy in the country. ${ }^{91}$ Bashir also considers civil bureaucracy as one of the key players in public policy processes in Pakistan and argues, "The influence of the civil bureaucracy has continued ever since the matters of public policy as well as other matters such as the operations of non-profits, the functions of political government entities and public works. ${ }^{, 92}$ In addition to civil bureaucracy, Bashir also discusses in some length the role of religious institutions, military, international financial agencies and foreign governments in public policy making in Pakistan. ${ }^{93}$ Arguing on similar lines, Kalia writes that "Among countless factors that come into play [in public policy process in Pakistan]; the most dominant ones are the; structure and evolution of bureaucracy, impact of governing regime and vested interests of the players involved." ${ }^{94}$ Ayesha Khan, in her article, has studied policy making in Pakistan's population programme and how it is shaped by political consideration of the political consideration of the various military and civilian regimes, the role of religion in politics, the influences of Westerns donors and the effect of international development ideology. ${ }^{95}$ Ali, in his prescriptive analysis of policy outcomes in education sector, argues that it is important to understand the perception of agents to diagnose the reasons of policy failures in Pakistan. ${ }^{96}$ Within the ambit of new institutionalism, Ali considers not just the formal institutional environment that consist of governance structures, centralisation, commitment of political leadership and availability of resources, among other factors, but

\footnotetext{
${ }^{91}$ Imam, A. and Dar, E. A., Democracy and Public Administration in Pakistan (Boca Raton: CRC Press, 2014)

${ }^{92}$ Bashir, M., 2013: 399

${ }^{93}$ Ibid, $396-407$

${ }^{94}$ Kalia, S., "Bureaucratic Policy Making in Pakistan," The Dialogue, Vol. 8, No. 2 (2013): 157

${ }^{95}$ Khan, A., "Policy-making in Pakistan's Population Programme," Health Policy and Planning, Vol. 11, No. 1 (1996): $30-51$

${ }^{96}$ Ali, S., "Why does Policy Fails? Understanding the Problems of Policy Implementation in Pakistan - Neuro-Cognitive Perspective," International Studies In Educational Administration, Vol. 34, No. 1 (2006): 16
} 
logic of appropriateness, path dependency and value justification to be also serving as constraints on policy makers. ${ }^{97}$ For a policy analyst then it becomes essential to extend theoretical and empirical work to combine much more of the interdependences and multidimensionality of public policy for improved understanding. ${ }^{98}$ The aim of this research is also to look beyond formal institutional arrangements and explore in greater detail the interdependencies and multidimensionality in public policy making and its outcomes by taking the case of Pakistan.

After having presented the formal process of public policy making in Pakistan, the next Chapter discuses the role of interest groups in public policy making and their influence on the political development and democratization in Pakistan using the Thirteenth National Assembly once more as the reference period.

\footnotetext{
${ }^{97}$ Ibid

${ }^{98}$ Sproule-Jones, M., "Multiple Rules and the 'Nesting' of Public Polices," Journal of Theoretical Politics, Vol. 1, No. 4 (1989): 476
} 


\begin{tabular}{|c|c|c|c|c|c|c|c|c|}
\hline \multicolumn{9}{|c|}{$\begin{array}{l}\text { Table 5.1: } \\
\text { Administrative Units of Pakistan }\end{array}$} \\
\hline \multirow[t]{2}{*}{ Provinces / Regions } & \multirow[t]{2}{*}{ Divisions } & \multirow[t]{2}{*}{ District } & \multirow{2}{*}{$\begin{array}{c}\text { Sub- } \\
\text { Districts }\end{array}$} & \multirow[t]{2}{*}{$U C$} & \multicolumn{4}{|c|}{ Total Urban Area } \\
\hline & & & & & $\begin{array}{l}\text { Muni. } \\
\text { Corp. }\end{array}$ & $\begin{array}{l}\text { Muni } \\
\text { Comm. }\end{array}$ & $\begin{array}{l}\text { Town } \\
\text { Comm. }\end{array}$ & Cant. \\
\hline Balochistan & 6 & 30 & 132 & 506 & 4 & 54 & 28 & 4 \\
\hline $\begin{array}{l}\text { Khyber } \\
\text { Pakhtunkhwa }\end{array}$ & 7 & 25 & 67 & 957 & - & 30 & 13 & 11 \\
\hline Punjab & 9 & 36 & 137 & 3,466 & 8 & 72 & 146 & 20 \\
\hline Sindh & - & 23 & 103 & 1,088 & 3 & 31 & 115 & 8 \\
\hline $\begin{array}{l}\text { Islamabad Capital } \\
\text { Territory }\end{array}$ & - & 1 & 1 & 46 & - & 1 & - & - \\
\hline $\begin{array}{l}\text { Federally } \\
\text { Administered } \\
\text { Tribal Territories }\end{array}$ & - & 7 & 42 & - & - & 14 & - & - \\
\hline $\begin{array}{l}\text { Azad Jammu \& } \\
\text { Kashmir }\end{array}$ & 3 & 10 & 30 & - & - & 11 & 7 & - \\
\hline Gilgit Baltistan & 2 & 7 & 21 & - & - & 5 & - & - \\
\hline Total & 27 & 139 & 533 & 6,055 & 11 & 178 & 309 & 43 \\
\hline
\end{tabular}

${ }^{99}$ Pakistan Bureau of Statistics, Agriculture Statistics of Pakistan 2010 - 2011 (Islamabad: Statistics Division, 2013): Table 175 


\begin{tabular}{|l|r|r|r|r|r|r|r|}
\hline $\begin{array}{l}\text { Table 5.2: } \\
\text { Total Number of Seats in the National and Provincial Assemblies of Pakistan by Provinces and } \\
\text { Regions }\end{array}$ \\
\hline Provinces / Regions & \multicolumn{3}{|c|}{ National } & \multicolumn{5}{c|}{ Provincial } \\
\cline { 2 - 9 } & General & Women & Total & General & Women & Non-Muslims & Total \\
\hline Balochistan & 14 & 3 & 17 & 51 & 11 & 3 & 65 \\
\hline Khyber Pakhtunkhwa & 35 & 8 & 43 & 99 & 22 & 3 & 124 \\
\hline Punjab & 148 & 35 & 183 & 297 & 66 & 8 & 371 \\
\hline Sindh & 61 & 14 & 75 & 130 & 29 & 9 & 168 \\
\hline FATA & 12 & - & 12 & - & - & - & - \\
\hline Federal Capital & 2 & - & 2 & - & - & - \\
\hline Total & 272 & 60 & $332 *$ & 577 & 128 & 728 \\
\hline *In addition, 10 seats are reserved for the whole of Pakistan for Non-Muslims in the National \\
Assembly
\end{tabular}


Table 5.3:

Comparison of Provincial Local Government Acts by Provinces

\begin{tabular}{|c|c|c|c|c|}
\hline $\begin{array}{l}\text { Provincial } \\
\text { Local } \\
\text { Government } \\
\text { Acts }\end{array}$ & $\begin{array}{l}\text { Tiers of the Local } \\
\text { Government System in } \\
\text { Provinces }\end{array}$ & Elections & $\begin{array}{l}\text { Term } \\
\text { of } \\
\text { Office }\end{array}$ & Key Functions \\
\hline $\begin{array}{l}\text { Punjab Local } \\
\text { Government } \\
\text { Act } 2013\end{array}$ & $\begin{array}{l}\text { Metropolitan Corporations in } \\
\text { provincial capital; District } \\
\text { Councils in rural areas; } \\
\text { Municipal Corporations and } \\
\text { Municipal Committees; } \\
\text { Union Councils (UC) for } \\
\text { both urban and rural areas } \\
\text { (except for the provincial } \\
\text { capital); All councils led by } \\
\text { Chairman/Vice Chairman }\end{array}$ & $\begin{array}{l}\text { Party based } \\
\text { elections at all tiers } \\
\text { and direct election at } \\
\text { Union Council level }\end{array}$ & 5 year & $\begin{array}{l}\text { Municipal } \\
\text { functions of health } \\
\text { and education } \\
\text { under indirectly } \\
\text { elected members } \\
\text { and technocrats }\end{array}$ \\
\hline $\begin{array}{l}\text { Sindh Local } \\
\text { Government } \\
\text { Act } 2013\end{array}$ & $\begin{array}{l}\text { Metropolitan Corporations in } \\
\text { urban areas; District } \\
\text { Councils in rural areas; } \\
\text { Municipal Corporations and } \\
\text { Municipal Committees; } \\
\text { Union Councils for both } \\
\text { urban and rural areas; All } \\
\text { councils led by Chairman } \\
\text { and Vice Chairman }\end{array}$ & $\begin{array}{l}\text { Party-based and } \\
\text { indirect elections at } \\
\text { all tiers; }\end{array}$ & 4 year & $\begin{array}{l}\text { LGs Council } \\
\text { municipal } \\
\text { mandate include } \\
\text { functions of water, } \\
\text { health, education, } \\
\text { and town planning }\end{array}$ \\
\hline $\begin{array}{l}\text { Khyber } \\
\text { Pakhtunkhwa } \\
\text { Local } \\
\text { Government } \\
\text { Act } 2013\end{array}$ & $\begin{array}{l}\text { City Districts Councils; } \\
\text { Districts Councils; Sub- } \\
\text { District/Towns Councils; } \\
\text { Village and Neighbourhood } \\
\text { Councils (VNC) for rural } \\
\text { areas and urban areas; the } \\
\text { tier of Unions has been } \\
\text { omitted in the Act; all } \\
\text { councils led by Mayor and } \\
\text { Deputy Mayor }\end{array}$ & $\begin{array}{l}\text { Non-party based for } \\
\text { VNC; party-based } \\
\text { elections for Sub- } \\
\text { District and District } \\
\text { Councils; direct } \\
\text { election at VNC } \\
\text { levels; indirect } \\
\text { election at District } \\
\text { and Sub-District } \\
\text { tiers }\end{array}$ & 4 year & $\begin{array}{l}\text { LGs Council } \\
\text { municipal } \\
\text { mandate include } \\
\text { functions of } \\
\text { health, education, } \\
\text { social welfare, } \\
\text { revenue and } \\
\text { estate, rural } \\
\text { development }\end{array}$ \\
\hline
\end{tabular}




\begin{tabular}{|c|c|c|c|c|}
\hline \multicolumn{5}{|c|}{$\begin{array}{l}\text { Table 5.3: } \\
\text { Comparison of Provincial Local Government Acts by Provinces }\end{array}$} \\
\hline $\begin{array}{l}\text { Provincial } \\
\text { Local } \\
\text { Government } \\
\text { Acts }\end{array}$ & $\begin{array}{l}\text { Tiers of the Local } \\
\text { Government System in } \\
\text { Provinces }\end{array}$ & Elections & $\begin{array}{l}\text { Term } \\
\text { of } \\
\text { Office }\end{array}$ & Key Functions \\
\hline $\begin{array}{l}\text { Balochistan } \\
\text { Local } \\
\text { Government } \\
\text { (Amendment) } \\
\text { Act No. V } 2011\end{array}$ & $\begin{array}{l}\text { Metropolitan Corporations in } \\
\text { urban areas; District } \\
\text { Councils in rural areas; } \\
\text { Municipal Corporations and } \\
\text { Municipal Committees; } \\
\text { Union Councils for both } \\
\text { urban and rural areas; all } \\
\text { councils led by Chairman } \\
\text { and Vice Chairman }\end{array}$ & $\begin{array}{l}\text { Party based } \\
\text { elections at all tiers; } \\
\text { as per procedure to } \\
\text { be prescribed by the } \\
\text { Provincial } \\
\text { Government }\end{array}$ & 4 year & $\begin{array}{l}\text { LGs Council } \\
\text { municipal } \\
\text { mandate include } \\
\text { functions of } \\
\text { health, education, } \\
\text { town planning, } \\
\text { public safety. }\end{array}$ \\
\hline \multicolumn{5}{|c|}{$\begin{array}{l}\text { Adapted from: Devolution Trust for Community Empowerment, Local Government Watch, Edition 1, } \\
\text { as per the status on January 31, } 2014\end{array}$} \\
\hline
\end{tabular}




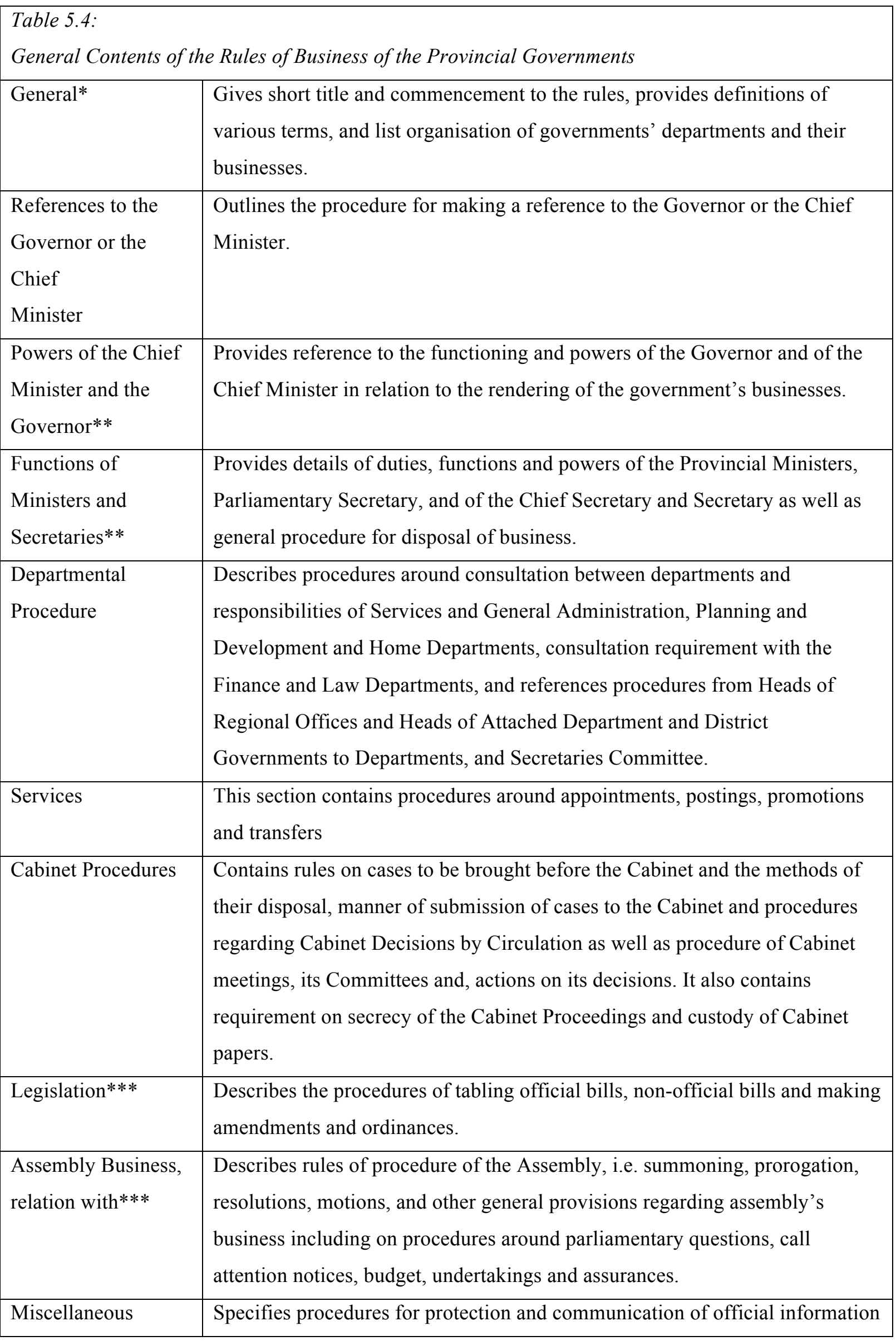


Table 5.4:

General Contents of the Rules of Business of the Provincial Governments

\begin{tabular}{l|l} 
Provisions & and channel of correspondence as well as references to any amendment made
\end{tabular} to the Rules and repeal.

*In Balochistan Government Rules of Business 2012, power of Chief Minister is delineated within the General Section.

** In Sindh Government Rules of Business 1986, separate sections are devoted to describing powers of the Chief Minister and Governor as well as for the functions of ministers and secretaries *** In Rules of Business 1985 of Khyber Pakhtunkhwa provincial government, legislation and assembly's business is covered under "Relations with the Provincial Legislature." 


\begin{tabular}{|c|c|c|c|c|}
\hline \multicolumn{5}{|c|}{$\begin{array}{l}\text { xTable 5.5: } \\
\text { A Process of Legislative Law Making in Pakistan (Non-money bills) }{ }^{100}\end{array}$} \\
\hline Stages & \multicolumn{4}{|l|}{ Procedures } \\
\hline Introduction & \multicolumn{2}{|c|}{$\begin{array}{l}\text { Private Bill: A bill moved by a } \\
\text { parliamentarian }\end{array}$} & \multicolumn{2}{|c|}{$\begin{array}{l}\text { Government Bill: A bill introduced by } \\
\text { the Government }\end{array}$} \\
\hline Publication & \multicolumn{4}{|c|}{$\begin{array}{l}\text { The Secretary of the Assembly publishes the proposed bill, together with statement of } \\
\text { objects and reasons, before its introduction, in the Gazette }\end{array}$} \\
\hline \multirow[t]{10}{*}{ Consideration } & \multicolumn{2}{|c|}{$\begin{array}{l}\text { Report by the Standing Committee as } \\
\text { favourable (with/without amendments), } \\
\text { unfavourable or without opinion }\end{array}$} & \multicolumn{2}{|c|}{$\begin{array}{l}\text { Upon motion, Speaker/Chairman ask } \\
\text { consideration of the bill without } \\
\text { referring it to the concerned standing } \\
\text { committee }\end{array}$} \\
\hline & \multicolumn{4}{|c|}{$\begin{array}{l}\text { Bill is put on the list of the business for a day meant for government business or for } \\
\text { the private members' business }\end{array}$} \\
\hline & \multicolumn{4}{|c|}{ Motion for the consideration of the bill by the "member-in-charge" } \\
\hline & $\begin{array}{l}\text { Consideration at } \\
\text { once }\end{array}$ & $\begin{array}{l}\text { Consideration on a } \\
\text { date to be fixed }\end{array}$ & \multirow{2}{*}{$\begin{array}{l}\text { Referred back } \\
\text { to the Select } \\
\text { Committee }\end{array}$} & \multirow[t]{2}{*}{$\begin{array}{l}\text { Circulated further for } \\
\text { eliciting opinion }\end{array}$} \\
\hline & \multicolumn{2}{|c|}{$\begin{array}{l}\text { First Reading: principles and general } \\
\text { provisions }\end{array}$} & & \\
\hline & $\begin{array}{l}\text { Refer back to the } \\
\text { Select Committee }\end{array}$ & \multicolumn{2}{|c|}{ Circulate further for eliciting opinion } & \\
\hline & \multicolumn{4}{|c|}{$\begin{array}{l}\text { Bill is moved again as reported by the Select Committee, or referred to the same } \\
\text { Committee again as a whole, for consideration }\end{array}$} \\
\hline & \multicolumn{4}{|c|}{ Second Reading: Consideration of the bill clause-by-clause } \\
\hline & \multicolumn{4}{|c|}{$\begin{array}{l}\text { Once the bill is considered clause-by-clause, the member-in-charge moves the motion } \\
\text { for the passage of the bill. }\end{array}$} \\
\hline & \multicolumn{4}{|c|}{$\begin{array}{l}\text { The general provisions may once again be discussed before the passage, but only in } \\
\text { reference to the amendment, if any, made in the bill. }\end{array}$} \\
\hline \multirow[t]{3}{*}{ Passage } & \multirow{3}{*}{\multicolumn{2}{|c|}{$\begin{array}{l}\text { Bill is passed in the Provincial Assembly } \\
\text { and }\end{array}$}} & \multicolumn{2}{|c|}{$\begin{array}{l}\text { Bill passed in one house of the National } \\
\text { Parliament and transmitted to the other } \\
\text { house for consideration. }\end{array}$} \\
\hline & & & \multirow{2}{*}{$\begin{array}{l}\text { Other house } \\
\text { also passes the } \\
\text { bill }\end{array}$} & $\begin{array}{l}\text { Bill is not passed, } \\
\text { rejected or amended }\end{array}$ \\
\hline & & & & Bill is presented in the \\
\hline
\end{tabular}

${ }^{100}$ Adapted from: Consumer Rights Commission of Pakistan, The Process of Law Making (Islamabad: Al-Rehman Printers, 2005) 


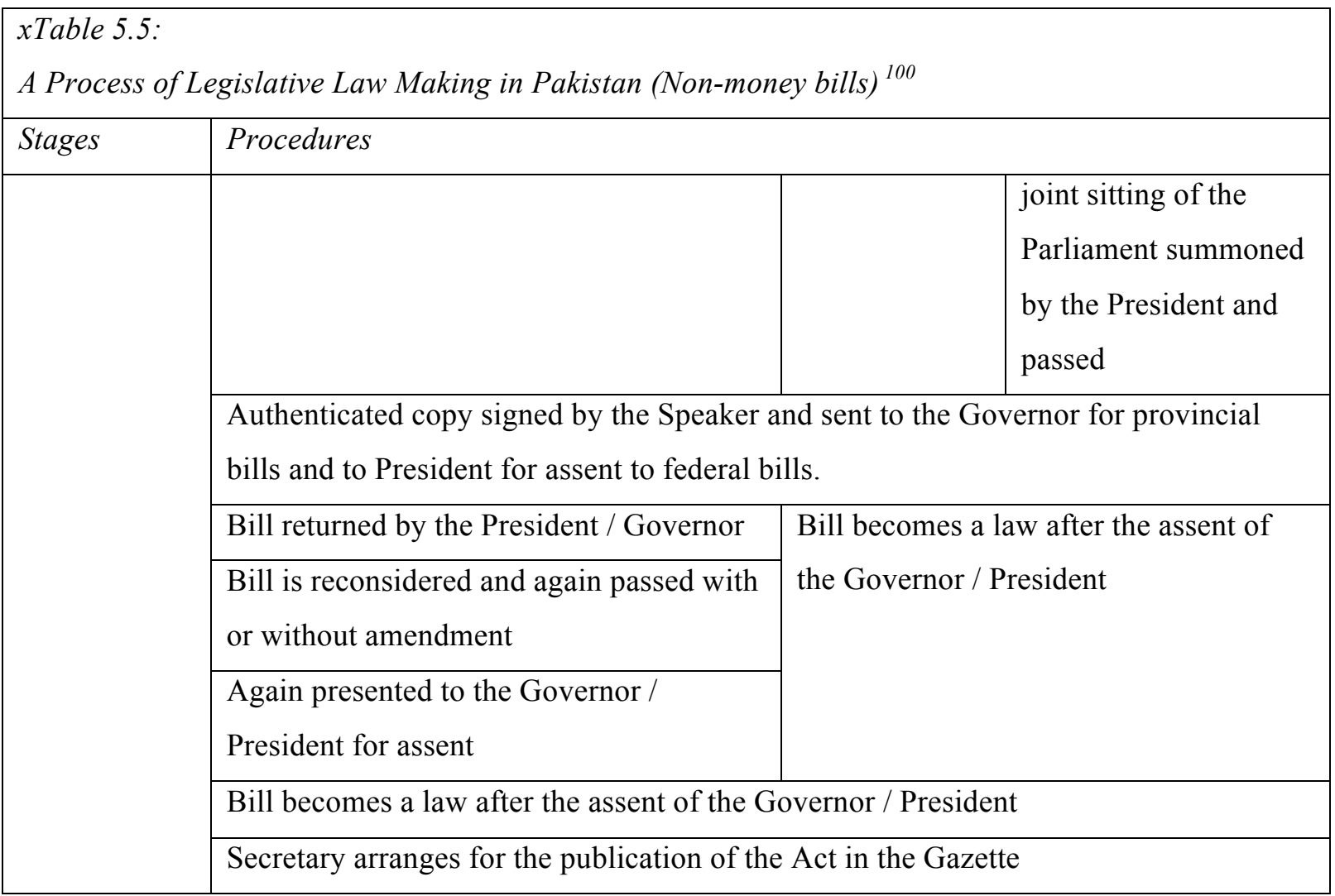




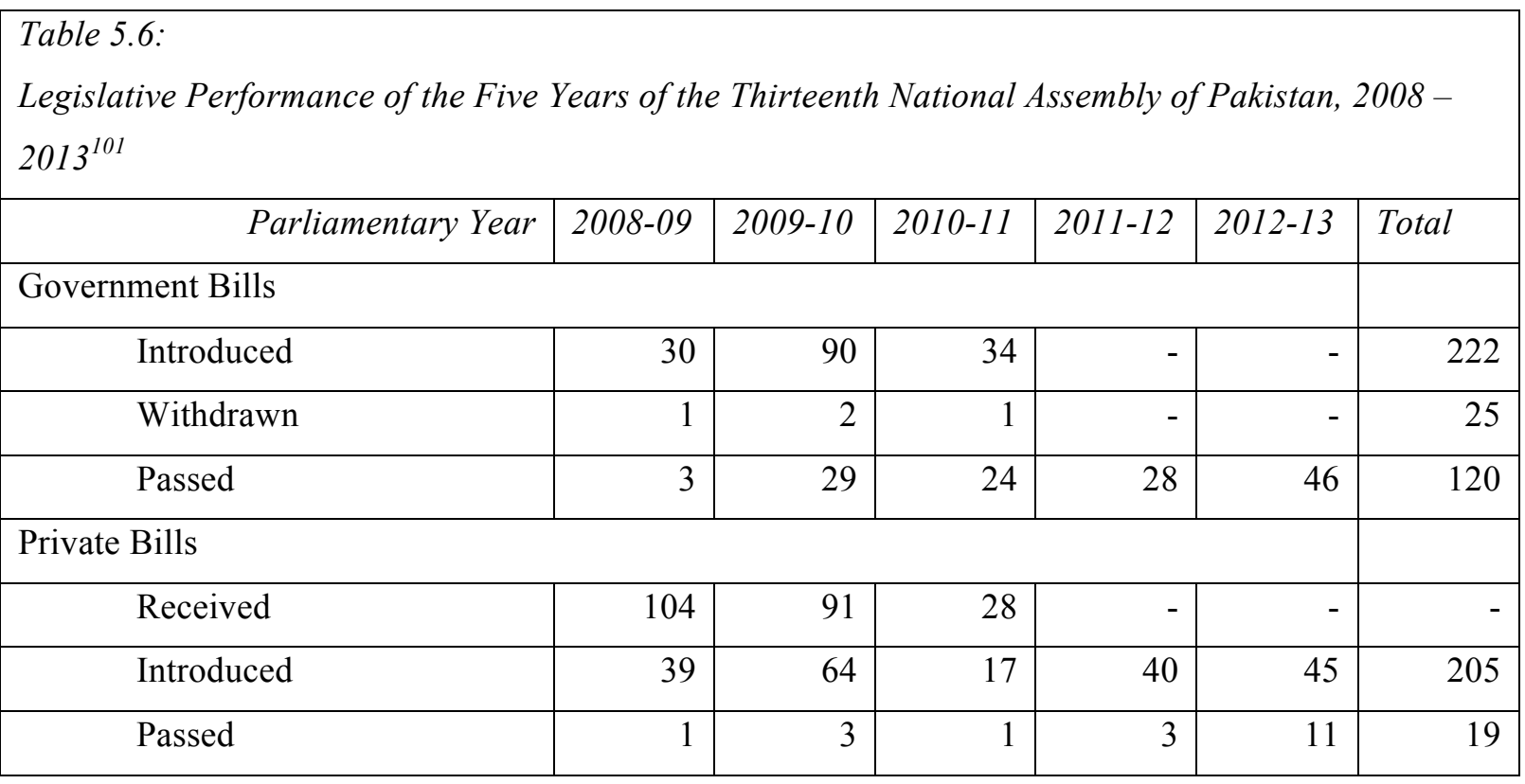

${ }^{101}$ Pakistan Institute of Legislative Development and Transparency, Citizens Report: 5 Years of the $13^{\text {th }}$ National Assembly of Pakistan (Islamabad: PILDAT, 2013): 29 


\section{CONTESTATION AND INCLUSIVENESS IN PUBLIC}

\section{POLICY MAKING IN PAKISTAN}

\section{1: INTRODUCTION}

Interest groups in pluralistic democracies occupy a key position. They aggregate private interests and represent them in public policy and thereby mediate between society and the sate. ${ }^{1}$ It does not, however, imply that interest groups are a feature of democratised nations only. Interest groups are as much a feature of a totalitarian regime and of all those that fall somewhere on a broad spectrum of political extremities - countries in the grey-zone. What widely vary are the nature, extent and influence of interest groups on the political development in transitioning democracies. While volumes have been written on democracy transition and various factors that can either impede or facilitate this process, little attention is given on the role of interest group systems in struggling democracies of grey-zone. ${ }^{2}$ By struggling democracies those regimes are referred that have stalled somewhere in a political grey-zone on the transition path to democratic consolidation and are at risk of falling back in some form or another of an authoritarian state. In this Chapter, interest groups intermediation and their participation is assessed in selected cases of public policy for understanding the extent to which the public policy process is inclusive and contested as well as its impact on the process of democratisation in Pakistan. This chapter builds on the discussion of the previous chapter where formal institutions of policy making in Pakistan are discussed and

\footnotetext{
${ }^{1}$ Padgett, S., Organizing Democracy in Eastern Germany: Interest Groups in Post-Communist Society (Cambridge: Cambridge University Press, 2000): 1

${ }^{2}$ Thomas, Clive S. and Hrebenar, Ronald J., "Understanding Interest Groups, Lobbying and Lobbyists in Developing Democracies," Journal of Public Affairs, 8 (2008): 1
} 
leads to the core of this research to understand how ideas generate and impact policy outcomes in a political system broadly understood of consisting of inclusiveness and contestation.

Interest groups are broadly understood as groups of individuals and/or institutions joined together to protect or press shared interest by influencing public decision-making. ${ }^{3}$ The existing literature on democratic consolidation in transitioning countries generally talks of interest groups in the garb of 'civil society.' Civil society, as a concept, is broader and encompasses all the organisations and associations, including political parties, which exist outside the state. Interest groups, however, are distinctive in their purpose within the wider network of civil society organisations and are created to advance specific social, political and material agendas of public decision-making. ${ }^{4}$ One of the determinants of the quality of democracy is open membership and participation in interest groups and formal or informal institutionalised channels of interest group intermediation. Conversely it implies, in the words of Grugel, a thin democracy where patterns of participation are low and the state has few obligations to listen to society. Any explanation for understanding the likely success or failure of the process of democratisation in struggling democracies must pay attention to the role of interest groups. ${ }^{5}$ In this paper, an analytical framework is developed, based on the two-dimensional classification of Dahl, and applied to the case of Pakistan for understanding the role of interest groups in public policy making and their influence on political development.

\footnotetext{
${ }^{3}$ Allern, Elin H. and Bale, T., "Political Parties and Interest Groups: Disentangling Complex Relationship," Party Politics, 18.1 (2012): 8

${ }^{4}$ Munger, Michael C., "Interest Groups 1," in Charles K. Rowley and Friedrich Schneider (eds.) The Encyclopaedia of Public Policy, Vol. 1 (New York: Kluwer Academic Publishes, 2004): 308

${ }^{5}$ Grugel, J., Democratization: a Critical Introduction (New York: Palgrave, 2002): 115
} 
Pakistan typifies the case of a struggling democracy. The elected government in 2008 is the first in country's history to have remained in office long enough to complete its constitutional tenure of five years and handing over power to an elected successor in 2013. Is it, however, a strong enough indication that the country is on the path towards democratic consolidation? It is contended that in order to bring political stability and strengthen democratic transition in Pakistan, interest groups intermediation in public policy needs to be institutionalised. In absence of such formalised mechanisms, persistent populist manifestation of interests weakens, and could even reverse, the democratic transition. In the next section, the theory of interest groups and state-centred theories are briefly revisited in this context. In light of these two theories, Section 3 discusses interest groups intermediation and their participation in public policy making and presents the main contours of the analytical framework. In Section 4, the framework is applied to the case of Pakistan. Based on the analysis, some conclusions are drawn on the prospects of democracy in Pakistan in the final section.

\section{2: INTEREST GROUPS AND THEORIES OF THE STATE}

One of the main channels of interest articulation and representation in modern democratic societies is interest groups operating independent of political parties. ${ }^{6}$ In struggling democracies, political parties often become captive of autocratic personalities or function as tools of entrenched special interests and only occasionally represent the views of broad-based constituencies. ${ }^{7}$ Large sections of the citizenry in struggling democracies feel that their political system is unresponsive to their needs as political parties fail to create linkages with

\footnotetext{
${ }^{6}$ Bartolini, S. and Mair, S., "Challenges to Contemporary Political Parties," in Larry Diamond and Richard Gunther (eds.) Political Parties and Democracy (Baltimore: The Johns Hopkins University Press, 2001): 334

${ }^{7}$ Brinkerhoff, Derick W., Governance in Post-Conflict Societies: Rebuilding Fragile States (New York: Routledge, 2007): 66
} 
vthe citizens beyond the appeal for votes every few years when election takes place. ${ }^{8}$ This poses a serious challenge for democratisation in struggling democracies. In view of weak state of political parties, the emergence of interest group politics in struggling democracies has been described as one of the decisive issues of democratic transformation. ${ }^{9}$ Analysis of the conditions of democratic consolidation has revealed that positive evolution of opinions and attitudes about democracy in part depends on institutional reforms that allow deepening of the representation and participation of different interest groups within political system. ${ }^{10}$ Yet, this remains an undertheorized area. ${ }^{11}$ In absence of a theoretical framework for struggling democracies, existing theories would have to be contextualised and adapted for understanding interest group systems and their influence on political development.

The theory of interest groups contributes to our understanding of how individuals are related in politics in addition to their intermittent role as voters. ${ }^{12}$ The theory essentially stipulates that government policies, in pluralistic societies, are the results of a complex interplay of contending interest groups inside or outside the government that exert influence on public policy process to gain favourable outcomes. ${ }^{13}$ Neopluralists have broadened the traditional conception of pluralism by emphasising not only on plurality of groups but also on specific kind of groups divided on communal lines such as on ethnicity, religion, language or race. An alternative understanding of democracy, stemming in part as a critique of pluralism, is

\footnotetext{
${ }^{8}$ Carothers, T., "Political Party Aid: Issues for Reflection and Discussion," in Helena Bjuremalm (ed.) Supporting Political Party Systems: Experiences and Challenges (Stockholm: Swedish International Development Cooperation Agency, 2005): 11

${ }^{9}$ Padgett, S., Organizing Democracy in Eastern Germany: Interest Groups in Post Communist Society (Cambridge: Cambridge University Press, 2000): 1

${ }^{10}$ Ethier, D., "Democratic Consolidation," in Abdo I. Baaklini and Helen Desfosses (eds.) Designs for Democratic Stability: Studies in Viable Constitutionalism (New York: M. E. Sharpe, Inc., 1997): 261

${ }^{11}$ Thomas, Clive S. and Hrebenar, Ronald J., 2008: 2

${ }^{12}$ Garceau, O., "Interest Group Theory in Political Research," Annals of the American Academy of Political and Social Science, 139 (1958): 104

${ }^{13}$ Gable, Richard W., "Interest Groups as Policy Shapers," Annals of the American Academy of Political and Social Science, 139 (1958): 85
} 
labelled as neocorporatism. Essentially, in neocorporatist system of policymaking and interest-group intermediation, a small number of concerned groups and associations, also called "peak associations," enter into formal relationship with the state to negotiate outcomes. ${ }^{14}$ At the opposite spectrum is the elitist conception in which democracy at best entails competitive and participatory elections among a privileged class of people, by virtue of their resources and positions in the society. In its contemporary understanding, according to Best and Higley "policy packages are constructed and presented by leaders and coteries of advisors," which essentially makes public policy making an exercise of power by elite over non-elites. ${ }^{15}$ In the words of Mills, power elite refers to those "political, economic and military circles," that have accumulated considerable prestige above the ordinary. ${ }^{16}$ In Marxist literature, a parallel concept is of democratic centralism referring to a political decision-making system based on the organisation of a Leninist party where lower bodies elect higher organs of the state and participate in making decision from bottom-up. ${ }^{17}$ Aspects of intermediation with interest groups and their participation in public policy connects statecentred theories on a broad spectrum that stretches from political pluralism on the one end to elitism on the other. In the next Section, policymaking is discussed in light of these theories to develop a better understanding of the nature, extent and influence of interest groups on the political development and the likely success or failure of the process of democratisation in struggling democracies.

\footnotetext{
${ }^{14}$ Hrebenar, Ronald J. and Morgan, Bryson B., Lobbying in America: A Reference Handbook (Santa Barbara: ABC-CLIO Inc., 2009): 84

${ }^{15}$ Best, H. and Higley, J., Democratic Elitism: New Theoretical and Comparative Perspectives (Boston, MA: Brill Academic Publishers, 2010): 9

${ }^{16}$ Mills, C. W., The Power Elite, new edition (Oxford: Oxford University Press, 2000): 18 \& 83

${ }^{17}$ Kenez, P., A History of the Soviet Union from the Beginning to the End, second edition (Cambridge: Cambridge University Press, 2006): 51
} 


\section{3: INTEREST GROUPS INTERMEDIATION AND STATE-CENTRED THEORIES}

In its contemporary understanding, political pluralism is a competition, bargaining and compromise among numerous interest groups. Interest groups exist in each sector of the society to which individuals are free to join and participate for pressing demands on government for favourable public policy outcomes. Since power is highly dispersed, there is no dominant group and the end result is a compromise over key policy decisions through a complex bargaining and lobbying process. The public-policy making direction is upward from masses, represented by their interest groups, to elites that keep public-policy outcomes under check due to the balance of power. Importantly, the public policy outcome does not reflect the majority preference but is equilibrium of interest interaction and a reasonable approximation of society's preferences. ${ }^{18}$ In contrast, in the neocorporatist system of intermediation the interest groups enter into a formal bargaining relationship with the state to negotiate final policy outcomes. This system limits the number of interest claims made on the state which grants monopoly to certain peak groups that represent a broad cross-section of sectoral interests in exchange for their participation and cooperation in developing, and even implementing, public policy outcomes. Neocorporatism differs from pluralism, thus, on both structural and functional lines with the former enjoying representational monopoly and incentives by the state in exchange of cooperation in policy development as opposed to free competition yielding a compromised outcome in the latter.

In elitism, competition for influencing public agenda and decision-making is among only a small number of institutional leaders who hold power and money. Public policy reflects elites' preferences and, usually, changes incrementally overtime either when interests are

\footnotetext{
${ }^{18}$ Dye, Thomas R., Zeigler H. and Schubert, L., The Irony of Democracy: An Uncommon Introduction to American Politics, fifteenth ed. (Boston, MA: Wadsworth, Cengage Learning, 2012)
} 
redefined or policy-making is conceded to another elitist group. In its contemporary understanding, elitism is conflict, accommodation and circulation among elites over power concentration to affect political and policy outcomes. Moreover, in an elitist setting, a democratic regime merely serves as an institutional arrangement in which elites compete for voters' mandate to rule. Among the state-centred theories, the elite theory most closely resembles the political realities of a struggling democracy.

Struggling democracies usually have an authoritarian past and entrenched elites consisting of a handful of power groups from political, economic and military circles. These power groups dominate interest group activities either by having direct representation in the government or though their ability to influence governmental policies into their favour. This distinctive role and influence of interest groups in public policy making is the strongest defining characteristic of struggling democracies that set them aside from those regimes making progress towards democracy consolidation. Elite groups, once in power, consider public policy as their sole prerogative and see interests articulation as unwarranted and even unlawful. Policymaking becomes highly centralized with a downward flow and changes only incrementally. Interest group participation is restricted to groups to which power elites are directly associated or draw support from. Because power groups are the relics of an authoritarian past, they carry with them a number of legacies including imposing restrictions on interest groups formation and on their activities. They use intimidation, coercion and other undermining tactics including false propaganda and even banning such activities altogether to limit claim on their exercise of power.

Ruling elite is not without competition. Though limited in numbers, rival elite makes consistent claims on positions of power by carrying out subversive and manipulative 
measures to undermine, delegitimize and overthrow the ruling elite. Interest group intermediation, therefore, takes place only arbitrarily if public policies become highly unpopular or creates a sudden negative outburst from those affected by such policies. In such cases, policies are reverted and an acceptable solution is worked out. Interest group intermediation also takes place in cases where policies are either against the interests of rival elite or gives them the opportunity to gain political mileage. However for the ruling elite to succumb to reverting such policies, rival elite needs to rally popular support in their favour. During this competition, elite groups make repeated claims to adhering to the principles of democracy and frequent references to their democratic credentials. Use of state's machinery and other resources to propagate the same among the masses is a common practice (see Figure 6.1).

Figure 6.1 presents the analytical framework derived from the original work of Dahl and its refinement by Remmer for understanding the role of interest groups in policymaking in struggling democracies and its likely impact on a country's political development. ${ }^{19}$ Remmer's two-dimensional classification of regime type has 'inclusiveness' on one axis and 'competitiveness. The more the competitive and inclusive a regime is, the closer it will be, to what Remmer calls, 'Inclusionary Democracy' and the farther from the two will be 'Exclusionary Authoritarianism' In contrast, if the regime is tilted towards inclusiveness but lacks competitiveness represents 'Inclusionary Authoritarianism.' In contrast, if the regime is competitive but lacks inclusiveness is describes as 'Exclusionary Democracy. ${ }^{20}$ Remmer focuses on electioneering in her analysis on regime type but her framework can be extended

\footnotetext{
${ }^{19}$ See: Dahl, Robert A., Polyarchy: Participation and Opposition (New Heaven: Yale University Press, 1971); and Remmer, Karen L., "Exclusionary Democracy," Studies in Comparative International Development, Vol. 20, No. 4 (1985): 64 - 85

${ }^{20}$ ibid, p. 71
} 
analysis of interest group participation and their intermediation in public policy making in Pakistan.

By extending the seminal two-dimensional classification of regime type by Dahl and its extension by Remmer, public policy making is conceptualized to be a function of interest group participation on one hand and its intermediation on the other. When a regime enters on a transition path to democracy, from its authoritarian past, interest group participation is restricted in public policy making and intermediation exists only arbitrarily. Since elite groups dominate public policy arena, impetus is on formal institutionalisation of their power role on the premise of security and order. As a result, the push from the power elite is much on the lines of setting-up policy making structures that represent features of an authoritative democracy, i.e. restrictions on the media and civil society. ${ }^{21}$ On the other hand, since the semblance in the beginning is of a democratic regime in pursuit of liberal ideals, i.e. right of the freedom of association, certain concessions are made to partially free the media or letting associations and unions be formed, but only under the watchful eye of the ruling elite. This opens up the door for increased interest group activities in terms of new formations and those already existing further extending their network base. With the passage of time, interest group activities become stronger. New factions, movements and interest-based association are created outside the traditional elite structures that get mobilised if there is a sense of grievance and hostility towards the ruling elites. This creates tension between the populists asserting their interests and the elitists protecting their claim to power. Populism, as Bell argues, inherently implies pessimism about an elite's ability to make decisions for and protect

\footnotetext{
${ }^{21}$ Barber, Benjamin, R., Participatory Politics for a New Age (Barkley and Los Angeles: University of California Press, 2003): 140
} 
interests of the people affected. ${ }^{22}$ This leads to a constant struggle between the populists and the elitists to steer and press upon interest articulation between the two polls. The tension is released with the power being transferred to a rival elite group or the regime reverting to its authoritarian past. While the transition to a liberal democracy is never a linear progression, the strengthening of the public sphere is instrumental in subsiding violent populism and presenting people the potential to alter their own conditions of existence by means of rational-critical discourse. ${ }^{23}$ Conversely, such a transition may also generate counter publicspheres with a potential to originate new forms of fragmentation and solidarity and, as a result, endangering the process of democratisation. ${ }^{24}$ For a country's transition to democracy, it is essential that the impetus is both on opening up the membership and participation in organised interest groups. Side-by-side, it is no less important that the intermediation with interest groups is also institutionalised in forging public-policy outcomes, i.e. through formalised tripartite arrangements, i.e. establishing public forums, creating appellate bodies or giving formal membership in concerned regulatory bodies. Institutionalisation of intermediation with interest groups implies existence and nature of formal rules, as per the constitution, a specific law, or else in governmental and administrative provisions, that regulate political participation in public policy making of competing interests. ${ }^{25}$ In the next section, the proposed framework is applied to Pakistan with the help of brief recount of the political history as well as through three case studies selected form the tenure of the last government.

\footnotetext{
${ }^{22}$ Bell, J., Populism and Elitism: Politics in the Age of Equality (Washington D.C.: Regnery Publishing, 1992): 3

${ }^{23}$ Calhoun, C., "Civil Society and the Public Sphere," Public Culture, 5 (1993): 279

${ }^{24}$ Downey, J. and Fenton, N., "New Media, Counter Publicity and the Public Sphere," New Media and Society, 5.2 (2003): 200

${ }^{25}$ Faden-Kuhne, K., and Gabriel, Oscar W., "Mapping Political Participation," in Oscar W. Gabriel, Silke I. Keil and Eric Kerrouche (eds.) Political Participation in France and Germany (Colchester, ECPR Press, 2012): 34
} 


\section{4: THE CASE OF PAKISTAN}

\subsection{1: PAKISTAN - A STRUGGLING DEMOCRACY}

The last few years are markedly significant in the political history of Pakistan. For the first time, an elected civilian government completed its five-year constitutional tenure in 2013 and handed over power to another elected civilian government. So much so, the events of last few years have been dubbed as a strong indication for Pakistan's continuing democratic consolidation. ${ }^{26}$ Others are little cautious in their optimism and see Pakistan only just entering into the critical transitioning phase.$^{27}$ For them, democratic credentials in Pakistan can only be successfully realised if the grip on power exercised by traditional feudal elite, the growing disbelief of the masses in the institution of democracy and the role of powerful military in country's society and politics is altered. ${ }^{28}$ The first 11 years of Pakistan's history are critical for understanding how elitist tendencies got rooted in country's politics and policymaking.

\subsection{2: ROOTS OF ELITISM IN PAKISTAN}

In order to understand the roots of elitism and elitist policymaking, one has to go as far back as the independence movement of Pakistan and its sole spokesman - Muhammad Ali Jinnah - who, more or less, singlehandedly orchestrated the independent state of Pakistan in $1947 .^{29}$

\footnotetext{
${ }^{26}$ Malik, A., "Pakistan in 2013: A Milestone in Democratic Transition," Asia Survey, Vol. 54, No. 1 (2014): 177

${ }^{27}$ Ashraf, Muhammad I., "The Democratic Stature of Pakistan in the Contemporary World: Challenges and Prospects," The South Asianist, Vol. 2, No. 2 (2013): 125

${ }^{28}$ Waheed, Ahmed W. and Abbasi, Javeria Y., "Rethinking Democracy in Pakistan," Asia Affairs, Vol. 44, No. 2 (2013): 202

${ }^{29}$ Tudor, M., The Promise of Power: The Origin of Democracy in Indian and Autocracy in Pakistan (Cambridge: Cambridge University Press, 2013)
} 
His countrymen call him Quaid-e-Azam or the Great Leader, and consider him as the sole architect of the Country. Jinnah, as the first Governor General of Pakistan, was much more than a titular head of the State. He had full authority over the civilian administration and the armed forces. He could amend the existing constitution and promulgate laws. He not only took the charge of Cabinet-making upon him but also of the formulation of its policies. Jinnah's demise in September 1948, a little more than a year after the independence, as Callard writes "left a gap too big to be filled by any of his successors." ${ }^{30}$ One of the close aids of Jinnah and the former Prime Minister of Pakistan Chaudhri Muhammad Ali reflects, "Those in authority would have turned to him [Jinnah] for guidance [and] His judgment of men and affairs was beyond question...If the Cabinet decided, as it did a few months after the establishment of Pakistan that the Quaid-e-Azam could overrule the Cabinet, it was done for him as Quaid-e-Azam and not because he was the Governor General...a voluntary surrender of power on the part of the Cabinet in favour of the Father of the Nation. ${ }^{, 31}$ It is important to note that the Indian Independence Act of 1947 had restrained discretionary powers of the Governor-General who was now to act on the advice of his ministers. But Pakistan, instead, adopted the Act of 1935 whereby the Governor-General continued enjoying wide and substantial powers. Jinnah opted becoming the first Governor-General instead of assuming the office of the Prime Minister. It is argued that Jinnah's preference for centralization of power within the League as well as at the outset of Pakistan's political existence reinforced the trend to increasing reliance on a quasi-colonial style of governance and a propensity for authoritarian systems. ${ }^{32}$

\footnotetext{
${ }^{30}$ Callard, K., Pakistan: A Political Study (New York: The Macmillan Company, 1957): 20

${ }^{31}$ Ali, Chaudhri M., The Emergence of Pakistan (New York \& London: Columbia University Press, 1967): 385

${ }^{32}$ Tepper, Elliot L., "The New Pakistan: Problems and Prospects. Pacific Affairs, 47.1 (1974): 56; also see: Rose, Leo E., "Pakistan: Experiment with Democracy," in Larry Diamond, Juan J. Linz and Seymour Martin Lipset (eds.), Democracy in Developing Countries, Vol. 3 - Asia (Colorado:

Adamantine Press Limited, 1989)
} 
The independence had brought all governmental activities under the control of the Cabinet, which was responsible to the Constituent Assembly. The Constituent Assembly was setup with a numerical ratio of one member to one million inhabitants comprising representatives chosen by the elected members of the Provincial Legislative Assemblies constituted through elections held in 1945 - 46. The League had an overwhelming majority in the Assembly and had alone led the independence movement and scored an immense victory in the 1945 elections. The League turned into a party of elites with a strong belief that it had given Pakistan to the people and it was not to become an ordinary political party competing with others on equal terms for the favour of the electorate. ${ }^{33}$

Another issue that, at the time needed, intermediation of interests and politics of accommodation, was the confrontation between the East and the West wings of Pakistan on the issues of national language and provincial representation in the federal legislature. East Pakistan, the province of East Bengal, was only one-seventh of the whole in area, but its population exceeded the population of all the provinces in the West. Urdu language, at the time, was spoken by only 4 per cent of the total population while Bengali language was generally spoken in East Pakistan, which constituted more than half of Pakistan's population. The West was predominantly Muslim but the East had almost one-quarter of its population consisting of other religious minorities. Jinnah, himself, was the staunch advocate of the "Urdu-only" policy and considered it vital to foster solidarity and unity in the people of Pakistan. On the contrary, the language issue galvanized the people of East Pakistan into a populist movement demanding Bengali to be also declared as an official language. The movement turned violent as early as in 1948 and reached to its climax on February 21, 1952

${ }^{33}$ Callard, K., 1957: 38 
when the riot police killed several students of the Dhaka University during the protest.

Though, the language issue was resolved in the 1956 constitution by declaring both Urdu and Bengali as official languages, it had already paved the path of East Pakistan's secession movement. Even more importantly, the language movement had set the foundation for popular resistant to elitist policies in Pakistan by casting populism as a viable, and perhaps the only, medium for articulation of interests.

The first Constituent Assembly took seven years to produce the final draft of the constitution, which it accepted in September 1954. But before the Constitutional draft could have been proclaimed, the Constituent Assembly was dissolved by the then-Governor General Ghulam Muhammad on the ground that it has lost the confidence of the people. The League, once considered a representing party for the whole of Pakistan, had broken into different factions of Pakistan Muslim Leagues and witnessed a humiliating and shocking defeat in the 1954 provincial elections for East Bengal. It could only bag ten seats against 223 seats won by the United Front, a weak coalition of five Bengali parties that had run their campaign under the political slogan "Bengal for the Bengalis". ${ }^{34}$ Five months after the provincial elections, the then Governor-General Ghulam Muhammad dissolved the first Constituent Assembly and declared the "state of emergency." The decision to dissolve the Constituent Assembly created precedence for future validations by the higher judiciary of patently arbitrary, malicious and capricious acts of the executive on the doctrine of the "State necessity". ${ }^{35}$ Elections to the second Constituent Assembly were held on June 21, 1955. The League won only 33 seats in the new 80 members Constituent Assembly, which was to be divided equally between the East and the West Pakistan. The Second Constituent Assembly took another two years and

\footnotetext{
${ }^{34}$ Burks, Ardath W., "Constitution-making in Pakistan," Political Science Quarterly, 69.4 (1954): 544

${ }^{35}$ Khan, H., Constitutional and Political History of Pakistan (Oxford: Oxford University Press, 2001): 141; see also: Stavsky, Mark M., "The Doctrine of State Necessity in Pakistan," Cornell International Law Journal, Vol. 16 (1983): 341 - 394
} 
finally after nine years of political debacle, a new Constitution was finally adopted on February 29, 1956.

After the promulgation of the first Constitution, It had not taken long for the parliamentary governments in both West and East Pakistan to start showing disquieting features. It was widely feared that the evolution of parliamentary democracy, in a country like Pakistan where the political parties have hardly developed and public opinion is ill-organised, is likely to be slow and meet with many pitfalls. ${ }^{36}$ This particular discourse essentially implied that the country is unready for a full-fledged democratic system with its illiterate masses vulnerable of becoming victims of crafty politicians and needed, instead, some form of an autocratic rule. ${ }^{37}$ By October 7, 1958, when President Iskandar Mirza enforced nation-wide martial law due to widespread political unrest, the country had become virtually unmanageable and there were increasing cries for rebellion and secession in both wings of the country. ${ }^{38}$ Just two weeks after enforcing nation-wide martial law, President Iskandar Mirza was forced to step down by his own appointed martial law administrator and the Commander in Chief of the Pakistan Army Ayub Khan on October 27, 1958 after a bloodless coup d'état. It then comes as a paradox that immediate reaction from the general public to every military coup in Pakistan has been broadly favourable, which by the time of military takeover had thoroughly become disgruntled of the democratic process due to widespread political instability. ${ }^{39}$ This particular discourse that Pakistan is not yet ready for a full-fledged democratic rule and needed some form or another of elitist domination for good-governance found widespread tacit approval even during the last military coup of 1999 of General Pervez Musharraf. In

\footnotetext{
${ }^{36}$ Choudhury, G. W., "The Constitution of Pakistan," Pacific Affairs, 29.3 (1956): 252

${ }^{37}$ Sayeed, Khalid B., "Pakistan's Basic Democracy," Middle East Journal, 15.3 (1961): 249 - 263

${ }^{38}$ Ziring, L., Pakistan: At the Crosscurrent of History (Oxford: Oneworld Publications, 2003): 79

${ }^{39}$ Malik, Iftikhar H., "Military Coup in Pakistan: Business As Usual or Democracy on Hold," The Round Table, 360 (2001): 357
} 
2003, little less than four years in power, General Musharraf made this all too familiar statement that "Pakistan is not ready for democracy." ${ }^{40}$ Hussain Haqqani, the former ambassador of Pakistan to United States, writes that from Ayub Khan to Pervez Musharraf, every military dictator has argued that Pakistan is not ready for democracy. ${ }^{41}$ General Zia ul Haq consistently argued, "western style democracy is not suited to Pakistan, which should develop a system of Islamic democracy." 42

Throughout the history of Pakistan and by the time General Pervez Musharraf ousted the incumbent government in 1999, interest group membership and participation remained restricted and intermediation existed only arbitrarily often culminating into violent populism and contributing to downfalls of regime after regime. On the proposed framework, Pakistan mostly hovered around in the bottom left of the scale and only periodically shifted sidewise, i.e. during President Ayub Khan with his 'basic democracy’ and during General Zia ul Haq where intermediation with religious groups was institutionalised. Ironically then, it was not any civilian government but rather General Pervez Musharraf who opened up membership to interest groups and their new formations that triggered the country's upward movement from the bottom-left of the scale.

\subsection{3: INTEREST GROUPS IN PAKISTAN AND THEIR RISING INFLUENCE}

In its initial years of creation, the civil society in Pakistan took the form of secular-nationalist organisations along with religious trusts and seminaries providing food and shelter, first aid

\footnotetext{
${ }^{40}$ See: Hussain Haqani Op-Ed appeared on July 4, 2003 on Carnegie [accessed April 142014 (http://carnegieendowment.org/2003/07/04/u.s.-should-stop-indulging-musharraf/39jc?reloadFlag=1)]

${ }^{41}$ Haqqani, H., "History Repeats Itself in Pakistan," Journal of Democracy, Vol. 17, No. 4 (2006): $110-124$.

${ }^{42}$ Korson, J. H., and Maskiell, M., "Islamization and Social Policy in Pakistan: The Constitutional Crisis and the Status of Women." Asian Survey, Vol. 25, No. 6 (1985): 589 - 612
} 
and healthcare services for rehabilitation of migrants from India. ${ }^{43}$ During the first military rule [1958-1969], the voluntary associations continued playing supplementary role in provision of social services but the political role of such organisations was severely contained. In these early years, however, the civic institutions had started taking shape around bar councils, press clubs, professional associations and student unions in urban centres and clans in rural areas led by rich landlords and hereditary chieftains. With the growth of industrialisation in 1960s, the interest groups activities started becoming more visible in form of labour unions, traders associations, industrial bourgeoisies and urban professional. ${ }^{44}$ During Bhutto's time [1973 - 1977], development of interest groups activities took the first major setback as a result of nationalisation policies and expansion of state in economic, educational and cultural spheres, which brought labour unions and professional associations under the state control. During the last civilian rule [1988-1999], the civil society, especially the nongovernmental sector, started gaining ground and became more active and differentiated. Importantly, the burgeoning of civil society networks was all in the backdrop of General Zia's military rule of 1980s and in reaction to the implementation of his controversial Islamisation policy. ${ }^{45}$ Some of the earliest and well-known NGOs were established under General Ziaul Haq military rule in opposition to his controversial polices, especially in the domain of women and minority rights. The growth of civil society organization remained largely undisturbed after the October 1999 coup and in some sectors, i.e. women rights, it became even more vibrant.

\footnotetext{
${ }^{43}$ Rehman, A., Dynamism of Pakistan's Civil Society: Religious-Secular Rivalry and its Resources," Journal of International Development and Cooperation, Vol. 12, No. 2 (2006): 55

${ }^{44}$ ibid, 56

${ }^{45}$ Mustafa, B. and Brown, Katherine E., "The Taliban, Public Space and Terror in Pakistan," Eurasian Geography and Economics, 51.4 (2010): 504
} 
Pakistan Center for Philanthropy, a certification organisation for NGOs, has put the number of active NGOs in Pakistan to be anywhere between 100,000 to 150,000. In addition, there are today numerous trade unions, business associations, media and press and citizen clubs and community organizations, as well as clans, village and neighbourhood organizations existing at every level of the society. Shah, calling it the rise of the third sector, makes the case that the trend reached its climax in 1990 s and can be attributed to mainly three factors. ${ }^{46}$ First, the growing inability of the State to provide basic services to its citizens, second, the political dynamics of the time when foreign assistance to Pakistan aimed at promotion of democracy and strengthening of democratic institutions and, third, increased occurrences of natural disasters which further necessitated the need for the third sector to fill-in the gap. ${ }^{47}$ It was during the last military rule of General Pervez Musharraf [1999 - 2008] when the civil society, for the first time, started diversifying from previously having become synonymous with NGOs.

In order to gain political legitimacy and win-over the approval of the international community, General Pervez Musharraf had made considerable concessions during his 11year military rule in Pakistan by opening up the public space. As the result, by the time the civilian rule was returned, there were already a burgeoning media environment and a vibrant civil society networks existing in Pakistan. ${ }^{48}$ This was unlike previous military rules where centralisation and limitations on political freedoms had been the defining feature. By the time the 2008 elections were held, General Musharraf had lost considerable clout in the backdrop of widespread political instability and with his forced resignation as the army chief in

\footnotetext{
${ }^{46}$ Shah, F., "The Rise of the Third Sector and its Baneful Impact on Pakistan," Herald Exclusive, April 2014

${ }^{47}$ ibid

${ }^{48}$ Yusuf, H. and Schoemaker, E., "The Media of Pakistan: Fostering Inclusion in a Fragile Democracy?" BBC Media Action Policy Briefing 9, September 2013: 8
} 
November 2007. The political party - Pakistan Muslim League (Quaid) - that had supported General Musharraf throughout his military rule had lost majority in the national and provincial assemblies. Under immense political pressure, General Musharraf reluctantly resigned on August 18, 2008 as the President of Pakistan and the country once again returned to a popularly elected civilian government.

The changing dynamic in the political landscape of Pakistan of increasing interest groups activities and broadening of the public space have had visible impact on how public policies were shaped during the last regime. There are numerous instances that reflect increasing influence of special interests on how public policies were shaped and on their eventual outcome. Three cases, in particular, of renaming the North-West Frontier Province, devolution of the Higher Education Commission and attempts to privatise public entities highlight growing influence of interest groups in political outcomes but limited and arbitrary intermediation by the state to reflect their concerns in forging public policy solutions. Unlike in the past, these cases also show policy outcomes resulted through either comprise or stalemate between competing interests or ended in complete retraction by the state from its original position. This is reflective of growing pluralistic tendencies in the public policy making arena in Pakistan. However, due to absence of any institutionalised mechanisms of interest groups intermediation in public policy making, these outcomes could only be arrived through violent articulation of interests.

\subsubsection{1: Case One: Renaming of the North-West Frontier Province}

The North-West Frontier Province (NWFP) was given its name during the British rule and reflected more of a geographical location than having any meaningful significance. The 
names of other three provinces of Pakistan, on the other hand, reflect majority ethnic groups within them. The coalition government in 2008 took upon the task of reversing amendments made to the Constitution under the military rules of General Zia and General Musharraf through which the office of the president had amassed considerable powers. The Awami National Party (ANP), one of the coalition partners, had formed the government in NWFP and contested 2008 general elections on the premise of renaming NWFP as Pakhtunkhwa. This, as reflected in their manifesto, was "according to the aspirations of the people and resolutions of the provincial assembly." ${ }^{, 49}$ The proposed name reflected majority Pashtun population of the province but would have had no reference to a sizeable Hindko-speaking minority mostly concentrated in Hazara region. Since renaming the province required amending the Constitution with a two-thirds majority in both the upper and lower houses of the parliament, it was packaged together with other amendments needed to bring the country back to a parliamentary democracy. The renaming clause was added in the constitutional amendment bill. The second leading party in the national parliament Pakistan Muslim League (Nawaz), however, opposed renaming the province as Pakhtunkhwa since it had always drawn more political support from the Hindko-speaking areas of NWFP ${ }^{50}$ Since early $1980 \mathrm{~s}$, local political parties and civil society groups had been campaigning for a separate province made of the Hazara region. The renaming of NWFP as Pakhtunkhwa gave impetus to the demand of a separate province to these groups. Among the main interest groups pursuing for a separate province, which also opposed renaming NWFP included Hazara Students Federation, Hazara District Bar Associations, All Traders Federation of Abbottabad, District Press Clubs in Hazara and Union of Journalists in Abbottabad, among others. The main political movements based in Hazara that rallied against renaming NWFP included Hazara

\footnotetext{
${ }^{49}$ According to section 2.1, clause 2 of the Awami National Party's 2008 election manifesto [accessed March 18, 2014 (http://awaminationalparty.org/main/?p=2963)]

${ }^{50}$ Mushtaq, M., Muhammad, A. and Alqama, Syed K., "Politics of Power Sharing in Post-1971

Pakistan," Journal of Politics and Law, Vol. 4, No. 1 (2011): 253
} 
Tehrik (Hazara Movement), Hazara Province Tehrik (Hazara Province Movement), Tehrik-iHuquq-e-Hazara (Movement for the Rights of Hazara), and Hazara Qaumi Mahaz (Hazara National Front). ${ }^{51}$ For the first time, these groups appeared on the national scene making alliances with mainstream political parties and bargained for favoured public policy outcomes in return for their support in 2013 general elections.

In the backdrop of violent protests that had erupted all over Hazara region over renaming the province as Pakhtunkhwa, major political factions started negotiations to find a compromise. As the result, the word Khyber was added to the proposed name. On April 15, the government signed 18th amendment into the law and in addition to reversing the alterations made to the Constitution during the military rules also included a clause of renaming NWFP as Khyber Pakhtunkhwa. The addition of word "Khyber," which refers to a historic mountain passage linking Pakistan and Afghanistan, was primarily a bid to lessen the ethnocentric connotation of the originally proposed name. This did little to appease the Hindko-speaking population of the province, as they had demanded the word Hazara to be added to the name. As the result, violent protests once again broke but soon dissipated as leading political parties had come to a compromise. Before the eighteenth amendment, no individual could hold the office of the Prime Minister for the third term. With the support from Awami National Party, Pakistan Muslim League-Nawaz was able to take out this clause from the Constitution and paved the way for the third-time Premiership for Nawaz Sharif.

This incident is remarkable for three reasons. Firstly, it represents a competition among different political factions trying to press for a policy outcome favoured by a plurality that they represented but eventually had to come to a compromise. Secondly, the day the

\footnotetext{
${ }^{51}$ Ahmar, M., "Conflict Prevention and the New Provincial Map of Pakistan: A Case Study of Hazara Province," Journal of Political Studies, Vol. 20, No. 2 (2013): 1-19
} 
renaming of the province resurfaced, the issue was debated, contested and lobbied not just in formalized institutions, i.e. parliament or the parliamentary committees, but also through the media and with display of collective will in form of demonstrations. Lastly, smaller groups that represented local interests and felt their demands have not been fully heard by mainstream political factions became stronger and more organised now demanding a separate province for Hindko-speaking areas. ${ }^{52}$ The incumbent coalition government in Khyber Pakhtunkhwa province of Pakistan Tehreek-e-Insaf (Pakistan Justice Movement) campaigned on this very issue in Hazara region for 2013 general elections and made significant inroads for the very first time.

\subsubsection{2: Case Two: The Devolution of the Higher Education Commission of Pakistan}

The $18^{\text {th }}$ amendment had enacted more than 100 changes to the Constitution of Pakistan, including devolution of power and greater autonomy to provinces. As the result, several subjects once dealt at the federal level, including education, are now the prerogatives of provinces. With education now a provincial subject, it was decided to delegate various mandates of the Higher Education Commission (HEC) of Pakistan also, which was working as the primary regulator of higher education in the country. Responsibilities of Higher Education Commission included managing grants to higher education institutions, policy development, quality assurance, degree recognition and development of new and uplift of existing educational institutions in Pakistan. ${ }^{53}$

\footnotetext{
${ }^{52}$ Baloch, B., "What's in a Name?" Foreign Policy, April 26, 2010

${ }^{53}$ On history and constitutional status of Higher Education Commission of Pakistan, see: [accessed June 122013 (http://www.hec.gov.pk/Pages/UniversityBuilding.aspx)]
} 
As the devolution of several subjects, once federal, could have not taken place overnight, a parliamentary commission was specifically established for the implementation of the eighteenth amendment in a phased manner. The parliamentary commission saw no role of HEC in the future except setting standards and regulation of higher education, according to the commission's interpretation of the 18th amendment. As the announcement was made to devolve various functions of HEC to provinces in March 2011, academics in general and higher education institutions in particular vociferously opposed this decision. This culminated into nationwide demonstrations where students and sections of civil society joined forces and latter rival political factions also joined the chorus. In the build-up to nationwide protests, vice chancellors from public sector universities, led by HEC Chairperson, held meetings with the Parliamentary Implementation Commission pressing upon its members to reverse its intention to devolve HEC because of its past performance, future need and incapacity of provinces to manage higher education. Smaller provinces, on the contrary, saw channelling of funding through HEC to universities as unjust and something that should have been under their purview. Raza Rabbani, Chairman of the Implementation Commission of the 18th Amendment, summed up the same sentiment when he announced the decision to devolve HEC on March 30, 2011 by stating that "we are going to end the financial monopoly of the HEC once and for all as it has always acted beyond its purview."

As the momentum started building up against the government's decision to devolve HEC, two private sector universities filed a petition in the Supreme Court of Pakistan. By the second week of April 2011, the government had already succumbed to intense pressure yielded from academia, students and rival political factions and announced releasing frozen 
funds of HEC withheld by the Ministry of Finance. ${ }^{54}$ The same week, Supreme Court ordered restoration of all privileges of HEC until the amendment in the concerned law prevails. While a private bill was prepared to amend the concerned ordinance, it was never presented before the parliament. It has been more than three years since the passing of the eighteenth amendment but HEC is yet to be devolved. There is now a new government in the Center that had sided against the decision of devolving HEC to province. The case of devolution of HEC shows how competing interests resorted to a stalemate. Those who had opposed devolution were able to successfully rally popular sentiments against the decision and side-by-side used legal means. The government and its coalition partners, on the other hand, sensing the popular sentiments against the devolution of HEC preferred to leave the decision to the next government. It is highly unlikely that the present government at the Centre will raise this contentious issue once more. $^{55}$

\subsubsection{3: Case Three: The Privatisation Experience}

Since the establishment of the Privatisation Commission in 1991, it has undertaken 167 transactions liquidating part or complete ownership of state-owned enterprises. While the bulk of the transactions were carried out during the civilian rule from 1991 to 1999 , the most lucrative ones could only be completed during the military rule of General Pervez Musharraf. During the previous government, however, only one transaction was matured and 23 remained unfinished (see Table 6.1).

\footnotetext{
${ }^{54}$ Musarrat, R., Ali, G. and Azhar, Muhammad S., " $18^{\text {th }}$ Amendment and its Impact on Pakistan's Politics," Journal of Sociological Research, Vol. 3, No. 1 (2012): 6

${ }^{55}$ See: December 92012 article by the Express Tribune [accessed June 122013 (http://tribune.com.pk/story/477185/hec-and-devolution-getting-the-third-degree/)]; also December 20, 2012 article by Express Tribune [accessed June 122013 (http://tribune.com.pk/story/482109/bravo-supreme-court/)]
} 
If seen from the perspective of number of completed transactions, one could argue that the bulk of the privatisation process had already been completed during the civilian rule from 1991 to 1999 and during the military government from 1999 to 2008, a snapshot of 2011 and 2012 suggests otherwise. Protests have continued throughout these two years by several workers' and employees' unions belonging to a wide range of economic and commercial sectors that either managed reversal or putting on hold the decision on privatisation. So much so, of the 26 public entities that the government had decided to privatise in 2011 , not a single transaction could materialise. Late in 2011, the then Information Minister Firdous Ashiq Awan announced, after a cabinet's meeting, that the decision to privatise eight public entities, including Pakistan International Airlines, Pakistan Railway and Pakistan Steel Mills, have been reversed and these organisations will now be made profitable while remaining within the government's ownership. The privatisation experience during the present government is a vivid manifestation of increasing activity by various interest groups. It also reflects inability of the government to take account of special interests when public policies are forged. ${ }^{56}$

The above discussion shows how policy decisions originally taken by the last government had to be altered or reversed because of increase in activity and influence by different interest groups. These are yet a few among many policy decisions from which Pakistan Peoples Party-led coalition government had to withdraw. In July 2008, the cabinet's decision to place Inter-Services Intelligence under the civilian control badly backfired and had to be withdrawn. In March 2009, the government was succumbed into reinstating Chief Justice

\footnotetext{
${ }^{56}$ Discussion is based on several newspaper articles as well as official statistics from the Privatization Commission of Pakistan; for comprehensive newspaper articles, see: June 172011 article by Express Tribune [accessed June 152013 (http://tribune.com.pk/story/190546/change-of-hands-firstprivatisation-deal-in-three-years-expected-by-sept/)]; also March 62012 article in Dawn, English daily [accessed June 152013 (http://x.dawn.com/2012/03/06/privatisation-may-fetch-rs32bn/)]; also August 192011 article by Dawn, English daily [accessed June 152013 (http://beta.dawn.com/news/653147/the-politics-of-privatisation)]
} 
Iftikhar Muhammad Chaudhry against its wishes. On December 30 2010, the government publicly backed out from its earlier intention to amend the controversial blasphemy law. On March 4 2011, the government reversed its decision to increase fuel prices and sales tax as per the promises made to the International Monetary Fund. In September 2012, the government caved in on the issue of writing an official letter to Swiss authorities on opening up cases against President Asif Ali Zardari on money laundering. While each policy decision and its reversal merits individual inquiry as they have somewhat varying context, dimensions and fallouts but they all have in common the government's persistence on elitist tendency and no visible mechanism of institutionalising interest groups articulation into public-policy making. As a result, interest groups had to increasingly rely on populist means to have their voices heard. This tension between various interest groups and the government could have easily plunged the country into deep political crisis if the policy decisions were not reconsidered. Ironically, what actually survived the government was its weakness and reliance on coalition partners who signalled pulling out their support when ever realising a policy decision lacks popular support. But every such instance made the government look weaker and kept the undemocratic forces interested in politics.

As opposed to the 1990s, the preceding discussion reflects increasing tendency by the power elites to opt for a strategy of accommodation in formulation of public policies to appease to a broad section of the polity and dissipate, as much as possible, popular dissent. Discussion also shows opening up of channels of interests' articulation by individuals and groups in Pakistan, which goes beyond traditional and formalised institutions. It is also observable that smaller interest groups have become stronger and better organised with every populist manifestation. Side-by-side, it is evident from discussed cases that there are no institutionalised mechanisms for interest groups intermediation in formulation of public 
policies resulting into populist means of articulation of interests that have often turned violent. Without institutionalisation of interest groups, especially in struggling democracies where political parties are weak, the political system remains insufficiently informed and of lacking the adequate support of concerned groups. Institutionalisation allows continuous interaction between state and society with structured representation of interests and giving protection to the state and the government from fluctuating and overwhelming demands of the society. ${ }^{57}$

Applying these findings to the theoretical framework presented in Section 3, there has been visible increase in interest groups activities in Pakistan trying to break free from its elitist past. Ironically, the burgeoning of interest group activities is the result of measures taken by General Musharraf in order to boast his democratic credentials. At the same time, there has been no visible effort, even under the civilian-led rule, of institutionalising interest groups intermediation in formulation of public policies. As a result, this process has been done arbitrarily and mostly in response to violent demonstrations. This, in case of Pakistan, is pulling the country off from its transition to consolidation of democracy and towards populism, with adverse consequences for the country's political stability and institutional development. The pluralist model assumes a functioning democracy with low level of formal institutionalisation of interest groups. In struggling democracies, however, pluralistic articulations of interests and demands have yet to take roots and the political system lacks capacity to generate policy-outputs to accommodate greater number of inters groups demands. ${ }^{58}$

\footnotetext{
${ }^{57}$ Agh, A., "Post-Accession Crisis in the New Member States: Progressing or Backsliding in the EU?" Studies of Transition States and Societies, Vol. 2, No. 1 (2010): 84

${ }^{58}$ Offe, C., "The Attribution of Public Status to Interest Groups," in Claus Offe (ed.) Disorganized Capitalism, (Cambridge, Ma: The MIT Press, 1985): 224
} 


\section{5: CONCLUDING WORDS}

Pakistan's political history has been at best a playfield for rival elites defending their interests and making it nearly impossible for the country to set a foothold on the path to democracy consolidation. Today there is, however, a reason for optimism. The burgeoning media, senior judiciary muscling for independence and revitalisation and strengthening of civil society networks have helped broadening the existing public sphere and impacted how political actions are taken today. This changing dynamics on the political landscape of Pakistan are not without its pitfalls. Religious extremism, growing militancy, ethnic and sectarian rivalries and deteriorating human security in general are all among negative forces keeping Pakistan politically unstable. This coupled with increasing populism poses serious threat to the country's transition to democracy. In order to bring political stability and strengthen transition to democracy, interest groups intermediation in making of public policies has to be institutionalised. It will take time for the pluralist culture to take firm roots in Pakistan. In the short-run, formal institutionalisation much in line with the model of neocorporatism could help achieve this cause. With the simple majority in the centre and in Punjab, the largest province, it will perhaps be harder for the incumbent government of Nawaz Sharif to let go its elitist past. But it would have to learn from the debacles made by its predecessor, as the outfalls will be far graver than in the past. 


\begin{tabular}{|l|l|l|l|}
\hline \multicolumn{3}{|l|}{ Table 6.1: Privatisation in Pakistan by Completed Transactions and Volume } \\
\hline Tenure & Period & Completed Transactions & $\begin{array}{l}\text { Volume } \\
\text { (Billion Rupees) }\end{array}$ \\
\hline During the civilian rule & $1991-1999$ & 101 & 58.8 \\
\hline During the military rule & $1999-2008$ & 66 & 416.2 \\
\hline During the PPP-led & $2008-2013$ & 1 & 1.3 \\
government & & & \\
\hline
\end{tabular}

Source: Privatisation Commission of Pakistan 
Figure 6.1: Interest groups Membership, Participation and Intermediation in Public Policy Making

Open
Interest groups
participation/
membership




\section{RESEARCH METHODOLOGIES AND DESIGN}

\section{1: INTRODUCTION}

s described in Chapter 4, the overall methodological approach of 'policy-as-
discourse' is applied for this research. Policy-as-discourse, as with other forms
of discourse analysis, involves exploring the process of meaning creation. ${ }^{1}$

Fischer writes, "A policy-as-discourse analysis incorporates qualitative methods to illuminate the processes whereby reality comes into being. ${ }^{2}$ Russell et al argue the same and assert, "Making visible the role of language, argument and discourse in policy discussions has the potential to play an emancipatory role in giving policymakers new insights into their work, and increasing awareness of the conditions that shape their actions and choices." ${ }^{3}$ For Russell et al, "policy-making in practice depends crucially on what is said, by whom, and on whether others find their arguments persuasive," and therefore, "require a framework of ideas that addresses the role of language, argument and discourse [italic added]." ${ }^{, 4}$ Their basic thesis calls for analysing policy problems qualitatively and in their social and political context.

The next section provides reasons for using case study approach for undertaking the qualitative research followed by a section on selecting Pakistan as the study area. Sections 6.4 and 6.5 briefly discuss the research framework employed to collect the information and

\footnotetext{
${ }^{1}$ Goodwin, S., "Women, Policy and Politics: Recasting Policy Studies," in Angelique Bletsas, Chris Beasley (eds.) Engaging with Carol Bacchi: Strategic Interventions and Exchanges (Adelaide: University of Adelaide Press, 2012): 170

${ }^{2}$ See: Fischer, F., Reframing Public Policy: Discursive Politics and Deliberative Practices (Oxford: Oxford University Press, 2003); Yanow, D., Conducting Interpretative Policy Analysis (London, Sage, 2000)

${ }^{3}$ Russell, J., Greenhalgh, T., Byrne, E. and McDonnell, J., "Recognizing Rhetoric in Health Care Policy Analysis," Journal of Health Sciences Research and Policy, Vol. 13, No. 1 (2008): 45

${ }^{4}$ Ibid, 41
} 
the sample size and sampling methodology used for this research. Section 6.6 and 6.7 discuss the unit of analysis and major sources of information accessed for collecting data. Section 6.8 provides further details about collection of data and its recording and documentation.

Sections 6.9 and 6.10 provide brief overview of the tools used to collect and the steps taken to analyse date. Section 6.11 discusses limitations of this research followed by a concluding section.

\section{2: CASE STUDY APPROACH}

The methodology for this research is based on qualitative principles and founded upon 'case studies.' In study of public policy, case study approach is the most common and stresses upon substance. ${ }^{5}$ Case study research has a long history within science, social science and humanities and applied to a variety of disciplines, based on quantitative and qualitative research strategies, including anthropology, business and management, education, feminism, medicine, political science, psychology and tourism, among others. In public policy, as a subfield of political science, case study research is based on qualitative research methods and used to enhance understanding of the policy-making process. ${ }^{6}$ One of the main aims of case study research in public policy is to bridge the gap between the academic world of rational and normative approaches as to how public are designed and the practical world of policy making, which is far more messier and complex. Case studies are particularly well suited for tracing ideas because of their ability to invest heavily in discourse analysis. ${ }^{7}$

\footnotetext{
${ }^{5}$ Meier, Kenneth J., The Politics of Sin: Drugs, Alcohol, and Public Policy (New York: M. E. Sharpe, Inc., 1994): 3

${ }^{6}$ See entry "Case Study Research in Public Policy," in Alberta J. Mills, Gabrielle Eurepos and Elden Wiebe (eds) Encyclopedia of Case Study Research (London: Sage, 2010): 117

${ }^{7}$ See entry "Case Study," in Lisa M. Given (ed.) The SAGE Encyclopedia of Qualitative Research Methods (London: SAGE, 2008): 68
} 
The choice of 'case study' approach for this research is, therefore, an obvious one. Public policy is among those sociological phenomena that cannot be fully studied with the application of limiting methodological framework derived from the neopositivist and empiricist methods alone. As Yin writes, "the distinctive need for case studies arises out of the desire to understand the complex mix of these [individual, organisational, social and political] phenomenon." ${ }^{, 8}$ Yin argues that case study approach is particularly preferable when questions of 'how and 'why' are being posed. ${ }^{9}$ Merriam argues similarly that case study is best suited when the objective is to understand phenomenon of "complex social units consisting of multiple variables of potential importance." ${ }^{\prime 10}$ Merriam defines 'case study' as an "in-depth description and analysis of a bounded system," where she describes the 'bounded system' as the object of the study that could be a person, a group, an institution, a community or a specific policy. ${ }^{11}$

\section{3: THE STUDY AREA}

This research is conducted in Pakistan as one of the 'grey-zone' countries. In today's political landscape, a 'grey-zone' has emerged that include many regimes which fit neither the traditional democratic nor the classic authoritarian mould. ${ }^{12}$ Carothers explains grey-zone countries "have some attributes of democratic political life, including at least limited political space for opposition parties and independent civil society, as well as regular elections and democratic constitutions. Yet they suffer from serious democratic deficits, often including poor representation of citizens' interests, low levels of political participation beyond voting,

\footnotetext{
${ }^{8}$ Y in, R., Case Study Research: Design and Methods, (London: Sage Publications, 1988): 14

${ }^{9}$ Ibid

${ }^{10}$ Merriam, Sharan B., Qualitative Research: A Guide to Design and Implementation (San Francisco: Jossey-Bass, 2009) 50

${ }^{11}$ Ibid, 40

${ }^{12}$ Stewart, S. (ed.), Presidents, Oligarchs and Bureaucrats: Forms of Rule in the Post-Soviet Space (Surrey: Ashgate, 2012): 2
} 
frequent abuse of the law by government officials, elections of uncertain legitimacy, very low-level of public confidence in state institutions, and persistently poor institutional performance by the state." ${ }^{13}$ As per the latest data released by Freedom House on political rights and civil liberties for 2016, the number of countries in the grey-zone are from some where in between 59 to 97, including Pakistan, those classified as 'partially free' or those classified as 'partially free' and 'not free' but not amongst the 'worst of the worst. ${ }^{14}$

As described in Chapter 2, regime classification has been a subject of considerable debate in political science but there is generally a scholarly consensus over the existence of a 'political grey-zone.' Regimes falling into this have been variously termed from nondemocratic regimes to politically closed and in between as electoral authoritarian, pseudo-democratic or simply hybrid. ${ }^{15}$ The purpose of this research is to contribute towards building a theoretical foundation for making sense of policymaking process in grey-zone countries. This begs the question which regimes fall inside this grey-zone.

Diamond writes "few conceptual issues in political science have been subjected to closer or more prolific scrutiny in recent decades than this problem of "what democracy is... and is not," and which regimes are democracies and which not. ${ }^{16}$ As a result, we have a plethora of definitions, standards and tools of measurement. Diamond himself uses Freedom House data on political rights and civil liberties and applies more stringent criteria to arrive at five classifications with 'liberal democracies' at one end and 'politically closed authoritarian

\footnotetext{
${ }^{13}$ Carothers, T., "The End of the Transition Paradigm," Journal of Democracy, Vol. 13, No. 1 (2002): 9-10

${ }^{14}$ Freedom House, Freedom in the World $2016<$ https://freedomhouse.org/report/freedomworld/freedom-world-2016>, accessed on August 19, 2016

${ }^{15}$ Diamond, L. "Elections Without Democracy: Thinking About Democracy," Journal of Democracy, Vol. 13, No. 2 (2002): 25

${ }^{16}$ Diamond, L., "Thinking about Hybrid Regimes," Journal of Democracy, Vol. 13, No. 2 (2002): p. 21
} 
regimes' at the other. ${ }^{17}$ Freedom House albeit is one among many indices available on regime classification. The Global Peace Index, which is now in its tenth edition and ranks 163 countries, classifies governments in four types, namely 'full democracy,' 'flawed democracy, 'hybrid regime' and 'authoritarian regime.' Bertelsmann Stiftung's Transformation Index analyses and evaluates the quality of democracy in 129 developing and transition countries, namely 'democracy in consolidation,' 'defective democracy,' 'highly defective democracy,' 'moderate autocracy' and 'hard-line autocracy. ${ }^{18}$ Among other widely used indices with credible coverage is the Polity IV Project, which classifies countries as 'full democracy,' 'democracy,' 'open anocracy,' 'closed anocracy,' 'autocracy,' and 'failed/occupied' states. However, all indices have been criticised in one way or another for their theoretical, methodological, and analytical weaknesses. In case of Freedom House, Giannone has even argued that the neoliberal climate in which the index was conceived has affected the construction of its scale. ${ }^{19}$ Freedom House democracy ratings have also been criticised of being politically biased. Steiner assesses the validity of this criticism by using variables that record relationship of other countries with the US and finds a strong and consistent evidence of a substantial bias. ${ }^{20}$ An examination of latest available scores and the regime classification of Pakistan from leading democracy indices present discrepancies (see table 7.1). While Pakistan is not classified as a full democracy in any index but its status ranges from being classified as 'democracy' in Vanhanen's Index of Democracy and Polity IV to a 'hard-line autocracy' in Bertelsmann Stiftung Transformation Index and 'very low' in Democracy

\footnotetext{
${ }^{17}$ Ibid

${ }^{18}$ For a comprehensive listing of indices ranking countries against economic, political, environmental and social measures, see: Bandura, R. A Survey of Composite Indices Measuring Country Performance (New York: United Nations Development Programme, 2008)

${ }^{19}$ Giannone, D., "Political and ideological aspects in the measurement of democracy: the Freedom House case", Democratization, Vol. 17: No. 1 (2010): 68 - 97

${ }^{20}$ Steiner, Nils D., "Comparing Freedom House Democracy Scores to Alternative Indices and Testing for Political Bias: Are US Allies Rated as More Democratic by Freedom House?," Journal of Comparative Policy Analysis, (2014): 1 - 21
} 
Ranking. Högström also reaches the same conclusion when he compares indices of democracy, namely Freedom House, Polity IV, and Economist Intelligence Unit, based on dichotomous, tri trichotomous, and continues measures and found discrepancies in all comparison. $^{21}$

Nevertheless, Freedom House remains one of the oldest and the most widely used of available indices. It is also conducted every year and has a universal dataset, unlike any other indices. ${ }^{22}$ Freedom House, together with Polity IV, are generally cited as 'proof' of a country's level of democracy in policy circles. ${ }^{23}$ Among available datasets, Freedom House's index appears to be appropriately precise, temporally stable and, as Armstrong argues, lately there has been an effort to make as rigorous and transparent as possible. ${ }^{24}$ Also the maximalist definition of democracy used in Freedom House index allows further dissection of collected data and information, which is helpful in generating further categories, i.e. electoral democracy or a polyarchy. ${ }^{25}$ Gugiu and Centellas argue that in view of contradictory scores assigned by different democracy indices it is essentially left to the scholar to choose the best suits their research and to their knowledge of the country. ${ }^{26}$ In Chapter 2, it is argued that theories of public policy is in need of further advancement through application of theoretical frameworks that are value-free and are blind to any particular regime type. This is also the aim of this research.

\footnotetext{
${ }^{21}$ Högström, J., "Classification and Rating of Democracy," Taiwan Journal of Democracy, Vol. 9, No. 2 (2013): $33-54$

${ }^{22}$ For analytical and methodological comparison between leading indices, see: McMahon, E., and Kornheiser, E., "Assessing the Assessors: Correlating Democracy Methodologies," Social Indicators Research, Vol. 97, No. 2: $269-277$

${ }^{23}$ Ibid, 276

${ }^{24}$ Armstrong, David A., "Stability and Change in the Freedom House Political Rights and Civil Liberties Measures," Journal for Peach Research, Vol. 48, No. 5 (2011): 653

${ }^{25}$ Denk, T., "How to Measure Polyarchy with Freedom House: A Proposal for Revision," Quality and Quantity, Vol. Vol. 47, No. 6 (2013): 3457

${ }^{26}$ Gugiu, Mihaiela R., and Centallas, M., "The Democracy Cluster Classification Index," Political Analysis, Vol. 21 (2013): 347
} 


\section{4: RESEARCH FRAMEWORK}

The ten-step framework introduced by Hajer for discourse analysis is adopted for undertaking this case-study research (see table 7.2) ${ }^{27}$ As in case studies, the ten-step framework is designed to bring out the details from the viewpoint of the actors in the policy process by using multiple sources of data. Interviewing key players, one of the steps in Hajer ten-step frameworks, is however considered indispensible in case study research. ${ }^{28}$ The first step, in Hajer ten-step framework, consists of desk research that has helped identifying key actors involved in the policy process. This stage is followed by helicopter interviews that were conducted with subject experts and journalists who had written on legislations selected for this research to further confirm the findings of the desk research. Once the actors were identified, in-depth interviews were conducted and in each interview respondents were asked to identify whom they thought played an important role in the legislation to snowball interviews. In addition, parliamentary records, minutes of the meeting, resolutions and press releases were also studied. From the interviews, positioning effects were analysed to determine the role of power in discourse. In the next stage, a timeline was constructed and corroborated with the one developed through desk research to identify all key incidents essential to understanding the discursive dynamics in the chosen cases. This was followed by analysis of practices, through study of reporting and media coverage, of particular cases of argumentation. The collected data in the final leg of research was interpreted for coming up with an account of discursive structures created for and during the legislative process. The

\footnotetext{
${ }^{27}$ Hajer, Maarten A., "Doing Discourse Analysis: Coalitions, Practices, Meaning," in Margo van den Brink and Tamara Metze (eds.) Words Matter in Policy and Planning: Discourse Theory and Method in the Social Sciences (Utrecht: Netherlands Graduate School of Urban and Regional Research, 2006): 73

${ }^{28}$ Gillham, B., Case Study Research Method (London: Continuum, 2010): 59
} 
final stage consists of second visit to key actors, which in this research was needed in just one case.

\section{5: SAMPLING AND SAMPLE SIZE}

In qualitative research, saturation is used as a guiding principle for number of interviews to be conducted during data collection. A review of published sources on guidelines for actual sample size for a qualitative study range from a low of 15 to a high of 60 interviews. ${ }^{29}$ In qualitative research, however, the aim of the study and its design are the ultimate driver of the sample size. ${ }^{30}$ Morse, for instance, writes, "estimating the number of participants in a study required to reach saturation depends on a number of factors, including the quality of data, the scope of the study, the nature of the topic, the amount of useful information obtained from each participant, the number of interviews per participant, the use of shadowed data, and the qualitative method and study design used." 31 The assertion made by Jette, Grover and Keck is particularly relevant to this research that the expertise in the chosen topic also determine the number of participants needed in a study. ${ }^{32} \mathrm{~A}$ total of 30 in-depth interviews are conducted for this research with key actors involved in the legislative process.

For this research, snowball sampling is used starting from the main protagonists behind the public policy outcome and then identification of and reaching out to the most influential policy actors. Snowball sampling is helpful in cases where the actual population size is unknown and due to which a fixed sampling plan from the outset of the investigation cannot

\footnotetext{
${ }^{29}$ Mason, M., "Sample Size and Saturation in PhD Studies Using Qualitative Interviews," Forum: Qualitative Social Research, Vol. 11, No. 3 (2010): Art. 8

${ }^{30}$ Ibid

${ }^{31}$ Morse, J. M., "Determining Sample Size," Qualitative Health Research, Vol. 10, No. 1 (2000): 3

32 Jette, Diane U., Grover, L., and Keck, Carol P., "A Qualitative Study of Clinical Decision Making in Recommending Discharge Placement from the Acute Care Setting," Physical Therapy, Vol. 83, No. 3 (2003): $224-236$
} 
be developed. ${ }^{33}$ Another advantage of snowball sampling, which is relevant in this research, is that it enables identification of key actors in the policy process when it would otherwise a near impossible task. Snowball sampling is particularly applied in mapping out policy networks as "critical mediating variables that affect the distribution of power, the construction of interests and identities, and the dynamics of interaction," in an institutional context. $^{34}$

\section{6: UNIT OF ANALYSIS}

There seems to be no consensus on what should ideally be the unit of analysis in the study of public policies. ${ }^{35}$ From one study to another, the unit analysis varies in public policy studies. The most commonly used unit of analysis in public policy studies is 'public policy. ${ }^{36}$ Craig also agrees that in policy studies the central unit of analysis is usually the policy itself. ${ }^{37}$ In case study research, however, the unit of analysis is the 'bounded system' or the case selected for study. ${ }^{38}$

For this research, the basic unit of analysis is the policy subsystem. As the research is concerned more with the how and why of public policy of selected cases of social sector legislation, the research follows the dictates of the Advocacy Coalition Framework approach. Sabatier and Jenkins-Smith define policy subsystems as "substantive topic and territorial

\footnotetext{
${ }^{33}$ Merkens, H., "Selection Procedure, Sampling, Case Construction," in Uwe Flick, Ernst von Kardorff and Ines Steinke (eds.) A Companion to Qualitative Research (London: Sage, 2004): 168 ${ }^{34}$ Ansell, C., "Network Institutionalism," R. A. W. Rhodes, Sarah A. Binder and Bert A. Rockman (eds.) The Oxford Handbook of Political Institutions (Oxford: Oxford University Press, 2006): 75 ${ }^{35}$ Huang, R., "On the Nature of Public Policy," Chinese Public Administration Review, Vol. 1, No. 3/4 (2002): 275

${ }^{36}$ Hill, M. (ed.), Studying Public Policy: An International Approach (Bristol: Policy Press, 2014): 16

${ }^{37}$ Craig, John E., "Implementing Educational Policies in Sub-Saharan Africa: A Review of the Literature," World Bank Discussion Paper: Education and Training Series (1987): 25

${ }^{38}$ Merriam, Sharan B., Qualitative Research: A Guide to Design and Implementation (San Francisco: Jossey-Bass, 2009): 54
} 
domain along with a set of people actively involved in shaping subsystem affairs." ${ }^{, 39}$ As a nested or embedded unit, the focus of this research is, therefore, particularly on social-sector policy. ${ }^{40}$ In case study research, the sample is purposefully selected based on informationrich case studies. There is no precise rule as to the number of cases that should be selected and generally the criteria of theoretical saturation and information redundancy are applied, albeit recommendations made in the relevant literature range from 4 to $15 .^{41}$ In this research, the particular type of case study applied is what Yin refers to as 'descriptive' requiring a descriptive theory to be developed before starting the project or what Stake calls 'collective' where a number of cases are studied "to investigate a phenomenon." ${ }^{42}$ A total of three case studies are selected on the basis of all social-sector legislations passed by the Thirteenth National Assembly in Pakistan during it five year tenure as a separate set of laws, rather than amendments made to existing pieces of legislations.

\section{7: SOURCES OF INFORMATION}

Three major sources of information are used to carry out the ideational analysis of the three selected social bills. First, an extensive review of published literature was conducted that included journal articles, conference proceedings, technical reports and books. The second information source used for analysis comprises newspaper reports and government records, i.e. minutes of the meeting, as well as parliamentary debates. The third source of information consists of in-depth interviews with actors involved in the legislative process.

\footnotetext{
${ }^{39}$ Sabatier, Paul A., and Jenkins-Smith, H., "The Advocacy Coalition Framework: An Assessment," in Paul Sabatier (ed.) Theories of Policy Process, 2nd ed. (Boulder, CO: Westview Press, 1999): 17 20

${ }^{40}$ See: Yin, Robert K., Application of Case Study Research (London: Sage, 2012): 3 - 20

${ }^{41}$ See entry "Sampling," in Alberta J. Mills, Gabrielle Eurepos and Elden Wiebe (eds) Encyclopedia of Case Study Research (London: Sage, 2010): 837

${ }^{42}$ Stake, Robert E., The Art of Case Study Research (London: Sage, 1995); Yin, Robert K. Case Study Research: Design and Methods (London: Sage, 2003); on types of case study research also see Merriam, Sharan B., 2009: 46 - 49
} 
For the purpose of review, published literature discussing the particular legislation or its related aspect was included. Published literature was retrieved through variety of search engines, including EBSCOHost, JStor, Science Direct, direct access to Oxford and Cambridge Journals, Emerald, ProQuest and Elsevier Science. Various combinations of search terms were utilised to access relevant literature while primary combinations of search strings contained the full or short titles of the legislation and references to main instances or actors involved. Relevant literature was further indexed according to its relevance to the analysis.

The second source of information consisted of newspapers, government records and official reports. Four English-language newspapers, namely Dawn, The News, The Nation, and The Express Tribune, which together covers most of the national circulation in Pakistan, were searched for relevant information wherein all instances of the long or short title of the selected bills in news reporting were reviewed. Parliamentary records available at official website of Pakistan National Assembly and Senate of Pakistan, such as debates in the National Assembly and legislative business conducted in the Senate were also studied.

The third sources of information used for analysis consists of in-depth interviews conducted with main actors involved in the legislation process. Main actors identified through literature, newspaper reports and government records as well as through the snowballing technique for all three legislations were approached for appointment and voice-recorded interviews were conducted upon consent. In total, 31 interviews were conducted. Snowballing technique was also used where every interviewee was asked to mention people who they considered had played the most significant role in passing of the legislation. This helped not only identifying 
key players, in addition to those identified through review of literature, but also helped confirming the names included in the list. Interviewees belonged to three categories; those who lobbied for the bill outside the parliament, who supported it inside the parliament and the ones who were at the time in decision making positions in the concerned Government Ministries.

\section{8: COLLECTION OF DATA, RECORDING AND DOCUMENTATION}

The collection of primary data was done in person. The in-depth interviews were conducted during the first quarter of 2014 in cities of Lahore, Karachi and Islamabad. A total of 31 indepth interviews were conducted, 30 of which were completed, with the key actors involved in the legislative process. Of the total 30 interviews, 27 were conducted face-to-face, two were telephonic and one through Skype. Of the 27 face-to-face interviews, two respondents did not permit voice recording of their conservation and were, therefore, paper-based. One key respondent, due to his position at the time of fieldwork as the Chairman of the National Accountability Bureau did not agree for the interview even after multiple contacts. All in all, 26 interviews were voice recorded through face-to-face and Skype-based interviews, and two were paper-based and relied on interview notes. All interviews were digitally recorded and transferred to the central system and processed for transcription, categorisation and thematic grouping.

\section{9: STUDY TOOL}

The theoretical approach of 'regulatory conversation,' within the ambits of discourse analysis, proposed by Julia Black is triangulated with the proposed ideational framework of 
public policy and used as the framework for designing the study tools. ${ }^{43}$ Furthermore, based on the framework proposed by Mantzana et al for identification of different actors involved in the policy process, the designed tool was conducted with three groups of respondents, namely the policymakers [providers], the bureaucracy [controller], and the interest groups and lobbyists [supporters] who supported the selected legislation. ${ }^{44}$ The fourth category of end-users or public-at-large [acceptors] due to absence of their role in selected legislations. Similarly, the crosscutting category of 'detractors' or those who opposed the legislation was not studied because only successful legislative cases were selected for this research.

Three different sets of guidelines were developed, one each for acceptors, controllers and supporters, based on the framework of Julia Black and the proposed ideational framework. Each guideline consisted of five identical sections, namely pre-interpretation or interpretation, identity knowledge, power and contestation. The section in the guidelines on 'pre-interpretation/interpretation' studied how problem is represented in policy and to ascertain the conceptual premise or logic that underpin the same in its representation. The section on 'identity' assessed how different actors view individuals and organisations involved and how their identities are shaped in the public policy process. The section on 'knowledge' had the objective of highlighting the instrumental dimensions and the extent to which it is used in framing public policy solutions and the section on 'power' helped in ascertaining the extent to which power is exercised and composition of power, i.e. binary or fragmented, in forging and enacting public policy solution. The final section on 'contestation' explored how identities are shaped and positions jostled, between the actors involved, as well

\footnotetext{
${ }^{43}$ Black, J., "Regulatory Conversation," Journal of Law and Society, Vol. 29, No. 1 (2002): 163 - 96 ${ }^{44}$ Mantzana, V. et al., "Identifying Healthcare Actors Involved in the Adoption of Information System," European Journal of Information Systems, Vol. 16 (2007): 91 - 102
} 
as contestation of knowledge and power in influencing public policy (guidelines 1, 2, and 3 are annexed at the end of this research).

\subsection{0: ANALYSIS OF DATA AND TRIANGULATION}

Stake writes, "Triangulation is a form of confirmation and validation." requires making use of more than one data collection method as a strategy to increase the credibility or internal validity of research. ${ }^{46}$ The research has employed mix-methods research for data collection and conducted review of publish literature, assessment of parliamentary debates, minutes of the meetings, resolutions, analysis of media reporting including press releases and official statements and in-depth interviews to ensure triangulation of collected information.

The analysis of qualitative data, writes Gibbs, implies some kind of transformation...into a clear, understandable insightful and trustworthy analysis. ${ }^{47}$ Analysis of qualitative data usually starts with transcription of interviews, coding to demarcate segments therein and categorisation of responses in terms of similarities and common themes across the scripts. For this research, all recorded interviews and notes were transcribed and coded initially on the basis of the framework on 'regulatory conversation' and aligned with research questions. Once the coding was completed, responses were categorised and grouped as per major themes. Every major theme was grouped to draw conclusions. In the final stage of the

\footnotetext{
${ }^{45}$ Stake, Robert E., Qualitative Research: Studying How Things Work (New York: Guilford Press, 2010): 123

${ }^{46}$ Merriam, Sharan B. and Tisdel, Elizabeth J., Qualitative Research: A Guide to Design and Implementation (San Francisco: John Wiley \& Sons, 2015): 245

${ }^{47}$ Gibbs, Graham, R., Analysing Qualitative Date (London: Sage, 2007): 1
} 
analysis, major themes were organized as per the emerging pattern to correspond with the review and analysis of literature.

\subsection{1: LIMITATIONS OF THE STUDY}

Case study approach is not without its limitation, as is the case with any methodology. Most are concerned with the sensitivity, integrity and biasness of the investigator towards selection of the cases, which can only be addressed through researcher's self-awareness ${ }^{48}$. A main criticism, however, is concerned with the issue of generalizability of case study research and its lack of representativeness. ${ }^{49}$ Most of the mainstream efforts within the realm of postempiricist and post-positivist inquiry have introduced qualitative methods, which are regarded with scepticism by empiricist/rationalist methodologists. ${ }^{50}$ One of the main reasons for this scepticism, as Gobo writes, “concerns whether qualitative research results can be generalised, which is doubted not only because they are derived from only a few cases, but also because even where a larger number is studied these are generally selected without observing the rigorous criteria of statistical sampling theory." ${ }^{, 51}$ Paradoxically, as Mitchell rightly points out, "most social anthropological and a good deal of sociological theorizing has been founded upon case studies" or has been the product of exclusively theoretical inquiry. ${ }^{52}$

For theoretical generalisation, qualitative methodologists have taken up a variety of positions. The method of 'naturalistic generalisation', introduced by Robert Stake, is based on readers'

\footnotetext{
${ }^{48}$ Ibid, 52

${ }^{49}$ Hamel, J., "Case Study Methods," Qualitative Research Methods, Vol. 32 (Thousands Oaks CA: Sage, 1993): 23

${ }^{50}$ Yin R., 1988: 16

${ }^{51}$ Gobo, G., "Re-conceptualizing Generalization: Old Issues in a New Frame," in Pertti Alasuutari, Leonard Bickman, and Julia Brannen (eds.) The Sage Handbook of Social Research Methods (London: SAGE Publications, 2008): 193

${ }^{52}$ Mitchell, Clyde J., "Case and Situation Analysis," The Sociological Review, Vol. 31, No. 2 (1983): 188
} 
recognition of essential similarities to cases of interests to them for establishing the basis for generalisation. ${ }^{53}$ Stake writes "case studies are likely to continue to be popular because of their style and to be useful for exploration for those who search for explanatory laws. And, moreover, because of the universality and importance of experiential understanding, and because of their compatibility with such understanding, case studies can be expected to continue to have an epistemological advantage over other inquiry methods as a basis for naturalistic generalisation." ${ }^{54}$ The method of 'transferability,' introduced by Lincoln and Guba, conceives generalisation as a choice made by the reader of hypotheses to be transferrable "from situation to situation, depending on the degree of temporal and contextual similarity." ${ }^{, 55}$ Similar concepts of 'comparability' and 'translatability,' introduced by Goetz and LeCompte, where the former refers "to the degree to which components of a study including the units of analysis, concepts generated, population characteristics and settings are sufficiently well described and defined that other researchers can use the results of the study as a basis for comparison," and the latter includes the clear description one's theoretical stance and research techniques. ${ }^{56}$ In particular, the approach of 'analytic generalisation,' described by Robert Yin, which is generalisation to a theory of the phenomenon being studied, is relevant to the 'policy-as-discourse' methodology applied for this research. Yin summarises this approach that "to the extent that any study concerns itself with generalizing, case studies tend to generalise to other situations (on the basis of analytic claims), whereas surveys and other quantitative methods tend to generalise to populations (on the basis of

\footnotetext{
${ }^{53}$ Stake, Robert E., "The Case Study Method in Social Inquiry," Educational Researcher, Vol. 7, No. 2 (1978): $5-8$

${ }^{54}$ Ibid, 7

${ }^{55}$ Guba, Egon G., and Lincoln, Yvonna S., "Epistemological and methodological bases of naturalistic inquiry," Educational Communication and Technology Journal, Vol. 30 (1982): 238; also see: Lincoln, Yvonna S. and Guba, Egon G., Naturalistic Inquiry (London: SAGE Publications, 1978) ${ }^{56}$ Goetz, J.P. and LeCompte, Margaret D. Ethnography and Qualitative Design in Education Research (Orlando, FL, Academic Press, 1984): 228; and Schofield, Janet W., "Increasing the Generalizability of Qualitative Research," in Roger Gomm, Martyn Hammersley and Peter Foster (eds.) Case Study Method: Key Issues, Key Texts (London: SAGE Publications, 2000): 75
} 
statistic claims). ${ }^{57}$ The approach of 'analytic generalisation' is essentially derived from the concept of 'working hypothesis' proposed by Lee Cronbach. ${ }^{58}$ Cronbach writes, "When we give proper weight to local conditions, any generalisation is a working hypothesis, not a conclusion." 59 'Working hypothesis,' unlike quantitative methods, is not tested but used to gather data. In this sense, the claims presented in the previous section forms the 'working hypothesis' for this research in order to apply inductive reasoning to form conclusions about the process and outcomes of public policy. Generalisation is then the degree of transferability of conclusions from one context to another, based on the similarity of the two. Lincoln and Guba define this as fittingness - "the degree of congruence between sending and receiving contexts. If Context A and Context B are 'sufficiently' congruent, then working hypothesis from the sending originating context may applicable in the receiving context.",60

\subsection{2: CONCLUDING WORDS}

In contrast to the dominant influence of economics and its positivist scientific methodologies, the development of the field of policy studies, and its theorisation, requires a multidisciplinary methodological perspective, one that is strived in this chapter. ${ }^{61}$ The perspective of post-empiricists, who emphasise on the integration of normative and empirical modes of discourse, understand the discursive processes of confirmation and falsification "as complex activities involving a whole network of assumptions, hypotheses, competing theories, even research programmes, rather than singular hypotheses subject to direct

\footnotetext{
${ }^{57}$ Yin, Robert K., Application of Case Study Research (London: SAGE Publication, 2012): 19

${ }^{58}$ Cronbach, Lee L., "Beyond the Two Disciplines of Scientific Psychology," American Psychologist, Vol. 30, No. 2 (1975): $116-127$

${ }^{59}$ Ibid, 125

${ }^{60}$ Lincoln, Yvonna S., and Guba, Egon G., "The Only Generalization is: There is no Generalization," in Roger Gomm, Martyn Hammersley, and Peter Foster (eds.) Case Study Method (London: Sage Publications, 2000): 40

${ }^{61}$ Fischer F., 2003: 4
} 
empirical test." ${ }^{, 2}$ Policy-as-discourse analyses applied to this research see public policy process and its outcomes embedded in a web of social meanings produced and reproduced through discursive practices and shaped through socially interpreted understandings and meanings. ${ }^{63}$ This involves complex ideational processes whereby policymakers assemble and assess information and construct pictures of reality. ${ }^{64}$

\footnotetext{
${ }^{62}$ Ibid, 13

${ }^{63}$ Ibid

${ }^{64}$ Bell, S., "The Power of Ideas: The Ideational Shaping of the Structural Power of Business," International Studies Quarterly, Vol. 56 (2012): 671
} 


\begin{tabular}{|c|c|c|c|}
\hline Index & Reference Period & Score & Classification \\
\hline Vanhanen's Index of Democracy ${ }^{65}$ & 2014 & 9.83 & Democracy \\
\hline Bertelsmann Stiftung Transformation Index ${ }^{66}$ & 2016 & 3.7 & Hard-line Autocracy \\
\hline Democracy Ranking $^{67}$ & $2013-2014$ & 38.2 & Very Low \\
\hline Economist Intelligence Unit Democracy Index ${ }^{68}$ & 2015 & 4.4 & Hybrid Regime \\
\hline Freedom House's Freedom in the World ${ }^{69}$ & 2016 & 41 & Partly Free \\
\hline Polity IV IV $^{70}$ & 2015 & 7 & Democracy \\
\hline
\end{tabular}

\footnotetext{
${ }^{65}$ Access on August 26, 2016 from https://www.prio.org/Data/Governance/Vanhanens-index-ofdemocracy/

${ }^{66}$ Accessed on August 26, 2016 from http://www.bti-project.org/en/reports/country-reports/

${ }^{67}$ Accessed on August 26, 2016 from http://democracyranking.org/wordpress/rank/democracyranking-2015/

${ }^{68}$ Access on August 26, 2016 from http://www.eiu.com (registration required)

${ }^{69}$ Access on August 26, 2016 from https://freedomhouse.org/report/freedom-world/freedom-world2016

${ }^{70}$ Access on August 26, 2016 from http://www.systemicpeace.org/polityproject.html
} 


\begin{tabular}{|c|c|c|}
\hline Step & Approach & Purpose \\
\hline 1 & Desk Research & $\begin{array}{l}\text { To make a first chronology and come up with a first reading of } \\
\text { events. }\end{array}$ \\
\hline 2 & Helicopter Interviews & For an overview of the field. \\
\hline 3 & Document Analysis & $\begin{array}{l}\text { For structuring concepts, ideas and categorisations; employment of } \\
\text { storylines, metaphors for defining structuring discourses in the } \\
\text { discussion. }\end{array}$ \\
\hline 4 & $\begin{array}{l}\text { Interviews with key } \\
\text { players }\end{array}$ & $\begin{array}{l}\text { For generating more information on causal chains ('which led to } \\
\text { what'), and to get a better understanding of the meaning of } \\
\text { particular events to reconstruct the discourse from which an actor } \\
\text { approached the situation. }\end{array}$ \\
\hline 5 & Sites of argumentation & $\begin{array}{l}\text { To search for data to reconstruct the arguments used and to account } \\
\text { for the argumentative exchange. }\end{array}$ \\
\hline 6 & $\begin{array}{l}\text { Analyse for positioning } \\
\text { effects }\end{array}$ & $\begin{array}{l}\text { To analyse positioning on the level of persons, among institutions } \\
\text { or even nation-states. }\end{array}$ \\
\hline 7 & Identify key incidents & $\begin{array}{l}\text { To identify of key incidents that are essential to understand the } \\
\text { discursive dynamics in the chosen case. }\end{array}$ \\
\hline 8 & $\begin{array}{l}\text { Analysis of practices in } \\
\text { particular cases of } \\
\text { argumentation }\end{array}$ & $\begin{array}{l}\text { To go back to the data to see if the meaning of what is being said } \\
\text { can be related to the practices in which it was said. }\end{array}$ \\
\hline 9 & Interpretation & $\begin{array}{l}\text { For coming up with an account of the discursive structures within a } \\
\text { given discussion, as well as an interpretation of the practices, the } \\
\text { sites of production that were of importance in explaining a } \\
\text { particular course of events. }\end{array}$ \\
\hline 10 & $\begin{array}{l}\text { Second visit to key } \\
\text { actors }\end{array}$ & $\begin{array}{l}\text { For respondents to recognise some of the hidden structures of } \\
\text { language when confronted with the findings. }\end{array}$ \\
\hline
\end{tabular}

${ }^{71}$ Hajer, Maarten A., 2006: 73 


\section{IDEATIONAL INSTITUTIONALISM AND PUBLIC POLICY MAKING IN PAKISTAN}

\section{1: INTRODUCTION}

his chapter is mainly divided into three main sections each of which is devoted to
a particular social legislation passed during the five-year tenure of the Thirteenth
National Assembly of Pakistan from 2008 till 2013. As discussed in more detail in Chapter 5, the selection of the Thirteenth National Assembly for the purpose of this research is based on the fact that it is the first ever to have completed its five-year constitutional tenure and thus allowing a comprehensive legislative analysis. Also the three social legislations studied are the only ones enacted as separate acts of the parliament during the five-year tenure, in contrast to an amendment to existing legislation or the Penal Code. The selection of social legislations is to further challenge the theoretical premise used for this research to explore all three dimensions of ideational policy making, namely cognitive, normative and material.

The overarching methodological approach used is of "policy-as-discourse," as described in Chapter 4, to study how certain ideas have generated and impacted policy outcomes in the case of the three selected legislations. In particular, framework of "regulatory conversation" offered by Julia Black is applied for understanding the mechanism through which ideas have 
originated and affected policy outcomes. ${ }^{1}$ The analysis of public policy process and its outcomes have focused on three interrelated facets that constitute institutions and form the basis for ideas, namely 'text,' 'agency' and the 'structural context.' Analysis of the text [what is said] has provided interpretation of ideas as in social and inter-subjective production of meaning whereas agency [who said what to whom] had informed interactively acquired or constituted identities of different actors involved in the decision-making process. Inquiry into the structural context [where, when, how and why it was said] has explored processes by which meaning is assigned and disseminated and the ability of the actors in constructing agenda, conceptualising problems and rendering the uncertain certain. Structural context has also looked into the processes and its dispersion in construction of meaning and identities and configuration of power.

Discourse analysis is used to position the three selected legislations on three dimensions of the ideational framework, see Chapter 4, namely cognitive, normative and maternal dimensions of decision-making to test the basic claim that ideational institutionalism has the capacity to inform an endogenous account of complex institutional evolution, continuation, adaptation, and innovation. In precise, the analysis look into the strength of the three claims made in Chapter 4 that ideas, not only affect the course of the policy process but are also the basis of proposed public policy solutions and eventual outcomes and that policy decisions are based on an interplay of myriad of ideas that have cognitive, normative and material characteristics and that actors use ideas of various kinds to interpret and construct their situation shaping their interest, preferences and identities but their decisions are reflective more of a dominant set of ideas, either in the background or foreground of the policy debate.

\footnotetext{
${ }^{1}$ Black, J., "Regulatory Conversation,” Journal of Law and Society, Vol. 29, No. 1 (2002): 163 - 96
} 
Each of the three main sections that follow this introductory note is devoted to the particular legislation studied for the purpose of this research. They are arranged on similar lines; first the basic contours of the legislations are introduced followed by their normative justification. This is followed by in-depth study, through the help of existing literature, of ideational forces that have shaped the legislative outcomes as well as a timeline is constructed of major events to help trace the origin of ideas in respect to the studied legislations. This foundational analysis then sets the stage for studying the underlying ideational dimensions, through the help of in-depth interviews conducted with main actors involved in the legislative process, to further explore the three claims made for this research. The concluding section of this chapter corroborates the findings of this research with the key claims postulated for this research in Chapter-4.

\section{2: THE PROTECTION AGAINST HARASSMENT OF WOMEN AT THE WORKPLACE ACT, 2010}

On March 9, 2010, the then-President Asif Ali Zardari signed the Protection Against Harassment of Women at the Workplace Bill, 2010 making it a parliamentary act. At the signing ceremony, attended by some 100 women activists, parliamentarians and members from the civil society at the Presidency, the President remarked that the bill aims "at creating a working environment for women free from harassment, abuse and intimidation." 2 The National Assembly had first passed this bill unanimously on January 21, 2010 and later it was cleared by the Senate on February 26, 2010. The Act defines harassment as "any unwelcome sexual advance, request for sexual favours or other verbal or written communication or physical conduct of a sexual nature or sexually demeaning attitudes, causing interference

\footnotetext{
${ }^{2}$ Daily Dawn, “Zardari Signs Bill: Harassment of Women is Now a Crime,” March 10, 2010
} 
with work performance or creating an intimidating, hostile or offensive work environment, or the attempt to punish the complainant for refusal to comply to such a request or is made a condition for employment." 3 The Act requires, as stated in its "statement of objects and reasons,' "all public and private organisations to adopt an internal Code of Conduct and a complain/appeals mechanism aimed at establishing a safe working environment, free of intimidation and abuse, for all working women." 4 The Act requires all organisations to constitute an Inquiry Committee consisting of three members, with at least one woman member, to enquire into written complaints of harassment and examine evidence and submit its findings and recommendation to the Competent Authority designated by the management to impose major or minor penalties to the accused if found guilty. Minor penalties range from censure and withholding of promotion or increment to stoppage in career growth and recovery of the compensation payable to the complainant. Major penalties include reduction to a lower post, compulsory retirement, removal or dismissal from service, and imposition of fine. The Act makes District Courts as an Appellate Authority and also provides for an Ombudsman appointed by provincial and federal governments to whom complainant has the option to directly register a complaint. The Act includes a Code of Conduct for organisation for protection against harassment of women at the workplace. ${ }^{5}$ In addition to this Act, the legislation also contained amendments to the Pakistan Penal Code and the Criminal Procedure Code. This, as per Section 509 of the Pakistan Penal Code, has increased the punishment for the crime to imprisonment of up to three years or fine of Pakistani Rupees 500,000 or both.

\footnotetext{
${ }^{3}$ The Gazette of Pakistan, "The Protection Against Harassment of Women at the Workplace Act 2010," March 11, 2010

${ }^{4}$ Ibid

${ }^{5}$ Ibid, schedule
} 
Soon after passing of the bill, it was hailed as having potential to improve women's status and "good news" for women of Pakistan. ${ }^{6}$ Dawn, one of the leading English dailies published nationwide in Pakistan, while covering the story made the subheading that the country has “entered a new era on Tuesday when the president signed the Protection against Harassment of Women at Workplace Bill 2010 that is designed to provide a safe working environment for women." The Express Tribune, another English daily, while reporting on the launching of a book by Dr. Fouzia Saeed who was the main force behind passing of the bill commented, "The law [Protection Against Harassment of Women at the Workplace Act 2010] if implemented in true spirit can bring the scale [woman right to work] back to an evenly balanced position." ${ }^{8}$ The News, which has the largest circulation in Pakistan, termed it as "landmark legislation." All in all, general reception in media on passing of the bill into a parliamentary law was overwhelmingly positive.

The bill's normative and instrumental justifications are based on the argument that it banns a practice "which is rampant and largely socially accepted" in Pakistan and is a hindrance towards greater women participation in workforce. ${ }^{10}$ In their exploratory study on sexual harassment in Pakistani organisations, Ali and Kramar write "women commonly face inappropriate behaviour and harassment on the streets, in the workplace, and in public spaces." $" 11$ Their analysis reveal contextual nature of sexual harassment and shows culture playing an important role in shaping the issues and challenges of sexual harassment that

\footnotetext{
${ }^{6}$ Solberg, K. Elisabeth, "New Laws Improve Women's Health in Pakistan,” The Lancet, Vol. 375 (2010): 1956

${ }^{7}$ Daily Dawn, "Protection for Women," March 11, 2010

${ }^{8}$ Express Tribune, "For the Other Half: A Tale of A Decade-Long Fight Against Wolves," by Myra Iqbal, December 23, 2013

9 The News, "President Zardari Signs Women Bill into Law," by Myra Imran, March 10, 2010

${ }^{10}$ Solberg, K. Elisabeth, 2010: 1956

${ }^{11}$ Ali, F., and Kramar, R., "An Exploratory Study of Sexual Harassment in Pakistan Organizations," Asia Pacific Journal of Management, Vol. 32, No. 1 (2015): 236
} 
women face in the workplace. ${ }^{12}$ Riaz, while studying implementation mechanisms of the Act, supports this assertion and writes "up till now [before passing of the law], harassment was not considered a crime but only a social evil that was justified by blaming women for provoking it and no law specifically covered harassment at workplace." ${ }^{13}$ Existing research shows high levels of incidence of workplace harassment in Pakistan. It is claimed that as many as nine out of ten workingwomen in the public and private sectors in Pakistan experience some form of harassment in the workplace. ${ }^{14}$ A study conducted by Riaz shows $70 \%$ women being physically harassed by their colleagues through unwanted calls, emails and unwanted touching. ${ }^{15}$ A situational analysis conducted by Alliance Against Sexual Harassment in private and public-sector organisations in Pakistan found that almost $80 \%$ female employees face sexual harassment at the workplace. ${ }^{16}$ From an instrumental perspective, harassment at workplace is seen having negative impact on women's selfesteem, productivity and participation. ${ }^{17}$ It is seen as a violation of human rights and human dignity, which discourages women to continue working. ${ }^{18}$ It is considered as one of the biggest hurdles faced by workingwomen in Pakistan. ${ }^{19}$ On the basis, it is argued that the Act "will encourage more women, who tend to stay at home, financially dependent on their husband and relatives, to work." ${ }^{20}$ Statistics reveal that in Pakistan four out of every five women do not participate in the labour force and majority of those employed are in

\footnotetext{
${ }^{12}$ Ibid, 16

${ }^{13}$ Riaz, S., "Implementation Mechanism: Protection Against Harassment of Women at workplace," Hamdard Islamicus, Vol. 34, No. 2 (2013): 70

${ }^{14}$ Coomaraswamy, R., "Human Security and Gender Violence," Economic and Political Weekly, Vol. 40, No. 44/45 (2005): 4732

${ }^{15}$ Riaz, S., 2013: 72

${ }^{16}$ Brohi, N. and Akbar, Usman A. (eds.) Situational Analysis on Sexual Harassment at Work Place (Islamabad: AASHA, 2003): 16

${ }^{17}$ Riaz, S., 2013: 71

${ }^{18}$ Ukey, Krishnarao L., "Devils at Workplace: Women Employees Beware," International Journal of Human Resource Management, Vol. 3 (2013): 7

${ }^{19}$ Cassum, Laila A., "Verbal Violence at Work Place: A Reality from Pakistani Context," Journal of Nursing Education and Practice, Vol. 4, No. 8 (2014): 24

${ }^{20}$ Ibid
} 
unorganised sector, known for lacking in productivity, income stability and low security of employment. $^{21}$ The Act is seen as a progressive step forward for legal and economic empowerment of women in Pakistan by giving them better protection from sexual harassment at workplace. ${ }^{22}$ The role of the Alliance Against Sexual Harassment, a coalition of a handful of civil society organisations in Pakistan, and of its key member Dr. Fouzia Saeed, a social activists and gender expert, is widely recognised as the main driving force behind bringing this issue in the national discourse and getting the legislation passed by the National Assembly in $2010 .^{23}$ The following section traces the timeline that eventually led to the passing of this legislation in the context of Pakistan.

\subsection{1: IDEATIONAL FORCES BEHIND LEGISLATION AGAINST SEXUAL HARASSMENT OF WOMEN AT WORKPLACE}

The concept of sexual harassment at workplace from policy and legislative perspectives is fairly recent but as a discriminatory practice it has existed for many centuries. Segrave in his book entitled "the Sexual Harassment of Women in the Workplace, 1600 to 1993," looks at the history of the phenomenon and writes, "Sexual harassment cuts across time periods, countries, cultures and classes. ${ }^{24}$ Hass argues that sexual harassment must have existed since the times women entered the workplace and confronted with male dominance. ${ }^{25}$ Legal protection against sexual harassment was first developed in the United States in 70s. In United States, sexual harassment comes under sex discrimination as a violation of Title VII

\footnotetext{
${ }^{21}$ Pio, E. and Syed, J., "Our Bodies, Our Minds, Our Men: Working South Asian Women," Gender in Management: An International Journal, Vol. 28, No. 3 (2013): 142

${ }^{22}$ Ibid, 146

${ }^{23}$ See: Awan, Shehzadi Z., "Role of Civil Society in Empowering Pakistani Women," South Asian Studies, Vol. 27, No. 2 (2012): 439 - 458

${ }^{24}$ Segrave, K., The Sexual Harassment of Women in the Workplace, 1600 to 1993 (Jefferson NC: McFarland \& Company, 2013)

${ }^{25}$ Haas, Stans de, Sexual Harassment in a Male Dominated Workplace (Delft: Eburon Uitgeverij B.V., 2009): 1
} 
of the Civil Rights Act of 1964. The text of Civil Rights Act does not give definition of the term "sexual harassment" or even refers to it as a discriminatory practice. It was in 1980 when the Equal Opportunity Employment Commission, created for the enforcement and implementation of the Civil Rights Act in the United States, first defined the term and considered it as a violation of Title VII. As a result, interpretation of certain standards of legal protection from sexual harassment at workplace in United States has mainly evolved through case law. ${ }^{26}$ In United Kingdom too, tribunals started interpreting section 6(2)(b) of the Sex Discrimination Act 1975 since 1986 to provide legal protection to sexual harassment. ${ }^{27}$ The Section 6(2) if reads with sub-section (b) states, "It is unlawful for a person, in the case of a woman employed by him at an establishment in Great Britain, to discriminate against her by dismissing her, or subjecting her to any other detriment." ${ }^{28}$ At the European Union level, it was much later in 2002 with the Amendment to the Equal Treatment Directive of 1976, which aims at harmonising regulation of sexual harassment in Europe. ${ }^{29}$ It is thus safe to conclude that sexual harassment has been a widespread workplace phenomenon but as a legal issue it has only recently started evolving. ${ }^{30}$

United States was the first country to recognise sexual harassment at workplace as a legal problem requiring protection by law. ${ }^{31}$ This was in the backdrop of the broader social

\footnotetext{
${ }^{26}$ Ulvik, M., Protection from Sexual Harassment at the Workplace in the United States and What European Union Could Learn from it (Budapest: Central European University - Electronic Thesis and Dissertation, 2008): I

${ }^{27}$ Lockwood, G., Rosenthal, P. and Budjanovcanin, A., "Sexual Harassment Litigation in Britain: A Window on the Socially Irresponsible Workplace," Tamara Journal, Vol. 6, No. 4 (2007): 133

${ }^{28}$ Section 6(2)(b) of the Sex Discrimination Act 1975 of the United Kingdom

${ }^{29}$ Ibid

${ }^{30}$ Lockwood, G., Rosenthal, P. and Budjanovcanin, A., 2007: 132

${ }^{31}$ For details on how laws on sexual harassment at workplace in U.S. have formed over the year, see: Lee, Charlene H., Sexual Harassment of Women in the American Work Place, Executive Research Report S34 (Washington D.C.: The Industrial College of the Armed Forces, 1991)
} 
movement in the United States at the time. ${ }^{32}$ At the global level, however, ideational roots for legal protection of women against sexual harassment at workplace are traceable in the feminist movements, role of the United Nations, and its various agencies working on women's issues. ${ }^{33}$ In particular the second feminist movement of $1960 \mathrm{~s}$ and $1980 \mathrm{~s}$ and its continuation as in the third wave of feminism, which started in late 1980s and continuing to the present, are instrumental in institutionalizing the legislative needs for responding to women's human rights violations in general and sexual violence against women in particular. ${ }^{34}$ In literature and academic debates too, there emerged a broad-based agreement on the universality of sexual harassment and severity for policy and legal standards. ${ }^{35}$

At the global level, the Universal Declaration of Human Rights, which the UN General Assembly adopted on December 10, 1948, emerges as the most significant ideational force on principles of fundamental human rights and freedoms. The Article 23 of the Declaration states, "Everyone has the right to work, to free choice of employment, to just and favourable conditions of work and to protection against unemployment." The sub-clause 2 of the same Article further states, "Everyone, without any discrimination, has the right to equal pay for equal work." 36 Pakistan, in the United Nations General Assembly meeting, had voted in favour of the Convention. About ten years later in 1960 the International Labour Organisation, a specialised agency of the United Nations, brought in force its Convention 111

\footnotetext{
${ }^{32}$ Zippel, Kathrin S., The Politics of Sexual Harassment: A Comparative Study of the United States, the European Union, and Germany (Cambridge: Cambridge University Press, 2006): 42

${ }^{33}$ Prasad, K., "Women's Movement and Media Action: Paradoxes and Promises," in Kiran Prasad (ed.) Women and Media: Challenging Feminist Discourse (New Delhi: The Women Press, 2005): 213

${ }^{34}$ Bhatia, G., "Demystifying the Feminine Self," International Journal of Technological Exploration and Learning, Vol. 2, No. 6 (2013): 323

${ }^{35}$ Gruber, J. E., Smith, M., and Kauppinen-Toropainen, K., "Sexual Harassment Types and Severity: Linking Research and Policy," in Margaret S Stockdale (ed.) From Sexual Harassment in the Workplace: Perspectives, Frontiers, and Response Strategies, 151-173 (Thousand Oaks: Sage Publications, 1996): 151

${ }^{36}$ Article 23 of The Universal Declaration of Human Rights, retrieved from http://www.un.org/en/documents/udhr/index.shtml on June, 17, 2014
} 
concerning discrimination in respect of employment and occupation. Its preamble affirms that discrimination constitutes a violation of rights enunciated by the Universal Declaration of Human Rights. While the convention does not explicitly refer to sexual harassment as a form of discrimination but its broad definition is interpreted as such. The Article 1 of the Convention defines 'discrimination' as “any distinction, exclusion or preference made on the basis of race, colour, sex, religion, political opinion, national extraction or social origin, which has the effect of nullifying or impairing equality of opportunity or treatment in employment or occupation," which effectively covers sexual harassment as well. ${ }^{37}$ Pakistan ratified the Convention on January 24, 1961. On July 2, 1964 President Lyndon Johnson signed into law the Civil Rights Act wherein Title VII prohibits discrimination on the basis of race, colour, religion, sex and national origin. It is important to note, as Fraser highlights, women delegates and numerous international women's organisations were of the view that Commission on Human Rights has failed to recognise women's aspirations adequately and therefore an independent freestanding Commission is needed. ${ }^{38}$ The Commission on the Status of Women was thus established "with the aim to prepare recommendations and reports to the Council on promoting women's rights in political, economic, civil, social and educational fields. The Commission also makes recommendations to the Council on urgent problems requiring immediate attention in the field of women's rights." 39 The Commission, with the support of women's organisations and other NGOs and in the backdrop of feminist movement, was able to successfully lobby and adoption of the Convention on the Elimination of all Forms of Discrimination Against Women in in $1979 .{ }^{40}$ The Convention categorically declares that States should eliminate discrimination against women in the field of

\footnotetext{
${ }^{37}$ Article 1 of the ILO Discrimination Convention 111, retrieved from http://www.ilo.org/dyn/normlex/en/f?p=NORMLEXPUB:12100:0::NO::P12100_ILO_CODE:C111 on June 17, 2014

${ }^{38}$ Fraser, Arvonne S., "Becoming Human: The Origins and Development of Women's Human Rights," Human Rights Quarterly, Vol. 21, No. 4 (1999): 855

${ }^{39}$ United Nations Economic and Social Council, Resolution 11(II) of June 211946

${ }^{40}$ Fraser, Arvonne S., 1999: 855
} 
employment and "pursue by all appropriate means and without delay a policy of eliminating discrimination against women. ${ }^{, 41}$ In Article 1, the Convention defines discrimination against women as "any distinction, exclusion or restriction made on the basis of sex which has the effect or purpose of impairing or nullifying the recognition, enjoyment or exercise by women, irrespective of their marital status, on a basis of equality of men and women, of human rights and fundamental freedoms in the political, economic, social, cultural, civil or any other field." 42 The Convention, however, still not specifically touched upon the issue of sexual harassment at the workplace. It was in January 1992 when the Committee on the Elimination of Discrimination against Women, set up under the Convention, adopted a General Recommendation No. 19 on violence against women that defines what constituted sexual harassment at the workplace. In 1989, the Committee in its General Recommendation No. 12 had asked the State parties "that they should include in their periodic reports to the Committee information about...the legislation in force to protect women against the incidence of all kinds of violence in everyday life (including sexual violence, abuses in the family, sexual harassment at the work place etc.) ${ }^{, 43}$ However, it was the General Recommendation No. 19 when its Article 11 categorically stated, "Equality in employment can be seriously impaired when women are subjected to gender-specific violence, such as sexual harassment in the workplace," and also defined sexual harassment as "such unwelcome sexually determined behaviour as physical contact and advances, sexually coloured remarks, showing pornography and sexual demand, whether by words or actions. Such conduct can be humiliating and may constitute a health and safety problem; it is discriminatory when the woman has reasonable grounds to believe that her objection would

\footnotetext{
${ }^{41}$ Article 2 of the Convention on the Elimination of All Forms of Discrimination Against Women, 1979

${ }^{42}$ Article 1 of the Convention on the Elimination of All Forms of Discrimination Against Women, 1979

${ }^{43}$ Committee on the Elimination of Discrimination against Women, General Recommendation No. 12, passed in the Eighth Session, 1989
} 
disadvantage her in connection with her employment, including recruitment or promotion, or when it creates a hostile working environment." 44 Pakistan ratified the Convention on the Elimination of All Forms of Discrimination Against Women in 1996.

The role of the Commission on the Status of Women is crucial in not only developing norms in areas of concern to women but also focusing world attention on issues that particularly impact women. ${ }^{45}$ It was due to the Commission's role that resulted in treaties, declaration and programs of action in support of improving the status of women. ${ }^{46}$ For instance, the decade of 1976 - 1985 was designated as the United Nations Decade for Women. The General Assembly declared 1975 as the International Women's Year and the first World Conference on Women was held Mexico City. The final conference dedicated to women was held in 1995 in Beijing and launched the Beijing Declaration and Platform for Action, which is adopted by 18 countries, including Pakistan. ${ }^{47}$ The Platform for Action asked governments to “enact and enforce laws and introduce implementing measures...[for]...legal protection against sexual and racial harassment," as well as "develop workplace polices...[to]...regarding discriminatory working conditions and sexual harassment." ${ }^{48}$ It was around that time, as Aeberhard-Hodges writes, several countries started declaring sexual harassment at the workplace as a prohibited activities and implementing measure to curb the practice. ${ }^{49}$ By 1995, it is safe to conclude that sexual harassment at workplace started

\footnotetext{
${ }^{44}$ Committee on the Elimination of Discrimination against Women, General Recommendation No. 19, passed in the Eleventh Session, 1992

${ }^{45}$ Defeis, Elizabeth F., "The United Nations and Women - A Critique," William \& Mary Journal of Women and the Law, Vol. 17, No. 2 (2011): 397

${ }^{46}$ Ibid

${ }^{47}$ Ibid, 398

${ }^{48}$ The Fourth World Conference of Women, "Beijing Declaration and Platform for Action," held in Beijing from September 4 to 15, 1995: 78

${ }^{49}$ Aeberhard-Hodges, J., "Sexual Harassment in Employment: Recent Judicial and Arbitral Trends," International Labour Review, Vol. 135, No. 5 (2006): 501
} 
attracting full attention of the law with industrialised countries taking the lead and others were soon in pursuit. $^{50}$

However, the development in Pakistan in respect to legislation against sexual harassment at workplace followed a different trajectory than at the global level and had different triggers. Ali and Kramar argue that interpretation and implementation of sexual harassment policies may have been influenced by culturally ascribed gender roles in Muslim-majority countries. ${ }^{51}$ This is visible in legislative role of women organisations in Pakistan. Awan broadly divides upsurge in women organisation in Pakistan in three phases, first started in 1960s to demand for family laws, the second in 70s against women discriminatory laws and third in 1990s when it culminated into the global women rights movement and took inspiration from ideational forces working at the global level. ${ }^{52}$ Awan also gives account of legislations either supported or opposed by women organisations in Pakistan. Before the turn of the twenty-first century, women groups had supported only two laws, namely Muslim Personal Law of Sharia of 1948 and Muslim Family Law Ordinance of 1961, and had opposed the Hudood Ordinance of $1980 .{ }^{53}$ It was during the first decade of the twenty-first century when women organisation, alliances and groups advocated for several legislative reforms and policies. $^{54}$ Unlike western feminism, the movement in Pakistan started much later in 80 s and conflated gender, as Khan writes, "with issues of cultural identity and colonial subjugation." ${ }^{, 55}$ The women groups in Pakistan had galvanised under the banner of Women Action Forum to

\footnotetext{
${ }^{50}$ Ibid

${ }^{51}$ Ali, F., and Kramar, R., “An Exploratory Study of Sexual Harassment in Pakistani Organizations,” Asia Pacific Journal of Management, Vol. 32, No. 1 (2015): 229 - 249

${ }^{52}$ Awan, Shehzadi, Z., "Role of Civil Society in Empowering Pakistani Women," South Asian Studies, Vol. 27, No. 2 (2012): 441

${ }^{53}$ Ibid, $450-451$

${ }^{54}$ Ibid

${ }^{55}$ Khan, S., "The Struggle for the Rights of Women in Pakistan," Shahida Murtaza (ed.)

Understanding Women's Issues: A Feminist Standpoint, 184 - 199 (Saarbrücken: Lambert Academic Publications, 2012): 184
} 
oppose gender-discriminatory policies and laws of the military regime of the time. ${ }^{56}$ As women groups started asserted themselves, they appealed to the human rights approach to the status of women. ${ }^{57}$ During the last civilian rule in Pakistan [1988-1999], women groups and organisations gained further grounds and better aligned themselves to the global ideational currents on protection of women rights. Importantly, the burgeoning of civil society networks was all in the backdrop of General Zia's military rule of 1980s and in reaction to the implementation of his controversial policy of Islamisation. ${ }^{58}$ In order to gain political legitimacy and win-over the approval of the international community, General Pervez Musharraf [1999 - 2008] made considerable concessions during his 11-year military rule by opening up the public space. As the result, by the time the civilian rule returned during which several pro-women legislations were passed including the Protection of Women Against Sexual Harassment at the Workplace, there were already a burgeoning media environment and a vibrant civil society networks existing in Pakistan. ${ }^{59}$

Women representation in politics and in legislature was also unprecedented at the time when bill on Sexual Harassment at the Workplace was passed. ${ }^{60}$ The reforms made during the previous military regime of General Pervez Musharraf [1999 - 2008] had increased women representation in the parliament from $2 \%$ to $20 \%$. Shami considers it a "very bold and positive step that herald the beginning of a whole new chapter in the political participation of

\footnotetext{
${ }^{56}$ Ibid, 188

${ }^{57}$ Chumil, Marisa L., Rodriguez, Diana G., and Boyd, Michelle L., "The Struggle for Rights: Pakistani Muslim Women in Pakistan and how to Support Advocacy Efforts," PRAXIS, Vol. 9 (2009): 49

${ }^{58}$ Mustafa, B. and Brown, Katherine E., "The Taliban, Public Space and Terror in Pakistan," Eurasian Geography and Economics, 51.4 (2010): 504

${ }^{59}$ Yusuf, H. and Schoemaker, E., "The Media of Pakistan: Fostering Inclusion in a Fragile Democracy?” BBC Media Action Policy, Briefing 9, September 2013: 8

${ }^{60}$ Ali, Azra A., "Empowerment and Political Mobilization of Women in Pakistan: A Descriptive Discourse of Perspectives," Pakistan Journal of Social Sciences, Vol. 32, No. 1 (2012): 226
} 
women in Pakistan."61 This had raised expectations in civil society, including media, from the women parliamentarians to advance protection of women's rights through legislative measures. For instance, Shami writes, "it is hoped that women parliamentarians will rise above party affiliations and gravitate towards forming an "intra party bon" for jointly devising appropriate measures in support of women's rights. ${ }^{, 62}$ In a conference "Women Political Participation" organised by the Ministry of Women Development, President General Pervez Musharraf advocated for similar expectation and call upon all women parliamentarians to "become effective in legislation to ensure that no law detrimental to their rights and interests is passed." ${ }^{, 63}$ During the civilian rule of Pakistan's Peoples Party [2008 2013], the female representation in the national parliament stood at $22.5 \%$ and ranked fifth in the world. ${ }^{64}$ Zaka argues that international treaties, i.e. the Convention on the Elimination of All Forms of Discrimination Against Women, had an important impact on the legislative role of women parliamentarians as it provided them with normative resources to describe their actions in terms of moral and legal imperatives. ${ }^{65}$

It was in this backdrop that in 2001 the Alliance Against Sexual Harassment was formed, under the leadership of Dr. Fouzia Saeed, to advocate for needed policy reforms to address the issue of sexual harassment in Pakistan. ${ }^{66}$ While working with the United Nations Development Programme (UNDP) in Pakistan, Dr. Saeed herself had been a victim of sexual harassment. Dr. Saeed had joined UNDP in 1994 and in December 1997 she, along with ten other female colleagues, filed a complaint of widespread sexual harassment to the UN Head

\footnotetext{
${ }^{61}$ Sham, Asma A., "Political Empowerment of Women in Pakistan," Pakistan Vision, Vol. 10 No. 1 (2009): 146

${ }^{62}$ Ibid, 147

${ }^{63}$ Dawn Daily, "Women MPs Told to Fight for Rights: Musharraf Opens Moot," December 22, 2002

${ }^{64}$ Zaka, Muhammad Rashid M., "Role of Women Parliamentarians and Research Practices in Pakistan," Journal of Peace, Conflict \& Development, Vol. 19 (2012): 22

${ }^{65}$ Ibid, 24

${ }^{66}$ Solberg, Kristin E., "New Laws Could Improve Women's Health in Pakistan," World Report, Vol. 375 (2010): 1956
} 
Office in New York against a senior male co-worker. It was the first ever case filed in the UN system under the premise of sexual harassment. The case was decided in 1999 in favour of the complainants after a little over one year of deliberations. Dr. Saeed has provided a detailed account of her time in UNDP and events and incidents surrounding this case in her book "Working with Sharks." ${ }^{, 67}$ Dr. Saeed returned to Pakistan in 2001 and joined Action Aid, an international nongovernmental organisation as its Country Director. From the platform of Action Aid, Dr. Saeed established an Alliance Against Sexual Harassment (AASHA) along with five other likeminded local organisations, namely Working Women's Association, Islamabad Women's Welfare Agency, Bedari, Interactive Resource Center and Layers for Human Rights and Legal Aid. ${ }^{68}$ The primary reason to establish the Alliance was, as it states, "to ensure an effective response to sexual harassment, including the enactment of specific policies and laws and the establishment of institutions to deal with it." ${ }^{\text {69 }}$ The Alliance also decided to focus only on sexual harassment at workplace. ${ }^{70}$ On December 22,2001 , the Alliance organised its first public event with participation from different sections of the civil society including government officials and called it Assembly of Working Women "to mark the struggle around the issue of sexual harassment at workplace in Pakistan." ${ }^{, 71}$ On the recommendation of the then-Minister for Women Development, Social Welfare, and Special Education Dr. Attiya Inayatullah recommended the alliance to develop a "Code of Conduct" which private and public organisation could adopt it to their management policies. ${ }^{72}$ The code was developed in 2002 by the Alliance and by the end of 2006 some 300 private-sector

\footnotetext{
${ }^{67}$ Saeed, F., Working With Sharks: A Pakistani Woman's Story of Sexual Harassment in United Nations - From Personal Grievance to Public Law (McLean, VA: Advances Press, 2013)

${ }^{68}$ These details are extracted from AASHA's own publication: AASHA., The AASHA Experience: A Decade of Struggle Against Sexual Harassment in Pakistan (Islamabad: Mehergarh Research and Publications, 2011): 12

${ }^{69}$ Ibid, 13

${ }^{70}$ Ibid

${ }^{71}$ Ibid, 15

${ }^{72}$ Ibid, 16
} 
organisations had adopted the code voluntarily. ${ }^{73}$ From 2003, AASHA had started pursuing for amendments into the Civil Services Disciplinary Rules known as ESTA code (Civil Establishment Code) that were applied to the government employees. The proposed amendments would have added a definition of sexual harassment at workplace as explanation under Removal of Services Ordinance $2002 .{ }^{74}$ In 2008, however, the Alliance decided to pursue only a bill on instituting a policy against sexual harassment in every registered body accompanying with amendment to the Pakistan Penal Code 1860 as well as into the Code of Criminal Procedure 1898 to add a more comprehensive definition of sexual harassment. ${ }^{75}$ Through the support of selected parliamentarians, the members of AASHA positioned the proposed bills individually and collectively to parliamentarians and their leadership. ${ }^{76}$ On October 18, 2008, AASHA was able to present the proposed bills to the Minister of Women Development Sherry Rehman for the first time who took personal interest in the proposed bills and also rallied Ministry of Law and Ministry of Labour and Manpower. The Minister for Women Development also agreed to present the proposed legislations as government bills and on November 5, 2008 the bills were presented to the Cabinet. ${ }^{77}$ The bills, after being vetted by the Law Department, were approved by the Senate in February 2009, with the support gained by AASHA from Senator Mian Raza Rabbani, who was leader of the house, and Shahnaz Wazir Ali, who was advisor to the Prime Minister. Bills were presented to the National Assembly in April 2009 and marked to the two Parliamentary Committees on Law and Justice and Women Development. Finally, in January 2010 the amendment bills on the proposed legislation were once again presented to the Senate after being passed from the Parliament, and the Senate also cleared the bill in February 2010.

\footnotetext{
${ }^{73}$ Ibid, 38

${ }^{74}$ Ibid, 52

${ }^{75}$ Ibid

${ }^{76}$ Ibid, 55

${ }^{77}$ Ibid, 61
} 


\begin{tabular}{|c|c|}
\hline 1948 & $\begin{array}{l}\text { Pakistan was among the signatory countries of the Universal Declaration of Human Rights, } \\
\text { which was adopted on December } 10 \text { and categorically states, "Everyone, without any } \\
\text { discrimination, has the right to equal pay for equal work." }\end{array}$ \\
\hline 1960 & $\begin{array}{l}\text { International Labour Organisation, a specialised agency of the United Nations, brought in } \\
\text { force its Convention } 111 \text { concerning discrimination in respect of employment and occupation. }\end{array}$ \\
\hline 1970 & Convention on the Elimination of all Forms of Discrimination Against Women was passed \\
\hline 1992 & $\begin{array}{l}\text { Committee on the Elimination of Discrimination against Women adopted a General } \\
\text { Recommendation No. } 19 \text { on violence against women that defines what constituted sexual } \\
\text { harassment at the workplace. }\end{array}$ \\
\hline 1996 & $\begin{array}{l}\text { Pakistan ratified the Convention on the Elimination of All Forms of Discrimination Against } \\
\text { Women. }\end{array}$ \\
\hline 1997 & $\begin{array}{l}\text { In December } 1997 \text { eleven women working with UNDP in Islamabad filed a case to the UN } \\
\text { headquarters against a senior member of the management on the charge of sexual harassment. }\end{array}$ \\
\hline 1999 & $\begin{array}{l}\text { In August 1999, UN investigative panel found the accused to be guilty in four of the eleven } \\
\text { cases, one of them of Dr. Fouzia Saeed who later in } 2001 \text { formed an alliance to push for } \\
\text { legislation against sexual harassment at the workplace. }\end{array}$ \\
\hline 2001 & $\begin{array}{l}\text { The Alliance Against Sexual Harassment was formed in Pakistan organised with an objective } \\
\text { to ensure an effective response to sexual harassment at the workplace, including the enactment } \\
\text { of specific policies and laws and the establishment of institutions to deal with it. }\end{array}$ \\
\hline 2005 & $\begin{array}{l}\text { Pakistan submitted its combined Initial, Second and Third Periodic Reports on August 3,2005 } \\
\text { to the Committee on the Elimination of Discrimination against Women and claimed that } \\
\text { sexual harassment at the workplace could be said to be covered by Section } 294 \text { of the Pakistan } \\
\text { Penal Code "Whoever, to the annoyance of others, a) does any obscene act in any public place, } \\
\text { or b) sings, recites or utters any obscene songs, ballad or words, in or near any public place, } \\
\text { shall be punished with imprisonment of either description for a term which may extend to } \\
\text { three months, or with fine, or with both." The report also mentions "Ministry of Women } \\
\text { Development has initiated work on a Code of Conduct for Gender Justice at the Work Place. It } \\
\text { aims at creating environment free of harassment for workingwomen."78 }\end{array}$ \\
\hline
\end{tabular}

\footnotetext{
${ }^{78}$ Combined Initial, Second and Third Periodic Reports of Pakistan under Article 18 of the Convention on the Elimination of All Forms of Discrimination against Women, August 3, 2005: 122 $\& 127$
} 


\begin{tabular}{|l|l|}
\hline \multicolumn{2}{|l|}{ Table 8.1: } \\
Timeline to the law on protection of women against sexual harassment at workplace in Pakistan \\
\hline 2007 & $\begin{array}{l}\text { In its Concluding Observations, the Committee expressed "concern at the discrimination faced } \\
\text { by women in the formal employment" and urged "State party to ensure equal opportunities for } \\
\text { women." It also asked Pakistan to report on measures taken in this respect on "monitoring } \\
\text { mechanisms and remedies, and their impact on realising equal opportunities for women. }\end{array}$ \\
\hline 2008 & $\begin{array}{l}\text { AASHA completed drafting of the bills to institute anti-sexual harassment policy and } \\
\text { amendments to the Pakistan Penal Code 1860 and to the Code of Criminal Procedures } 1898 \text { to } \\
\text { add a more comprehensive definition of sexual harassment. }\end{array}$ \\
\hline 2010 & The National Assembly passed the bill unanimously on January 21, 2010 \\
\hline 2010 & The Senate of Pakistan cleared the bill for President's assent on February 26, 2010. \\
\hline 2010 & $\begin{array}{l}\text { On March 9, 2010, the then President Asif Ali Zardari signed the Protection Against } \\
\text { Harassment of Women at the Workplace Bill, 2010 making it a parliamentary act. }\end{array}$ \\
\hline
\end{tabular}

The preceding analysis show that the main ideational force behind the legislation against sexual harassment of women at the workplace in Pakistan was the Alliance Against Sexual Harassment, which was formed by Dr. Fouzia Saeed in 2001. At the global level, however, there was already well-established ideational foundation on rights of women and against discriminatory practices against women in employment, which helped AASHA to further propagate the proposed legislation among concerned government circles. In particular, increasing women representation in the legislature, together with strong women personalities in key ministries and parliamentary committees, further helped their cause.

A report published by Mehergarh, a non-profit organisation established and run by Dr. Fouzia Saeed after she resigned from Action Aid, summarises AASHA's efforts in getting the legislation on protection of women against sexual harassment passed through a comprehensive approach which included "mobilising labour unions, formal and informal groups of working women and networks from the private sector," and by helping

\footnotetext{
${ }^{79}$ Committee on the Elimination of Discrimination against Women, "Concluding Comments of the Committee on the Elimination of Discrimination against Women: Pakistan," June 11, 2007: 7
} 
"government and the media to understand their roles in furthering the cause," which culminated into a "strong support base among major stake holders." $" 80$ The formation of Alliance Against Sexual Harassment or AASHA as it comes to be known in later years appears to be the "first significant controversy" in the legislative process.

A publication of Mehergarh written from the perspective of AASHA provides a detail account of how the legislation was passed. ${ }^{81}$ In an opening chapter, the report states that "The primary reason to establish this Alliance of civil society actors was the recognition that joint efforts of an Alliance were needed, in order to ensure an effective response to sexual harassment, including the enactment of specific policies and laws..."82 It was in 2001 during the official launch of AASHA when demand for legislation against sexual harassment of women at workplace was made publically. However, as the report states, the focus in initial years by AASHA was on constituting an "anti-sexual harassment policy at work places," and then gradually "move on to brining about legislation on the issue." 83 It was not until 2007 when "the idea of advocating for a specific legislation was further pursued." 84 The point of "last significant controversy" comes in 2010 when the legislative bill on Protection Against Harassment of Women at the Workplace was signed into a law.

The Government of Pakistan, in its latest report to the Committee on the Elimination of All Forms of Discrimination against Women, proudly boast Protection Against Harassment of Women at the Workplace Act and amendments made to Pakistan Penal Code 1860 by adding a clear definition of sexual harassment and setting punishment for such a crime to up to 3

\footnotetext{
${ }^{80}$ Ahmad, S., Leaders of Change: Drawing Lessons from Case Studies of Organizations with AntiSexual Harassment Policies (Islamabad: Mehergarh, 2010): C

${ }^{81}$ Hussain, M. and Ali, K., The AASHA Experience: A Decade of Struggle Against Sexual Harassment in Pakistan (Islamabad: Mehergarh, 2011)

${ }^{82}$ Ibid, 13

${ }^{83}$ Ibid

${ }^{84}$ Ibid, 34
} 
years imprisonment and/or fine of up to Rupees 500,000 as "major achievements." 85 The report further states that this is "in adherence with the Universal Declaration of Human Rights, CEDAW and ILO Conventions 100 and 111 on workers' rights and in accordance with the principles of Islam." 86

\subsection{2: UNDERLYING IDEATIONAL DIMENSIONS TO THE LEGISLATION ON SEXUAL HARASSMENT}

In this section, ideational dimensions are further elucidated that became the basis for the passing of the Protection Against Harassment of Women at the Workplace Act in 2010. This section is primarily based on the in-depth interviews conducted with the main actors involved in the legislative process. A total of 10 in-depth interviews were conducted for this particular legislation, three of which were conducted with the female parliamentarians of the time who had activity pursued the bill inside the parliament. Five interviews were conducted with the members of the Alliance Against Sexual Harassment, including of Dr. Fauzia Saeed, and the remaining two were conducted with the heads of Human Rights Commission and the United Nations Women Organisation in Pakistan which had provided further impetus to the legislation from the perspective of women's rights (see table 8.5 at the end of this chapter for further details).

Maliha Hussain, who's sister of Dr. Fauzia Saeed and one of the founding members of AASHA and presently heading Mehergarh which had later become the secretariat office for the Alliance, confirms that the idea of such a legislation originated when Dr. Fauzia Saeed

\footnotetext{
${ }^{85}$ Fourth Periodic Reports of Pakistan under Article 18 of the Convention on the Elimination of All Forms of Discrimination against Women, September 24, 2011: 26

${ }^{86}$ Ibid, 43
} 
along with 10 other female staff of UNDP won a case of sexual harassment against a senior male colleague:

"After having won the case, they decided to do something so that it's not this difficult for other women who are working in offices and they formed an Alliance in 2001...” [Maliha Hussain, Director, Mehergarh]

Dr. Fauzia Saeed, in her written interview, agreed that the main impetus for her to press for such legislation in Pakistan was because of her experience at the UNDP:

"When I reflected after our UNDP case was concluded, then I had discussions with the initial core members of AASHA (to be). In those discussions we were clear that without a policy we women in the case of UNDP could not have achieved what we did, regardless of how much courage it needed. Having provisions in the system was a must. We started out with wanting an anti sexual harassment policy in the offices. Acknowledging that eventually we would need the backing of the law and we need many steps to cover before then we put it in our long-term objectives at the time we were conceiving AASHA. We decided that policy will be the first target and later we would need a law.” [Dr. Fauzia Saeed, Founding Member AASHA and currently the Executive Director of Lok Virsa - Pakistan National Institute for Folk and Traditional Heritage]

I A Rehman confirms, who is the Chairman of Human Rights Commission of Pakistan and played a very influential role in rallying the politicians from the ruling party behind the proposed legislation, confirms that Dr. Fauzia Saeed had brought likeminded organisations 
and individuals from her network to advocate for legislation against women harassment at the workplace:

\begin{abstract}
"One of our colleagues Fauzia Saeed had been agitating against sexual harassment for many years and we were all concerned that some thing needs to be done and then came AASHA." [I A Rehman, Chairperson, Human Rights Commission of Pakistan]
\end{abstract}

Once Dr. Fauzia Saeed had established the Alliance Against Sexual Harassment or AASHA, it formed into a central identity for the movement to legislate around protection of women from workplace harassment, as Maliha Husain mentions:

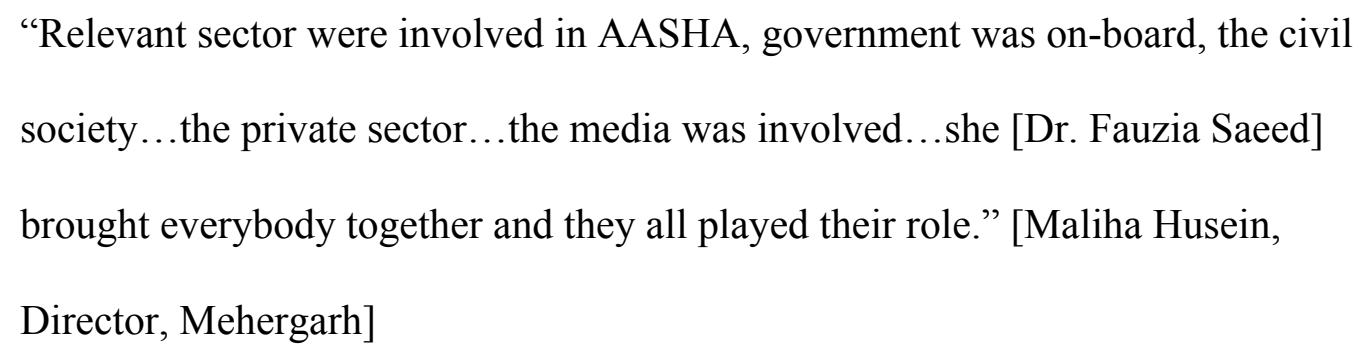

Female politicians, who later formed a strong caucus within the assembly to lobby for this bill, were also first introduced on this subject from the legislative perspective by AASHA. Dr. Attiya Inayatullah, who was the Minister for Women Development at the time when AASHA was launched and had attended the inaugural meeting recalls:

“In 2001, AASHA gathered a few organisation under one platform and started working against workplace harassment of women.” [Attiya Inayatullah, Former Minister for Women Development] 
Ms. Bushra Gohar, who was the Chair of the National Assembly's Standing Committee on Women's Development at the time when bill was passed and was also member of the women caucus who supported this bill, also mentions the same:

"It first came out of civil society's movement and I was part of it. AASHA coalition comes to my mind but there were so many people involved, especially women parliamentarians, women caucus and the Speaker Fehmida Mirza were all very active in having this legislation passed." [Bushra Gohar, Chair, National Assembly's Standing Committee on Women's Development]

Majority of those interviewed cited normative reasons for which the legislation was required.

"This is one of the most common forms of violence in Pakistan...and there was no law on this. There was definitely a pressure of CEDAW on government too that we used in our favour, we have signed and ratified these conventions and it is obligatory on us. And this international pressure does work." [Saleem Malik, Founding Member, AASHA]

"We spent 10 years establishing this fact that women harassment is actually a crime.” [Muhammad Waseem, Founding Member AASHA]

"This question had evolved that this whole issue of sexual harassment of women at workshop could only dealt with some legislation and by establishing forums where these misbehaviours could be dealt with and responsible people 
are taken to the task." [I A Rehman, Chairman, Human Rights Commission of Pakistan]

A few, however, did mention instrumental need for such legislation.

\begin{abstract}
"The whole issue of economic empowerment [of women] is linked with this subject and therefore I consider it a very important act.” [Fauzia Tariq, Representative UN Women]
\end{abstract}

"More than 300 organisations had adopted the code of conduct before the law was passed...and where the management was progressive and they were willing to make their work environment more dignified for women and eradicate this issue, there it worked beautifully. Attock Refinery Limited is an example, their induction of women went up by $8 \%$. . [Maliha Husein, Director, Mehergarh]

There is a general consensus among all the actors interviewed that this bill would have not passed had it not been the government of Pakistan's People Party at the time.

"The advantage with Pakistan Peoples Party is its membership of liberals and importance given to women issues, and this is why the government of the time run by Pakistan People Party was most suitable to have passed this legislation." [Saleem Malik, Founding Member, AASHA]

"While we started in 2001, the 2008 Government was more responsive to this bill.” [Muhammad Waseem, Founding Member AASHA] 
"Other parties did not have women rights on their agenda, so had it not been Peoples Party's government it would have been not possible...they were willing to listen to issues concerning to women." [I A Rehman, Chairperson, Human Rights Commission of Pakistan]

"It could have only been managed during Pakistan Peoples Party's government." [Attiya Inayatullah, Former Minister for Women Development]

"Pakistan Peoples Party did give a lot of space to women issues, and their coalition partner, like Awami National Party in Khyber Pakhtunkhwa were very progressive, so Pakistan Peoples Party should be given credit we could see that Speaker of Assembly was women and many Chairs of the standing committees were also women...so Pakistan Peoples Party when ever it is in the government it provides a lot of space to women.” [Bushra Gohar, Chairperson, National Assembly's Standing Committee on Women's Development]

"In 2010, you had a democratic government and a strong caucus of women parliamentarians and if you look back from 2008 to next five year there were lot of pro-women bills passed." [Fauzia Tariq, Representative, UN Women]

There was also an agreement that the women rights movement in general had also helped this legislation by creating an overall supportive environment. 
"This did not happen overnight... if you see women movement in Pakistan you can trace it back to 1947 ... and to the 1979 Women's Convention.... and the whole leftist movement of the time...but the turning point was 1994 when the Beijing Conference took place and all these movements culminated into an action plan for state parties." [Fauzia Tariq, Representative, UN Women]

"There has been a civil society movement in Pakistan for quite sometime and there have been many organisations that have come out on the streets that have raised this issue, so you can certainly say that there was this environment created that women are given their rights." [Attiya Inayatullah, Former Minister for Women Development]

"It has [policy and legislative environment for women issues] improved in some ways. We got seven laws passed in the last government, which is a big breakthrough. At least the trend that doing something for women is a good thing and doesn't always have to be seen as controversial was established." [Dr. Fauzia Saeed, Founding Member AASHA and currently the Executive Director of Lok Virsa - Pakistan National Institute for Folk and Traditional Heritage]

Passing of the legislation against harassment of women at the workplace was not without opposition.

"It's difficult to have legislation passed on women issues in Pakistan because it is instantly labelled by some circles as Western Agenda and something that is against the tenants of Islam” [Saleem Malik, Founding Member, AASHA] 
"In the senate, we are told that people from the government, people may be like Babar Awan, instigated the religious political parties to turn against it because when the process started they were on-board, and they said things like that these women from NGOs want freedom and they are already doing bad things and when you pass this law they will use it do more bad things." [Maliha Husein, Director, Mehergarh]

"We knew religious parties are not going to vote in favour of this bill but we still talked to them. They are of the opinion that women should stay at home and such issues will only arise if they step outside their homes, and it is the duty of Men to be the breadwinner." [Saleem Malik, Founding Member, AASHA]

"Our society is conservative and patriarchal, if you work in such an environment then it becomes difficult as religion is dragged into such matters for no apparent reason to obstruct the process only." [I A Rehman, Chairperson, Human Rights Commission of Pakistan]

This contestation was managed through multiple means and strategies, for instance the demand for the legislation was put, for some years, on the backburner till the time a more supportive environment was available. In addition, key members from the ruling party as well as from coalition partners were brought on board and a policy of cooperation was used than confrontation to deflect disagreements. 
"Fauzia approached me and told me that I have this bill, code of conduct and we have formed this committee and we ask you to pass this as a law, I told Fauzia...that at this point in time it might not be conducive to put forward as there is already a heated debate going around other pro-women laws and if I take it further then first no one would agree to it so I suggested her to keep this issue alive and start talking about this." [Attiya Inayatullah, Former Minister for Women Development]

"You have to have powerful people with you or otherwise your bill will be torn into pieces...in this bill Shahnaz Wazir Ali, Raza Rabbani and Sherry Rehman from Peoples Party were very supportive.” [Saleem Malik, Founding Member,

\section{AASHA]}

"Several of our civil society organisations who say they have been working on legislation have stuck to big hotel seminars and protest rallies on the streets. AASHA members started doing lobbying inside the parliament building and with individuals on one to one basis. [Dr. Fauzia Saeed, Founding Member AASHA and currently the Executive Director of Lok Virsa - Pakistan National Institute for Folk and Traditional Heritage]

While efforts were made to make the legislative process participatory and inclusive, it nevertheless remained activists' and experts' driven law.

"Laws are made by experts but it would be wrong to say that people's aspirations were not made part of it; a series of consultations were undertaken 
with a cross-section of the society for their inputs." [Muhammad Waseem, Founding Member, AASHA]

"In terms of having this issue positioned in the mainstream, I don't think Dr. Fauzia was the key factor, the organisation with whom she had worked all had raised voices on women issues, so I think it wasn't because of one individual.” [Fauzia Tariq, Representative, UN Women]

\begin{abstract}
"There were lot of people who were involved in this process...women and men... and because of this lot of issues are filtered and don't' become contentious" [I A Rehman, Chairperson, Human Rights Commission of Pakistan]
\end{abstract}

While the impetus for this legislation was the result of one particular incident of sexual harassment inside Pakistan, similar legislations and policies from neighbouring countries and other regions were studied and incorporated in developing this law. UN Agencies and other bilateral donors also provided technical and monetary support towards drafting the legislation.

"For sexual harassment, I have been studying every country that has a policy or a legislation in place, i.e. Commission on Equal Opportunity in USA and all the cases in detail that were tried; Malaysia, Philippines and others. Once I had completed the initial draft we did provincial consultation for improvements and also for building the ownership of a broad based stakeholder group. At that time I remember sending it to ILO in Geneva and their team of lawyers studied it and 
gave comments." [Dr. Fauzia Saeed, Founding Member AASHA and currently the Executive Director of Lok Virsa - Pakistan National Institute for Folk and Traditional Heritage]

"Similar laws from other countries were studied, for instance the law in India was referred that was passed after the order of the Supreme Court, literature from European countries was referred, and especially to define what constitute sexual harassment.” [Saleem Malik, Founding Member, AASHA]

"Absolutely, best practices were studied and we provided a lot of support to AASHA and Mehergarh.” [Fauzia Tariq, Representative, UN Women]

"DFID had supported this, European Union provided help, Action Aid was with us and UN Women was also part of it. It was only made successful because it had a very inclusive approached and involved a lot of partners." [Muhammad Waseem, Founding Member, AASHA]

From the preceding discussion, the central role of Dr. Fauzia Saeed is confirmed and her own impetus of pressing for such legislation due to sexual harassment she herself experienced at the UNDP. Politicians interviewed for this research also confirm of being orientated on the need for legislation on prevention of sexual harassment at the workplace by AASHA, which was led by Dr. Fauzia Saeed herself. Generally, respondents provided normative reasoning on the need for this legislation. However, especially members of AASHA also sighted instrumental benefits, which the legislation could have brought. Material dimension becomes apparent when respondents generally agreed that the government of Pakistan Peoples Party of 
the time and expectation from sizeable representation of women in the parliament to legislate on women issues played a significant role. The findings also confirm public representation and inclusiveness in shaping of policy agenda originating outside the legislature through AASHA and the role the Alliance played in bringing diverse voices on a single platform. In contrast, the contestation over the formulation of the policy agenda rested in the legislature with religio-political parties because of which some concessions were also made to the original policy proposal.

\section{3: THE TRANSPLANTATION OF HUMAN ORGANS AND TISSUES ACT, 2009}

Transplantation and Human Organs and Tissue Act, 2009 received the assent of the then President Asif Ali Zardari on March 17, 2010 and became and act of the parliament. The Act provides for the regulation, removal, storage and transplantation of human organs and tissues for therapeutic purposes. ${ }^{87}$ Article 3 of the Act defines a living donor as someone who is not less than eighteen years of age and legally related, close blood relative and who "may during his life-time voluntarily donate any organ or tissue of his body to any other living person genetically... and the donation of organ or part or tissue by such person for therapeutic purpose." 88 The same article further explained "close blood relative" being parent, son, daughter, sister, brother and spouse provided that transplantation is voluntary, genuinely motivated and without any duress or coercion. Only in case of non-availability of a donor can another person who is not a "close blood relative" donate a body organ if it is voluntary. The Act also provided for donation of human organs or tissues after death from donors who authorised this in writing or from unclaimed brain dead hospitalised patient after 24-hour

\footnotetext{
${ }^{87}$ The Gazette of Pakistan, "The Transplantation of Human Organs and Tissue Act, 2009," March 18, 2010

${ }^{88}$ Ibid, Article 3
} 
“intense search" for relatives. ${ }^{89}$ Article 5 of the Act prescribed an Evaluation Committee to be "established for every medical institution and hospital where at least twenty five transplants are being carried out annually," to "ensure that no organ or tissue is retrieved from non-related living donors without the prior approval" and for determining "brain death of a person; propriety of removal of a human organ from any living person and fitness or otherwise for transplantation of a human organ into any other body." 90 The Act also prescribes constitutions of a Monitoring Authority to recommend a "list of medical institutions and hospitals as recognised medical institutions and hospitals for practice of operative surgery in transplantation of human organs and tissues." 91 The Act gives description of the responsibilities of the Monitoring Committee as "monitor transplantation and enforce prescribed standards for recognised medical institutions and hospitals," as well as "investigate and hold inquiry into the allegations of breach of any provision of this Act," and “inspect recognised medical institutions and hospitals for examination of quality of transplantation, follow up medical care of donor and recipient and any other matter ancillary thereto and also periodically inspect institutions wishing to be recognised." The Act prescribes punishment for removal of human organ without authority "be punished with imprisonment for a term which may extend to ten years and with fine which may extend to one million rupees. ${ }^{, 92}$ For commercial dealing in human organs, the Act prescribes the same punishment. ${ }^{93}$ The Act also prescribes punishment for offenses by companies payable by fine as well as for the contravention of any other provision "with imprisonment for a term which may extend to three years or with fine, which may extend to three hundred thousand rupees or with both." 94

\footnotetext{
${ }^{89}$ Ibid, Article 4

${ }^{90}$ Ibid, Article 5

${ }^{91}$ Ibid, Article 6

${ }^{92}$ Ibid, Article 10

${ }^{93}$ Ibid, Article 11

${ }^{94}$ Ibid, Article 12 \& 13
} 
Pakistani media, print and broadcast, in general hailed and commended passing of the legislation. Dawn, an English language daily, termed the law as "landmark." The then President Asif Ali Zardari announced donation of his body organs and said, "Pakistan was singled out in the world community because of the notorious trade of organ transplant and now parliament and doctors should create awareness about the issue among the masses." 95 The Nation, another English daily, hailed approval of the Bill from both the Houses when Senate of Pakistan unanimously adopted the Bill on Wednesday February 10, $2010 .{ }^{96}$ The Chairman of the National Assembly's Health Committee, Dr. Nadeem Ahsan named Professor Dr. Adibul Hassan Rizvi, Director of the Sindh Institute of Urology and Transplantation (SIUT), as the main driving force behind passing of the legislation and said "his charismatic personality has also played a vital role in parliament to approve the bill." The role of Professor Dr. Adibul Hassan Rizvi is discussed in more detail in the next section but there is broad agreement that without his commitment passing of this legislation would not have been possible. So much so, a few month later when the President Asif Ali Zardari on a formal ceremony of signing a card stating that he would donate seventeen organs from his body also announced nominating Dr Adibul Hassan Rizvi for Nobel Peace Prize in recognition of his services in the field of organ transplant. ${ }^{98}$ The Sindh Institute of Urology and Transplantation is regarded as a prestigious research and medical organisation based in Karachi, which under the leadership of Dr. Adibul Hassan Rizvi paved the way for the regulation. The Institute provided necessary research, increased public knowledge, and brought religious leaders on-board from various schools of thought to declare that organ

\footnotetext{
${ }^{95}$ Daily Dawn, "Organ Transplant Bill Signed into Law," March 18, 2010

${ }^{96}$ Daily Nation, "Approval of Human Organ and Tissue Transplant Bill Hailed, February 14, 2010

${ }^{97}$ Ibid

${ }^{98}$ Daily Dawn, "Dr. Abid to be Nominated for Nobel, Says Zardari,” July 23, 2010
} 
donation is allowed in Islam. ${ }^{99}$ The campaign spanned over a period of 20 years and received support from the World Health Organisation and International Transplantation Society, Transplantation Society of Pakistan (TSP), Pakistan Society of Nephrology (PSN) and Pakistan Association of Urological Surgeons (PAUS) of Centre for Biomedical Ethics and Culture.

By 2007 Pakistan had become one of the leading kidney markets because of the availability of willing organ donors. A major motivating factor, writes Akhtar and Bari was poverty, "which induces the underprivileged to proffer their organs to the marketplace." ${ }^{\prime 100}$ They further argue that by engaging kidney brokers, private hospitals had commercialised the milieu and started exploiting the poor for profit which needed response from administration in Pakistan to assuage the predicament of the deprived in curtailing unethical kidney trade. ${ }^{101}$ In absence of government oversight and any meaningful regulation, Akhtar writes, Pakistan had become a major source for kidney transplantation where a minimum of 4,000 unethical kidney allo-transplantations were taking place annually which accounted $20 \%$ of illegal allografts worldwide. ${ }^{102}$ Kazim writes that among the common feature of commercialisation of human organ trade in Pakistan was absence of postoperative care to donor and giving only a fraction of amount that the recipient paid for transplant surgery. ${ }^{103}$ It was reported that clinics in Pakistan were charging on average US\$40,000 from organ recipient, whereas a

\footnotetext{
${ }^{99}$ Mustafa, Z., "Remembering Naveed Anwar,” Daily Dawn, March 20, 2012

${ }^{100}$ Akhtar, F., and Bari, Omar H., "Living-Unrelated Kidney Selling in Pakistan: Can Organ Transplantation Law and Social Action Create a New Model for Developing Countries?" World Medical and Health Policy, Vol. 2, No. 2 (2010): 133

${ }^{101}$ Ibid

${ }^{102}$ Akhtar, F., "Organ Transplantation Law in Pakistan to Curb Kidney Trade: Chance for Global Reflection," NDT Plus, Vol. 2 (2008): 128

${ }^{103}$ Kazim, Syed F., "Organ Donation Law in Pakistan: An Overview of the Current Situation," Journal of Pakistan Medical Association, Vol. 58, No. 2 (2008): 100
} 
donor was getting from US\$ 1,500 to US\$ 2,000. ${ }^{104}$ Unlike the Protection Against

Harassment of Women at the Workplace Bill, justifications for a law to regulate organ transplantation was not mainly based on normative appeals. Pakistan did not have any transplant registry nor did it have a donor card system. There was no law or regulation that could set minimum standards to the practice of organ transplantation as well as prescribed criteria for transplant institutions for obtaining license if they wished to perform organ transplantation. Pakistan also did not have any law on cadaveric donor.

\subsection{1: IDEATIONAL FORCES BEHIND ORGAN TRANSPLANTATION LAW IN}

\section{PAKISTAN}

Experimental studies on human organ transplantation had started early in the twentieth century. ${ }^{105}$ In 1954, the first successful kidney transplantation was performed. ${ }^{106}$ It has been now more than five decade since the practice of human organ transplantation emerged on the global stage. ${ }^{107}$ Human organ transplantation is now considered a lifesaving therapy but limited due to organ shortage. ${ }^{108}$ With the knowledge that transplantation can be life saving, writes Pesavento, not only there has been an ever-enlarging wait list for a deceased donor, live donor organ transplantation has also surged to fill the void. ${ }^{109}$ Yet, there is a dearth of both living and cadaveric grafts and the shortage exists in the donation of both lifesaving and

\footnotetext{
${ }^{104}$ Garwood, P., "Dilemma Over Live-Donor Transplantation," Bulletin of the World Health Organization, Vol. 85 (2007): 5 - 6

${ }^{105}$ Karlberg, I. and Schersten, T., "Human Organ Transplantation," World Health Forum, Vol. 10 (1989): 228

${ }^{106}$ Ibid

${ }^{107}$ Ashraf, O., Ali, S., Ali, Sumbul A., Ali, H., Alam, M., Ali, A., and Ali, Talaha M., "Attitude Toward Organ Donation: A Survey in Pakistan," Artificial Organs, Vol. 29, No. 11 (2005): 899 ${ }^{108}$ Pesavento, Todd E., "Kidney Transplantation in the Context of Renal Replacement Therapy," Clinical Journal of the American Society of Nephrology, Vol. 4 (2009): 2035

${ }^{109}$ Ibid, 2037
} 
non-lifesaving grafts. ${ }^{110}$ With human organ transplantation emerging as a preferred treatment along with improved survival, this resulted in increase in demand for human organs. As legislation in western countries restricted organ donation to living related or cadaveric donation, people from across the world turned to countries that did not have legislation or enforcement of such legislation supervising the transplant practice. Organ transplantation in countries like Pakistan became heavily commercialised and transformed into an illegal trade. $^{111}$

In Pakistan, recounts Dr. Rizvi, rental transplantation started in 1979 from a living related donor and from about 50 transplantations a year it rose to more than 500 by late $1990 \mathrm{~s} .{ }^{112}$ In absence of a deceased donor program coupled with shortage of organs and improvement in transplant expertise, Dr. Rizvi argues, led to unrelated commercial transplants with 1,000 transplants a year performed for transplant tourists alone, mostly in private facilities, by 2005. ${ }^{113}$ Dr. Rizvi argues that before Pakistan, India was the main hub for transplantation trade and tourism but it legislated against this practice in 1994 that deflected prospective recipients to Pakistan. ${ }^{114}$ Dr. Rizvi had started his medical career as a young urologist in 1972 in an eight-bedded department of genitourinary surgery in a government's Civil Hospital in Karachi. In 1991, the department was given the status of an Institute with financial and functional autonomy through an Act of the Assembly and named The Sindh Institute of

\footnotetext{
${ }^{110}$ Ashraf, O., Ali, S., Ali, Sumbul A., Ali, H., Alam, M., Ali, A., and Ali, Talaha M., 2005: 899

${ }^{111}$ Ilyas, M., Alam, M. and Ahmad, H., "The Islamic Perspective of Organ Donation in Pakistan," Saudi Journal of Kidney Diseases and Transplantation, Vol. 20, No. 1 (2009): 154

${ }^{112}$ Rizvi, Adibul H., "Living Donor Kidney Transplantation in Pakistan," Annals of Transplantation, Vol. 14, No. 1: (2009): 18

${ }^{113}$ Ibid

${ }^{114}$ Rizvi, Adibul H., Naqvi, S., Zafar, M. N., Hussain, Z., Hashmi, A., Akhtar, F. Hussain, M. and Ahmed, E., "Pakistan Abolishes Kidney Market and Ushers in New Era of Ethical Transplantation," International Journal of Organ Transplantation Medicine, Vol. 1, No. 4 (2010): 193
} 
Urology and Transplantation. ${ }^{115}$ The Institute in 1986 had already started a programme for free dialysis and transplantation. Dr. Rizvi explains that this programme was based on a model of "community/government partnership where dialysis and transplantation were integrated and all services were offered free of cost with life-long follow-up and medication." 116 The Institute is significant, as Dr. Rizvi himself claims, because it established transplantation as a successful mode of therapy in Pakistan. ${ }^{117}$ The Institute carried out the first deceased donor transplantation in 1994 in Pakistan from a kidney gifted by the Euro Transplant Foundation as well as the first local deceased donor transplantation in 1998. The Institute, under the directorship of Dr. Rizvi, was a key ideational force in propagating its policy of living related donor transplants or of a deceased donor. Dr. Rizvi in this regards writes: ${ }^{118}$

"One of the important roles of the institute has been its efforts to prohibit unrelated commercial transplants and "transplant tourism." The institute held several conferences in the country in collaboration with the World Health Organisation and the Transplantation Society to highlight the problem of transplant tourism and the sale of kidneys. It helped frame the transplant law and struggled in the parliament and courts till finally in 2007 the Transplantation of Tissue and Organ Ordinance was promulgated and the bill became law in 2010, where it was passed unanimously by the two houses of Parliament."

\footnotetext{
${ }^{115}$ Sultan, S., "Evolution of Pediatric Urology at Sindh Institute of Urology and Transplantation (SIUT)," Frontier in Pediatrics, Vol. 2 (2014): Article 88

${ }^{116}$ Rizv, Adibul H., Naqvi, Syed Ali A., Zafar, Mirza N., and Akhtar, Syed F., “A Kidney Transplantation Model in a Low-Resource Country: An Experience from Pakistan," Kidney International Supplements, Vol. 3 (2013): 236

${ }^{117}$ Ibid, 239

${ }^{118}$ Ibid
} 
The ideational thrust, however, started building up only a couple of years before when the Government, on the instructions of the Supreme Court, promulgated Transplantation of Human Organs and Tissues Ordinance in September 2007. By 2005, human organ transplantation in Pakistan had peaked to around 2,000 a year and become blatantly commercialised in cities of Lahore, Rawalpindi and Islamabad which had turned into hubs for 'transplant tourism.' This had multiple effects. On the one hand, it sparked heated debate not just in Pakistan but outside Pakistan as well from where recipients came for organ transplantation. Noorani writes "Patients from overseas, including the United Kingdom, are operated on quickly and whisked back to their own country without proper advice or postoperative treatment, so they often succumb to serious complications." ${ }^{\text {119 }}$ Akhtar narrates one such incidence when "A British newspaper published a story about 20 patients in Scotland who had jumped the National Health Service (NHS) kidney transplantation waiting list and visited Pakistan to bargain for a kidney. They forced the NHS doctors to prescribe expensive medications after their bodies had rejected the graft. ${ }^{, 120}$ On the other hand, to meet the constantly increasing demand, kidneys were bought from desperate, poor people without providing them with adequate compensation and postoperative treatment. ${ }^{121}$ Efrat claims that transformation of Pakistan's transplantation policy was influenced by three main actors, namely "advocacy by local physicians and national media coverage reinforced by efforts of international medical bodies," including the World Health Organization. ${ }^{122}$ Efrat also agrees that from the medical community it was the SIUT under leadership of its Director Professor Dr. Adibul Hassan Rizvi, which intensified its efforts in 2005 for transplant legislation,

\footnotetext{
${ }^{119}$ Noorani, M. A., "Commercial Transplantation in Pakistan," British Medical Journal, Vol. 336 (2008): 1378

${ }^{120}$ Akhtar, F., "Chronic Kidney Disease, Transplantation Practices and Transplantation Law in Pakistan, Opportunity for a Global Meditation,” Artif Organs, Vol. 33, No. 7 (2009): 572

${ }^{121}$ Noorani, M.A., 2008: 1378

${ }^{122}$ Efrat, A., "The Politics of Combating the Organ Trade: Lessons from the Israeli and Pakistani Experience," American Journal of Transplantation, Vol. 13 (2013): 1650
} 
though they were advocating for the same since early 1990s. ${ }^{123}$ On the ideational role of the SIUT and its Director Professor Dr. Rizvi, Efrat writes: ${ }^{124}$

"The SIUT physicians realised...that generating political pressure would require a broader base of support. To raise public awareness, SIUT held several seminars, symposia and press conferences that highlighted the exploitation of paid donors and called on the government to enact a transplantation law. Op-eds and letters to the press were another advocacy tool. SIUT also sought to establish a societal coalition to demand action against organ trafficking. In addition to four national medical associations, SIUT brought on board other civil-society actors of high moral stature, such as educators and members of the clergy, as well as individuals who had benefited from dialysis and transplantation. In public and media appearances, members of the coalition argued that commercial transplantations violated fundamental moral norms and called for the pursuit of ethical alternatives - first and foremost, deceased organ donation."

It was at around that time when SIUT had built enough momentum; the media in Pakistan also became critical of organ trade and started relaying human accounts of how organs are obtained from poor and vulnerable individuals. On this Efrat writes "The media coverage took specific aim at the role of the government, whose failed poverty-alleviation programs left individuals no choice but to sell their kidneys and whose failure to enact a transplant law

\footnotetext{
${ }^{123}$ Ibid, 1651

${ }^{124}$ Efrat, A., "Combating the Kidney Commerce," Civil Society against Organ Trafficking in Pakistan and Israel," British Journal of Criminology, Vol. 53 (2013): 772
} 
and later to enforce it allowed the organ trade to thrive." ${ }^{\prime 25}$ As the pressure from the medical community intensified and reinforced by media, first in 2006 the Supreme Court asked the federal and provincial authorities to curb the organ trade and then in 2007 it ordered the transplantation ordinance be established. ${ }^{126}$ Another trigger for judiciary's activism was filing of several court cases against doctors performing organ trade and on exploitation of the vendors. ${ }^{127}$

It was in this context when finally in September 2007, the then President Pervez Musharraf promulgated Transplantation of Human Organs and Tissues Ordinance. The ordinance prohibited both unrelated living organ donation and transplanting organs from Pakistani donors to foreigners, as well as prohibition on commercial dealings in human organs. ${ }^{128}$ Before the bill on the Transplantation of Human Organs and Tissues was passed into a parliamentary Act, there were two significant attempts made by counter lobby to bring amendments to the ordinance to further weaken the law that already had some loopholes. The first attack came in 2008, explains Efrat, when "organ-trade lobby sought to amend and, in fact, undermine the ordinance by relaxing the prohibitions on unrelated donation and payment donors; the lobby further suggested that allowing foreigners to receive transplants would help the country's economy." 129 An amendment proposal in this regard was submitted in January 2009 in the National Assembly but later withdrawn under intense criticism from the civil society and the media. ${ }^{130}$ A parallel attack came with a petition made to the Federal Shariat Court, a constitutional body tasked with ensuring country laws are in accordance with Islam, by owner of a private hospital in Rawalpindi that several provision of the ordinance

${ }^{125}$ Ibid, 1652

${ }^{126}$ Ibid, 1651

${ }^{127}$ Rizvi, Adibul H. et al., 2010: 195; Rizvi, Adibul H., 2009: 18

${ }^{128}$ Efrat, A., 2013: 772

${ }^{129}$ Ibid, 772

${ }^{130}$ Moazam, F., and Jafarey, A., "Pakistan's Experience with Kidney Transplantation and Trade: A Call for International Solidarity," Indian Journal of Medical Ethics, Vol. 6, No. 3 (2014): 158 
are contradictory to Sharia. Efrat recounts "the petitioner... argued that allowing the donation of a kidney only to a blood relative or a spouse violated the Qur'an call on Muslim to save a life whenever they can." ${ }^{131}$ In April 2009, the Federal Shariat Court rejected the petition and based its judgment on arguments made by defence - the Ministry of Law and Justice and the Ministry of Health - supported by three medical association and physicians from SIUT who made the case of exploitation of poor and violation of international norms. The "last significant controversy," the ending points in the policy process, came on March 17, 2010 when President Asif Ali Zardari signed the bill into parliamentary law after it was unanimously passed on November 12, 2009 in National Assembly of Pakistan and on February 10, 2010 in the Senate of Pakistan. The "first significant controversy" in organ transplantation law can be traced back to 1992 when the bill to regulate transplantation was first presented in the Senate. Late Iqbal Haider, who was the senior advocate of the Supreme Court of Pakistan and also the founding member of Human Rights Commission of Pakistan, had first drafted and introduced a bill, in his capacity of an elected Senator and member of the Functional Committee on Human Rights, to regulate human organ transplantation. He himself reflects on his efforts to regulate human organ transplantation in Pakistan "Much to my disappointment, despite my best endeavour initially as Senator and later even as Federal Minister for Law and Parliamentary Affairs, I could not succeed in the passage of this bill, in part due to objections raised by bureaucrats who were perhaps under the influence of the strong lobby supporting the illegal and immoral organ trade and transplant tourism in Pakistan." ${ }^{\prime 132}$ However, it is also important to note, as Dr. Adibul Hassan Rizvi himself writes in a book chapter published in 1991, that unethical unrelated transplantation was not emerged

\footnotetext{
${ }^{131}$ Ibid, 773

132 Jafar, Tazeen H., "Organ Trafficking: Global Solutions for a Global Problem," American Journal of Kidney Disease, Vol. 54, No. 6 (2009): 1152
} 
as a problem in Pakistan at the time. ${ }^{133}$ Coupled with a procedure that was taking place only at a handful of places and about 50 in a year, the legislators of the time did not put it high on the policy agenda and the bill never made it to the list of the business. In the same chapter, Dr. Rizvi did forewarn, "it is only a question of time that the practice may well start here [Pakistan] as well. What is stopping the sale of organs is the fact that transplantation is available predominantly in the public sector where commerce plays little role." ${ }^{, 134} \mathrm{~A}$ significant event in this respect was passing of the Human Organ Transplantation Act of 1994 in India which at the time had the bulk of 'transplantation tourism,' and where subsequently the number of foreign recipients decreased and deflected to countries that did not have any law to counter trade of human organs, i.e. Pakistan. ${ }^{135}$ A timeline of significant events shaped through ideational forces is adapted from an article published in 2010 by authors who were amongst the key actors involved in the legislative process on human organ transplantation in Pakistan.

Table 8.2:

Timeline to organ transplantation law in Pakistan ${ }^{136}$

\begin{tabular}{|l|l|}
\hline 1979 & $\begin{array}{l}\text { Renal transplantation started in Pakistan in public sector hospitals using living related family } \\
\text { donors }\end{array}$ \\
\hline 1990 s & $\begin{array}{l}\text { Renal transplantations exceeded } 500 \text { transplantations per year with first violations observed, } \\
\text { whereby some hospitals shifted from dealing exclusively with living, related donor to } \\
\text { unrelated, paid donors until these unethical practices accounted for more than } 80 \% \text { of all } \\
\text { transplantations. Later in the decade transplantations exceeded } 1000 \text { per year. }\end{array}$ \\
\hline
\end{tabular}

${ }^{133}$ Rizvi, Adibul H. and Naqvi, S.A.A., "Fallout of Commercialism in Organ Donation as Seen in Pakistan," in Walter Land and John B. Dossetor (eds.) Organ Replacement Therapy: Ethics, Justice, Commerce (Berlin: Springer, 1991): 205

${ }^{134}$ Ibid, 205

${ }^{135}$ Shimazono, Y., "The State of the International Organ Trade: A Provisional Picture Based on Integration of Available Information," Bulletin of World Health Organization, Vol. 85, No. 12 (2007): $901-980$

${ }^{136}$ Adopted from: Bile, K.M., Qureshi, J.A.R.H., Rizvi, S.A.H., Naqvi, S.A.A., Usmani, A.Q., and Lashari, L.A., "Human Organ and Tissue Transplantation in Pakistan: When a Regulation Makes a Difference," Eastern Mediterranean Health Journal, Vol. 16 (2010): S161 


\begin{tabular}{|c|c|}
\hline & $\begin{array}{l}\text { The Senate introduced a transplantation bill in 1992, based on ethical norms and conforming } \\
\text { to World Health Organization (WHO) and International Transplantation Society guidelines, } \\
\text { but the then strong counter lobby defeated the attempt. }\end{array}$ \\
\hline $2000 \mathrm{~s}$ & $\begin{array}{l}\text { Opposition to promulgating the law was sustained and commercial kidney transplantation } \\
\text { flourished with over } 1500 \text { expatriates receiving locally procured kidneys. The Ministry of } \\
\text { Health, supported by SIUT, media and civil society organisations, sustained its efforts to } \\
\text { promote legislation and bring an end to these unethical practices. WHO Provided the } \\
\text { necessary technical support through its country, regional and headquarter institutions. }\end{array}$ \\
\hline 2004 & $\begin{array}{l}\text { A member tabled a bill in the Pakistan Senate raising the momentum for action. } \\
\text { Subsequently, the subject was tabled as an agenda item in the Federal Cabinet. }\end{array}$ \\
\hline 2006 & $\begin{array}{l}\text { The organ transplantation agenda submitted to the Cabinet in } 2004 \text { was deferred in October } \\
\text { 2006. This action ignited an active campaign, where informed and investigative media reports } \\
\text { and SIUT's bold and challenging technical deliberations exposed the growing unethical } \\
\text { lucrative kidney trade. }\end{array}$ \\
\hline 2007 & $\begin{array}{l}\text { Exploitative organ transplantation led to a judicial action in July 2007, whereby the Supreme } \\
\text { Court of Pakistan took a suo motu notice advising the Government to promulgate the } \\
\text { transplantation law. }\end{array}$ \\
\hline 2007 & $\begin{array}{l}\text { The transplantation ordinance was promulgated in September } 2007 \text { by the President of } \\
\text { Pakistan }\end{array}$ \\
\hline 2008 & $\begin{array}{l}\text { Attempts were made by the counter lobby through the Standing Committee for Health at the } \\
\text { National Assembly to water down the law by introducing loopholes implicitly condoning } \\
\text { organ sale and allowing expatriates to acquire kidneys for lucrative fees. The Standing } \\
\text { Committees rejected these endeavours for Health and Human Rights. }\end{array}$ \\
\hline 2008 & $\begin{array}{l}\text { A case was filed before the Federal Shariat Court of Pakistan, challenging the law, whereby } \\
12 \text { hearing sessions were held in Islamabad, Lahore, and Karachi, unanimously defeating all } \\
\text { submitted objections and rendering all stipulated clauses of the law sustained, including the } \\
\text { illegality of all forms of organ sale. }\end{array}$ \\
\hline 2009 & $\begin{array}{l}\text { On } 23 \text { June 2009, the Supreme Court took suo motu notice against private hospitals accused } \\
\text { of violating the law and performing illegal transplantations, who when summoned by the } \\
\text { court made commitments to comply with the law. }\end{array}$ \\
\hline 2009 & $\begin{array}{l}\text { On } 12 \text { November } 2009 \text {, the National Assembly of Pakistan unanimously passed the bill on } \\
\text { the recommendation of its Standing Committee for Health. }\end{array}$ \\
\hline 2010 & \\
\hline
\end{tabular}


Table 8.2:

Timeline to organ transplantation law in Pakistan ${ }^{136}$

2010 On 17 March 2010, the President of Pakistan signed the bill making it a law.

In the case of organ transplantation law in Pakistan, and as Efrat argues the main ideational force was of local physicians with the SIUT at the forefront under the leadership of Professor Dr. Adibul Hassan Rizvi. ${ }^{137}$ They were supported by international medical bodies, namely the Transplantation Society and the World Health Organization and rallied under the banner of the Transplantation Society of Pakistan. The major thrust to this ideational force came at around 2005 when media, print and broadcast, started highlighting stories of people being exploited to sell their kidneys due to extreme poverty and who still could not manage to change their lives but, on the contrary, their situation worsened due to depleted health and growing debt. ${ }^{138}$ This triggered judicial activism in 2007 and the incumbent government was forced to promulgate an ordinance to regulate organ transplantation in Pakistan. Even after the promulgation of the ordinance, the interest of the media did not deplete and more cases were brought forward where organ-trade rackets were shown being apprehended. On media reports, the then Chief Justice of Pakistan Iftikhar Muhammad Chaudhry in 2009 once again took the judicial initiative and summoned private hospitals reportedly involved in organ trading. ${ }^{139}$ With consistent pressure from the medical community, supported by international medical institutions, and reinforced by media and judicial activism, the bill on human organ transplantation was signed into law in 2010.

\footnotetext{
${ }^{137}$ Efrat, A., 2013: 1650

${ }^{138}$ Freedom House. Freedom in the World 2008: The Annual Survey of Political Rights in Civil Liberties (Maryland: Rowman \& Littlefield Publishers, 2008): 541

${ }^{139}$ Dawn Daily, "SC Directs Kidney Centre to File Report on Organ Transplantation," June 24, 2009; and Dawn Daily, "SC Issues Notices to Balochistan, Sindh in Kidney Patients Case, November 13, 2009
} 


\subsection{2: UNDERLYING IDEATIONAL DIMENSIONS TO THE ORGAN TRANSPLANTATION LAW IN PAKISTAN}

A total of nine in-depth interviews were conducted to study the ideational dimensions that became the basis for the passing of the organ transplantation law in Pakistan. Dr. Farhat Moazam, who had strongly advocated for organ transplantation bill under the leadership of Dr. Adibul Hassan Rizvi, represented SIUT. Dr. Saeed Akhtar, who is the Director of the Urology and Transplantation Department in one of the largest private-sector hospitals in Pakistan and was also the President of the Transplantation Society of Pakistan, represented the medical fraternity who had actively pursued the legislation. Two former federal secretaries were also interviewed in whose term at the Ministry of Health the deliberations on various contours of the bills were conducted. Two parliamentarians, namely Dr. Shahzad Waseem who had tabled the bill in 2003 as private member and Dr. Nadeem Ehsan who was Chairman of the parliamentary Standing Committee on Health at the time of the passing of the legislation, were interviewed. In addition, Dr. Ghulam Nabi Kazi who had provided technical backstopping from the World Health Organizations' platform and Professor Major Gen (Rtd.) Dr. Abdul Qadir Usmani who was appointed as the first head of the Human Organ Transplantation Authority (HOTA) to oversee the implementation of the legislation, were interviewed (see table 8.6 at the end of the chapter for further details).

The interviewees agreed to the central role of Professor Dr Adibul Hassan Rizvi in bringing to the fore the issue of commercialisation of organ transplantation in Pakistan, who together with his team is also credited with successfully carrying out the first cadaver renal transplant in the country. 
"SIUT under the leadership of Dr. Adeeb played the leading role. While it was a collective work but the leading role remained with the SIUT." [Farhat Moazam, Professor and Chairperson, Centre of Biomedical Ethics and Culture, SIUT]

"Professor Adeeb Rizvi first introduced me to this issue in 2002 and 2003 and then of course the Headquarter and the Regional Office come into action as well." [Dr. Ghulam Nabi Kazi, National Professional Officer, World Health Organization]

“The main role was undoubtedly of Dr. Adeeb." [Dr. Saeed Akhtar, Former President, Transplantation Society of Pakistan]

"The most important voices raised during my time as the Secretary were from the civil society and I think the deliberations of Professor Adeeb had a great deal of role as he was the opinion creator and also because of his age and experience. Whenever he used to raise any issue, people used to give credence to that." [Dr. Ijaz Rahim, Former Federal Secretary of Health]

"The prime role was played before I had joined [HOTA] and even after my joining was of the Executive Director of SIUT Professor Adeeb. " [Prof Major Gen (Rtd.) Dr. Abdul Qadir Usmani, Former Chairman, HOTA]

"This bill came to me in 2009 when I met Dr. Adeeb Rizvi of SIUT ... then I first came to know about this issue" [Dr. Nadeem Ehsan, Former Member 
National Assembly and Chairman of the Parliamentary Standing Committee on Health].

From the interviews, it can be safely argued that the SIUT was the main driving force under the leadership of Professor Dr. Adibul Hassan Rizvi who were successful in creating a discourse on the issue of organ transplantation. They engaged both the scientific community through research publication, participation in conference and seminars and lectures as well as the public at large through engaging with the news media. Dr. Farhat Moazam provides a detail account on how they were able to mobilise different sections of the society:

When SIUT started organ transplantation in 1985, it had then and still has a very clear policy that kidneys will be obtained from only living related donors and the reason for that is of course ethical. Our role was through our Center; the role we played was both research and also writing to engage with the local press, for instance letter to the editors, articles and op-eds. Our role was also going to the media and presenting our case and providing arguments from both the perspective of ethics and religion. With SIUT, the Transplantation Society of Pakistan, Nephrology Association and other hospitals, i.e. Shifa Hospital, raised this issue by approaching press and civil society and by writing articles and op-eds to start the movement. [Farhat Moazam, Professor and Chairperson, Centre of Biomedical Ethics and Culture, SIUT] 
Dr. Saeed Akhtar, who was the President of the Transplantation Society of Pakistan during this time and also one of the key members in instigating this movement provide further details:

"We did multiple programmes on television, did talk shows on radio, publicised this in newspapers and launched a massive campaign against this practice. We were provided support by the media. We met a lot of people and convinced them that it is ethically, professionally and medically wrong. We even met the Chief Justice and President of Pakistan in person and asked them to push for this legislation and of course they helped. Even then the Health Minister kept on delaying it." [Dr. Saeed Akhtar, Former President, Transplantation Society of Pakistan]

Dr. Ijaz Rahim, who was the Federal Secretary of Health during the incubation years, agrees:

\author{
"This powerful influence was generated by SIUT. I remember that President \\ Musharraf used to chase people that Dr. Adeeb has sent this and why isn't \\ this moving forward and getting through. [Dr. Ijaz Rahim, Former Federal \\ Secretary for Health]
}

When asked the reasons why such a bill was needed, respondents generally hinted to the shame of being internationally labelled as a 'kidney bazar' and guilt of associated to such a practice. 
"There was nothing in the law that says that this [selling and buying human organs] is wrong or you can't do this. And this became big business to an extent that private sector openly and directly started advertising transplant packages in US\$ to attract foreigners... and essentially we were known as “kidney bazar." [Farhat Moazam, Professor and Chairperson, Centre of Biomedical Ethics and Culture, SIUT]

"The situation at the time was that Pakistan was declared a country with transplantation tourism and things were really bad. Buying and selling organs had become a routine affair." [Dr. Ghulam Nabi Kazi, National Professional Officer, World Health Organization]"

"I returned to Pakistan in 2000 with the intention to contribute something back to my country, but to the biggest surprise of my life, I found the organ trade to be on its peek and that was extremely hurtful and painful for me. It was almost like a prostitute den was being run and internationally we were ridiculed and thought of as those who can even selloff their mothers." [Dr. Saeed Akhtar, Former President, Transplantation Society of Pakistan]

"The world had regulated itself and we had become a kidney bazar and it formed itself functioning on market principles of supply and demand. This made into a human rights issue as to meet the supply people were started being exploited and manipulated into selling their organs." [Dr. Shahzad Waseem, Member National Assembly] 
In addition, respondents generally raised normative implications of organ trade as being exploitative and unethical.

"Apparently they were saving lives or trying to save lives, even if you do the right thing with bad motives the ethical practices are questioned. There were lot of malpractices and extortion." [Dr. Ghulam Nabi Kazi, National Professional Officer, World Health Organization]

"When ever any profession is turned into a trade, any profession, then the ethics and professional values attached to it are put behind. The first priority then becomes business." [Dr. Shahzad Waseem]

"This was very much a public issues, because this had become an industry in Pakistan and minting money like anything. This was an illegal business of around two and half billion rupees per year." [Dr. Nadeem Ehsan].

However, from the discussion it becomes apparent that the orientation to the need for such a law on instrumental grounds was primarily derived from exposure to international practices, which is more reflected in scientific publications than in public discourse.

"In United States they passed the National Organ Transplant Act, and provided for the established of an Organ Procurement and Transplantation Network. Through this, a United Network for Organ Sharing was created which made rules for organ transplantation that are implemented all across the world with only a few changes. We only added Islamic perspective in it 
after discussing this with scholars." [Dr. Saeed Akhtar, Former President, Transplantation Society of Pakistan]

As for the passing of the legislation, respondents agree that the turning point came when the national media started picking up stories of exploitation and malpractices associated with organ transplantation. This culminated into the Chief Justice Iftikhar Muhammad Chaudhry taking a suo motu notice of the issue and compelling the government to take appropriate regulatory measures to bring an end to organ trade in Pakistan.

"This particular legislation succeeded because of the public opinion generated due to the scale of the malpractice, it was highly published in our newspapers and that played a very significant role." [Dr. Ijaz Rahim, Former Federal Secretary for Health]

\begin{abstract}
"Because this was sensational news, the press started picking this up that those who selling kidneys are exploited ... it was indeed at this time with SIUT capitalising and transforming this into a movement." [Dr. Farhat Moazam, Professor and Chairperson, Centre of Biomedical Ethics and Culture, SIUT]
\end{abstract}

He was an activist Chief Justice, and the press helped a great deal...we were invited to channels to talk about this issue. And when the Chief Justice took the suo motu notice and gave a ruling that the government needs to do something about this a year later the President General Pervez Musharraf passed an ordinance. It was definitely due to the direct result of pressure by media, associations and also by some of the leading names in civil society; 
SIUT was always on the lead." [Farhat Moazam, Professor and Chairperson, Centre of Biomedical Ethics and Culture, SIUT]

“Certain circumstances did help, such as having a very powerful Chief Justice at the time." [Dr. Ghulam Nabi Kazi, National Professional Officer, World Health Organization]

"For us the surprising factor was the suo motu notice, God willing, Iftikhar Chaudhry [Chief Justice of Pakistan] who made this happen. [Dr. Saeed Akhtar, Former President, Transplantation Society of Pakistan]

"Probably the courts and the higher judiciary were not that proactive at that time. With the then Chief Justice, who was real champion of judicial activism, put his foot down and said this law has to be put in place so that is when the things started rolling." [Professor Major Gen (Rtd.) Dr. Abdul Qadir Usmani, Former Chairman, HOTA]

Interestingly, even the government officials of the time agreed that the main driving force behind this bill was of civil society and the political representatives had little or no role in passing of this bill.

When the Peoples Party government came they were unconcerned about this issue. I will call it a civil society driven law, by professionals and media. [Dr. Saeed Akhtar, Former President, Transplantation Society of Pakistan] 
"Let me tell you that the role of the legislators in all such bills is the weakest and delay is also there because commitment of legislators to public health agenda is usually marginal." [Dr. Ijaz Rahim Former Federal Secretary Health]

This bill in one way or the other was lying in the National Assembly for 16 years. [Dr. Nadeem Ehsan, Former Member Parliament and Chairman of the Parliamentary Standing Committee on Health]

SIUT was taking the lead, while government had not done anything, under the leadership of Professor Adeeb and WHO provided full support to him from HQ to regional to national offices. [Dr. Ghulam Nabi Kazi, National Professional Officer, World Health Organization]

This issue had become massive, due to media and judiciary, and the PPP just could not reverse the momentum. [Dr. Shahzad Waseem, Member National Assembly]

Respondents acknowledged the long time the bill took to become a legislative law and blamed disinterestedness of politicians, lack of prioritisation given to non-communicable diseases in the public health fraternity and the resistance put up by the anti-bill lobby.

“The gestation period was very long. Since 2000, as part of MGDs, Pakistan was focusing primarily on mother and child health and communicable diseases while non-communicable diseases were completely sidelined. It was 
a non-priority area for the Government of Pakistan and donor partners as well." [Dr. Ghulam Nabi Kazi, National Professional Officer, World Health Organization]

"While SIUT had been agitating for a long time that we need to have a law but nothing was happening but when it expanded so much then the press started picking up the cases." [Dr. Farhat Moazam, Professor and Chairperson, Centre of Biomedical Ethics and Culture, SIUT]

"It took so much time because of the resistance of the people who were benefiting from the organ trade." [Dr. Saeed Akhtar, Former President, Transplantation Society of Pakistan]

"As we pushed this bill further, we started realising that we are up against a very strong Mafia. Then we decided that whatever government comes and goes we would continue pressurising for this bill." [Dr. Shahzad Waseem, Member National Assembly]

"During those 16 years this bill remained pending because of all the politics, let's say 'dirty politics.' You have to put aside all the politics and you have focus on priorities purely on humanitarian grounds. We took it as a humanitarian issue." [Dr. Nadeem Ehsan, Former Member Parliament and Chairman of the Parliamentary Standing Committee on Health] 
Involvement of general public in drafting the legislation was at best little and it primarily remained an expert driven piece of legislation. While the media and public sentiments did create the pressure, which eventually led to the Supreme Court taking a suo motu notice, the technical nature of the bill restricted its drafting to the subject-experts only. Also, study of similar laws from developed countries and those in the region helped in drafting the legislation.

Yes I think it was an expert driven law, all along the technocrats were involved. [Dr. Ghulam Nabi Kazi, National Professional Officer, World Health Organization]

"SIUT was very closely involved in the write up of the law... India was facing a similar issue and yes we studied the law passed by India because they are so similar in culture and disadvantages. [Dr. Farhat Moazam, Professor and Chairperson, Centre of Biomedical Ethics and Culture, SIUT]

"What they did [SIUT], they studied the laws of different countries, especially our Eastern neighbours." [Professor Major Gen(R) Dr. Abdul Qadir Usmani, Former Chairman, HOTA]

"Dr. Adeeb and I had already prepared a draft, we further worked on the same and made provisions for cadaveric donation because in West we knew that there is a system in place for such transplantation. We also studied the Indian legislation. In 1994, India had passed a law after a damning documentary run on international media. There is a law in Saudi Arabia, and 
in Qatar also. We gathered relevant information from all this and then from the perspective of Pakistan made one." [Dr. Saeed Akhtar, Former President, Transplantation Society of Pakistan]

The homework was already being done and the ground laid and people were prepared to accept it, so everything was present in form of an ordinance which we got it redrafted in the act of the parliament and just the signatures were required. [Professor Major Gen (Rtd.) Dr. Abdul Qadir Usmani, Former Chairman, HOTA]

The legislation movement met with a stiff resistance from anti-bill lobby mainly comprising individuals involved in commercial trade of organs. Their resistance went well beyond the passing of the ordinance challenging the law in the Federal Shariat Court on grounds that it is against the injunctions of Islam and Shariat. The Shariat Court set aside the petition in a 90page judgement stating the honourable court has not found anything repugnant to or in contravention of Islamic injunction or the Sharia and Sunnah. An appeal was made against the verdict, which was also turned down. Finally, the anti-bill lobby went to the Supreme Court's Sharia Appellate Bench. Sensing their defeat, they withdrew their application before the decision was made.

"We were fighting against a very strong lobby of the private sector doctors and to them there was nothing wrong in it and lot of them were politically very well connected...the tipping point, however, really came when the Supreme Court took the suo motu notice." [Dr. Farhat Moazam, Professor and Chairperson, Centre of Biomedical Ethics and Culture, SIUT] 


\begin{abstract}
"People saw this bill as something that would obstruct their businesses and underhand methods so they were intimidated rather than pleased with this bill." [Dr. Ghulam Nabi Kazi, National Professional Officer, World Health Organization]
\end{abstract}

"After the bill was passed, initially there was a lot of resistance from the people who were involved in this activity, there were threats, they were hurling abuses, and all sorts of impediments that one could expect. But internationally it was received very well." [Professor Major Gen(R) Dr. Abdul Qadir Usmani, Former Chairman, HOTA]

Professor Dr. Adibul Hassan Rizvi, as the head of the Sindh Institute of Urology and Transplantation, played the central role in brining the legislation on organ transplantation in Pakistan. He was greatly helped by his colleagues as well as the larger fraternity through the platform the Transplantation Society of Pakistan. While the scientific discourse elucidated to both the instrumental needs and normative reasoning for regulating the practice of organ transplantation, their orientation was the result of exposure to international norms and practices. In part, their motivation was the result of expectations by their international peers whom they interacted during international conferences, workshops and symposiums.

On the part of the government, the need for regulating the organ transplantation in Pakistan was due to the judicial activism that necessitated legislation. In his interview Dr. Nadeem Ehsan, who is presently the member of the National Parliament and had introduced the similar bill in 2003 as a private-member bill, explains that ordinances and orders passed by 
the President General Pervez Musharraf were challenged when the democratic government returned in 2008 and referred those to the Supreme Court. The Supreme Court then referred a total of 34 ordinances, including the one on organ transplantation, to the Parliament for revalidation in 120 days. Professor Major General (Retired) Dr. Abdul Qadir Usmani, in his interview, shed light on why the ordinance was passed at the first instance and only later the legislation was made, ““"The Chief Justice had given the order to have a legislation passed on this issue but since the house was not in session and the deadline had approached an ordinance was promulgated." Regardless, the main catalyst was the notice taken by the Chief Justice. Dr. Saeed Akhtar, on this very point agues that "President Musharraf did not make much of a difference... once the Chief Justice had made the judgment, even though the Health Minister had tried to delay things, he had given a notice and a deadline too." The interest of senior judiciary, especially of the Chief Justice, was aroused because of the media coverage of cases of exploitation. Considering the Chief Justice had taken a popular course and the unprecedented number of suo motu notices on issues of public interest he had deliberated upon, it was only a matter of time he would have addressed the issue of organ transplantation once it came into the limelight. The medical practitioners primarily shaped the policy agenda and public participation appeared later with the involvement of news media and civil society forums. Similar to the legislation against the practice of workplace harassment, the agenda was originated and given shape outside the legislature. However, the contestation to the policy proposal came from both outside and inside the legislature that led to delay in passing of the legislature. The resolution to the contestation came with the intervention of the senior judiciary. 


\section{4: THE RIGHT TO FREE AND COMPULSORY EDUCATION ACT, 2012}

The Right to Free and Compulsory Education Act, 2012 received the assent of the then President Asif Ali Zardari on December 19, 2012 and became an act of the parliament. The Parliament had adopted the bill on November 13, 2012 and the Senate had passed the bill on July 9, 2012. Unlike the previous two acts, which extended to the whole of Pakistan, this act applies to only those schools established by the Federal Government and Local Government in Islamabad Capital Territory and provides for free and compulsory education to all children of the age five to sixteen years in schools. It defines "free education" as education free of any education related costs including expenditure on stationary, school bags and transport. ${ }^{140}$ The Act in Article 3 affirms fundamental right of every child to free and compulsory education. ${ }^{141}$ The same Article further provides that "No child shall be liable to pay any kind of fee, charges, expenses, etc., which may prevent him from pursuing and completing the education," and makes it the obligation of the Government to provide free education, ensure compulsory admission, attendance, completion of education and admission of children of migrant families, as well as safety of travel of the child and the teacher to and from school. It also makes the government responsible for ensuring availability of a neighbourhood school and that the disadvantaged child is not discriminated against and prevented from, on any grounds whatsoever, pursuing and completing education. The Article 3 also makes it the responsibility of the government to provide infrastructure including school building, playgrounds, laboratories, teaching learning material and teaching staff, monitor functioning of schools within its jurisdiction, decide the academic calendar, provide all training facilities for teachers and students and ensure good quality education conforming to the prescribed

\footnotetext{
${ }^{140}$ The Gazette of Pakistan, "The Right to Free and Compulsory Education Act, 2012," December 24, 2012

${ }^{141}$ Ibid, Article 3
} 
standards and norms, timely prescribing of curriculum and courses of study for education; and provide proper training facility for teachers. ${ }^{142}$ The Act also contains provisions for special education for those children who could not complete their education, right of children to transfer to other schools for completing education, and duty of parents to ensure that their child is attending school until the prescribed education is completed. ${ }^{143}$ Article 10 of the Act also makes private schools responsible for free education "to the extent of at ten per cent of the strength of that class, disadvantaged children in the neighbourhood and provide free education till the educational level of that school." "144 Article 15 of the Act stipulates that "No school shall be established or registered or continue to function, unless it fulfils the prescribed norms and standards." ${ }^{145}$ Article 16 of the Act provides for a School Management Committee "consisting of the representatives of the appropriate government, teachers, parents of children admitted in such school" and responsible for monitoring the general working of the school; ensuring that the prescribed norms and standards are observed; ensuring that the education policy of the appropriate government is implemented; preparing and recommending the annual development plan; monitoring the utilisation of the aids and grants received from the appropriate Government or any other source; and performing such other functions as may be prescribed or entrusted to it by the appropriate government. ${ }^{146}$ The Act also provides for terms and conditions of service of teachers, their duties, and touches upon other related matters. ${ }^{147}$ The Article 25 of the Act calls for government, from time to time, “inspect or cause to be inspected a registered educational institution for the purpose of

\footnotetext{
${ }^{142}$ Ibid

${ }^{143}$ Ibid, Article 4, 5 \& 8

${ }^{144}$ Ibid, Article 10

${ }^{145}$ Ibid, Article 15

${ }^{146}$ Ibid, Article 16

${ }^{147}$ Ibid, Article 17, 18 \& 19
} 
ascertaining that this Act and the rules made under this Act have been and are being complied with."148

The reception given by print and broadcast news media to passing of the legislation on Free and Compulsory Education was cautious and at best showed passive optimism. The Express Tribune comments on passing of the bill by the National Assembly that "perhaps, our government has begun paying closer attention to Pakistan's youth and its future." $" 149$ Another article on Express Tribune terms the bill as "little more than a metaphorical pat on the back for its catalysts: noted parliamentarians and donor agencies." ${ }^{150}$ Jamil Nasir, in his article on the News - makes similar assertions that "Cost-benefit analysis, which is now at the core of public policy formulation in developed countries, is seldom conducted with the result that even well-intentioned public policies finally do not produce the intended results," and he continues that "In their present shape, the penal provisions of the 'Right to Free and Compulsory Education Bill 2012' unanimously passed by the National Assembly to ensure free and compulsory education to all children within the age bracket of 5-16 years are also likely to flounder badly at the end of the day." "welcome news" but also cautioned, "legislation is not enough to ensure education in a country where poverty and social insecurity remain a glaring reality." ${ }^{152}$ On the other hand, international development organisations generally hailed the passage of the bill. United Nations Educational, Scientific and Cultural Organization, a specialised Agency of the UN system, "Lauded the Senate of Pakistan on the passage of Right to Free and Compulsory

\footnotetext{
${ }^{148}$ Ibid, Article 25

${ }^{149}$ Express Tribune, English Daily, "Free and Compulsory Education," November 14, 2012

${ }^{150}$ Express Tribune, English Daily, "Right to Education Bill 2012: Little More Than a Pat on the Back of Parliamentarians, Donors," by Myra Iqbal, November 17, 2012

${ }^{151}$ The News, "Good Intentions, Bad Incentives," by Jamil Nasir, November 24, 2012

152 The News, Education Bill," November 15, 2012
} 
Education Act yesterday, on 9th July 2012."153 Similarly the Child Rights Movement, a network of more than 100 organisations working for the rights of children, also welcomed the enactment of the Right to Free and Compulsory Education Act 2012. ${ }^{154}$ The Human Rights Commission of Pakistan in its 2012 report on Country's performance against fundamental rights and freedoms considered the legislation as a "positive development."155 United Nations Children's Fund, another UN specialised agency, writes in its 2012 annual report that it was due to its "policy dialogue for education reform, particularly via provincial parliamentary caucuses [that was] pivotal for the passage of the 'Right to Free and Compulsory Education' Bill." 156 So while the international development and nongovernment organisations were upbeat about the legislation, the media raised questions on the ability of the government in fulfilling its provisions of 'free and compulsory education' for all children aged 5 to 16 years old.

It is true that millions of children in Pakistan are out-of-school. According to UNICEF and UNESCO estimations, one-third of primary-school-age children (34.4\%) from age 5 to 9 or around 6.5 million children are out of school. Another 2.7 million children from age 10 to 12 , which equates to $30.1 \%$ of all children in this age group, are also out of school. ${ }^{157}$ This together equates to nearly 10 million children in the age group 5 to 12 who are not attending any form of schooling. According to official statistics, only half (51\%) of Pakistan's

\footnotetext{
${ }^{153}$ UNESCO Statement, "UNESCO hails Passage of Right to Free Education Bill by the Senate," July 10,2012

${ }^{154}$ The News Tribe, "Universal Children's Day: CRM Urges Government to Accept the UPR Recommendations on Child Rights," by Shahid Abbasi, November 20, 2012

${ }^{155}$ Human Rights Commission of Pakistan, State of Human Rights in 2012 (Lahore: HRCP, 2013): 179

${ }^{156}$ UNICEF Annual Report 2012 for Pakistan, ROSA, 2013: 4

${ }^{157}$ UNICEF. All Children in Schools by 2015: Global Initiative on Out of School Children - Out of School Children in the Balochistan, Khyber Pakhtunkhwa, Punjab and Sindh Provinces of Pakistan (Islamabad: UNICEF Pakistan, 2013): ix
} 
population has completed primary schooling. ${ }^{158}$ Net enrolment rate, which is children age 5 to 9 enrolled in primary schools divided by the number of children in the same age group, is only $57 \%$. Similarly, the net enrolment rates at middle level among children age 10 to 12 year is $22 \% .{ }^{159}$ In terms of educational facilities, government statistics show that only $40 \%$ schools have electricity, less than $60 \%$ have drinking water and latrine facilities, and a little more than $60 \%$ have a boundary walls. ${ }^{160}$ According to a Transparency International report, Pakistanis consider education sector fourth most corrupt sector in $2010 .{ }^{161}$ The report also highlights thousands of so-called 'ghost-schools' and 'ghost-teachers' that exist on government's roster but "provide no services to students, although the teachers or administrators assigned to these schools continue to receive a salary." ${ }^{\prime 162}$ The National Education Policy of 2009, introduced before the subject of education was delegated to provincial governments from federation under the eighteenth amendment to the Constitution, recognises that "education in Pakistan suffers from two key deficiencies: at all levels of education, access to educational opportunities remains low and the quality of education is weak." ${ }^{, 163}$ Under overarching priorities for widening access and raising quality, the policy asks provinces and area governments to "affirm the goal of achieving universal and free primary education by 2015 and up to class 10 by 2025."164 The policy, however, did not delve upon affirmative legislative measure whereby education is made 'free and compulsory.' Subsequent to the eighteenth constitutional amendment, the functions of education ministry have been devolved to provinces. On September 16, 2011, a National

\footnotetext{
${ }^{158}$ Federal Bureau of Statistics, Pakistan Social and Living Standard Measurement Survey (Islamabad: Statistic Division, 2013): Section 2.2

${ }^{159} \mathrm{Ibid}$

${ }^{160}$ National Education Management Information System, Pakistan Education Statistics 2011 - 12 (Islamabad: Ministry of Education, Trainings and Standards in Higher Education, 2013): 45 - 47

${ }^{161}$ Gilani, Syed A., "Ghost Schools in Pakistan," Gareth Sweeney, Krina Despota and Samira Lindner (eds.) Global Corruption Report: Education (Abingdon: Routledge, 2013): 40

${ }^{162}$ Ibid

${ }^{163}$ Ministry of Education, National Education Policy 2009 (Islamabad, Ministry of Education, 2009): 13

${ }^{164}$ Ibid, 19
} 
Education Conference was held in Islamabad presided by the-then Prime Minister Syed Yusuf Raza Gilani where a Joint Declaration on Education was issued that stated "National Education Policy 2009, subject to such adaptations as are necessitated in view of the 18th Constitutional Amendment, shall continue to be jointly owned national document."165 The eighteenth constitutional amendment also added Article 25A that states, "The State shall provide free and compulsory education to all children of the age of five to sixteen years in such manner as may be determined by law," that eventually paved path for a federal legislation on 'free and compulsory education' in $2012 .{ }^{166}$ Eighteenth amendment and ensuing Article 25A to Constitution of Pakistan is discussed in more detail in the next section.

It is important to note that even before Article 25A, the right to free and compulsory education was an obligation on the State of Pakistan as being signatory to various international covenants, declarations and frameworks of action. On the occasion of signing the bill into a parliamentary law, the then-President Asif Ali Zardari also referred to such normative contents and said that it is a "historic day for the people of the country as the government has fulfilled the promise of protecting all fundamental rights after declaring education as the basic right of the citizens." ${ }^{, 167} \mathrm{He}$ further said, "Law would ensure that no child remains out of school hence realising country's international commitments..." and "we will honour our international commitments and will achieve the targets set in Education for All and Millennium Development Goals." "168 Other government parliamentarians had expressed similar sentiments when the National Assembly had passed the bill. Shahnaz Wazir

${ }^{165}$ Mujahid-Mukhtar, E., Situation Analysis of the Education Sector (Islamabad: UNESCO, 2011): 25

${ }^{166}$ Article 25A, the 1973 Constitution of Pakistan

167 The News, "President Signs the Right to Free and Compulsory Education," by Tahir Hassan Khan, December 20, 2012

${ }^{168}$ Ibid 
Ali, who was Advisor to the Prime Minister, had said "the entire National Assembly should take pride in it because the law would ensure a bright future for children."169

Yasmeen Rehman, a government parliamentarian who had tabled the bill in the National Assembly as a private-member bill, while speaking to the House on the day when the bill was passed said that "provision of a compulsory education was a fundamental right of every children and the bill would ensure better education to the children." ${ }^{170}$ In its statement of objects and reasons, the bill refers to the Article 25A of the 1973 Constitution of the Islamic Republic of Pakistan which provides for free education to all children of aged five to sixteen as a fundamental right and its provision is a responsibility of the state. In the next section, the ideational forces at play at the global level and within Pakistan are studied in more detail.

\subsubsection{IDEATIONAL FORCES BEHIND THE RIGHT TO FREE AND COMPULSORY EDUCATION ACT IN PAKISTAN}

The right to free and compulsory education first culminated on a world scale out of the democratic movement of the early twentieth century and general cause of "right of the people. ${ }^{171}$ " John Dewey, in particular, is credited for providing theoretical basis for "education for all," and seeing all people as engaged in the educative process and children also individuals with rights and claims of their own. ${ }^{172}$ In the context of Pakistan, however, its roots are connected to country's colonial past. In Britain, the Compulsory Education Act was first passed in 1870 and by 1881 it had established all over the country with enrolment

\footnotetext{
${ }^{169}$ Dawn, "NA Adopts Bill on Free School Education," by Khawar Ghumman, November 13, 2012

${ }^{170}$ The News, "Father to be Punished for Not Sending Child to School," November 14, 2012

${ }^{171}$ Warde, William F., "John Dewey's Theories of Education," International Socialist Review Vol. 21, No. 1 (1960): $5-8$

${ }^{172}$ Dumbleton, P., "A Philosophy of Education for All?" British Journal of Special Education, Vol. 17, No. 1 (1990): 17
} 
increased from less than half to nearly $100 \% .{ }^{173}$ In 1882 , the British Raj established the first commission on education called Hunter Commission with an objective to assess the state of elementary education in the Indian empire. The Commission in its recommendations placed special emphasis on regarding primary education as the instruction of masses and need for extending it to backward districts. ${ }^{174}$ In 1883 , the princely ruler of Baroda introduced compulsory education for boys in one of the districts and in 1906 extended to the rest of the state. Gopal Krishna Gokhale, President at the time of the Indian National Congress, presented a private bill on compulsory education to Imperial Legislative Council but was rejected. The first law on compulsory education in British India was eventually passed in 1917, popularly know as Patel Act, and by 1921 every province had such a legislation enacted. ${ }^{175}$ So when the first National Education Conference was held in Karachi soon after independence in 1947 to recognise the colonial education system it uphold the principle of compulsory education and made the recommendation to make primary education free and compulsory till Class-VIII. ${ }^{176}$ The notion of free and compulsory education was retained in the constitutions of both India and Pakistan and reflected in subsequent policies as a desirable goal.

Internationally, it was the Universal Declaration on Human Rights, which for the first time laid out the principle of free and compulsory education and demanded a policy response at the global level. Pakistan was among the 48 countries that signed on to the Universal Declaration of Human Rights in United Nations General Assembly's session held on

\footnotetext{
${ }^{173}$ Besant, A., "The Case for India," the Presidential Address Delivered by Annie Besant at the Thirty-Second Indian National Congress Held at Calcutta December 26, 1917

${ }^{174}$ Aggarwal, D. D., History and Development of Education in India: Principles and Practice of Elementary Education in India, Vol. 3 (New Delhi: Sarup and Sons, 2002): 56

${ }^{175}$ Panagariya, A., Chakraborty, P., and Rao M. G., State Level Reforms, Growth, and Development in Indian States (Oxford: Oxford University Press, 2014): 261

${ }^{176}$ Durrani, N., "Pakistan: Curriculum and the Construction of National Citizen," in Mah-e-Rukh Ahmed (ed.) Education in West Central Asia, 221 - 240 (London: Bloomsbury Academic, 2013): 224
} 
December 10, 1948. The Article 26 of the Declaration states, "Everyone has the right to education. Education shall be free, at least in the elementary and fundamental stages. Elementary education shall be compulsory."177 The declaration essentially became the bedrock for all subsequent policy and legislative measures for the provision of and in efforts to ensuring 'free and compulsory education' across the world. Chapman writes, "The right to education is one of the most affirmed economic, social and cultural rights." ${ }^{\prime 178}$ In addition to the Universal Declaration of Human Rights, there are a number of other international instruments, listed in the following table, that recognise the right to education. It is important to note that Pakistan did not assent to most of the human rights treaties emanating from the Universal Declaration of Human Rights till the turn of the twenty-first century. It was, however, among the pioneering countries that signed into and ratified the Convention on the Rights of the Child in 1990 that demanded State Parties to make primary education compulsory and available free to all in its very first Article (see table 8.3).

In addition to its colonial heritage, these various international instruments on free and compulsory education became ideational forces of their own and started impacting how country-level policies and legislation on education were formed. Periodic reporting from states plays an instrumental role in advancing particular legislative and policy agendas. Periodic reporting is one of the mechanisms though which United Nations exercises its supervision of international human rights treaties, such as those mentioned above, is through consideration of periodic reports by State Parties. ${ }^{179}$

\footnotetext{
${ }^{177}$ Article 26 of The Universal Declaration of Human Rights, retrieved from http://www.un.org/en/documents/udhr/index.shtml on June, 17, 2014

${ }^{178}$ Chapman, Audrey R., "Development of Indicators for Economic, Social and Cultural Rights: The Rights to Education, Participation in Cultural Life and Access to the Benefits of Science," in Yvonne Donders and Vladimir Volodin (eds.) Human Rights in Education, Science and Culture: Legal Development and Challenges, 111 - 152 (Burlington: Ashgate Publishing, 2007):

${ }^{179}$ Olowu, D., International Law: A Textbook for the South Pacific (Washington DC: CDPublishing, 2010): 180
} 


\begin{tabular}{|c|c|c|}
\hline Instrument & Reference & Status \\
\hline $\begin{array}{l}\text { Universal Declaration of } \\
\text { Human Rights, } 1948\end{array}$ & $\begin{array}{l}\text { Article 26: Everyone has the right to education. Education } \\
\text { shall be free, at least in the elementary and fundamental } \\
\text { stages. Elementary education shall be compulsory }\end{array}$ & $\begin{array}{l}\text { Voted in } \\
\text { favour in } \\
1948\end{array}$ \\
\hline $\begin{array}{l}\text { UNESCO Convention } \\
\text { against Discrimination in } \\
\text { Education, } 1960\end{array}$ & $\begin{array}{l}\text { Article 4: The States Parties to this Convention undertake } \\
\text { furthermore to formulate, develop and apply a national } \\
\text { policy which, by methods appropriate to the circumstances } \\
\text { and to national usage, will tend to promote equality of } \\
\text { opportunity and of treatment in the matter of education and } \\
\text { in particular: (a) To make primary education free and } \\
\text { compulsory; }\end{array}$ & Not ratified \\
\hline $\begin{array}{l}\text { International Convention } \\
\text { on the Elimination of All } \\
\text { Forms of Racial } \\
\text { Discrimination, } 1965\end{array}$ & $\begin{array}{l}\text { Article 5: States Parties undertake to prohibit and to } \\
\text { eliminate racial discrimination in all its forms and to } \\
\text { guarantee the right of everyone, without distinction as to } \\
\text { race, colour, or national or ethnic origin, to equality before } \\
\text { the law, notably in the enjoyment of the following rights: } \\
\text { (v) The right to education and training; }\end{array}$ & $\begin{array}{l}\text { Signed and } \\
\text { ratified in } \\
1966\end{array}$ \\
\hline $\begin{array}{l}\text { International Covenant } \\
\text { on Economic, Social and } \\
\text { Cultural Rights, } 1966\end{array}$ & $\begin{array}{l}\text { Article 13: The States Parties to the present Covenant } \\
\text { recognise that, with a view to achieving the full realisation } \\
\text { of this right: (a) Primary education shall be compulsory } \\
\text { and available free to all; }\end{array}$ & $\begin{array}{l}\text { Signed in } \\
2004 \text { and } \\
\text { ratified in } \\
2008\end{array}$ \\
\hline $\begin{array}{l}\text { Convention on the } \\
\text { Elimination of All Forms } \\
\text { of Discrimination against } \\
\text { Women, } 1979\end{array}$ & $\begin{array}{l}\text { Article 10: States Parties shall take all appropriate measures } \\
\text { to eliminate discrimination against women in order to } \\
\text { ensure to them equal rights with men in the field of } \\
\text { education and in particular to ensure, on a basis of equality } \\
\text { of men and women }\end{array}$ & $\begin{array}{l}\text { Ratified in } \\
1996\end{array}$ \\
\hline $\begin{array}{l}\text { Convention on the } \\
\text { Rights of the Child, } 1989\end{array}$ & $\begin{array}{l}\text { Article 1: States Parties recognise the right of the child to } \\
\text { education and with a view to achieving this right } \\
\text { progressively and on the basis of equal opportunity, they } \\
\text { shall, in particular: (a) Make primary education compulsory } \\
\text { and available free to all; }\end{array}$ & $\begin{array}{l}\text { Signed and } \\
\text { ratified in } \\
1990\end{array}$ \\
\hline $\begin{array}{l}\text { ILO Convention } 182 \text { on } \\
\text { Worst Forms of Child }\end{array}$ & $\begin{array}{l}\text { Article 7: (c) Ensure access to free basic education, and, } \\
\text { wherever possible and appropriate, vocational training, for }\end{array}$ & $\begin{array}{l}\text { Ratified in } \\
2011\end{array}$ \\
\hline
\end{tabular}


Table 8.3:

International Instruments on Free and Compulsory Education and Status of Pakistan

\begin{tabular}{|l|l}
\hline Labour, 1999 & all children removed from the worst forms of child labour;
\end{tabular}

Periodic reporting by State Parties is an established mechanism of implementation of international human rights treaties by the United Nations. ${ }^{180}$ Drinan views periodic reporting mechanism of the United Nations as one of the strongest weapons in its human rights arsenal through which it names and shames those who refuse to adhere to international human rights standards. ${ }^{181}$ Drinan argues that ultimately "this is the moral power which, more than laws or economic sanctions, will induce nations to follow the less travelled road that leads to democracy and equality." 182 Periodic reporting procedure as a form of monitoring of State's fulfilment of its international obligations has been questioned on its effectiveness and has a fair share of criticism but at minimum it has the advantage of reminding public authorities of deadlines and obligations to be met. ${ }^{183}$ Humphrey agrees and argues, "Periodic reporting is the implementation system with which the international community has had the longest, and probably the best, experience [among other tools]." ${ }^{184}$ Beitz also argues in defence of the periodic reporting that such "treaty monitoring systems seek to influence the behaviour of states by requiring them to give public accounts of their conduct." ${ }^{\text {, }} 85$ In case of Pakistan Human Rights Committee, Committee on Economic, Social and Cultural Rights, Committee on Elimination of Racial Discrimination, Committee on the Elimination of Discrimination

\footnotetext{
${ }^{180}$ Connor, C., "Recent Development: The United States' Second and Third Periodic Report to the United Nations Human Rights Committee," Harvard International Law Journal, Vol. 49, No. 2 (2008): 513

${ }^{181}$ Drinan, Robert F., The Mobilization of Shame: A World View of Human Rights (New Haven: Yale University Press, 2001)

${ }^{182}$ Ibid, 94

${ }^{183}$ Chazournes, L., "Monitoring, Supervision and Coordination of the Standard Setting Instrument of UNESCO," in Abdulqawi A. Yusuf (ed.) Normative Action in Education, Science and Culture: Essay in Commemoration of the Sixtieth Anniversary of UNESCO, pp. 51 - 72 (Leiden: Martinus Nijhoff, 2007): 60

${ }^{184}$ Humphrey, John P., "The International Bill of Rights: Scope and Implementation," William and Mary Law Review, Vol. 17, No. 3 (1976): 530

${ }^{185}$ Beitz, Charles R., The Idea of Human Rights (Oxford: Oxford University Press, 2009): 35
} 
Against Women, and the Committee on the Rights of the Child all have conventional mechanisms and require periodic reporting on the implementation of provisions of these treaties.

In build-up to the legislation on the Right to Free and Compulsory Education, a number of international treaties' instruments and national policies and plans of action highlighted the need for such legislative and policy actions. For instance, Pakistan submitted its third and fourth periodic report to the Committee on the Rights of the Child in 2009 wherein it stated that one of the measures needed to improve the quality of education was to make "primary education free and compulsory." ${ }^{186}$ Late in 2009, in its Concluding Observations in consideration of the reports submitted by Pakistan the Committee on the Rights of the Child recommends of setting-up "clear implementation plans for achieving universal free primary education by 2015 by raising the age of compulsory education to the minimum age for admission to employment," and shows its concern that "not all provinces have a compulsory education law and, where they exist, they are often not properly enforced." ${ }^{, 187}$ Similarly, in its fourth periodic report to the Committee on the Elimination of Discrimination against Women in 2009, Pakistan boasts Article 37 of the Constitution that provides for removing illiteracy and providing free and compulsory secondary education and a Compulsory School Attendance Bill introduced as a private member bill in 2008. The twentieth periodic report to the Committee on the Elimination of Racial Discrimination also refers to Article 37 of the Constitution as well as to the National Education Plan as one of the steps taken by the Government towards improving the quality of education in the country. ${ }^{188}$ One of the three

\footnotetext{
${ }^{186}$ Combined Third and Fourth Periodic Reports of Pakistan under Article 44.1(b) of the Convention on the Rights of the Child, March 19, 2009: 80

${ }^{187}$ Committee on the Rights of the Child, "Concluding Observations: Pakistan," October 15, 2009: 18

${ }^{188}$ Twentieth Periodic Reports of Pakistan under Article 9 of the International Convention on the Elimination of All Forms of Racial Discrimination, March 19 2008: 48
} 
goals set under National Plan of Action on Education for All were to ensure "that by 2015 all children with special emphasis on girls and children in difficult circumstances have access to and complete free and compulsory primary education of good quality." Under the National Plan of Action, the measures to be taken to achieve universal primary education for boys and girls were to be reinforced by legislation for compulsory primary education. ${ }^{189}$ The National Plan of Action is the outcome of the Dakar Framework for Action adopted by the World Education Forum in April 2000 in Senegal. One of the six goals set out under the framework is to ensure that "by 2015 all children, particularly girls, children in difficult circumstances and those belonging to ethnic minorities, have access to and complete free and compulsory primary education of good quality." Under Regional Framework for Action, the E-9 countries representing nine high population countries, including Pakistan, set one of its goals to make "changes in legislation to extend basic education and include education for all in policy statements. $" 190$ The National Education Policy, 1998-2010 also envisaged promulgation and enforcement of free and compulsory Primary Education Act in a phased manner. ${ }^{191}$ At around the same time, another trigger came from the neighbouring India. In 2009, India enacted The Right to Free and Compulsory Education as an act of the Parliament making education compulsory for children between 6 to 14 years.

In 2002, as per the directives of the Supreme Court of India, the Indian Government made an eighty-sixth amendment to the constitution and inserted a new Article 21A. The Article 21A provides for the right to education to every child in India between 6 to 14 years of age. Before 2002, the right to education in the Indian Constitution, much in the same lines as in

\footnotetext{
${ }^{189}$ Ministry of Education, National Plan of Action on Education for All 2001 - 2015 (Islamabad, Government of Pakistan, 20023): 94

${ }^{190}$ The Dakar Framework for Action adopted in the World Education Forum held from April 26 - 28, 2000 in Dakar, Senegal (Paris: UNESCO, 2000): 71

${ }^{191}$ Ministry of Education, Education for All: Mid Decade Assessment (Islamabad: Government of Pakistan, 2008): 54
} 
Pakistan, was incorporated as one of the directive principles of state policy, subject to economic resources and unenforceable by courts. ${ }^{192}$ The constitution making process and framing of the fundamental rights and freedoms both in India and Pakistan reflects their British heritage and are reflective of the 1945 United Nations Charter and the 1948 Universal Declaration of Human Rights. ${ }^{193}$ The first constitution of Pakistan promulgated in 1956 stated in Article 28 as a Directive Principles of State Policy, not enforceable by law, "remove illiteracy, and provide free and compulsory primary education within the minimum possible period. ${ }^{, 194}$ In the 1962 Constitution of Pakistan, the same was retained in Article 7 under the Principles of Policy as "illiteracy should be eliminated, and free and compulsory primary education should be provided for all, as soon as is practicable." In the 1973 Constitution of Pakistan, which lives to date, the same principle was reflected in Article 37(b) as "the State shall remove illiteracy and provide free and compulsory secondary education within minimum possible period." When in 2009 , the Indian Government enacted the Right to Free and Compulsory Education Act it not only had made education a fundamental right in 2002 it now had a comprehensive law providing statutory guidelines for its enforcement. For Pakistan, the opportunity came in 2008 when the coalition government of the time took upon the task of reversing amendments made to the 1973 Constitution of Pakistan under the military rules of General Zia and General Musharraf through which the office of the president had amassed considerable powers. The Eighteenth Amendment was enacted in 2010 and made more than 100 changes to the Constitution of Pakistan. Among limiting presidential powers, giving greater role to the parliament and the prime minister and clarifying composition and appointments of senior judiciary, it also entailed devolution of power and greater autonomy to provinces. The Eighteenth Amendment also added the Article 25A in the

${ }^{192}$ Ullah, A., "Right to Free and Compulsory Education in Pakistan after $18^{\text {th }}$ Constitutional Amendment," South Asian Studies, Vol. 28, No. 2 (2013): 332

${ }^{193}$ Ibid, 332

${ }^{194}$ The 1956 Constitution of Pakistan, Part 3 Directive Principles of State Policy, Article 28, Clause b 
chapter on the Fundamental Rights stipulating the responsibility of the State to "provide free and compulsory education to all children of the age of five to sixteen years in such manner as may be determined by law." "195 As the result of the Eighteenth Amendment to the 1973 Constitution of Pakistan, several subjects once dealt at the federal level, including education, are now the prerogatives of provinces. The reference to "may be determined by law" in Article 25A required provincial governments to formulate corresponding laws on provision of free and compulsory education.

The Federal Government first took the initiative and enacted The Right to Free and Compulsory Education Act in 2012 only applicable to the Islamabad Capital Territory and educational institutions that fall under its purview. The most recent report submitted by Pakistan to the Committee on the Rights of the Child refers to both Article 25A and the Act on the Right to Free and Compulsory Education as among the measures taken by the State to ensure the rights of the children in Pakistan. ${ }^{196}$ In particular, enactment of the Right to Free and Compulsory Education Act, 2012 coincided with a visit of the former British Prime Minister Gordon Brown in the capacity of United Nations Special Envoy on Education to Pakistan in November to commemorate Malala Day. On November 10, he met the-then President Asif Ali Zardari and presented him a petition signed by over one million people in support of the cause of 'education for all' and conveyed United Nations Secretary General's Ban Ki-Moon aspirations to continue building “on the momentum of UN's Education First initiative and show that education is a right of everyone, and not a privilege for a few." $" 197$ Center for Education and Consciousness, a nongovernmental organisation working in Pakistan, which had spearheaded the One Million Signature campaign, gives credence to

\footnotetext{
195 Article 25A, the 1973 Constitution of Pakistan

${ }^{196}$ Fifth Periodic Reports of Pakistan under Article 44.1(b) of the Convention on the Rights of the Child, May 23, 2014: 10

197 The Express Tribune, "November 10 to be Celebrated as Malala Day," November 9, 2012
} 
Gordon Brown visit because of which the ratification of the Right to Free and Compulsory Education Act 2012 by the National Assembly for Islamabad Capital territory could become possible. ${ }^{198}$ It is important to underscore that as a British Prime Minister until 2010, Gordon Brown had made two visits to Pakistan in December 2008 and April 2009 and hosted his Pakistani counterparts at the 10-Downing Street in the months of May, August and December in 2009. In April 2009, Gordon Brown gave a speech to the House of Commons in which he outlines his Afghanistan-Pakistan Strategy whereby Britain's development assistance to Pakistan become their second-largest worldwide providing $£ 665 \mathrm{~m}$ in assistance over the next four years with refocus on education spending. ${ }^{199}$ This assistance, among other initiatives, also launched two of the biggest ever advocacy campaigns [in terms of both duration and volume], namely Zara Sochiye and Alif Ailaan, in the history of Pakistan aimed at bringing reforms in the education sector.

By late 2012, enough momentum had been built through these various ideational forces which eventually culminated into passing of the legislation on the Right to Free and Compulsory Education.

\begin{tabular}{|l|l|}
\hline \multicolumn{2}{|l|}{$\begin{array}{l}\text { Table 8.4: } \\
\text { Timeline to the Right to Free and Compulsory Education Act, } 2012 \text { in Pakistan }\end{array}$} \\
\hline 1947 & $\begin{array}{l}\text { Soon after independence, All-Pakistan Education Conference was held that made three basic } \\
\text { recommendations including making elementary education free and compulsory. }\end{array}$ \\
\hline 1948 & $\begin{array}{l}\text { The Universal Declaration of Human Rights was passed with Article } 26 \text { explicitly declaring } \\
\text { education as the right of everyone. }\end{array}$ \\
\hline 1956 & The 1956 Constitution of Pakistan made free and compulsory primary education as one of \\
\hline
\end{tabular}

\footnotetext{
${ }^{198}$ Right to Education Leaflet 2013, retrieved from http://rtepakistan.org/wpcontent/uploads/2013/04/RTELeaflet-2013.pdf on November 8, 2014

${ }^{199}$ Shackle, S., "What is Our Counterterrorism Strategy in Pakistan?" New Statesman, January 21, 2010

${ }^{200}$ Khan, Akhtar H., "Education in Pakistan: Fifty Years of Neglect," The Pakistan Development Review, Vol. 36, No. 4 (1997): 648
} 
Table 8.4:

Timeline to the Right to Free and Compulsory Education Act, 2012 in Pakistan

\begin{tabular}{|c|c|}
\hline & the Directive Principles of State Policy. \\
\hline 1959 & $\begin{array}{l}\text { A National Commission on Education was established that aimed at making education } \\
\text { compulsory for age group } 6 \text { to } 11 \text { within } 10 \text { years time. }{ }^{201}\end{array}$ \\
\hline 1970 & $\begin{array}{l}\text { The first education policy was announced reaffirming the commitment "to the objective of } \\
\text { universal elementary education" accepting it as a "basic principle of State Policy in the } \\
\text { Constitutions of } 1956 \text { and 1962", and proposed ... compulsory, universal and free primary } \\
\text { education as a target for 1980."202 }\end{array}$ \\
\hline 1972 & $\begin{array}{l}\text { Education Policy } 1972 \text { - } 1980 \text { was announced declaring "education will be made free and } \\
\text { universal up to Class X for all children throughout the country."203 }\end{array}$ \\
\hline 1973 & $\begin{array}{l}\text { The } 1973 \text { Constitution of Pakistan retained free and compulsory primary education of the } \\
1956 \text { and } 1962 \text { Constitutions as one of the Directive Principles of State Policy. }\end{array}$ \\
\hline 1979 & $\begin{array}{l}\text { Education Policy } 1979 \text { was announced that set out the goal "to provide minimum acceptable } \\
\text { level of functional literacy and fundamental education to all citizens of the country."204 }\end{array}$ \\
\hline 1985 & $\begin{array}{l}\text { The Literacy Ordinance was promulgated that for the first time made provision of passport, } \\
\text { driving and arm licences and employment with the local body or in an establishment or } \\
\text { institution under the control of Federal Government only to a literate person. }\end{array}$ \\
\hline 1990 & $\begin{array}{l}\text { Signed and ratified Convention on the Rights of the Child, which categorically asks State to } \\
\text { make primary education compulsory and available free to all. It is pertinent to note that at the } \\
\text { time Pakistan had not signed other human rights treaties, namely International Covenant on } \\
\text { Civil and Political Rights, Convention on the Elimination of All Forms of Discrimination } \\
\text { Against Women and International Covenant on Economic, Social and Cultural Rights. }\end{array}$ \\
\hline 1990 & $\begin{array}{l}\text { The World Conference on Education For All was held in Thailand, attended by Pakistani } \\
\text { delegation, which issued a World Declaration on Education for All reaffirming the notion of } \\
\text { education as a fundamental human right. }\end{array}$ \\
\hline 1992 & $\begin{array}{l}\text { As per the goals set in the World Conference on Education for All, National Education } \\
\text { Policy was introduced that set the objective of making the primary education compulsory } \\
\text { and free to achieve universal enrolment in ten years time. }\end{array}$ \\
\hline 1994 & $\begin{array}{l}\text { During this period, laws on compulsory education were passed in Punjab, NWFP [now } \\
\text { called Khyber Pakhtunkhwa], Sindh and for the Islamabad Capital Territory, namely The }\end{array}$ \\
\hline
\end{tabular}

${ }^{201}$ Ibid, 649

202 Bengali, K., "History of Educational Policy Making and Planning in Pakistan," Working Paper

Series \# 40 (Islamabad: Sustainable Development Policy Institute, 1999): 6

${ }^{203}$ Ibid, 7

${ }^{204}$ Ministry of Education, Development of Education in Pakistan 1990 - 1992: Country Report for the 43rd Session of International Conference on Education (Islamabad: Government of Pakistan, 1992): 4 


\begin{tabular}{|c|c|}
\hline 2002 & $\begin{array}{l}\text { Punjab Compulsory Primary Education Act, 1994; The NWFP Compulsory Primary } \\
\text { Education Act, 1996; The Sindh Compulsory Primary Education Ordinance, 2001; The ICT } \\
\text { Compulsory Primary Education Ordinance, } 2002 .\end{array}$ \\
\hline 1998 & $\begin{array}{l}\text { The National Education Policy } 1998-2010 \text { was launched which stated that primary } \\
\text { education will be made compulsory through legislation and will effectively be implemented } \\
\text { and recalled provisions made under the } 1948 \text { Universal Declaration of Human Rights and the } \\
1989 \text { Convention on the Rights of the Child that it is State's duty ensure that primary } \\
\text { education is free and compulsory. }{ }^{205}\end{array}$ \\
\hline 2000 & $\begin{array}{l}\text { Ten year later as targets set in the World Conference on Education for All remained } \\
\text { unachieved, World Education Forum was held in Dakar, Senegal and Pakistan signed to its } \\
\text { goal for achieving Education for All by year } 2015 \text {. }\end{array}$ \\
\hline 2001 & $\begin{array}{l}\text { Education Sector Reforms program was initiated and National Plan of Action for Education } \\
\text { for All was developed to realise Education for All goals by the year } 2015 \text {. }\end{array}$ \\
\hline 2009 & $\begin{array}{l}\text { In 2002, India had made education a fundamental right from a directive principle of state } \\
\text { policy and in } 2009 \text { enacted The Right to Free and Compulsory Education as an act of the } \\
\text { Parliament making education compulsory for children between } 6 \text { to } 14 \text { years. }\end{array}$ \\
\hline 2010 & $\begin{array}{l}\text { The Eighteenth Amendment was made to the } 1973 \text { Constitution of Pakistan, which included } \\
\text { Article } 25 \mathrm{~A} \text { that made responsibility of the State to provide free and compulsory education } \\
\text { to all children of the age of five to sixteen years. }\end{array}$ \\
\hline 2012 & $\begin{array}{l}\text { On October 9, } 2012 \text { Malala Yousafzai was shot in an assassination attempt that sparked } \\
\text { international outrage and brought the issue of education in general and specifically of girls } \\
\text { education in Pakistan on the top of the policy agenda. }\end{array}$ \\
\hline 2012 & $\begin{array}{l}\text { The Right to Free and Compulsory Education Act was passed and received assent of the } \\
\text { President and made into a law. }\end{array}$ \\
\hline
\end{tabular}

In the context of Pakistan and in comparison to the other two bills discussed, the ideational traces for the Right to Free and Compulsory Education Act goes further back and are found in colonial past and British constitutional heritage. All three constitutions of 1956, 1962 and 1973 made free and compulsory education as one of the directive principles of state policy while almost all education policies aspired to reach to this goal in a foreseeable future. The

${ }^{205}$ Bengali, K, 1996: 24 
force, however, which continue demanding a legislative response at the front came through the international human rights treaties under the United Nations and its various specialised agencies. The momentum started building up during the last decade of the twentieth century with Pakistan having signed and ratified the Convention on the Rights of the Child. For instance, the first Periodic Report by Pakistan in 1993 to the Committee on the Rights of the Child refers to a resolution passed by the Senate in its efforts to universalise children's education urging "Government to ensure compulsory and free education to all its citizens at the primary level," and that "The education departments of four provinces have been requested to initiate necessary steps/action for the implementation of the resolution." ${ }^{206}$ The third and fourth Periodic Reports, submitted together in 2009, stated as one of the achievements that though "national compulsory primary education law cannot be devised as this action is done at the provincial level," however "three of the four provinces, Federally Administered Areas and the Islamabad Capital Territory (ICT) [all] have compulsory primary education laws." 207 So much so, the 2008 Mid-Decade Country Assessment Report on Education by Ministry of Education stated that there "are no legislative hindrances [left now] for children in access to education [as] all federating units have made primary education free and compulsory." ${ }^{208}$ This report was published only two years before the Eighteenth Amendment to the Constitution that made free and compulsory education a fundamental right of citizens of Pakistan and one of the duties of the state. The Article 25A thus marks the "first significant controversy” for the Right to Free and Compulsory Education Act, 2012 recreating the need for such legislative interventions when previously they were reported to have been sufficed. Interestingly, while the ideational roots for the Right to Free and

\footnotetext{
${ }^{206}$ First Periodic Reports of Pakistan under Article 44.1(b) of the Convention on the Rights of the Child, May 28, 1993: 31

${ }^{207}$ Third and Fourth Periodic Reports of Pakistan under Article 44.1(b) of the Convention on the Rights of the Child, March 19, 2013: 70

${ }^{208}$ Ministry of Education, Education for All: Mid Decade Assessment Pakistan Country Report 2008 (Islamabad, Government of Pakistan, 2008): 112
} 
Compulsory Education Act, 2012 are the deepest, the time between the "first significant controversy" and the "last significant controversy" is the shortest spanning only a two years period. During these two years, the bilateral role of the British Government is significant in the education sector with triggers coming in various forms and formats, both from inside Pakistan with the assassination attempt on Malala Yousafzai as well as from the outside with the Indian Government having pass a national act on the Right to Free and Compulsory Education Act. The main ideational force thus constituted of the international community, with the human rights treaties serving the bedrock, engaging though multilateral and bilateral means and shaping education sector policies and legislations in Pakistan.

\subsection{2: UNDERLYING IDEATIONAL DIMENSIONS TO THE FREE AND COMPULSORY EDUCATION ACT IN PAKISTAN}

In order to study the underlying ideational dimensions to the Right to Free and Compulsory Education Act, 2012, a total of 11 in-depth interviews were conducted. From the United Nations, Ms. Khalida Ahmad represented UNICEF and Mr. Arshad Saeed Khan provided insights on the behalf of UNESCO. From the donor community, Mr. Atif Rafique was interviewed to ascertain the role of UK Government's Department for International Development and Dr. Faisal Bari for the role of Open Society Foundation. Both the Senator SM Zafar who had tabled the legislation in the Senate and the parliamentarian Ms. Yasmeen Rehman who had moved the bill in the national assembly were also interviewed. From the side of bureaucracy, Mr. Khalid Hanif, who is the Additional Secretary for the Federal Ministry of Education and Trainings, was interviewed. Mr. Qamar Zaman Chaudhary, who was the Federal Secretary for Education at the time the legislation, declined the interview. However, the then Federal Ministry for Education, Mr. Sheikh Waqas Akram, was 
interviewed in detail. Ms. Mehnaz Aziz of Children's Global Network, Mosharraf Zaidi of Alif Ailan and Mr. Ahmad Ali of Institute of Social and Policy Studies represented civil society organisations. Please see table 7.7 for further description of all the interviewees.

There is a general agreement among the respondents that the insertion of Article $25 \mathrm{~A}$ on right to education, as a result of the Eighteenth Amendment to the 1973 Constitution, is a cornerstone for the legislation on free and compulsory education. Ms. Yasmeen Rehman, who was the member of the parliament from the ruling Pakistan Peoples Party and had tabled the bill, elucidates the same "I believe the 25A was the main trigger." Arshad Saeed Khan who was the Senior National Specialist with UNESCO agrees, "This bill had two stages; the first was to have the Article 25A added into the Constitution...." Other respondents also spoke of Article 25A in similar lines:

"It was a constitutional requirement, as you added the Article $25 \mathrm{~A}$ into the

Constitution so it had become an obligation on the State... [Ahmed Ali,

Research Fellow, Institute of Social and Policy Studies].

"It started with the eighteenth constitutional amendment [25A]; I was member of the review committee... and we took advantage from it. "[SM Zafar, Former Senator, Pakistan Muslim League - Quaid]

"The day the article got inserted into the Constitution, the debate also started...and...people started discussing education as their right." [Ahmed Ali, Research Fellow, Institute of Social and Policy Studies]. 
However, many of the respondents spoke of the unexpectedness over the insertion of the Article 25A into the Constitution. There was no visible or otherwise movement or specific demand from any sections of the society for such a commitment. Ahmed Ali, who is the Research Fellow at the Institute of Social and Policy Studies calls it a "mystery," and explains, "we have gone through the minutes of the meetings of the Constitutional Commission, we have looked at the applications filed to the Commission and its responses and when the Commission solicited inputs from the citizens and you will be surprised there was no such demand [for Article 25A]...if you compare this with the Right to Education Bill passed in India there was a huge crowd outside the legislature standing and demanding the right to education but in this particular case you will be surprised that not even a single vocal or a written demand was there." Other respondents also agree:

"The surprise for me [during the process of legislating for the free and compulsory education bill] was to have the $25 \mathrm{~A}$ inserted into the Constitution." [Arshad Saeed Khan, Senior National Specialist, UNESCO]

"25A is the least discussed provision of the Eighteenth Amendment. Most of the discussion revolved around other bigger political issues, such as presidential power." [Dr. Faisal Bari, Senior Advisor, Open Society Foundation]

Arshad Saeed Khan [Senior National Specialist, UNESCO] believes that perhaps parliamentarians were not cognizant of the implications of Article 25A, "People perhaps let it made part of the Constitution thinking that it does not mean a lot and carry not much weight." From the interviews, it became apparent that insertion of Article 25A into the 
Constitution through the Eighteenth Amendment was mainly the result of efforts of one person - Senator SM Zafar. Ahmad Ali [Research Fellow, Institute of Social and Policy Studies] says, "Article 25A is the result of one person only - SM Zafar. The person who in fact introduced this in the Eighteenth Constitutional Amendment and also the bill that eventually became a law at the Federal level was SM Zafar.” Senator SM Zafar himself spoke of his involvement in Article 25A:

\begin{abstract}
"From my party side, I moved an amendment on education. I was also at the time Chairman of the Standing Committee on Education, there was some debate that whether it can become a fundamental right, and I said that education is now the most basic thing one needs in life. So when I moved this amendment fortunately most of the members accepted it and the language was very clear.” [SM Zafar, Former Senator, Pakistan Muslim League - Quaid]
\end{abstract}

Arshad Saeed Khan [Senior National Specialist, UNESCO] believes, "If people like SM Zafar were not there it would have become very difficult." The choice of Senator SM Zafar to champion the cause of education for civil society organisations in the policymaking corridors seems an obvious one. He has been Chairman of the Human Rights Commission of Pakistan, also the Chancellors of Hamdard University and was at the time the Chairman of Senate's Standing Committee on Education. More so, as Arshad Saeed Khan [Senior National Specialist, UNESCO] encapsulates why involvement of SM Zafar made sense, "Senators are easier to get hold of, they don't have their constituency to worry about. We involved Senator SM Zafar, a highly respected figure, and invited him to our discussions and he was the Chairman of the Senate's Standing Committee on Education at the time." Senator SM Zafar himself agrees that his background in education made him interested in the 
legislation, "I otherwise was very interested; I have been the Chancellor of Hamdard University. So it is in my background and so we moved this bill."

Senator SM Zafar recalls the time when he presented the bill in the Senate and he could not pursue it further as his term ended, "the bill was presented by me as a private member, from there it was referred to the Standing Committee on Education, and it brought it to the Senate and it took a long time. And by the time I was able to bring it back to the Senate my third term had ended. We had to find another private member to continue with it. So it took a long time there and so when it went to the National Assembly, somebody had to be selected there." From the time the Article 25A was inserted into the Constitution to when the legislation was passed took hardly two years. Khalid Ahmad [Education Officer, UNICEF] believes once the bill was tabled it got passed hurriedly due to the international pressure, "The bill was passed hurriedly...international community was looking at them and asking ‘why aren't you [Government of Pakistan] doing your job.” Even Yasmeen Rehman [Former Member National Assembly, Pakistan Peoples Party], who had tabled the bill in the parliament, spoke of her surprise that in no time the bill was passed, "The surprise for me was that this bill was instantly passed and became legislation." She and others interviewed believe that the visit of Gordon Brown has a critical role inhere:

"Gordon Brown visited in last November in 2012, and he met with ministers and the Prime Minister and asked that something needs to be done [for education] urgently, and one thing that could have been done immediately was passing the legislation." [Ms. Khalida Ahmad, Education Officer, UNICEF] 
There was high-level strategic dialogue with the UK in the last few months of the Gordon Brown and it would have been a nice thing to present internationally. [Mr. Atif Rafiq, Education Advisor, DFID]

\footnotetext{
"What had happened, the bill was sitting in the National Assembly and we feared that it would lapse. Gordon Brown was visiting Pakistan during that time and the Malala incident had also happened. These two incidents also provided impetus to passing of the legislation." [Arshad Saeed Khan, Senior National Specialist, UNESCO]
}

Khalid Hanif, who is the Additional Secretary at the Federal Ministry of Education and Trainings recalls, "This bill was enacted right before the second visit of Gordon Brown and during that time President [Asif Ali Zardari] was also scheduled to visit UNESCO's headquarter. Arshad Saeed Khan [Senior National Specialist, UNESCO] also believes that "Once the bill had reached the assembly... the bill was passed due to the visit of Gordon Brown." Khalida Ahmad [Education Officer, UNICEF] believes that after the visit, "more resources were deployed [towards education]. However, respondents also did not discount the normative base that had established over the past many decades.

\footnotetext{
"Historically, there has been a conversation in Pakistan that primary education should be free and before the amendment it was part of our principles but stated not as a basic right. In provinces, however, there were laws on primary education but they were not implemented." [Dr. Faisal Bari, Senior Advisor, Open Society Foundation]
} 
"I believe the impetus was also provided by the 1973 Constitution, its article $37 b$ under Principles of Policy that contained that State remove illiteracy and provide free and compulsory secondary education within minimum possible period. " [Arshad Saeed Khan, Senior National Specialist, UNESCO]

Nevertheless, the timing of the law was primarily defined by a strategy of appeasement. Atif Rafiq [Education Advisor, DFID] agrees that the legislation was "result of influential politicians who wanted to signal to the international world that the federal government is serious about education.” For Atif Rafiq [Education Advisor, DFID] such gestures encourages international donors, i.e. Department for International Development, as it shows political will "to justify a huge investment needed in Pakistan for the next five years." Respondents also opinionated that similar activism in the region must have also had an impact on the legislation in Pakistan.

"There is pressure on our governments to adhere to what is happening in the region and as per the global reality, a similar act is also passed in India. We took the influence from our region. [Mehnaz Aziz, Chief Executive Officer, Children's Global Network]

"The biggest example I had was from India in form of their Eighty-sixth Amendment passed in 2003, I used to show that to everyone on PowerPoint that this is the law passed in 2003 and their indicators have since improved so why cannot we do the same [Arshad Saeed Khan, Senior National Specialist, UNESCO]. 
This coupled with international instruments, i.e. conventions and treaties, have had also a role to play in bring this issue to the fore.

\author{
It's very embarrassing for the Country and the parliamentarians too when \\ reports come and Pakistan is lumped together with African countries in \\ respect to status of education in Pakistan." [Khalida Ahmad, Education \\ Officer, UNICEF]
}

It is true that the insertion of Article 25A and the subsequent legislation has a lot of similarities to the case of India, and the respondents pointed to the same:

"When ever we pass some legislation, some how or the other we always look towards our neighbours, especially India and Bangladesh, and we do keep an eye on their legislative businesses." [Yasmeen Rehman, Former Member National Assembly, Pakistan Peoples Party]

“We had reviewed best practices of India and Sri Lanka, so yes we looked around." [Khalida Ahmad, Education Officer, UNICEF]

\footnotetext{
"We advertised it twice [for drafting the legislation], the first time we did not receive any quote and even the second time no one applied. We then took a lot of help from a similar act in India. [Arshad Saeed Khan, Senior National Specialist, UNESCO]
} 
“The bill isn't much different to the Indian legislation. We have had a lot of help from that piece of legislation." [Arshad Saeed Khan, Senior National Specialist, UNESCO]

It is almost exactly the same that the Indian Constitution has, the only difference is that the change the age from 14 years to 16 years. [Dr. Faisal Bari, Senior Advisor, Open Society Foundation]

The drafting of the legislation, thus, took a lot of references from similar legislative work in India and other countries of the region. Interestingly, the Ministry of Education was completely detached from both the insertion of Article 25A and subsequent legislation on free and compulsory education. Mehnaz Aziz [Chief Executive Officer, Children's Global Network] claims, "even parliamentarians had not been involved... and the technical assistance came from UNESCO mainly. Sheikh Waqas Akram, who was the Federal Minister of Education at the time, confesses:

"I came to know about this bill in 2012 when Yasmeen Rehman, who represented PPP, presented this bill as a Private Member...this should have been tabled by the government in the first place. [Sheikh Waqas Akram, Federal Minister for Education]

The Federal Minister and the Bureaucracy, in their statements, seemed unhappy with the legislation. Sheikh Waqas Akram [Federal Minister for Education and Formerly Member of Pakistan Muslim League - Quaid] says, "It should have been the responsibility of the Ministry to do that. But it came through a private member.” Khalid Hanif [Additional 
Secretary, Federal Ministry of Education and Trainings] thinks, "There was no thought behind how this bill is going to be implemented." Ironically, members of the civil society agree:

\author{
"I asked the Government of Khyber Pakhtunkhwa of their intentions about the \\ bill [referring to the Free and Compulsory Education Act for ICT] and they \\ said that shortfall of finances is such that we cannot do it. Now anybody \\ thinking seriously about this would have similar reaction. [Mehnaz Aziz, Chief \\ Executive Officer, Children's Global Network]
}

Mehnaz Aziz [Chief Executive Officer, Children's' Global Network] believes that it was merely "tick mark that you have this legislation but its technical dimensions were not looked into.” Khalid Hanif [Additional Secretary, Federal Ministry of Education and Training] speaks of the legislation in similar lines, "It is dilemma of our country, we get very beautifully drafted rules and regulation but they are not implemented. They passed the legislation in a single day under pressure and did not pay much attention how it is going to be implemented. However, SM Zafar [Senator, Pakistan Muslim League - Quaid] thinks that even "when the pressure comes from USA or UK, I will welcome it if it is for education or health."

With the legislation having applicability only in the Capital Territory, respondents opinionated that implementation of the law must have been considered otherwise this law would have been passed in other provinces and regions too. As it was only a legislation to showcase government's commitment towards the cause of education, not only the law was made toothless it was also restricted to ICT region only: 
"Compared to the big provinces obviously ICT is very small so they don't have that much to lose from a legislation. They have a semblance of an infrastructure and they are deputed in each area that are not difficult to reach and they can make a good start towards implementing it and probably they can also find the money. [Atif Rafiq, Education Advisor, DFID]

If Gordon Brown had come to Punjab and asked for such a law, they would have not done this. They know that their voter is very smart and if they pass such a law then the people will demand for services that they cannot provide. It could be the reason that they wanted to showcase this bill for his [Gordon Brown] visit. [Mehnaz Aziz]

"It is a toothless bill. There is a clause in this law that requires that all the private schools should enrol a certain percentage of students in every class free of any fees. Have you seen this happening anywhere?" [Ahmed Ali, Research Fellow, Institute of Social and Policy Studies].

Atif Rafiq [Education Advisor, DFID] believes that it is "absolutely essential that some signal [of government's commitment] is given [to the international community] because of the scale of the problem. In Faisal Bari's [Senior Advisor, Open Society Foundation] opinion at least activists like him "can go to the Supreme Court and claim that provision of education is the responsibility of the State and not being provided." Mehnaz Aziz [Chief Executive Officer, Children's Global Network] thinks that now the bill has put the government "between the rock and the hard place because ...now things have to be improved." The 
element of contestation, if there was any, came primarily from the bureaucracy. Arshad Saeed Khan [Senior National Specialists, UNESCO] elucidates the same, "Bureaucracy has such a mind-set that after looking at every proposed bill their first question is from where will the money come.” SM Zafar [Senator, Pakistan Muslim League - Quaid] agrees, "In case of education, the bureaucracy showed reluctance, they had put hurdles."

The Article 25A of the 1973 Constitution of Pakistan, inserted through the Eighteenth Amendment in 2010 can be considered the main reference point for the Right to Free and Compulsory Education Act, 2012. Interviews confirm that the Review Committee tasked with drafting the Eighteenth Amendment did not delve into much discussion on the proposed Article 25A and it was added to the package mainly because of the initiative of Senator SM Zafar. Perhaps the last section of the Article 25A that left the determination of free and compulsory education to all children "as may be determined by law," allowed members of the Review Committee to not contest or debate otherwise its insertion. The main reason the Eighteenth Amendment was enacted was to reverse amendments made to the Constitution under the military rules of General Zia ul Haq and General Pervez Musharraf through which the office of the president had amassed considerable powers. It enacted more than 100 changes to the Constitution, including devolution of power and greater autonomy to provinces. While these areas were hotly debated and contested, declaration of education as a fundamental right did not gain any limelight. Once the Article 25A was made part of the Constitution, the civil society saw this as an opportunity to further the agenda of provision of free and compulsory education. Arshad Khan [Senior National Specialist] recalls being invited to the meeting of the Standing Committee by Senator SM Zafar in which he briefed the members on the status of education and offered UNESCO's technical assistance through provision of legal experts for drafting law. In drafting and during the process of legislation, 
ask Khalid Hanif [Additional Secretary, Federal Ministry of Education and Trainings testifies, "UNESCO and UNICEF played a very crucial role and they were at the forefront." It becomes clear from the interviews that it was mainly because of the international pressure and the expectations upon the government of Pakistan because of its commitments the bill was passed. The role of Gordon Brown is crucial whose visit to Pakistan as a UN special envoy for global education was the main catalyst because of which the legislation passed. In July 2012, the Secretary General Ban Ki-moon appointed Mr. Brown as UN Special Envoy for Global Education. In October 2012 a month before his scheduled visit to Pakistan, $\mathrm{Mr}$ Brown had said, "I have asked Pakistan's President [Asif Ali] Zardari to pledge that Malala's suffering will not be in vain. In response, he has invited me to lead a delegation of education leaders to visit him in Pakistan in November to talk about how he can improve opportunities for children," His spokesperson further added that the aim Mr. Brown's visit to Pakistan is to "to get governments, international non-governmental organisations and businesses to agree practical proposals to turn the "promise of universal education into reality," and that "in recent talks, President Zardari has agreed that there should be a plan to get the five million Pakistani girls and boys presently not schooled into education." ${ }^{, 209}$ The legislation was passed a month later in December 2012 and two months later President Zardari was on an official visit to UK. The preceding discussion elucidates almost negligible involvement of public, in forms of any interest groups, in formulation of the policy agenda and similarly the legislation also lacked the element of contestation. The scope of the legislation was more of a symbolic nature and shaped and decided in the background of policy formulation

\footnotetext{
${ }^{209}$ BBC News, "Ex-PM Gordon Brown speaks out on Pakistan schools," http://www.bbc.com/news/uk-19911961
} 


\section{5: IDEATIONAL POLICY MAKING IN PAKISTAN}

In Chapter-4, this research postulated four key claims to support the central thesis that ideational institutionalism has the capacity to inform an endogenous account of complex institutional evolution, continuation, adaptation, and innovation. For this purpose, the research relied on the overarching theoretical paradigm of ideational institutionalism that, unlike other three established schools of new institutionalism, posits a dynamic agent-centred approach in which the actors are strategic and socialised, while the institutions are both constraining and enabling constructs. The research applied the methodological approach of 'policy-as-discourse' that sees public policy process and its outcomes embedded in a web of social meanings produced and reproduced through discursive practices and shaped through socially interpreted understandings and meanings. ${ }^{210}$ This essentially involves complex ideational processes whereby policymakers assemble and assess information and construct pictures of reality. ${ }^{211}$ In order to gauge the strength of the central claim, three social legislations are studied from the perspective to assess whether ideas, conceived as the basis for policy decisions, have an affect on the course of the policy process, the public policy solutions and the eventual policy outcome. By studying the three legislations, the research explored the interplay of myriad of ideas that have cognitive, normative and material dimensions in a political system broadly consisting of public contestation and inclusiveness that shapes and decides the policy agenda. The research further investigated whether the policy actors in a particular political system used these ideas, to interpret and construct their situation, which in returned shaped their interest, preferences and identities. Finally, the research also explored whether policy decisions are reflective more of a dominant set of

\footnotetext{
${ }^{210}$ Fischer F., 2003: 4

${ }^{211}$ Bell, S., "The Power of Ideas: The Ideational Shaping of the Structural Power of Business," International Studies Quarterly, Vol. 56 (2012): 671
} 
ideas, either in the background or foreground of the policy debate. Based on the preceding discussion, following set of findings are derived to substantiate the central thesis of this research:

1. In all three public polices, actors were oriented subjectively towards their environment and their desires, preferences, and motivations were irredeemably ideational, i.e. education is the right of the children, selling/buying body organs is unethical and immoral, women have equal rights...

In all three legislations, both globally and in the perspective of Pakistan, actors orientation to policy issues, i.e. the right of children to free and compulsory education, or the right of women to work and their right against discriminatory practice, or the right of human dignity, were not contextually given facts but constructed over many years and were irredeemably ideational. In this respect, the Universal Declaration of Human Rights and subsequent international conventions, treaties and covenants have played a pivotal role. Specifically, in the case of the Pakistan the insertion of Article 25A on free and compulsory education can be traced back to Country's colonial past and its constitutional history, while the Free and Compulsory Education Act, 2012 itself originated only after the insertion of Article 25A. The Protection Against Harassment of Women at Workplace Act, 2010 originated from the creation of a local advocacy group called 'Alliance Against Sexual Harassment,' that not only defined the problem but also provided the solution in form of the proposed legislation. The Transplantation of Human Organ and Tissue Act, 2009 has its roots when the renal transplantation started in Pakistan in 1979 and when by 1990s the practice of organ transplantation in neighbouring India was fast becoming commercialised. This is also the focus of the 'policy-as-discourse' theorists who see policies not being framed in response to 
existing conditions and problems, "but more as a discourse in which both problems and solutions are created". ${ }^{212}$

2. Actors, studied in the three policies, were strategic and sought to realise policy goals while relying upon their subjective perceptions of the context and applying multiple levels of criteria, i.e. material, normative and cognitive, for favouring certain strategies over others.

The cases confirm that both the actors outside the formal legislative arenas and those tasked with the legislation were strategic and relied upon multiple levels of criteria for strategising policymaking. In case of the Protection against Harassment of Women at the Workplace Act, 2010, Dr. Fauzia Saeed, who formed Alliance Against Sexual Harassment that advocated for policy reforms to address the issue of sexual harassment, herself had been a victim of sexual harassment. Already well-established ideational foundation on rights of women and against discriminatory practices against women in employment also helped AASHA and to only press for legislation when there is increasing women representation in the legislature, together with strong women personalities in key ministries and parliamentary committees further helped their cause. For the Transplantation of Human Organ and Tissues Act, 2009, the orientation of the medical community, led by Professor Dr. Adibul Hassan Rizvi, was primarily through their exposure to international best practices and ethical expectations, the reason why SIUT prohibited unrelated commercial transplants and 'transplant tourism. However, in order to rally popular support to bring an end to commercial organ transplantation, SIUT and Transplantation Society relied heavily on the use of media to generate political pressure and to raise public awareness by holding several seminars,

\footnotetext{
${ }^{212}$ Goodwin, N., "Governmentality in the Queensland Department of Education: Policies and the Management of Schools," Discourse, Vol. 17, No. 1 (1996): 67
} 
symposia and press conferences that highlighted the exploitation of paid donors and called on the government to enact a transplantation law. In academic debates, it was essentially the absence of a deceased donor program coupled with shortage of organs in Pakistan, greater efficacy of transplantation from a related living donor of related donor, i.e. better match and improved graft survival rate and improvement in transplant expertise that had led to unrelated commercial transplants. Finally, in case of the Right to Free and Compulsory Education Act, 2012, in build-up to the legislation, the reporting requirements of a number of international treaties, instruments and national policies and plans of actions highlighting the need for policy action had build up considerable pressure on the government. This coincided with the visit of former British Prime Minister in the capacity of United Nations Special Envoy on Education who was asked to specifically press upon the need for visible actions on part of Pakistan to show that education is a right of everyone and not a privilege for a few. The insertion of Article 25A further provided impetus to the international community, especially UNICEF and UNESCO, to demand from the state of Pakistan to translate their constitutional obligations into actionable polices.

3. Actors used ideas of various kinds and their policy preferences and decisions were reflection of and favoured certain set of dominant ideational constructs in relation to others.

The analysis show that dominant ideational construct in the public domain in all three legislative policies is based on the normative dimension but the timing, which defined the 'last significant controversy', is based on the material dimension. In case of the Protection Against Harassment of Women at the Workplace Act, 2010, the timing of the bill was defined by the expectation attached to the third term of the Pakistan Peoples Party as pro- 
women as well as the sizeable and unprecedented representation of women in the legislature expected to take up women issues. As a result, the Minister for Women Development, who herself was a member of a strong women caucus, agreed to present the proposed legislations as a government bill, which was steered and drafted by a civil society movement. In case of the Transplantation of Human Organs and Tissues Act, 2009, it was because of the suo motu notice taken by the Supreme Court of Pakistan advising the Government to regulate the organ transplantation that compelled President General Musharraf to promulgate an ordinance in this effect, and again referral of a total of 34 ordinances enacted by President General Pervez Musharraf, including the one on organ transplantation, to the civilian government for revalidation in 120 days. As for the Right to Free Compulsory Education Act, 2012, the visit of Gordon Brown to Pakistan and the subsequent visit of President Asif Ali Zardari to the United Kingdom, together with the demand of visible action on part of the Government of Pakistan on universalisation of education for release of funds, played a pivotal role.

\section{Ideational constructs that are well institutionalised had a smaller temporal dimension} from the 'first significant controversy' to the 'last significant controversy' in studied public policies.

The temporal dimension from the "first significant controversy to the 'last significant controversy' in case of the Right to Free and Compulsory Education Act, 2012 is the smallest but roots of its ideational construct are the farthest as compared to the other two legislation. In contrast, the temporal dimension of the Transplantation of Human Organs and Tissues Act, 2009 is the longest but its ideational constructs are the youngest and originated when the practice of organ transplantation successfully started in late 70s in Pakistan. Similarly, the temporal dimension of the Protection Against Harassment of Women at the Workplace Act, 
2010 falls in the middle of the other two legislations, as does origin of its ideational constructs and the temporal dimension. This implies that policy issues whose ideational constructs are well entrenched are justifiable for proposed solutions in lesser time than those whose ideational constructs have not yet taken firm roots.

5. The participation of 'providers' in either construction of ideational constructs or in shaping desires, preferences and motivations of other actors towards policy goals in studied public policies was almost negligible.

In all three legislative cases studied for this research, both the problematisation of the policy and its prescription originated and defined outside the legislature. In case of the Free and Compulsory Education Act, 2012, UNESCO had provided the technical assistance in drafting the legislation and presented as a private member bill in the Senate. The legislative package on the Protection Against Harassment of Women at the Workplace Act, 2010, was drafted by AASHA. Similarly, SIUT was closely involved in drafting the Transplantation of Human Organs and Tissues Act, 2009 with the first draft already prepared by Professor Dr. Adibul Hassan Rizvi. Also, in all three cases, the drafting of the legislation took references from similar legislative work, especially from India and other countries of the region. Importantly, normative roots of ideational constructs of all three legislative pieces originated from outside Pakistan.

6. There is a greater activity among detractors and actual outcomes tend to be compromised more from original policy goals in legislative cases that have weaker ideational roots. 
In the three legislative cases studied for this research, the stronger the ideational roots the lesser the contestation is and more close the law is from the original policy goals. The legislation on the Right to Free and Compulsory Education Act, 2012 met with the least resistance and the proposed bill was passed in its entirety. The idea that education is a right, which should be available to all children free of cost and compulsory, was generally agreed. In contrast, the legislation on the Transplantation of Human Organs and Tissues Act, 2009 met with a stiff resistance from anti-bill lobby. This not only prolonged the legislative process but also resulted in creating certain loopholes vulnerable for exploitation by the antibill lobby. In the case of the Protection Against Harassment of Women at the Workplace Act, 2010 , the contestation was managed by omission of certain words and inclusion of men also as a likely victim of harassment at the workplace. However, unlike the bill on transplantation, this legislation was not challenged in the Federal Shariat Court, though there was opposition from the religious political parties.

\section{The inclusiveness of different actors as will as the element of instrumentality} increases in the construction of ideational constructs as well as in shaping desires, preferences and motivations of other actors involved in the policy process in public policies that transpire from within than those that are transferred from outside.

In case of the Free and Compulsory Education Act, 2012, both the instrument, the piece of legislation, and the idea originated from outside the locale of actors engaged in this legislation. Not only this legislation was least discussed, its implications were not fully considered. As a result, the legislation still remains a law on papers without any implementation. In contrast, while the bill on Transplantation of Human Organs and Tissues aided from similar legislative initiatives in other countries of the region, its ideation process 
had primarily originated from within and engaged a range of actors from both the opposing and supporting sides. Similarly, the ideation process of the Protection Against Harassment of Women at the Workplace Act, 2012 originated from within and had engaged a range of actors from both sides of the spectrum. This also aided heavily on the women's rights movement in general and women's right to work in particular. In terms of the instrument, all the three cases studied for this research referred to similar legislations elsewhere in the region and in developed countries to draft the law.

8. As the inclusiveness of public, represented through interest groups, increases in shaping the policy agenda the policy debate is more at the foreground policy formulation. Similarly, with the increase in contestation over decision on policy formulation the dynamics move away from instrumentality to normative to material considerations.

In two of the studied legislations, namely the Protection Against Harassment of Women at the Workplace Act and the Transplantation of Human Organs and Tissues Act, public participation was highly visible in shaping of the public policy agenda. Both the proposals originated outside the immediate policy circles amongst concerned civil society organizations that later roped in other policy stakeholders as well as the legislature. Similarly, the research also shows that the contestation over the precise formulation of policy agenda steered it away from its instrumental dimension to normative appeal to material considerations. In case of the legislation against harassment of women at the workplace, the original policy proposal had to make certain concessions in view of the opposition from the religio-political parties. However, the resolution to the contestation between pro and anti-bill lobbies in case of the legislation on transplantation of human organs and tissues came with the intervention of the 
Supreme Court. With the expiration of the ordinance looming and in response to the instructions of the Supreme Court, the eventual legislation passed by the parliament was considerably a toned-down version of the original proposal with loopholes providing opportunity to commercial organ traders of exploitation. In the case of legislation on free and compulsory education, the policy process lacked both public participation and contestation in development and formulation of public policy agenda and was the result of ideas in the background of the policy formulation. Importantly, the element of contestation appears to falter in a closed political system.

\section{6: CONCLUDING WORDS}

One of the main purposes of this research was to advance the scholarship in policy studies with an interest in ideas and discourse for overcoming theoretical shortcomings. More specifically this research looked into as to what constitutes public policy process and how its outcomes are arrived, changed, stay stable or vary from sector to sector or from one region to another. For this purpose, the research made a basic claim that ideational institutionalism has the capacity to inform an endogenous account of complex institutional evolution, continuation, adaptation, and innovation. In the three legislative cases studied for this research, not only ideational process was able to inform how institutions, i.e. right to education, right to work or right to be free from any form exploitation, had evolved and continued over time and how in the context of Pakistan they were adapted and innovated, if at all. Unlike other three established schools in new institutionalism, the research confirms that actors involved in the policy process were oriented subjectively, through the ideation process to which they were exposed to and later expand it further, rather their desires, preferences and motivations being contextually given facts. The findings of the research 
further confirm that actors in the policy process are strategic and they rely on multiple criteria for favouring certain strategies over others. The criteria, as per the proposed ideational framework, can be categorised into three levels, namely material, normative and cognitive. Lastly, the research shows that ideas at the normative level have mostly been used in the foreground of the policy formulation for justification of proposed policy prescriptions. Also, in the three cases studied, ideas at the cognitive level have been used in the foreground of policy formulation and were essentially policy prescriptions from subject experts outside the policymaking helm to help policymakers in taking specific course of policy actions. The material dimension, interestingly, appeared more forcefully at the moment of 'last significant controversy,' essentially meaning when a particular pieces of legislation has to be passed and, as expected, is in the background of the policy formulation in form of self-interested ideas. Another basic contention laid out in theorising this research was that in contrast to the three established new institutionalisms, agents in ideational understanding are sentient who not just operate or adapt to existing institutions but can also create and maintain new institutions through their ideational abilities. While this goes beyond the scope of the existing research, it is contended that if an ideational institution is such where, for instance, free and compulsory education is seen as a right of every child, it could only be changed if a new set of ideational constructs are created not only refuting this existing premise but also establishing new ones, i.e. education is essentially a service that need to be procured like any other service available in the market. 
Table 8.5:

List of Interviews conducted for the Protection Against Harassment of Women at the Workplace Act, 2010

\begin{tabular}{|c|c|c|c|}
\hline Serial & Name & Organisation/Address & Role \\
\hline 1 & $\begin{array}{l}\text { Maliha } \\
\text { Husein }\end{array}$ & $\begin{array}{l}\text { Director } \\
\text { Mehergarh } \\
\text { House 33A, Street 16, F-7/2, } \\
\text { Islamabad } \\
\text { Tel: +92(0) } 512609741 \\
\text { maliha@mehergarh.org }\end{array}$ & $\begin{array}{l}\text { Founding Member of "Alliance } \\
\text { Against Sexual Harassment" and also } \\
\text { the head of Mehergarh, which became } \\
\text { secretariat for AASHA; she is also } \\
\text { sister of Dr. Fauzia Saeed. }\end{array}$ \\
\hline 2 & $\begin{array}{l}\text { Mohammad } \\
\text { Waseem }\end{array}$ & $\begin{array}{l}\text { Director } \\
\text { Interactive Resource Center } \\
102 \text { B, Nawab Town, Raiwind } \\
\text { Road, Lahore 53700, } \\
\text { Tel: +92 } 4235313038 / 9 \\
\text { Cell: +92 } 3008483519, \\
\text { Email: } \\
\text { waseemmohammad@gmail.com }\end{array}$ & $\begin{array}{l}\text { He is Founding Member of "Alliance } \\
\text { Against Sexual Harassment" and took } \\
\text { responsibility of mobilising support } \\
\text { and engaging media through running } \\
\text { campaigns. }\end{array}$ \\
\hline 3 & $\begin{array}{l}\text { Dr. Fauzia } \\
\text { Saeed }\end{array}$ & $\begin{array}{l}\text { Executive Director } \\
\text { Mehergarh } \\
\text { House 33A, Street 16, F-7/2, } \\
\text { Islamabad } \\
\text { Tel:+92(0) } 512609741 \\
\text { maliha@mehergarh.org }\end{array}$ & $\begin{array}{l}\text { She first took the initiative after she } \\
\text { herself experienced sexual harassment } \\
\text { in UNDP, she brought together } \\
\text { likeminded civil society organisations } \\
\text { to form "Alliance Against Sexual } \\
\text { Harassment" in 2001, and she also } \\
\text { authored the legislation. }\end{array}$ \\
\hline 4 & $\begin{array}{l}\text { Ibn Abdur } \\
\text { Rehman }\end{array}$ & $\begin{array}{l}\text { Chairperson } \\
\text { Human Rights Commission of } \\
\text { Pakistan } \\
\text { Aiwan-I-Jamhoor, 107-Tipu Block } \\
\text { New Garden Town, Lahore. } \\
\text { Tell: +92 } 4235838341 \\
\text { Cell: +92(0) } 3008414955 \\
\text { Email: hrcp@hrcp-web.org }\end{array}$ & $\begin{array}{l}\text { He was also the member of AASHA, } \\
\text { he leads Human Rights Commission } \\
\text { of Pakistan, an independent human } \\
\text { rights monitoring group, and played an } \\
\text { instrumental role in rallying concerned } \\
\text { political circles. }\end{array}$ \\
\hline
\end{tabular}




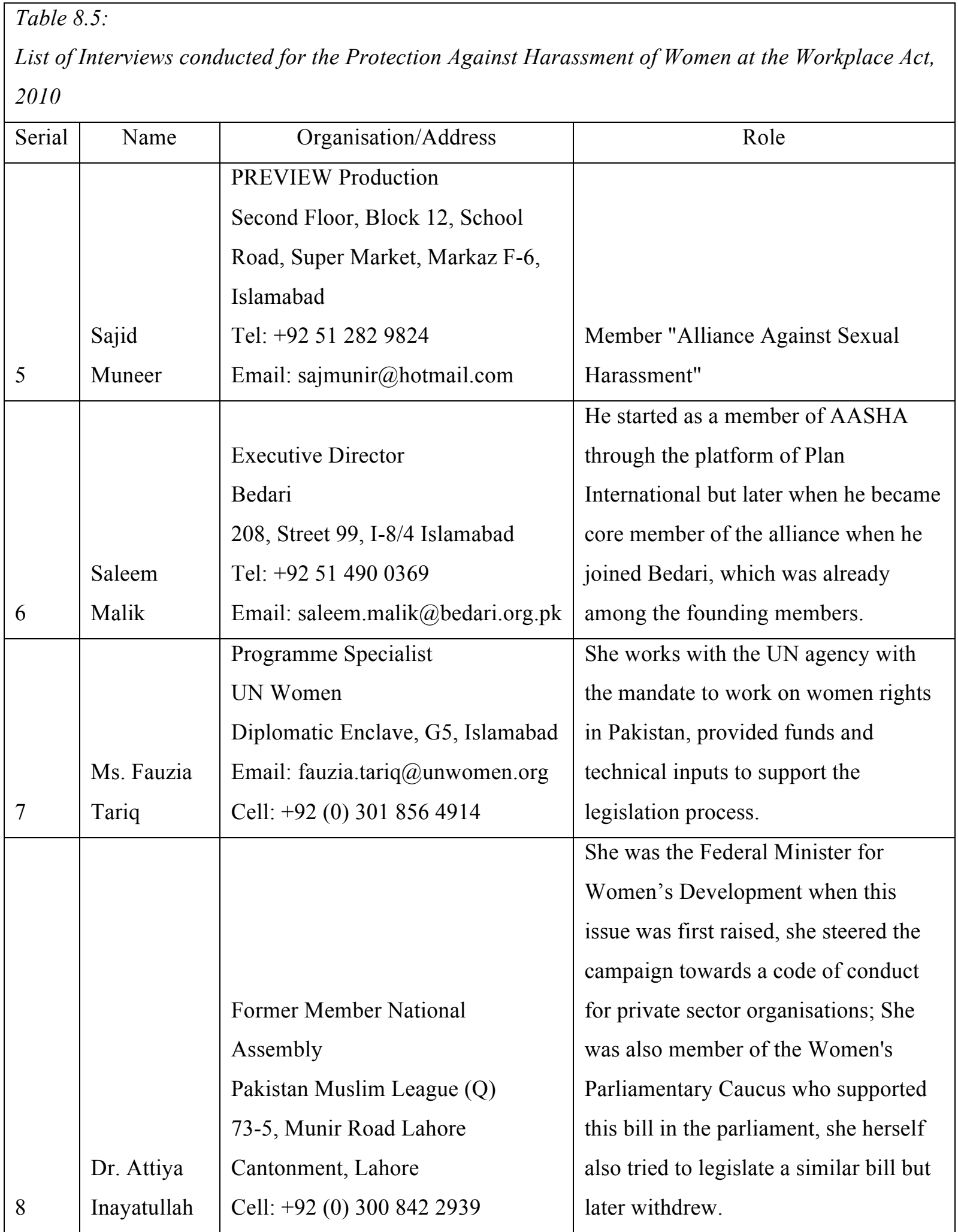




\section{Table 8.5:}

List of Interviews conducted for the Protection Against Harassment of Women at the Workplace Act, 2010

\begin{tabular}{|c|c|c|c|}
\hline Serial & Name & Organisation/Address & Role \\
\hline 9 & $\begin{array}{l}\text { Ms. Sherry } \\
\text { Rehman }\end{array}$ & $\begin{array}{l}\text { Former Minister for Information } \\
\text { and Broadcasting } \\
\text { Pakistan's Peoples Party } \\
\text { Executive President } \\
\text { Jinnah Institute } \\
1 \text { B, Nazimuddin Road, F-7/1, } \\
\text { Islamabad } \\
\text { Email: info@jinnah-institute.org } \\
\text { Tel: +92(0) } 512814161 / 63\end{array}$ & $\begin{array}{l}\text { She was the concerned Minister at the } \\
\text { time, and had additional portfolios of } \\
\text { Health, Women Development and } \\
\text { Culture as Federal Minister, she took } \\
\text { the bill as a private member but the } \\
\text { government of the time decided to } \\
\text { present it as a government bill. }\end{array}$ \\
\hline 10 & $\begin{array}{l}\text { Ms. Bushra } \\
\text { Gohar }\end{array}$ & $\begin{array}{l}\text { Member National Assembly } \\
\text { Awami National Party } \\
3 \text { Chinar Lane, University Town, } \\
\text { Peshawar } \\
\text { Cell: +92 (0) } 3008580473 \\
\text { Email: bushra.gohar@hotmail.com }\end{array}$ & $\begin{array}{l}\text { She was Chair of the National } \\
\text { Assembly's Standing Committee on } \\
\text { Women's Development to which this } \\
\text { bill was brought for endorsement; and } \\
\text { was also Member of the National } \\
\text { Commission on the Status of Women, } \\
\text { her party was in coalition with the } \\
\text { ruling Pakistan Peoples Party, and she } \\
\text { supported the bill throughout the } \\
\text { legislative process. }\end{array}$ \\
\hline
\end{tabular}




\section{Table 8.6:}

List of Interviews conducted for the Transplantation of Human Organs and Tissues Act, 2009

\begin{tabular}{|c|c|c|c|}
\hline Serial & Name & Organisation/Address & Role \\
\hline 1 & $\begin{array}{l}\text { Dr. Farhat } \\
\text { Moazam }\end{array}$ & $\begin{array}{l}\text { Professor and Chairperson } \\
\text { Centre of Biomedical Ethics and } \\
\text { Culture, Sindh Institute of Urology } \\
\text { and Transplantation } \\
\text { Karachi, Pakistan } \\
\text { 5th Floor, Dewan Farooq Medical } \\
\text { Complex } \\
\text { Karachi } \\
\text { Tel: +92 } 2132726338 \\
\text { Email: famoz@mindspring.com }\end{array}$ & $\begin{array}{l}\text { Dr. Farhat Moazam is the founding } \\
\text { Chairperson of Centre of Biomedical } \\
\text { Ethics and Culture at SIUT. Her } \\
\text { doctoral dissertation, "Bioethics and } \\
\text { Organ Transplantation in a Muslim } \\
\text { Society: A Study in Culture, } \\
\text { Ethnography and Religion," was } \\
\text { published by the Indiana University } \\
\text { Press, USA in September } 2006 \text {. She } \\
\text { was one of the rallying forces behind } \\
\text { the legislation form the SIUT platform } \\
\text { and worked directly with Professor } \\
\text { Adibul Hassan Rizvi. }\end{array}$ \\
\hline 2 & $\begin{array}{l}\text { Dr. Ghulam } \\
\text { Nabi Kazi }\end{array}$ & $\begin{array}{l}\text { National Professional Officer for } \\
\text { Program Development } \\
\text { World Health Organization } \\
\text { Near NIH, Park Road, Chak } \\
\text { Shahzad, Islamabad - Pakistan } \\
\text { Cell: +92 } 3005002895 \\
\text { Email: kazig@pak.emro.who.int }\end{array}$ & $\begin{array}{l}\text { UN agency mandated to work on } \\
\text { health issues in Pakistan, Dr. Kazi was } \\
\text { the focal person at the World Health } \\
\text { Organization providing technical and } \\
\text { financial support, as well carrying out } \\
\text { mobilisation and advocacy related } \\
\text { activities to support the legislation. }\end{array}$ \\
\hline 3 & $\begin{array}{l}\text { Dr Saeed } \\
\text { Akhtar }\end{array}$ & $\begin{array}{l}\text { Director } \\
\text { Urology and Transplantation } \\
\text { Department } \\
\text { Shifa International Hospital, } \\
\text { Islamabad } \\
\text { Cell: +923204504469 } \\
\text { Email: sakhtar100@hotmail.com }\end{array}$ & $\begin{array}{l}\text { He is the President of Transplantation } \\
\text { Society of Pakistan, and one of the key } \\
\text { actors among the community of } \\
\text { surgeons who pressed for legislation on } \\
\text { transplantation of human organs; he } \\
\text { regularly appeared on media promoting } \\
\text { the need for such legislation. }\end{array}$ \\
\hline
\end{tabular}




\section{Table 8.6:}

List of Interviews conducted for the Transplantation of Human Organs and Tissues Act, 2009

\begin{tabular}{|c|c|c|c|}
\hline Serial & Name & Organisation/Address & Role \\
\hline 4 & $\begin{array}{l}\text { Dr. Shahzad } \\
\text { Waseem }\end{array}$ & $\begin{array}{l}\text { Former Minister of State for } \\
\text { Interior } \\
\text { Former Senator of Pakistan } \\
\text { Advisor to The Chairman, Pakistan } \\
\text { Tehreek-e-Insaf } \\
\text { on Foreign Political Parties' } \\
\text { Relations } \\
\text { 6-C, Faiz Arcade, F-7 Markaz, } \\
\text { Islamabad } \\
\text { Cell: +923008506722 } \\
\text { Email: shahzad@dswpti.pk }\end{array}$ & $\begin{array}{l}\text { Due to his background knowledge and } \\
\text { interest in the subject, he tabled the } \\
\text { private-member bill on the same } \\
\text { subject in } 2003 \text {, which could not } \\
\text { succeed. He continued supporting the } \\
\text { legislation. }\end{array}$ \\
\hline 5 & $\begin{array}{l}\text { Dr. Ejaz } \\
\text { Rahim }\end{array}$ & $\begin{array}{l}\text { Former Federal Secretary Health } \\
\text { Chief of Party } \\
\text { Assessment and Strengthening } \\
\text { Programme } \\
\text { 70, Street 25, Sector F-10/1, } \\
\text { Islamabad } \\
\text { Cell: +92 } 03009888377\end{array}$ & $\begin{array}{l}\text { He was the Federal Secretary for } \\
\text { Health from year } 2000 \text { to } 2004 \text { and } \\
\text { currently leads and USAID funded } \\
\text { project. It was during his tenure when } \\
\text { the debate started intensifying on the } \\
\text { need for regulating the practice of } \\
\text { organ transplantation in Pakistan. }\end{array}$ \\
\hline 6 & $\begin{array}{l}\text { Professor } \\
\text { Major } \\
\text { Gen(R) Dr. } \\
\text { Abdul } \\
\text { Qadir } \\
\text { Usmani }\end{array}$ & $\begin{array}{l}\text { Former Administrator, HOTA } \\
\text { Head of Department \& Professor, } \\
\text { Yusra Medical \& Dental College } \\
\text { Near Kahuta Morr, GT Road, P.O. } \\
\text { Humak, Islamabad } \\
\text { Tel: +92 } 514492811 / 5\end{array}$ & $\begin{array}{l}\text { He was the first Head of the Human } \\
\text { Organ Transplantation Authority } \\
\text { tasked with ensuring the legislation is } \\
\text { implemented and the institutions } \\
\text { mandated for transplantation of human } \\
\text { organs are regulated. }\end{array}$ \\
\hline 7 & $\begin{array}{l}\text { Dr. Nadeem } \\
\text { Ehsan }\end{array}$ & $\begin{array}{l}\text { Former Member National } \\
\text { Assembly } \\
\text { Former Minister of State for } \\
\text { Overseas Pakistanis } \\
\text { Mutahida Qaumi Movement } \\
\text { A-378, Block D, North Nazimabad, } \\
\text { Karachi } \\
\text { Cell: } 0344-2664866\end{array}$ & $\begin{array}{l}\text { Chairman Standing Committee for } \\
\text { Health that reviewed the bill in } 2009 \text { of } \\
\text { human organ transplantation and } \\
\text { unanimously passed the bill without } \\
\text { any amendment. He was given the } \\
\text { credit for introducing the bill in the } \\
\text { Parliament and ensuring that it sails } \\
\text { through. }\end{array}$ \\
\hline
\end{tabular}




\section{Table 8.6:}

List of Interviews conducted for the Transplantation of Human Organs and Tissues Act, 2009

\begin{tabular}{|c|c|c|c|}
\hline Serial & Name & Organisation/Address & Role \\
\hline 8 & $\begin{array}{l}\text { Mr. Syed } \\
\text { Anwar } \\
\text { Mahmood }\end{array}$ & $\begin{array}{l}\text { Former Federal Secretary Health } \\
\text { Cell: +92 } 3008553033 \\
\text { Email: } \\
\text { sanwermahmood@hotmail.com }\end{array}$ & $\begin{array}{l}\text { He succeeded Dr. Ijaz Rahim as the } \\
\text { Federal Secretary for Health and took } \\
\text { over the responsibility of overseeing } \\
\text { deliberation held on legislating the } \\
\text { organ transplantation. He remained the } \\
\text { Federal Secretary from } 2005 \text { till } 2007 \\
\text { until he was appointed as the Federal } \\
\text { Secretary for Information and } \\
\text { Broadcasting. }\end{array}$ \\
\hline 9 & $\begin{array}{l}\text { Dr. Shuaib } \\
\text { Khan }\end{array}$ & $\begin{array}{l}\text { Former Medical Superintendent } \\
\text { Rawalpindi Institute of Cardiology } \\
\text { Cell: +92 } 3005551233 \\
\text { Email: shuaibkhan321@yahoo.com }\end{array}$ & $\begin{array}{l}\text { He was the first Medical } \\
\text { Superintendent of the Rawalpindi } \\
\text { Institute of Cardiology, which was } \\
\text { inaugurated in } 2012 . \text { He has been a } \\
\text { health administrator, and worked as } \\
\text { District Health Officer for the } \\
\text { Rawalpindi district, which was the } \\
\text { main hub where commercial organ } \\
\text { transplantation was taking place. }\end{array}$ \\
\hline
\end{tabular}




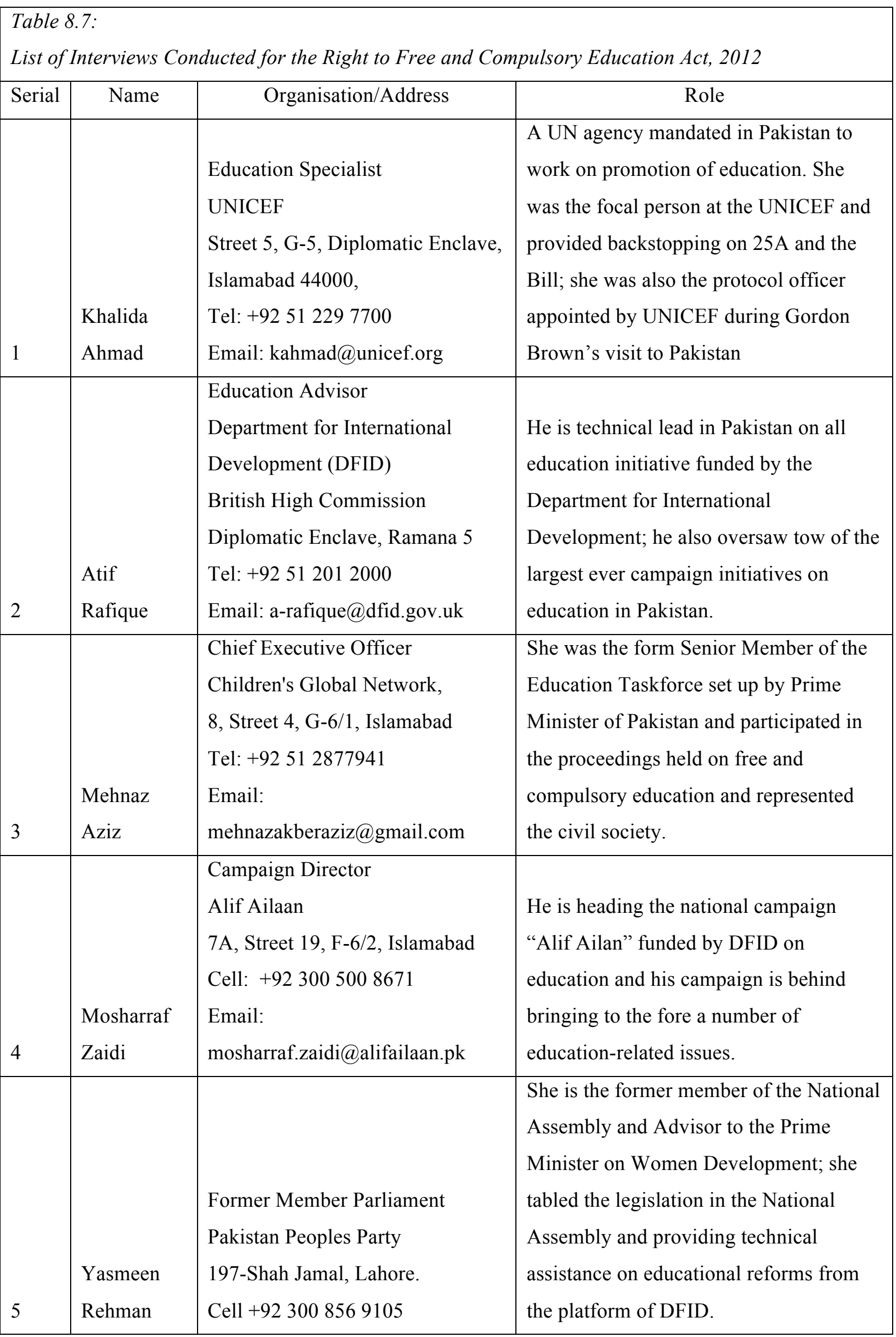




\begin{tabular}{|c|c|c|c|}
\hline Serial & Name & Organisation/Address & Role \\
\hline 6 & $\begin{array}{l}\text { Arshad } \\
\text { Saeed Khan }\end{array}$ & $\begin{array}{l}\text { Senior National Specialist } \\
\text { UNESCO } \\
\text { Serena Business Complex, 7th } \\
\text { Floor, Sector G-5, Islamabad } \\
\text { Tel: +92(0) } 51111710745 \\
\text { Email: askhan51@yahoo.com }\end{array}$ & $\begin{array}{l}\text { He was the focal person at the UNESCO } \\
\text { office in Pakistan, the agency mandated } \\
\text { by United Nations to work on promotion } \\
\text { of education in Pakistan. He facilitated in } \\
\text { drafting the legislation and also } \\
\text { coordinated the legislative process. }\end{array}$ \\
\hline 7 & $\begin{array}{l}\text { Mr. Khalid } \\
\text { Hanif }\end{array}$ & $\begin{array}{l}\text { Additional Secretary } \\
\text { Ministry of Education and } \\
\text { Trainings } \\
\text { Room \# 113, first floor, Block C, } \\
\text { Pak. Secretariat, Islamabad } \\
\text { Tel: +92 (0) } 519204565\end{array}$ & $\begin{array}{l}\text { He represents the Federal Ministry, } \\
\text { responsible for Islamabad Capital } \\
\text { Territory in which the legislation is } \\
\text { implementable; he is a Senior Bureaucrat } \\
\text { who participated and represented in the } \\
\text { proceedings held towards drafting the } \\
\text { legislation. }\end{array}$ \\
\hline 8 & $\begin{array}{l}\text { Mr. Ahmed } \\
\text { Ali }\end{array}$ & $\begin{array}{l}\text { Research Fellow } \\
\text { Institute of Social and Policy } \\
\text { Studies (I-SAPS) } \\
\text { House No. 13, Street No. 1, G-6/3, } \\
\text { Islamabad } \\
\text { Tel: +92 (0) } 51111739739 \\
\text { Email: info@i-saps.org }\end{array}$ & $\begin{array}{l}\text { He heads an independent organisation } \\
\text { that facilitated the bill through technical } \\
\text { input and research, especially through } \\
\text { provision cost and benefit analysis, } \\
\text { budgetary and resource planning and } \\
\text { legal implications of the legislation. }\end{array}$ \\
\hline 9 & $\begin{array}{l}\text { Dr. Faisal } \\
\text { Bari }\end{array}$ & $\begin{array}{l}\text { Senior Adviser for Pakistan } \\
\text { Open Society Foundation Pakistan } \\
\text { Email: fbari@sorosny.org }\end{array}$ & $\begin{array}{l}\text { He represents Open Society Foundation } \\
\text { that funded various small and large } \\
\text { initiatives to help carve a path for } \\
\text { legislation on free education. }\end{array}$ \\
\hline 10 & S. M. Zafar & $\begin{array}{l}\text { Senator } \\
\text { Pakistan Muslim League (Q) } \\
\text { 401-Siddique Trade Centre, 72, } \\
\text { Mian Boulevard, Gulberg, Lahore } \\
\text { Cell: +92 } 3008455377 \\
\text { Email: s.m.zafar@senate.gov.pk }\end{array}$ & $\begin{array}{l}\text { A senior politician, known for his } \\
\text { bipartisanism and highly respected. He } \\
\text { tabled the legislation in the Senate and } \\
\text { was also member Review Committee that } \\
\text { looked into the drafting of the Eighteenth } \\
\text { Amendment to the } 1973 \text { Constitutions, } \\
\text { and it was on his recommendation the } \\
\text { Article } 25 \mathrm{~A} \text { was inserted which became } \\
\text { the basis for the legislation. }\end{array}$ \\
\hline
\end{tabular}




\begin{tabular}{|c|c|c|c|}
\hline \multicolumn{4}{|c|}{ Table 8.7: } \\
\hline Serial & Name & Organisation/Address & Role \\
\hline 11 & $\begin{array}{l}\text { Sheikh } \\
\text { Waqas } \\
\text { Akram }\end{array}$ & $\begin{array}{l}\text { Former Minister of Education } \\
\text { Pakistan Muslim League (N) } \\
\text { Pique, Office \#4, 4th Floor, } \\
\text { Evacuee Trust Complex, Sir Aga } \\
\text { Khan Road, F-5/1, Islamabad } \\
\text { Tel: +92 } 512873311 \\
\text { Email: pique@pique.pk }\end{array}$ & $\begin{array}{l}\text { He was the Federal Minister of Education } \\
\text { at the time when Article } 25 \mathrm{~A} \text { was } \\
\text { inserted and the legislation was passed on } \\
\text { free and compulsory education two years } \\
\text { later. }\end{array}$ \\
\hline 12 & $\begin{array}{l}\text { Mr. Qamar } \\
\text { Zaman } \\
\text { Chaudhary }\end{array}$ & $\begin{array}{l}\text { Former Secretary Education } \\
\text { National Accountability Bureau } \\
\text { Attaturk Avenue, G-5/2, } \\
\text { Islamabad } \\
\text { Tel:+92 } 51111622622 \\
\text { Email: chairman@nab.gov.pk }\end{array}$ & $\begin{array}{l}\text { He was the Federal Secretary for } \\
\text { Education, at the time of passing of the } \\
\text { Bill. He had also attended parliamentary } \\
\text { briefings on the Bill and provided } \\
\text { explanations sought by the members of } \\
\text { the parliament. At the time of the } \\
\text { research, he was heading the National } \\
\text { Accountability Bureau and declined to } \\
\text { give the interview. }\end{array}$ \\
\hline
\end{tabular}




\section{TOWARDS A NEW POLICY MAKING PARADIGM OF}

\section{IDEAS}

\section{1: INTRODUCTION}

he present research has contributed to a growing body of literature on the role of
ideas in public policy and institutional change. While much of the scholarship is
in nascent stage, the research has examined some of the basic claims of ideational institutionalism through post-empirical analysis of three social-sector legislations in Pakistan. This research is primarily descriptive and made an effort to depict the essential features of policymaking in countries of grey-zone, regardless of their political structure. The research has helped lay out essential features of ideational institutionalism by introducing and applying an ideational framework of public policy, which combines cognitive, normative and material dimensions behind a policy decision.

In this concluding chapter, the next section sets the agenda for future research in light of the implications of the findings and conclusions drawn upon them. Thereafter, a section is devoted on existing typologies of public policy that have been introduced in the last halfcentury to help conceptualise the study of public policy and more specifically to overcome the limitations in the case study method from positivist perspective. ${ }^{1}$ A section follows this to

\footnotetext{
${ }^{1}$ Steinberger, Peter J., "Typologies of Public Policy: Meaning Construction and the Policy Process," in Irving Louis Horowitz (ed.) Policy Studies Review Annual, Vol. 5 (California: Sage, 1981): 28
} 
briefly introduce readers to a new typology based on the origin of public policy and consisting of its two basic elements - the problem and its solution. Some concluding words are offered at the end.

\section{2: AGENDA FOR FUTURE RESEARCH}

The wider constructivist argument considers ideas to be the constructs of both the agents and the reality. Bell, however, distinguishes between postmodern constructivists who argue that ideas fully constitute agents and the context of action and modern constructivists who assume the external material world in which ideas mediate the relationship between agents and material reality. ${ }^{2}$ The findings from this research for all the three cases confirm the latter where ideational constructs have continuously interacted with the material reality. The findings also bring out a more active role of agency both in shaping and in return shaped by wider institutional and structural environment. As Bell writes, in ideational institutionalism, "Institutions are shaped by the agents, but institutions also confront agents," for their own constitution and thus act as both constraining and enabling constructs. ${ }^{3}$ The findings highlight the central role of ideas in the process of creation and change of institutions. It also underlines what Béland calls the relationship between politics of ideas and politics of interests that posits interest as construction of ideational processes. ${ }^{4}$

One of the basic claims of this research was that it is not just a rational pursuit of actors for maximising their self-interest, or dictation of their actions through symbolic systems,

\footnotetext{
${ }^{2}$ Bell, S., "The Power of Ideas: The Ideational Shaping of the Structural Power of Business," International Studies Quarterly, Vol. 56 (2012): 666

${ }^{3}$ Ibid, 667

${ }^{4}$ Béland, D., "Ideas and Institutional Change in Social Security: Conversion, Layering, and Policy Drift," Social Science Quarterly, Vol. 88, No. 1 (2007): 34
} 
cognitive scripts or moral templates, or even their dependency on enduring legacies but essentially an interplay of myriad of ideas that have cognitive, normative and material characteristics. The institutional change, of any degree of order, is only possible if there is a change in expectations and values assigned to the existing set of ideas. As Legro writes, "Ideational transformation depends on the existence of an opposing idea with social support, which implies the necessity of individuals creatively opposing the dominant orthodoxy until circumstances are conducive." ${ }^{, 5}$ While the research has shed light on the role of ideas in explaining politics of public policy, more research is needed to explain what factors lead to enduring ideas sometimes collapse suddenly and consolidate into a new set of dominant ideas or altered incrementally over a longer period of time. ${ }^{6}$ More precisely, what are those conditions under which existing institutions give in to new ideational constructs either through critical junctures and exogenous shocks or through incremental change, whether it is through layering, conversion or policy drift on to established institutional framework or completely endogenously through sentient agents. ${ }^{7}$

Osman concludes, while studying implications of public policy theories in developing countries, "most of the policy making theories [are] derived from the studies of industrially developed societies, which in most cases, are found insufficient to explain the policies of developing countries due to the contextual variations." ${ }^{8}$ The strength of ideational institutionalism is its adaptability to any context, i.e. political, social or economic. As Schmidt writes, "The ideas it elucidates may be cognitive or normative, come at different levels of generality, including policy, programs, and philosophy, and in different forms, such

\footnotetext{
${ }^{5}$ Ibid, 429

${ }^{6}$ Legro, Jeffrey W., “The Transformation of Policy Ideas," American Journal of Political Science, Vol. 44, No. 3 (2000): 419

${ }^{7}$ Béland, D., 2007: 22

${ }^{8}$ Osman, Ferdous A., "Public Policy Making: Theories and Their Implication in Developing Countries," Asian Affairs, Vol. 24, No. 3 (2000): 37
} 
narratives, frames, frames of references, discursive fields of ideas, argumentative practices, story telling, collective memories and more..." He continues that they "may involved polity actors in epistemic communities and advocacy coalitions ...[while] the discursive interactions may come not only from the top down through the influence of the ideas of supranational or national actors but also from the bottom up through the ideas and discourse of local, national and/or international 'civil society ' and social movement activists. ${ }^{10}$ Analytic generalisation and the case study approach, however, requires applying the theoretical constructs arrived through this research as a template to other political and policy settings. ${ }^{11}$

This research highlights the distributed nature of discourses across institution and their struggle to gain recognition and power in policymaking arena. Legislative cases studied for this research have revealed how the main actors involved in the process have employed power and relations for furthering their desired policy outcomes. The research also highlights that it is only when ideas draw on and interact with available discourses, in view of the larger context, that they become independent and a force to reckon with. It is not possible to understand policy decisions simply as the consequence of interests. ${ }^{12}$ It is the substantive content of ideas and the interactive processes of discourse in an institutional context that respond to material realities and shape preferences of actors. ${ }^{13}$ Politics, however, is a struggle between discourses and the struggle between discourses is always a struggle between

\footnotetext{
${ }^{9}$ Schmidt, Vivian A., "Ideas and Discourse in Transformational Political Economic Change in Europe," in Grace Darlene Skogstad (ed.) Policy Paradigms, Transnationalism, and Domestic Politics (Toronto, University of Toronto Press, 2011): 35

${ }^{10}$ Schmidt, Vivian A., "Ideas and Discourse in Transformational Political Economic Change in Europe," in Grace Darlene Skogstad (ed.) Policy Paradigms, Transnationalism, and Domestic Politics (Toronto, University of Toronto Press, 2011): 35

${ }^{11}$ Yin, Robert K., Application of Case Study Research (London: SAGE Publication, 2012): 19

${ }^{12}$ John, P., Analyzing Public Policy, 2nd ed. (Abingdon: Routledge, 2012): 14

${ }^{13}$ Schmidt, Vivien A., "Speaking of Change: Why Discourse is Key to the Dynamics of Policy Transformation," Critical Policy Studies, Vol. 5, No. 2 (2011): 124
} 
different sets of ideas. ${ }^{14}$ An important element of discourse is, as Dahlberg defines, hegemonic formation of social relations that necessarily involve hierarchies of power and relations of inclusion and exclusion. ${ }^{15}$ It is precisely here, if ideas and discourse matters as this research signifies, the question arises how and when does discourse matter or as Schmidt asks, "when do they [discourse and ideas] exert a causal influences? And when don't they?"16 The proposed ideational framework of public policy could help in elucidating how one set of ideas become hegemonic over other competing sets of ideas.

One of the most intriguing fields of public policy analysis has been the effort to classify public policies. ${ }^{17}$ It dates back to Theodore Lowi' policy typology introduced in 1964 which since then has produced a variety of concepts attempting to categorize policies so that relationship between substance and process can be more clearly understood." ${ }^{\prime 18}$ It is essentially a departure from Lasswellien approach to public policy, and an attempt to have predictive models of public policy. However, this approach has proven to be frustrating, as Steinberger explains, because of the difficulty of classifying public policy cases as being of this type or that. ${ }^{19}$ Steinberger writes, "We should regard ambiguity not as a defect in understanding but, rather, as a salient and ineluctable characteristic of public policy. ${ }^{, 20} \mathrm{He}$ proposes a phenomenological approach to policy analysis and essentially asks to embrace

\footnotetext{
${ }^{14}$ Fenton, N., "Multiplicity, Autonomy, New Media and the Networked Politics of New Social Movement," in Lincoln Dahlberg and Sean Phelan (eds.) Discourse Theory and Critical Media Politics (New York: Palgrave MacMillan, 2011): 192

${ }^{15}$ Dahlberg, L., "Discourse Theory as Critical Media Politics? Five Questions," in Lincoln Dahlberg and Sean Phelan (eds.) Discourse Theory and Critical Media Politics (New York: Palgrave MacMillan, 2011): 41

${ }^{16}$ Schmidt, Vivien A., "Reconciling Ideas and Institutions through Discursive Institutionalism," in Daniel Béland and Robert Henry Cox (eds.) Ideas and Politics in Social Science Research (Oxford: Oxford University Press, 2011): 61

${ }^{17}$ Steinberger, Peter J., 1981: 27

${ }^{18}$ Ibid

${ }^{19}$ Ibid, 28

${ }^{20}$ Steinberger, Peter J., 1981: 31
} 
ambiguity in policy process as fundamental and unavoidable. ${ }^{21} \mathrm{He}$ argues, "The participants inevitably engage in typification in meaning construction, and the typological tradition is useful in specifying, categorizing and conceptualizing those various typifications." ${ }^{22} \mathrm{He}$ asserts, "the best of the typologies are plausible and useful in that they describe typifications that are generally and commonly employed by participants in the political process to define public policies...they are insightful in elucidating and in specifying socially constructing meaning. ${ }^{, 23}$ Based on the findings of this research, a typology is proposed in Section 8.4 that aspires to embrace ambiguity in policy process and typifies policies as per their socially constructed meanings. A brief review of existing typologies is provided first in the following section.

\section{3: TYPOLOGIES OF PUBLIC POLICY}

There exists several types of public policies, as discussed by Stewart et al, such as liberal or conservative, substantive or procedural, material or symbolic and collective versus private. ${ }^{24}$ Such categorisation is based on the contents or functionality of public policies. Other forms of more traditional categorisations are usually by issue area such as labour, welfare or foreign affairs, by institution such as judicial, executive or legislative and by time such as post-World War II or late nineteenth century. ${ }^{25}$ At minimum, such categorisation helps organising discussion and brings some structure to study public policy given their complexity and large numbers. While helpful, categorisations are not useful in generalisation, because they do not

\footnotetext{
${ }^{21}$ Ibid

${ }^{22}$ Ibid

${ }^{23}$ Ibid

${ }^{24}$ Stewart, J., Hedge, David M., and Lester, James P., Public Policy: An Evolutionary Approach. 3rd ed. (Boston, MA: Thomson Higher Education, 2008): 7 - 8

${ }^{25}$ Anderson, J. E., Public Policymaking: An Introduction (Boston: Houghton Mifflin Company, 2003)
} 
reflect the basic characteristics and content of policies. ${ }^{26}$ A typology, on the other hand, provides theoretical structure. Smith writes, "Typologies draw their theoretical strength from the idea that public policies can be systematically classified and that associated with each policy category are distinct and predictable patterns of political behaviour., ${ }^{27}$

One of the most durable analytical frameworks of classification as Smith would like to call it, is the policy typology introduced by Theodore Lowi. Lowi's typology is based on the argument that different types of policies result in different types of relationships among individuals and groups, and these relationships can be described and predicted on the basis of policy type. ${ }^{28}$ It consists of four categorisations, namely distributive, redistributive, regulatory and constituent policies. Distributive policies relate to distribution of resources while redistributive are transfer of resources from one group to another. Regulatory policies specify conditions and constraints for individual and collective behaviour and constituent policies are concerned with creating or modifying state's institutions. Lowi' basic argument was, explain Smith and Larimer, "if one could identify the type of policy under consideration - in other words, if one could classify a policy into a particular cell in his 2 x 2 table - one could predict the type of politics likely to follow." 29 Collier et al write, "If typologies are to meet the norms for standard categorical scale, the cells should be mutually exclusive and collectively exhaustive [and] for the purpose of classification, it is essential that these dual criteria be met." ${ }^{30}$ However, Lowi's typology failed to meet this basic analytical distinction,

\footnotetext{
${ }^{26}$ Ibid, 3

${ }^{27}$ Smith, Kevin B., "Typologies, Taxonomies, and the Benefits of Policy Classification," Policy Studies Journal, Vol. 30, No. 3 (2002): 379

${ }^{28}$ Ibid

${ }^{29}$ Smith, Kevin B. and Larimer, Christopher W., The Public Policy Theory Primer, 2nd ed. (Boulder, Westview Press, 2013): 36

${ }^{30}$ Collier, D., Laporte, J., and Seawright, J., "Typologies: Forming Concepts and Creating Categorical Variables," in Janet M. Box-Steffensmeier, Henry E. Brady, and David Collier (eds.), The Oxford Handbook of Political Methodology (Oxford: Oxford University Press, 2015)
} 
as Knill and Tosun argue, "the clarity of typology dissolves and conceptual ambiguities among the policy types can be identified."31

Of the influential typologies, the typology introduced by James Q. Wilson is also considered one. ${ }^{32}$ Through his typology, Wilson explores how distribution of costs and benefits from introduction of a policy draw politics. ${ }^{33}$ For instance, if costs and benefits of a policy are both diffused, the government may likely to encounter no or little opposition indicating a majoritarian policy. In contrast, if both costs and benefits of a policy are concentrated, the government is likely to be confronted by the rival interest group triggering interest group politics. In client policies costs are distributed to a large group while benefits are concentrated to some single, reasonably small interest, i.e. industry, profession or locality, while in entrepreneurial policies the reverse is the case. Since in client policies benefits are large to one group they have benefit in organising and pressing for the law while the costs are so vastly disbursed that those affected by policy have no incentive to organize to oppose the law. In entrepreneurial policy, those benefiting have little or no incentive to press for the law while those affected have high costs to bear and will organise to oppose the propose law. ${ }^{34}$ Echeverri-Gent argues that Wilson's typology has little to say about sources of power of different actors and it does not explain, "How discourse within policy communities shapes the interest and objectives of government agencies and social groups forming part of a policy

\footnotetext{
${ }^{31}$ Knill, C. and Tosun, J., Public Policy: A New Introduction (Hampshire: Palgrave MacMillan, 2012): 17

${ }^{32}$ Ibid, 16

${ }^{33}$ See: Wilson, James Q., Bureaucracy: What Government Agencies do and Why they do it (New

York: Basic Books, 1989)

${ }^{34}$ Ibid, $76-77$
} 
network." ${ }^{35}$ More fundamentally, both Lowi's typology and Wilson's improvement upon it are reflective of pluralistic societies and depend heavily on interest-group theories. ${ }^{36}$

In presenting the most influential analytical classifications of public policy, Knill and Tosun explain, "With the maturation of public policy analysis, typologies have increasingly emphasized a similarity in terms of analytical considerations." ${ }^{37}$ They discuss several classification schemas in terms of public policies and their implication for politics [such as the one introduced by Lowi and Wilson], by their governance principles and instruments [incentivise or taxation], or by dimension [output, outcome and impact], content or style [anticipatory, active or reactive or consensual or imposed] of policy. ${ }^{38}$ Regardless of different types of classifications and typologies, a common thread in all such endeavours is to study the contents or functionality of public policies. However, there is no classification or typology to date that could describe the relationship between how policies originate and how the policy process unfolds as a result of it.

\section{4: A TYPOLOGY BASED ON THE ORIGIN OF PUBLIC POLICY}

In policy-as-discourse, policies are not seen as governments responding to problems rather problems are created in the very policy proposals that are offered as response. ${ }^{39}$ In this perspective, policy process consists of two main components, the problems that are created

\footnotetext{
${ }^{35}$ Echeverri-Gent, J., The State and the Poor: Public Policy and Political Development in India and the United States (California: University of California Press, 1993):21

${ }^{36}$ Miller, Johnston K., and McTavish D., Making and Managing Public Policy (Abingdon: Routledge, 2014): 17

${ }^{37}$ Knill, C. and Tosun, J., Public Policy: A New Introduction (Hampshire: Palgrave MacMillan, 2012): 16

${ }^{38}$ Knill, C. and Tosun, J., Public Policy: A New Introduction (Hampshire: Palgrave MacMillan, 2012): 16

${ }^{39}$ Bacchi, C., "Policy as Discourse: What does it mean? Where does it get us?" Discourse: Studies in the Cultural Politics of Education, Vol. 21, No. 1 (2000): 45 - 57
} 
and its solutions offered. The research, though based on a limited number of case studies, elucidates a pattern of how a policy process unfolds depending on the origin of the public policies. Based on this, four policy schemas are proposed on 2 x 2 matrix. First classification is based on an indigenous policy setting as in both the policy issue and its policy proposals are homegrown. Such policies may be referred as those that 'transpire.' In contrast, public policies in which both the proposal and the issues are created by forces outside the country are referred to as 'transported.' In this research, the right to education and the ensuing legislation on free and compulsory education may be falling in this category. In cases where policy issues are local but their solutions have been sought from outside the country are referred as 'transferred.' This seems to be the case in both the legislations on human organ transplantation and protection against harassment of women discussed in the previous chapter. Lastly, a policy setting where policy issues originate outside the country but their solutions are sought locally may be called public policies that 'transcended' (see the typology matrix below.)

\begin{tabular}{|c|c|c|c|}
\hline \multicolumn{2}{|l|}{ Typology based on the Origin of } & \multicolumn{2}{|c|}{ Policy Proposal } \\
\cline { 3 - 4 } Public Policies & Foreign & Transported & Local \\
\hline \multirow{2}{*}{ Policy Issue } & Local & Transferred & Transpired \\
\cline { 2 - 4 } & & & \\
\hline
\end{tabular}

With the help of abovementioned schema, several policymaking dynamics can be traced. Inclusiveness of local actors involved and affected by a policy issue in forging its proposals will tend to be the higher in policies that transpire and gradually decline in transcended policies and those that are transferred to be the least in transported policies. In contrast, the involvement of external actors will be the most in policies that are transported and least in those that transpire. This will also be the case in terms of the time dimension with policies 
taking the least time from the 'first significant controversy' to the 'last significant controversy,' in transported policies and the most if policies are transpired. Similarly, policies that are transpired will have stronger instrumental dimension but weaker normative appeal, and gradually declining from transferred policies to transcended policies and finally to transported policies being instrumentally the weakest but stronger in their normative appeal.

Importantly, it is conjectured that regime type, i.e. democracy, hybrid, or autocracy, might also have implications for the proposed typology. In a closed political system, it is less likely for the policies to be transferred and even less likely to be transported. Conversely, policies where problems are transcended and solutions are sought locally as well as where policies are grappled locally are more likely to be the scenarios in politically closed societies. In politically open societies, the transference of policies is more like to be from places that have similar political dynamics. Interestingly, transportation of policies will also be less likely in politically open societies as is the case in politically closed. It can also be claimed that there will be more cases of policies to be transpiring in politically open societies. The policy arena in hybrid regimes is likely to be messier with more cases of policy transference and policies less likely to be transpiring. Further research is required to elucidate implications, if any, of a regime type, on the proposed typology and dynamics associated with policymaking.

The purpose of this typology is descriptive in order to depict the essential features of policymaking process. Rather than indulging into a scientific study of public policy and an attempt at developing a causal theory, such a schema is helpful in describing public policy process by simplifying the phenomenon and emphasising on the conceptual and theoretical insights. 


\section{5: CONCLUDING WORDS}

A major reason, writes Fischer, policy theory has neglected ideas is because of its general theoretical shortcomings. ${ }^{40}$ There is already a lack of unity to the study of public policy. ${ }^{41}$ John acknowledges, "Public policy is hard to research effectively as it is a composite of different processes that crosscut most branches of government and involve many decision makers." 42 Pal poses a question, "Will old tools be adequate [in policy analysis] when the edifice is being drastically renovated?"43 For him the answer is no. Pal believes that for policymaking and policy analysis to become relevant they need to recognise that the dynamics around old problems have changed to a large extent as well as entirely new problems have originated. Also, citizens are now demanding more direct participation in policymaking and how governments interact with the private sector and civil society has changed. ${ }^{44}$ Recent theoretical advancements and research on the role of ideas is encouraging and has helped advance the theoretical development in public policy. ${ }^{45}$ Theory, if defined broadly, is a set of analytical principles to help structuring our observations and explanation of the world. ${ }^{46}$ In other words, it is simplification of the complex real world. John believes, "the genie in the bottle is ideas." John argues that while he is sympathetic to the importance of ideas, it needs to theorize about the importance of interests [and] the challenge is to come up with a theory of public policy that accepts that individuals seek to follow their interests

\footnotetext{
${ }^{40}$ Fischer, F., Reframing Public Policy: Discursive Politics and Deliberative Practices (Oxford: Oxford University Press, 2003): 27

${ }^{41}$ John, P., Analyzing Public Policy, 2nd ed. (Abingdon: Routledge, 2012): 7

${ }^{42}$ Ibid

${ }^{43}$ Pal, L., Beyond Policy Analysis: Public Issue Management in Turbulent Times, 4th ed. (Toronto: Nelson, 2015): 35

${ }^{44}$ Ibid, $35-36$

${ }^{45}$ John, P., 2012: 9

${ }^{46}$ Cairney, P., "Standing on the Shoulders of Giants: How Do We Combine the Insights of Multiple Theories in Public Policy Studies?" Policy Studies Journal, Vol. 43, No. 1 (2013): 1
} 
but understands they may acquire ideas about how to do so. ${ }^{, 47}$ By considering interests as just another type of ideas, the proposed ideational framework of public policy is an effort to specify the relationship between ideas and interests. Positivist methodologies are inadequate to deal with the complexity and subjectivity of policymaking process. Their quest for a single objective reality is neglectful of politics, which is primarily an interpretive and value driven exercise. This research reiterates post-positivists agenda for future research to study "how policy ideas shape policymaker expectations and the patterns of politics that result, especially which types of political actors are empowered."48

\footnotetext{
${ }^{47}$ John, P., 2012: 14

${ }^{48}$ Cook, B., "Arenas of Power in Climate Change Policymaking," Policy Studies Journal, Vol. 38, No. 3 (2010): 483
} 



\section{ANNEXURES}

\section{STUDY TOOLS}

\begin{tabular}{|c|c|}
\hline \multicolumn{2}{|c|}{$\begin{array}{l}\text { Annexure 1.1: } \\
\text { Discussion Guidelines - Providers }\end{array}$} \\
\hline Contentions & Guidelines \\
\hline \multirow{2}{*}{$\begin{array}{l}\text { 1. Pre-interpretation / } \\
\text { interpretation }\end{array}$} & 1.1 Why you think this piece of legislation was required? \\
\hline & $\begin{array}{l}\text { 1.2 Do you think this issue existed for sometime, if yes then why this } \\
\text { legislation could have been passed into law during the tenure of the last } \\
\text { government, what factors were at play to make it successful? }\end{array}$ \\
\hline \multirow{5}{*}{$\begin{array}{l}\text { To identify the } \\
\text { problem how it is } \\
\text { represented in policy } \\
\text { and to ascertain the } \\
\text { conceptual premise or } \\
\text { logic that underpin the } \\
\text { same in its } \\
\text { representation. }\end{array}$} & 1.3 After passing of this legislation, what benefits you expect this to bring? \\
\hline & $\begin{array}{l}\text { 1.4 How did you first come to know of this issue from a legislative } \\
\text { perspective? }\end{array}$ \\
\hline & 1.5 Who had first introduced you to this issue requiring legislation? \\
\hline & $\begin{array}{l}\text { 1.6 What sources, organisational, individual, or literature, did you } \\
\text { personally explore to learn about this issue? }\end{array}$ \\
\hline & $\begin{array}{l}1.7 \text { Were you briefed on this issues; who/ which organisation held briefings } \\
\text { for you? }\end{array}$ \\
\hline \multirow{8}{*}{$\begin{array}{l}\text { 2. Identity } \\
\text { To assess how } \\
\text { different actors view } \\
\text { individuals and } \\
\text { organisations involved } \\
\text { and how their } \\
\text { identities are shaped in } \\
\text { the public policy } \\
\text { process. }\end{array}$} & $\begin{array}{l}2.1 \text { Which organisations or individuals you think were crucial for making } \\
\text { this legislation happen? }\end{array}$ \\
\hline & $\begin{array}{l}\text { a) How would you describe their role, i.e. positive, critical, constructive, } \\
\text { please explain? }\end{array}$ \\
\hline & $\begin{array}{l}2.2 \text { Were there any actors or organisation that might have impeded the } \\
\text { process? }\end{array}$ \\
\hline & a) Why they were against the proposed legislation? \\
\hline & b) What were the reasons because of which they were unsuccessful? \\
\hline & c) How would you personally describe your role in the legislation process? \\
\hline & $\begin{array}{l}2.2 \text { Were there any organisations or individuals who gained popularity, } \\
\text { importance or fame because of this legislation? }\end{array}$ \\
\hline & 2.3 Were there any organisations or individuals whose mandate was to \\
\hline
\end{tabular}




\begin{tabular}{|c|c|}
\hline \multicolumn{2}{|c|}{$\begin{array}{l}\text { Annexure 1.1: } \\
\text { Discussion Guidelines - Providers }\end{array}$} \\
\hline \multirow[t]{2}{*}{ Contentions } & Guidelines \\
\hline & advocate for this particular legislation? \\
\hline \multirow[t]{2}{*}{ 3. Knowledge } & 3.1 Who provided technical inputs towards framing this legislation? \\
\hline & $\begin{array}{l}3.2 \text { Were practical dimensions of implementation of this legislation were } \\
\text { considered? }\end{array}$ \\
\hline \multirow{5}{*}{$\begin{array}{l}\text { To highlight the } \\
\text { instrumental } \\
\text { dimensions and the } \\
\text { extent to which it is } \\
\text { used in framing public } \\
\text { policy solutions. }\end{array}$} & $\begin{array}{l}\text { 3.3 Were there any other options or provisions considered for this } \\
\text { legislation, which were dropped due to impracticality? }\end{array}$ \\
\hline & $\begin{array}{l}\text { 3.4 Were experts involved in the legislation process; please describe their } \\
\text { nature and mandate? }\end{array}$ \\
\hline & $\begin{array}{l}3.5 \text { Were success or failure of similar legislations in the past or in other } \\
\text { countries or regions were studied? }\end{array}$ \\
\hline & $\begin{array}{l}\text { 3.6 Would you describe this legislation to be primarily based on an example } \\
\text { from another country or region? }\end{array}$ \\
\hline & $\begin{array}{l}\text { 3.7 Were resources (financial, human, technical), costs and benefit, and } \\
\text { monetary return to exchequer or any such factors were also considered? }\end{array}$ \\
\hline \multirow[t]{2}{*}{ 4. Power } & 4.1 Were there resources mobilised to get the legislation passed? \\
\hline & $\begin{array}{l}4.2 \text { Were the distinct position or influence of actors involved, either } \\
\text { organisational or individual, influenced the legislative outcome? }\end{array}$ \\
\hline \multirow{5}{*}{$\begin{array}{l}\text { To ascertain the extent } \\
\text { to which power is } \\
\text { exercised and } \\
\text { composition of power, } \\
\text { i.e. binary or } \\
\text { fragmented, in forging } \\
\text { and enacting public }\end{array}$} & $\begin{array}{l}\text { 4.3 Were there any particular circumstances that helped in the legislation } \\
\text { process? }\end{array}$ \\
\hline & $\begin{array}{l}\text { 4.4 How much your own position and standing helped in the legislation } \\
\text { process? }\end{array}$ \\
\hline & $\begin{array}{l}\text { 4.5 How did your participation and role in the legislation help you } \\
\text { politically? }\end{array}$ \\
\hline & $\begin{array}{l}\text { 4.6 How would you describe the process in case of this particular } \\
\text { legislation, i.e. complex, straightforward, please explain? }\end{array}$ \\
\hline & $\begin{array}{l}\text { 4.7 Would you say to have this legislation passed, formal authority or } \\
\text { numeric strength had played some role? }\end{array}$ \\
\hline 5. Contestation & $\begin{array}{l}\text { Were there any opposing or differing groups or individuals towards this } \\
\text { legislation? }\end{array}$ \\
\hline $\begin{array}{l}\text { To explore how } \\
\text { identities are shaped }\end{array}$ & $\begin{array}{l}\text { What strategies were employed by these groups or individuals to affect the } \\
\text { legislation process? }\end{array}$ \\
\hline
\end{tabular}




\begin{tabular}{|c|c|}
\hline \multicolumn{2}{|c|}{$\begin{array}{l}\text { Annexure 1.1: } \\
\text { Discussion Guidelines - Providers }\end{array}$} \\
\hline Contentions & Guidelines \\
\hline \multirow{8}{*}{$\begin{array}{l}\text { and positions jostled, } \\
\text { between the actors } \\
\text { involved, as well as } \\
\text { contestation of } \\
\text { knowledge and power } \\
\text { in influencing public } \\
\text { policy. }\end{array}$} & Were their views incorporated or addressed in the legislation? \\
\hline & Were there any compromises made towards this legislation? \\
\hline & $\begin{array}{l}\text { Were there any individuals or organisations that changed their stance during } \\
\text { the course of the legislation process, i.e. from supportive to being opponent? }\end{array}$ \\
\hline & What were the challenges during the course of this legislation? \\
\hline & Were there any surprises or unexpected incidents, please recall? \\
\hline & $\begin{array}{l}\text { Given the opportunity, what would have you done differently for this } \\
\text { particular piece of legislation? }\end{array}$ \\
\hline & $\begin{array}{l}\text { At any stage, were there instances when the issue was politicised purely for } \\
\text { the purpose of gaining political mileage? }\end{array}$ \\
\hline & $\begin{array}{l}\text { Were there any actors or organisations that played a balancing or bridging } \\
\text { role? }\end{array}$ \\
\hline
\end{tabular}


Annexure 1.2:

Study Guidelines - Supporters

\begin{tabular}{|c|c|}
\hline Contentions & Guidelines \\
\hline 1. Pre-interpretation / & 1.1 Why you think this piece of legislation was necessary? \\
\hline $\begin{array}{l}\text { interpretation } \\
\text { To identify the }\end{array}$ & $\begin{array}{l}\text { 1.2 Do you think this issue existed for sometime, if yes then why this } \\
\text { legislation could have been passed into law during the tenure of the last } \\
\text { government, what factors were at play to make it successful? }\end{array}$ \\
\hline problem how it is & 1.3 After passing of this legislation, what benefits you expect this to bring? \\
\hline represented in policy & 1.4 When did you first take up this issue to press for legislation? \\
\hline $\begin{array}{l}\text { and to ascertain the } \\
\text { conceptual premise or }\end{array}$ & $\begin{array}{l}\text { 1.5 Who had first introduced you to this issue, from a legislative } \\
\text { perspective? }\end{array}$ \\
\hline $\begin{array}{l}\text { logic that underpin the } \\
\text { same in its }\end{array}$ & $\begin{array}{l}\text { 1.6 What sources, organisational, individual, or literature, did you } \\
\text { personally or asked to explore to learn about this issue? }\end{array}$ \\
\hline representation. & $\begin{array}{l}\text { 1.7 Were you mandated by your organisation or a specific platform to } \\
\text { pursue/support this legislation? }\end{array}$ \\
\hline 2. Identity & $\begin{array}{l}\text { 2.1 Which organisations or individuals you think were crucial for making } \\
\text { this legislation happen? }\end{array}$ \\
\hline
\end{tabular}

To assess how different actors view individuals and organisations involved and how their identities are shaped in the public policy process.

a) How would you describe their role, i.e. positive, critical, constructive, please explain?

2.2 Were there any actors or organisation that might have tried to impede the process?

a) Why they were against the proposed legislation?

b) What were the reasons because of which they were unsuccessful?

c) How would you personally describe your role in the legislative process?

2.2 Were there any organisations or individuals who gained popularity, importance or fame because of passing of this legislation?

2.3 Were there other organisations or individuals whose mandate was to advocate for this particular legislation?

3. Knowledge

3.1 Who provided technical inputs towards framing this legislation?

3.2 Were practical dimensions of the implementation of this legislation were

To highlight the considered?

instrumental

3.3 Were there any other options or provisions considered for this legislation, which were dropped due to impracticality? extent to which it is used in framing public

3.4 Were experts involved in the legislation process; please describe their 


\begin{tabular}{|c|c|}
\hline \multicolumn{2}{|c|}{$\begin{array}{l}\text { Annexure 1.2: } \\
\text { Study Guidelines - Supporters }\end{array}$} \\
\hline Contentions & Guidelines \\
\hline \multirow[t]{4}{*}{ policy solutions. } & nature and mandate? \\
\hline & $\begin{array}{l}\text { 3.5 Were success or failure of similar legislations in the past or in other } \\
\text { countries or regions were studied or influenced how legislation was drafted? }\end{array}$ \\
\hline & $\begin{array}{l}\text { 3.6 Would you describe this legislation to be primarily based on an example } \\
\text { from another country or region? }\end{array}$ \\
\hline & $\begin{array}{l}\text { 3.7 Were resources (financial, human, technical), costs and benefit, and } \\
\text { monetary return to exchequer or any such factors were also considered? }\end{array}$ \\
\hline \multirow[t]{2}{*}{ 4. Power } & 4.1 Were there resources mobilised to get the legislation passed? \\
\hline & $\begin{array}{l}\text { 4.2 Were the distinct position or influence of actors involved, either } \\
\text { organisational or individual, influenced the legislative outcome? }\end{array}$ \\
\hline \multirow{5}{*}{$\begin{array}{l}\text { To ascertain the extent } \\
\text { to which power is } \\
\text { exercised and } \\
\text { composition of power, } \\
\text { i.e. binary or } \\
\text { fragmented, in forging } \\
\text { and enacting public } \\
\text { policy solution. }\end{array}$} & $\begin{array}{l}\text { 4.3 Were there any particular circumstances that helped in the legislation } \\
\text { process? }\end{array}$ \\
\hline & $\begin{array}{l}\text { 4.4 How much your own position and standing helped in the legislation } \\
\text { process? }\end{array}$ \\
\hline & $\begin{array}{l}4.5 \text { How did your participation and role in the legislation help you } \\
\text { professionally? }\end{array}$ \\
\hline & $\begin{array}{l}\text { 4.6 How would you describe the process in case of this particular } \\
\text { legislation, i.e. complex, straightforward, please explain? }\end{array}$ \\
\hline & $\begin{array}{l}4.7 \text { Would you say to have this legislation passed, formal authority or } \\
\text { numeric strength had played some role? }\end{array}$ \\
\hline \multirow{7}{*}{$\begin{array}{l}\text { 5. Contestation } \\
\text { To explore how } \\
\text { identities are shaped } \\
\text { and positions jostled, } \\
\text { between the actors } \\
\text { involved, as well as } \\
\text { contestation of } \\
\text { knowledge and power } \\
\text { in influencing public } \\
\text { policy. }\end{array}$} & $\begin{array}{l}\text { Were there any opposing or differing groups or individuals towards this } \\
\text { legislation? }\end{array}$ \\
\hline & $\begin{array}{l}\text { What strategies were employed by these groups or individuals to affect the } \\
\text { legislation process? }\end{array}$ \\
\hline & Were their views incorporated or addressed in the legislation? \\
\hline & $\begin{array}{l}\text { Were there any compromises made towards this legislation due to pressure } \\
\text { from differing/opposing groups? }\end{array}$ \\
\hline & $\begin{array}{l}\text { Were there any individuals or organisations that changed their stance during } \\
\text { the course of the legislation process, i.e. from supportive to opposing? }\end{array}$ \\
\hline & What were the challenges during the course of this legislation? \\
\hline & Were there any surprises or unexpected incidents, please recall? \\
\hline
\end{tabular}


Annexure 1.2:

Study Guidelines - Supporters

\begin{tabular}{|l|l|}
\multicolumn{1}{|c|}{ Contentions } & \multicolumn{1}{c}{ Guidelines } \\
\hline & $\begin{array}{l}\text { Given the opportunity, what would you have done differently for this } \\
\text { particular piece of legislation? }\end{array}$ \\
\cline { 2 - 3 } & $\begin{array}{l}\text { At any stage, were there instances when the issue was politicised purely for } \\
\text { the purpose of gaining political mileage? }\end{array}$ \\
\cline { 2 - 3 } & $\begin{array}{l}\text { Were there any actors or organisations that played a balancing or bridging } \\
\text { role? }\end{array}$
\end{tabular}




\begin{tabular}{|c|c|}
\hline \multicolumn{2}{|c|}{$\begin{array}{l}\text { Annexure 1.3: } \\
\text { Study Guidelines - Controllers }\end{array}$} \\
\hline Contentions & Guidelines \\
\hline \multirow{2}{*}{$\begin{array}{l}\text { 1. Pre-interpretation / } \\
\text { interpretation }\end{array}$} & 1.1 Do you think this piece of legislation was necessary? \\
\hline & $\begin{array}{l}1.2 \text { When this issue existed for sometime, then why this legislation could } \\
\text { have been passed into law during the tenure of the last government, what } \\
\text { factors were at play to make it successful? }\end{array}$ \\
\hline \multirow{5}{*}{$\begin{array}{l}\text { To identify the problem } \\
\text { how it is represented in } \\
\text { policy and to ascertain } \\
\text { the conceptual premise } \\
\text { or logic that underpin } \\
\text { the same in its } \\
\text { representation. }\end{array}$} & $\begin{array}{l}1.3 \text { After passing of this legislation, do you expect this legislation to bring } \\
\text { any benefits? }\end{array}$ \\
\hline & $\begin{array}{l}\text { 1.4 When did you first come across this issue from a legislative } \\
\text { perspective? }\end{array}$ \\
\hline & $\begin{array}{l}\text { 1.5 Who had first introduced you to this issue, from a legislative } \\
\text { perspective? }\end{array}$ \\
\hline & $\begin{array}{l}\text { 1.6 Were you required exploring organisational, individual, or literature } \\
\text { sources to learn about this issue? }\end{array}$ \\
\hline & $\begin{array}{l}\text { 1.7 Did you follow the mandate of your Department to pursue/support this } \\
\text { legislation? }\end{array}$ \\
\hline \multirow{4}{*}{$\begin{array}{l}\text { 2. Identity } \\
\text { To assess how different } \\
\text { actors view individuals } \\
\text { and organisations } \\
\text { involved and how their } \\
\text { identities are shaped in }\end{array}$} & $\begin{array}{l}\text { 2.1 Which organisations or individuals you think were crucial for making } \\
\text { this legislation happen? }\end{array}$ \\
\hline & $\begin{array}{l}\text { a) How would you describe their role, i.e. positive, critical, constructive, } \\
\text { please explain? }\end{array}$ \\
\hline & $\begin{array}{l}2.2 \text { Were there any actors or organisation that tried to impede the process, } \\
\text { from within your department perhaps? }\end{array}$ \\
\hline & a) Why they were against the proposed legislation? \\
\hline \multirow{4}{*}{$\begin{array}{l}\text { the public policy } \\
\text { process. }\end{array}$} & b) What were the reasons because of which they were unsuccessful? \\
\hline & c) How would you personally describe your role in the legislative process? \\
\hline & $\begin{array}{l}2.2 \text { Were there any organisations or individuals who gained popularity, } \\
\text { importance or fame because of passing of this legislation? }\end{array}$ \\
\hline & $\begin{array}{l}2.3 \text { Were there other organisations or individuals whose mandate was to } \\
\text { advocate for this particular legislation? }\end{array}$ \\
\hline \multirow[t]{2}{*}{ 3. Knowledge } & 3.1 Who provided technical inputs towards framing this legislation? \\
\hline & $\begin{array}{l}3.2 \text { Were practical dimensions of the implementation of this legislation } \\
\text { were considered? }\end{array}$ \\
\hline $\begin{array}{l}\text { To highlight the } \\
\text { instrumental } \\
\text { dimensions and the }\end{array}$ & $\begin{array}{l}3.3 \text { Were there options or provisions considered for this legislation, which } \\
\text { were dropped due to impracticality? }\end{array}$ \\
\hline
\end{tabular}


Annexure 1.3:
Study Guidelines - Controllers

\begin{tabular}{l|l}
\multicolumn{1}{c|}{ Contentions } & \multicolumn{1}{c}{ Guidelines } \\
\hline extent to which it is & 3.4 Were experts involved; please describe their nature and mandate? \\
\cline { 2 - 2 } $\begin{array}{l}\text { used in framing public } \\
\text { policy solutions. }\end{array}$ & $\begin{array}{l}3.5 \text { Were success or failure of similar legislations in the past or in other } \\
\text { countries or regions were studied or influenced how legislation was } \\
\text { drafted? }\end{array}$
\end{tabular}

3.6 Would you describe this legislation to be primarily based on an example from another country?

3.7 Were resources (financial, human, technical), costs and benefit, and monetary return to exchequer or any such factors were also considered?

\section{Power}

4.1 Were there resources mobilised to get the legislation passed?

To ascertain the extent

to which power is

exercised and

4.2 Were the distinct position or influence of actors involved, either

composition of power,

i.e. binary or

fragmented, in forging

and enacting public

policy solution.

organisational or individual, influenced the legislative outcome?

4.3 Were there any particular circumstances that helped in the legislation process?

4.4 How much your own position and standing played a role in the legislation process?

4.5 Did your participation and role in the legislation help you professionally?

4.6 How would you describe the process in case of this particular legislation, i.e. complex, straightforward, please explain?

4.7 Would you say to have this legislation passed, formal authority or numeric strength had played some role?

\section{Contestation}

5.1 Were there any opposing or differing groups or individuals towards this legislation?

To explore how 5.2 What strategies were employed by these groups or individuals to affect

identities are shaped and positions jostled, between the actors involved, as well as contestation of knowledge and power in influencing public policy. the legislation process?

5.3 Were their views incorporated or addressed in the legislation?

5.4 Were there any compromises made towards this legislation due to pressure from differing/opposing groups?

5.5 Were there any individuals or organisations that changed their stance during the course of the legislation process, i.e. from supportive to opposing?

5.6 What were the challenges during the course of this legislation? 
Annexures

Annexure 1.3:

Study Guidelines - Controllers

\begin{tabular}{|l|l|}
\hline \multicolumn{1}{|c|}{ Contentions } & \multicolumn{1}{c|}{ Guidelines } \\
\hline & 5.7 Please recall if there were any surprises or unexpected incidents? \\
\cline { 2 - 3 } & $\begin{array}{l}5.8 \text { At any stage, were there instances when the issue was politicised purely } \\
\text { for the purpose of gaining political mileage by any group/individual? }\end{array}$ \\
\cline { 2 - 3 } & $\begin{array}{l}5.9 \text { Were there any actors or organisations that played a balancing or } \\
\text { bridging role? }\end{array}$ \\
\hline
\end{tabular}





\section{BIBLIOGRAPHY}

\section{A}

AASHA, The AASHA Experience: A Decade of Struggle Against Sexual Harassment in Pakistan (Islamabad: Mehergarh Research and Publications, 2011)

Adeney, K., "A Step Towards Inclusive Federalism in Pakistan? The Politics of the 18th Amendment," The Journal of Federalism, Vol. 42, No. 4 (2012): 539 - 565

Aeberhard-Hodges, J., "Sexual Harassment in Employment: Recent Judicial and Arbitral Trends," International Labour Review, Vol. 135, No. 5 (2006): 499 - 533

Aggarwal, D. D., History and Development of Education in India: Principles and Practice of Elementary Education in India, Vol. 3 (New Delhi: Sarup and Sons, 2002)

Agh, A., "Post-Accession Crisis in the New Member States: Progressing or Backsliding in the EU?" Studies of Transition States and Societies, Vol. 2, No. 1 (2010): 74 - 93

Ahmad, S., Leaders of Change: Drawing Lessons from Case Studies of Organizations with AntiSexual Harassment Policies (Islamabad: Mehergarh, 2010)

Ahmed, S., and Khwaja, S. Z., "Pakistan - A Struggle with Democracy: An Analysis about the Democratic Quality of Pakistan," International Journal of Social Ecology and Sustainable Development, Vol. 4, No. 1 (2013): 108 - 144

Ahmar, M., "Conflict Prevention and the New Provincial Map of Pakistan: A Case Study of Hazara Province," Journal of Political Studies, Vol. 20, No. 2 (2013): 1-19

Akhtar, F., "Organ Transplantation Law in Pakistan to Curb Kidney Trade: Chance for Global Reflection," NDT Plus, Vol. 2 (2008): 128 - 129

Akhtar, F., "Chronic Kidney Disease, Transplantation Practices and Transplantation Law in Pakistan, Opportunity for a Global Meditation," Artif Organs, Vol. 33, No. 7 (2009): 570 - 576

Akhtar, F., and Bari, Omar H., "Living-Unrelated Kidney Selling in Pakistan: Can Organ Transplantation Law and Social Action Create a New Model for Developing Countries?" World Medical and Health Policy, Vol. 2, No. 2 (2010): 133 - 146

Ali, Chaudhri M., The Emergence of Pakistan (New York \& London: Columbia University Press, 1967)

Ali, F., and Kramar, R., "An Exploratory Study of Sexual Harassment in Pakistan Organizations," Asia Pacific Journal of Management, Vol. 32, No. 1 (2015): 229 - 249

Ali, S., "Why does Policy Fails? Understanding the Problems of Policy Implementation in Pakistan Neuro-Cognitive Perspective," International Studies In Educational Administration, Vol. 34, No. 1 (2006): 2 - 20

Ali, Azra A., "Empowerment and Political Mobilization of Women in Pakistan: A Descriptive Discourse of Perspectives," Pakistan Journal of Social Sciences, Vol. 32, No. 1 (2012): $221-228$

Allern, Elin H. and Bale, T., "Political Parties and Interest Groups: Disentangling Complex Relationship," Party Politics, 18.1 (2012) 7 - 25

Allmendinger, P., New Labour and Planning: From New Right to New Left (Abingdon, Oxon: Routledge, 2011)

Alvarez, M., Cheibub, Jose A., Limongi, F., and Przeworski, A., "Classifying Political Regimes," Studies in Comparative International Development, Vol. 31, No. 2 (996): 3 - 36

Anderson, James E., Public Policymaking, 8th ed. (Stamford: Cengage Learning: 2003)

Anderson, James E., Public Policymaking: An Introduction (Boston: Houghton Mifflin Company, 2003) 
Ansell, C., "Network Institutionalism," R. A. W. Rhodes, Sarah A. Binder and Bert A. Rockman (eds.) The Oxford Handbook of Political Institutions (Oxford: Oxford University Press, 2006): 75 - 89

Aranson, Peter H., "Theories of Economic Regulation: From Clarity to Confusion," Journal of Law \& Politics, Vol. 6, No. 1 (1989-1990): 247 - 286

Armstrong, David A., "Stability and Change in the Freedom House Political Rights and Civil Liberties Measures," Journal for Peach Research, Vol. 48, No. 5 (2011): 755 - 771

Armingeon, K., "The Effects of Negotiation Democracy: A Comparative Analysis," European Journal of Political Research, Vol. 41 (2002): 81 - 105

Ashraf, Muhammad I., "The Democratic Stature of Pakistan in the Contemporary World: Challenges and Prospects," The South Asianist, Vol. 2, No. 2 (2013) 119 - 127

Ashraf, O., Ali, S., Ali, Sumbul A., Ali, H., Alam, M., Ali, A., and Ali, Talaha M., "Attitude Toward Organ Donation: A Survey in Pakistan," Artificial Organs, Vol. 29, No. 11 (2005): $899-905$

Atkinson, R., Held, G., and Jaffares, S., "Theories of Discourse and Narrative," in Rob Atkinson, Terizakis Georgios, Karsten Zimmermann (eds.) Sustainability in European Environmental Policy: Challenges of Governance and Knowledge (New York: Routledge, 2011): Chapter 6

Awan, Shehzadi, Z., "Role of Civil Society in Empowering Pakistani Women," South Asian Studies, Vol. 27, No. 2 (2012): $439-458$

Ayres, I. and Braithwaite, J., Responsive Regulation (Oxford, Oxford University Press, 1992)

$\mathrm{B}$

Bacchi, Carol L., "Policy as Discourse: What does it mean? Where does it get us?" Discourse: Studies in the Cultural Politics of Education, Vol. 21, No. 1 (2000): 45 - 57

Bacchi, Carol L., Analysing Policy: What's the Problem Represented to be? (Frenchs Forest, NSW: Pearson Education, 2009)

Bacchi, Carol L., Women, Policy and Politics: The Construction of Policy Problems (London: Sage, 1999)

Baldwin, R., Cave, M. and Lodge, M., "Introduction: Regulation - The Field and the Developing Agenda," (pp. 3 - 16) in Robert Baldwin, Martin Cave and Martina Lodge (eds.) The Oxford Handbook of Regulation (New York: Oxford University Press, 2010)

Baldwin, R., Scott, C., and Hood, C., A Reader on Regulation (Oxford: Oxford University Press, 1998)

Baldwin, R. and Cave, M., Understanding Regulation: Theory, Strategy and Practice (New York: Oxford University Press, 1999)

Ball, Stephen J., Politics and Policy Making in Education: Exploration in Policy Sociology (New York: Routledge, 1990)

Ball, Stephen J., "What is Policy? Texts, Trajectories and Toolboxes," Discourse, Vol. 13, No. 2 (1993): $9-17$

Ball, Stephen J., "Introducing Monsieur Foucault", (pp. 1 - 8) in Stephen J. Ball (ed.) Foucault and Education: Disciplines and Knowledge (London: Routledge, 1990):

Baloch, B., "What's in a Name?" Foreign Policy, April 26, 2010

Bandura, R., A Survey of Composite Indices Measuring Country Performance (New York: United Nations Development Programme, 2008)

Barbaros, C., "Do Issues Decide? Thematic and Partisan Ideational Strategies in Electoral Debates," Argumentum Journal, Vol. 10, No. 1 (2012): 113 - 132

Barber, Benjamin, R., Participatory Politics for a New Age (Barkley and Los Angeles: University of California Press, 2003)

Bartolini, S. and Mair, S., "Challenges to Contemporary Political Parties," (pp: 327 - 343) in Larry Diamond and Richard Gunther (eds.) Political Parties and Democracy (Baltimore: The Johns Hopkins University Press, 2001) 
Annexures

Bashir, M., "Public Policy Processes and Citizen Participation in Pakistan,” (pp. 395 - 408) in Meghna Sabharwal (ed.) Public Administration and Public Policy: Public Administration in South Asia: India, Bangladesh and Pakistan (London: CRC Press, 2013)

Baxter, C., "Constitution Making: The Development of Federalism in Pakistan," Asia Survey, Vol. 14, No. 12 (1974): 1074 - 1085

Becker, Gary S., "A Theory of Competition among Pressure Groups for Political Influence," The Quarterly Journal of Economics, Vol. 98, No. 3 (1983): 372 - 400

Becker, Gary S., “The Public Interest Hypothesis Revisited: A New Test of Peltzman's Theory of Regulation," Public Choice, Vol. 49, No. 3 (1986): 223 - 234

Beecher, Janice A., "The Prudent Regulator: Politics, Independence, Ethics and the Public Interest," Energy Law Journal, Vol. 29, No. 2 (2008): pp. 577 - 614

Beitz, Charles R., The Idea of Human Rights (Oxford: Oxford University Press, 2009)

Bellamy, R., Liberalism and Pluralism: Towards a Politics of Compromise (London: Routledge, 1999)

Béland, D., "Ideas and Institutional Change in Social Security: Conversion, Layering, and Policy Drift," Social Science Quarterly, Vol. 88, No. 1 (2007): 20 - 38

Béland, D., “The Idea of Power and Role of Ideas," Political Studies Review, Vol. 8, No. 2 (2010): $145-154$

Béland, D., "Ideas and Social Policy: An Institutional Perspective," Social Policy and Administration, Vol. 39, No. 1 (2005): $1-18$

Béland, D., and Cox, Robert H., "Ideas and Politics," in Daniel Béland and Robert H. Cox (eds.) Ideas and Politics in Social Science Research (Oxford: Oxford University Press, 2011): $3-22$

Bell, J., Populism and Elitism: Politics in the Age of Equality (Washington D.C.: Regnery Publishing, 1992)

Bell, S., "The Power of Ideas: The Ideational Shaping of the Structural Power of Business," International Studies Quarterly, Vol. 56 (2012): 661 - 673

Bell, S., “Do We Really Need a New 'Constructivist Institutionalism' to Explain Institutional Change?” British Journal of Political Science, Vol. 41, No. 4 (2011): 883 - 906

Bengali, K., "History of Educational Policy Making and Planning in Pakistan," Working Paper Series \# 40 (Islamabad: Sustainable Development Policy Institute, 1999)

Bennett, Colin J., "Review Article: What is Policy Convergence and what causes it?" British Journal of Political Science, Vol. 21, No. 2 (1991): 215 - 233

Berg, B., "Public Choice, Pluralism and Scarcity: Implication for Bureaucratic Behavior," Administration \& Society, Vol. 16, No. 1 (1984): $71-82$

Berry, Frances S. and Berry, William D., "State Lottery Adoption as Policy Innovations: An Event History Analysis," The American Political Science Review, Vol. 84, No. 2 (1990): $395-415$

Besant, A., "The Case for India," the Presidential Address Delivered by Annie Besant at the ThirtySecond Indian National Congress Held at Calcutta December 26, 1917

Besley, T. and Case, A., "Political Institutions and Policy Choices: Evidence from the United States," Journal of Economic Literature, Vol. 41, No. 1 (2003): 7 - 73

Best, H. and Higley, J., Democratic Elitism: New Theoretical and Comparative Perspectives (Boston, MA: Brill Academic Publishers, 2010)

Bhatia, G., "Demystifying the Feminine Self," International Journal of Technological Exploration and Learning, Vol. 2, No. 6 (2013): $322-326$

Bile, K.M., Qureshi, J.A.R.H., Rizvi, S.A.H., Naqvi, S.A.A., Usmani, A.Q., and Lashari, L.A., "Human Organ and Tissue Transplantation in Pakistan: When a Regulation Makes a Difference," Eastern Mediterranean Health Journal, Vol. 16 (2010): S161

Berg, B., "Public Choice, Pluralism and Scarcity: Implication for Bureaucratic Behavior," Administration \& Society, Vol. 16, No. 1 (1984): $71-82$ 
Bernstein, M., Regulating Business by Independent Commission (Princeton, NJ: Princeton University Press, 1955)

Berry, Frances S. and Berry, William D., "Innovation and Diffusion Models in Policy Research," (pp. 223 - 260) in Paul A. Sabatier (ed.), Theories of the Policy Process (Boulder, Colorado: Westview Press, 2007)

Birkland, Thomas A., An Introduction to Policy Process: Theories, Concepts and Models of Public Policy Making, 3rd ed. (New York: M.E. Sharpe, 2011)

Black, J., "Regulatory Conversation," Journal of Law and Society, Vol. 29, No. 1 (2002): 163 - 196

Black, J., "Critical Reflections on Regulation,” Australian Journal of Legal Philosophy, Vol. 27 (2002): $1-35$

Blackmore, J. and Lauder, H., "Research Policy," in B. Somekh and C. Lewin (eds.), Research Methods in Social Sciences (London: Sage, 2005): 97 - 104

Blood, Peter R. Pakistan: A Country Study, 6th ed. (Washington D.C.: Federal Research Division, 1995)

Blyth, Mark M., Great Transformation: Economic Ideas and Institutional Change in the Twentieth Century (Cambridge, UK: Cambridge University Press, 2002)

Blyth, Mark M., "Any More Bright Ideas? The Ideational Turn of Comparative Political Economy," Comparative Politics, Vol. 29, No. 2 (1997): 229 - 250

Bobrow, Davis B. and Dryzek, J., Policy Analysis by Design (Pittsburgh, PA: University of Pittsburgh Press, 1987)

Bolt, W., “Jean-Jacques Laffont, Regulation and Development,” De Economist, Vol. 154, No. 2 (2006): $317-318$

Bové, P., "Discourse," in Frank Lentricchia, Thomas McLaughlin (eds.) Critical Terms for Literary Study (Chicago: University of Chicago Press, 1990)

Braithwaite, J., Crime, Shame and Reintegration (Cambridge, Cambridge University Press, 1989)

Brohi, N. and Akbar, Usman A. (eds.) Situational Analysis on Sexual Harassment at Work Place (Islamabad: AASHA, 2003)

Brinkerhoff, Derick W., Governance in Post-Conflict Societies: Rebuilding Fragile States (New York: Routledge, 2007)

Brink, Margo van den and Metze, T., "Words matter in Policy and Planning," (pp. 13 - 19) in Margo van den Brink and Tamara Metze (eds.) Words Matter in Policy and Planning (Utrecht, Labor Grafimedia, 2006)

Braithwaite, J., Crime, Shame and Reintegration (Cambridge, Cambridge University Press, 1989)

Brooks, J., "Policies and Institutions in Transition Economies: A Political Economy Perspective on the Agri-Food Sector," Food Policy, Vol. 20, No. 6 (1995): 487 - 500

Brownlee, J., "Portents of Pluralism: How Hybrid Regimes Affect Democratic Transaction," American Journal of Political Science, Vol. 53, No. 3 (2009): p. 515 - 532

Brookfield, S., The Power of Critical Theory for Adult Learning and Teaching (Berkshire: Open University Press: 2005)

Buchstein, H. and Jörke, D., “The Argumentative Turn toward Deliberative Democracy: Habermas's Contribution and the Foucauldian Critique," (pp: 271 - 304) in Frank Fischer, Herbert Gottweis (eds.) The Argumentative Turn Revisited: Public Policy as Communicative Practice (Durham: Duke University Press, 2012)

Burks, Ardath W., "Constitution-making in Pakistan,” Political Science Quarterly, 69.4 (1954): 541 564

Cairney, P., Understanding Public Policy: Theories and Issues (London: Palgrave MacMillan, 2012)

Cairney, P., "Standing on the Shoulders of Giants: How Do We Combine the Insights of Multiple Theories in Public Policy Studies?" Policy Studies Journal, Vol. 41, No. 1 (2013): 1 21

Calhoun, C., "Civil Society and the Public Sphere,” Public Culture, 5 (1993): 267 - 280 
Callard, K., Pakistan: A Political Study (New York: The Macmillan Company, 1957)

Calvert, Randall L., McCubbins, Mathew D., and Weingast, Barry R., "A Theory of Political Control and Agency Discretion," American Journal of Political Science, Vol. 33, No. 3 (1989): $588-611$

Campbell, John L., "Institutional Reproduction and Change,” (pp. 87 - 115) in Glenn Morgan, John L. Campbell, Colin Crouch, Ove Kaj Pederson and Richard Whitley (eds.), The Oxford Handbook of Comparative Institutional Analysis (Oxford: Oxford University Press, 2010)

Campbell, John L., "What do we Know - Or Not - About Ideas or Politics?” (pp. 157 - 176) in Peter Nedergaard and John L. Campbell (eds.) Politics and Institutions (Copenhagen: DJOEF, 2008)

Campbell, John L., "Institutional Analysis and the Role of Ideas in Political Economy," Theory and Society, Vol. 27, No. 3 (1998): 377 - 409

Campbell, John L., "Ideas, Politics, and Public Policy," Annual Review of Sociology, Vol. 28 (2002): $21-38$

Campbell, John L. Institutional Change and Globalization (Princeton: Princeton University Press, 2004)

Carafa, L., "When the Birds Fly Together. A Framework for Analysing International and Domestic Factors Behind Policy Diffusion and Convergence," paper presented at the Italian Political Science Association Twenty-third Annual Conference, Rome, Italy, 17 - 19 September 2009

Carothers, T., "Political Party Aid: Issues for Reflection and Discussion," (pp. 10 - 30) in Helena Bjuremalm (ed.) Supporting Political Party Systems: Experiences and Challenges (Stockholm: Swedish International Development Cooperation Agency, 2005)

Cassinelli, C. W., "Reflections on the Concept of the Public Interest," Ethics, Vol. 69, No. 1 (1958): $48-61$

Cassum, Laila A., "Verbal Violence at Work Place: A Reality from Pakistani Context," Journal of Nursing Education and Practice, Vol. 4, No. 8 (2014): 20 - 25

Carrigan, C. and Coglianese, C., "The Politics of Regulation: From New Institutionalism to New Governance," (pp. 107 129) The Annual Review of Political Science, Vol. 14, No. 1 (2011): $107-129$

Carothers, T., "The End of the Transition Paradigm," Journal of Democracy, Vol. 13, No. 1 (2002): 5 $-21$

Chapman, Audrey R., "Development of Indicators for Economic, Social and Cultural Rights: The Rights to Education, Participation in Cultural Life and Access to the Benefits of Science," (pp. 111 - 152) in Yvonne Donders and Vladimir Volodin (eds.) Human Rights in Education, Science and Culture: Legal Development and Challenges (Burlington: Ashgate Publishing, 2007)

Chazournes, L., "Monitoring, Supervision and Coordination of the Standard Setting Instrument of UNESCO," (pp. 51 - 72) in Abdulqawi A. Yusuf (ed.) Normative Action in Education, Science and Culture: Essay in Commemoration of the Sixtieth Anniversary of UNESCO (Leiden: Martinus Nijhoff, 2007)

Choudhury, G.W., "Constitution-making Dilemmas in Pakistan," The Western Political Quarterly, Vol. 8, No. 4 (1955): $589-600$

Choudhury, G. W., "The Constitution of Pakistan," Pacific Affairs, 29.3 (1956): 243 - 252

Christensen, Jorgen G., "Competing Theories of Regulatory Governance: Reconsidering Public Interest Theory of Regulation," (pp. 96 - 110) in David Levi-Faur (ed.) Handbook on the Politics of Regulation (Cheltenham: Edward Elgar, 2011)

Chumil, Marisa L., Rodriguez, Diana G., and Boyd, Michelle L., "The Struggle for Rights: Pakistani Muslim Women in Pakistan and how to Support Advocacy Efforts," PRAXIS, Vol. 9, Fall (2009): 45 - 53

Clarke, M., Regulation: The Social Control of Business between Law and Politics (New York: Palgrave Macmillan, 1999) 
Annexures

Coase, Ronald, H., "The Problem of Social Cost," Journal of Law and Economics, Vol. 3 (1960): 1 44

Cochran, C., Mayer, L., Carr, T. and Cayer, N., American Public Policy: An Introduction, 9th ed. (Boston, MA: Wadsworth Cengage Learning, 2006)

Cochran, C. and Malone, E. Public Policies: Perspectives and Choices (Boston: McGraw-Hill College, 1999)

Cochran, Clarke E., "Political Science and the Public Interest," Southern Political Science Association, Vol. 36, No. 2 (1974): pp. 327 - 355

Collier, D., Laporte, J., and Seawright, J., "Typologies: Forming Concepts and Creating Categorical Variables," (pp. 152 - 173) in Janet M. Box-Steffensmeier, Henry E. Brady, and David Collier (eds.), The Oxford Handbook of Political Methodology (Oxford: Oxford University Press, 2015)

Connor, C., "Recent Development: The United States' Second and Third Periodic Report to the United Nations Human Rights Committee," Harvard International Law Journal, Vol. 49, No. 2 (2008): 509 - 534

Consumer Rights Commission of Pakistan, The Process of Law Making (Islamabad: Al-Rehman Printers, 2005)

Cook, B., "Arenas of Power in Climate Change Policymaking," Policy Studies Journal, Vol. 38, No. 3 (2010): $465-486$

Coomaraswamy, R., "Human Security and Gender Violence," Economic and Political Weekly, Vol. 40, No. 44/45 (2005): 4729 - 4736

Coplan, I., "The Princely States, the Muslim League, and the Partition of India in 1947," The International History Review, Vol. 13, No. 1 (1991): 38 - 69

Coppedge, M., Alvarez, A. and Maldonado, C., "Two Persistent Dimensions of Democracy: Contestation and Inclusiveness," The Journal of Politics, Vol. 70, No. 3 (2008), 632 647

Craig, John E., "Implementing Educational Policies in Sub-Saharan Africa: A Review of the Literature," World Bank Discussion Paper: Education and Training Series (1987)

Croley, Steven P., "Theories of Regulation: Incorporating the Administrative Process," Columbia Law Review, Vol. 98, No. 1 (1998): 1 - 168

Croley, Steven P., Regulation and Public Interest: The Possibility of Good Regulatory Governance (Princeton: Princeton University Press, 2008)

Croley, Steven P., "Public Interest Regulation," Florida State University Law Review, Vol. 28, No. 7 (2000): pp. $7-107$

Cronbach, Lee L., "Beyond the Two Disciplines of Scientific Psychology," American Psychologist, Vol. 30, No. 2 (1975): $116-127$

Cuzán, Alfred G., “An Analysis of Regime Type in Iberoamerica: 1973-1983," Journal of Developing Societies, Vol. 4, No. 2 (1988): 180 - 193

\section{$\mathrm{D}$}

Dahl, Robert A., Polyarchy: Participation and Opposition (New Heaven: Yale University Press, 1971)

Dahlberg, L., "Discourse Theory as Critical Media Politics? Five Questions," (pp. 41 - 63) in Lincoln Dahlberg and Sean Phelan (eds.) Discourse Theory and Critical Media Politics (New York: Palgrave MacMillan, 2011)

Daugherty, R. and Ecclestone, K., "Constructing Assessment for Learning in the UK Policy Environment," (pp. 149 - 168) in John Gardner (ed.) Assessment and Learning (London: Sage, 2006)

Daugherty, R., "Mediating Academic Research: The Assessment Reform Group Experience,” (pp. 21 - 36) in John Furlong and Alis Oancea (eds.) Assessing Quality in Applied and Practice-based Research in Education (Abingdon, Oxon: Routledge, 2008) 
Defeis, Elizabeth F., "The United Nations and Women - A Critique," William \& Mary Journal of Women and the Law, Vol. 17, No. 2 (2011): 395 - 432

Deleon, P., "The Historical Roots of the Field," (pp. 39 - 57) in Michael Moran, Martin Rein and Robert E. Goodin (eds.) The Oxford Handbook of Public Policy (Oxford: Oxford University Press, 2006)

Deleon, P. and Vogenbeck, Danielle M., "The Policy Science at the Crossroads," (pp. 3 - 14) in Frank Fischer, Gerald J. Miller and Mara S. Sidney (eds.), Handbook of Public Policy Analysis: Theory, Politics and Methods (Boca Raton, FL: CRC Press, 2007)

Den Hertog, J., "General Theories of Regulation," (pp. 223 - 270) in B. Bouckaert and G. de Geest (eds.), Encyclopedia of Law and Economics: Volume III. The Regulation of Contracts (Cheltenham: Edward Elgar, 2000)

Denk, T., "How to Measure Polyarchy with Freedom House: A Proposal for Revision," Quality and Quantity, Vol. Vol. 47, No. 6 (2013): 3457 - 3471

Derthick, M., and Quirk, Paul J., The Politics of Deregulation (Washington D.C.: The Brookings Institution, 1985)

Djankov, S., et al., "The Regulation of Entry," The Quarterly Journal of Economics, Vol. 117, No. 1 (2000): $1-37$

Diamond, L. "Elections Without Democracy: Thinking About Democracy," Journal of Democracy, Vol. 13, No. 2 (2002): $21-35$

Diamond, L., “Thinking about Hybrid Regimes," Journal of Democracy, Vol. 13, No. 2 (2002): 21 35

Dibadj, Reza R., Rescuing Regulation (New York: State University of New York, 2006)

Doern, G. B., and Phidd, R. W., Canadian Public Policy: Ideas, Structure, Process, 2nd ed. (Toronto: Nelson Canada, 1992)

Doren, Peter Van, "Review the Regulation and Public Interest: The Possibility of Good Regulatory Governance by Steven P. Croley," Cato Journal, Vol. 28, No. 1 (2008): 164 - 174

Downey, J. and Fenton, N., "New Media, Counter Publicity and the Public Sphere," New Media and Society, 5.2 (2003): $185-202$

Drinan, Robert F., The Mobilization of Shame: A World View of Human Rights (New Haven: Yale University Press, 2001)

Dumbleton, P., “A Philosophy of Education for All?” British Journal of Special Education, Vol. 17, No. 1 (1990): $16-18$

Durrani, N., "Pakistan: Curriculum and the Construction of National Citizen," in (pp. 221 - 240) Mah-e-Rukh Ahmed (ed.) Education in West Central Asia (London: Bloomsbury Academic, 2013)

Đurić, I., "The New Institutionalism(s): A Framework for the Study of Public Policy in Post-conflict and Post-communist Countries," Politička Misao, Vol. 48, No. 5 (2011): 85 - 105

Dye, Thomas R. Understanding Public Policy, 13th ed. (New York, Prentice Hall, 2007)

Dye, Thomas R., Understanding Public Policy (Englewood Cliffs, N.J.: Prentice Hall, 1972)

Dye, Thomas R., Zeigler H. and Schubert, L., The Irony of Democracy: An Uncommon Introduction to American Politics, fifteenth ed. (Boston, MA: Wadsworth, Cengage Learning, 2012)

\section{E}

Easton, D., Systems Analysis of Political Life (New York: John Wiley \& Sons, Inc., 1965)

Echeverri-Gent, J., The State and the Poor: Public Policy and Political Development in India and the United States (California: University of California Press, 1993)

Efrat, A., "Combating the Kidney Commerce," Civil Society against Organ Trafficking in Pakistan and Israel," British Journal of Criminology, Vol. 53 (2013): 764 - 783

Efrat, A., "The Politics of Combating the Organ Trade: Lessons from the Israeli and Pakistani Experience," American Journal of Transplantation, Vol. 13 (2013) 
Eisner, Marc A., Worsham, J. and Ringquist, Evan J., Contemporary Regulatory Policy, 2nd ed. (Boulder CO: Lynne Rienner, 2006)

Ethier, D., "Democratic Consolidation," (pp. 259 - 284) in Abdo I. Baaklini and Helen Desfosses (eds.) Designs for Democratic Stability: Studies in Viable Constitutionalism (New York: M. E. Sharpe, Inc., 1997)

Evans. M., Policy Transfer in Global Perspective (Burlington, Ashgate Publishing, 2004)

Evans, M., "Policy Transfer in Critical Perspective," Policy Studies, Vol. 30, No. 3 (2009): 243 - 268

$\mathrm{F}$

Faden-Kuhne, K., and Gabriel, Oscar W., "Mapping Political Participation," (pp. 33 - 70) in Oscar W. Gabriel, Silke I. Keil and Eric Kerrouche (eds.) Political Participation in France and Germany (Colchester, ECPR Press, 2012)

Fairclough, N. Discourse and Social Change (Cambridge, Polity Press: 1992)

Fawcett, B., Goodwin, S., Meagher, G., and Phillips, R., Social Policy for Social Change (Melbourne: Palgrave MacMillan. 2010)

Federal Bureau of Statistics, Pakistan Social and Living Standard Measurement Survey (Islamabad: Statistic Division, 2013): Section 2.2

Fenton, N., "Multiplicity, Autonomy, New Media and the Networked Politics of New Social Movement," (pp. 178 - 200) in Lincoln Dahlberg and Sean Phelan (eds.) Discourse Theory and Critical Media Politics (New York: Palgrave MacMillan, 2011)

Fiorina, M., "Rational Choice and the New (?) Institutionalism," Polity, Vol. 28, No. 1 (1995): 107 115

Fischer, F., Reframing Public Policy: Discursive Politics and Deliberative Practices (Oxford: Oxford University Press, 2003)

Fischer, F., Miller, Gerald J., and Sidney, Mara S. (eds.), Handbook of Public Policy Analysis: Theory, Politics and Methods (Boca Raton, FL: CRC Press, 2007)

Flathman, R. E., The Public Interest: An Essay Concerning the Normative Discourse of Politics (New York: Wiley, 1966)

Foote, Catherine E. and Frank, Arthur W., "Foucault and Therapy: The Disciplining of Grief," (pp. 157 - 188) in Adrienne S. Chambon, Allen Irving and Laura Epstein (eds.) Reading Foucault for Social Work (New York: Columbia University Press, 1983)

Foucault, M., The archaeology of knowledge, A. M. Sheridan-Smith, (trans.) (London: Tavistock, 1972)

Fraser, Arvonne S., "Becoming Human: The Origins and Development of Women's Human Rights," Human Rights Quarterly, Vol. 21, No. 4 (1999): 853 - 906

Freedom House. Freedom in the World 2008: The Annual Survey of Political Rights in Civil Liberties (Maryland: Rowman \& Littlefield Publishers, 2008)

Friedman, Barry D., Regulation in the Regan-Bush Era: The Eruption of Presidential Influence (Pittsburgh: University of Pittsburgh Press, 1995): pp. 7 - 19

\section{G}

Gable, Richard W., "Interest Groups as Policy Shapers," Annals of the American Academy of Political and Social Science, 139 (1958): $84-93$

Galston, William A., Liberal Pluralism: The Implications of Value Pluralism for Political Theory and Practice (Cambridge: Cambridge University Press, 2002)

Garceau, O., "Interest Group Theory in Political Research," Annals of the American Academy of Political and Social Science, 139 (1958):

Garrett, G. and Weingast, B., "Ideas, Interest and Institutions: Constructing the European Community's Internal Market," (pp. 173 - 206) in Judith Goldstein and Robert Keohane (eds.) Ideas and Foreign Policy (Ithaca NY, Cornell University Press, 1993) 
Garwood, P., "Dilemma Over Live-Donor Transplantation," Bulletin of the World Health Organization, Vol. 85 (2007): 1 - 84

Giannone, D., "Political and ideological aspects in the measurement of democracy: the Freedom House case", Democratization, Vol. 17: No. 1 (2010): 68 - 97

Gilbert, L., and Mohseni, P., "Beyond Authoritarianism: The Conceptualization of Hybrid Regimes," Studies in Comparative International Development, Vol. 46 (2011): p. 270 - 297

Gilani, Syed A., "Ghost Schools in Pakistan," (pp. 40 - 44) Gareth Sweeney, Krina Despota and Samira Lindner (eds.) Global Corruption Report: Education (Abingdon: Routledge, 2013)

Gillham, B., Case Study Research Method (London: Continuum, 2010)

Gobo, G., "Re-conceptualizing Generalization: Old Issues in a New Frame," (pp. 193 - 213) in Pertti Alasuutari, Leonard Bickman, and Julia Brannen (eds.) The Sage Handbook of Social Research Methods (London: SAGE Publications, 2008)

Goetz, J.P. and LeCompte, Margaret D., Ethnography and Qualitative Design in Education Research (Orlando, FL, Academic Press, 1984)

Gomery, D., "Public Policy," (pp. 618 - 620) in William A. Darity Jr. (ed.) International Encyclopedia of the Social Sciences, 2nd ed., Vol. 6 (Detroit: MacMillan, 2008)

Gooby-Taylor, P., "Ideas and Policy Change," (pp. 1 - 11) in Peter Taylor-Gooby (ed.) Ideas and Welfare Sate Reform in Western Europe (New York, Palgrave Macmillan, 2005)

Goodin, Robert E., Rein, M., and Moran, M., "The Public and its Policies," (pp. 3 - 38) in Michael Moran, Martin Rein and Robert E. Goodin (eds.) The Oxford Handbook of Public Policy (Oxford: Oxford University Press, 2006)

Goodwin, S., "Analysing Policy as Discourse: Methodological Advances in Policy Analysis,” (pp. 167 - 180) in Lina Markauskaite, Peter Freebody and Jude Irwin (eds.) Methodological Choice and Design: Scholarship, Policy and Practice in Social and Educational Research (London: Springer, 2011)

Goodwin, S., "Women, Policy and Politics: Recasting Policy Studies," (pp. 25 - 36) in Angelique Bletsas, Chris Beasley (eds.) Engaging with Carol Bacchi: Strategic Interventions and Exchanges (Adelaide: University of Adelaide Press, 2012)

Goodwin, N., "Governmentality in the Queensland Department of Education: Policies and the Management of Schools," Discourse, Vol. 17, No. 1 (1996): 65 - 74

Gouin, Rodolphe and Harguindéguy, Jean-Baptiste, "The Use of Cognition in Policy Analysis: A First Appraisal," Journal of Public Administration and Governance, Vol. 2, No. 1 (2012): $1-20$

Greenberg, George D., Miller, Jeffrey A., Mohr, Lawrence B. and Vladeck, Bruce C., "Developing Public Policy Theory: Perspectives from Empirical Research," American Political Science Association, Vol. 71, No. 4 (1977): 1532 - 1543

Greenberg, George D. et al, Case Study Aggregation and Policy Theory (University of Michigan, Institute of Public Policy Studies, 1973)

Gruber, J. E., Smith, M., and Kauppinen-Toropainen, K., "Sexual Harassment Types and Severity: Linking Research and Policy," (pp. 151 - 173) in Margaret S Stockdale (ed.) From Sexual Harassment in the Workplace: Perspectives, Frontiers, and Response Strategies (Thousand Oaks: Sage Publications, 1996)

Groosman, B., "Pollution Tax," (pp. 538 - 568) in (eds.) Boudewijn Bouckaert and Gerrit De Geest, Encyclopedia of Law \& Economics, Volume II. Civil Law and Economics (Cheltenham: Edward Elgar, 2000)

Grugel, J., Democratization: a Critical Introduction (New York: Palgrave, 2002)

Guba, Egon G., and Lincoln, Yvonna S., "Epistemological and methodological bases of naturalistic inquiry," Educational Communication and Technology Journal, Vol. 30 (1982): 233 $-252$

Gugiu, Mihaiela R., and Centallas, M., "The Democracy Cluster Classification Index," Political Analysis, Vol. 21 (2013): $334-349$ 
Gunningham, N. and Sinclair, D. Smart Regulation: Designing Environmental Policy (Oxford: Clarendon Press, 1998)

\section{$\mathrm{H}$}

Haas, Stans de, Sexual Harassment in a Male Dominated Workplace (Delft: Eburon Uitgeverij B.V., 2009)

Habib, R. Imran and Zahraa, M., "Judicial Independence in Pakistan: A Brief Historical Account," Harvard Asia Quarterly, Vol. XIV, No. 2 (2012): 25 - 32

Howarth, D., "The Method of Articulation," (pp. 23 - 42) in Margo van den Brink and Tamara Metze (eds.) Words Matter in Policy and Planning (Utrecht, Labor Grafimedia, 2006)

Hägg, P. Göran T., "Theories on the Economics of Regulation: A Survey of the Literature from a European Perspective," European Journal of Law and Economics, Vol. 4, No. 4 (1997): $337-370$

Haggard, S., and Kaufman, Robert R., "Democratization During the Third Wave," The Annual Review of Political Science, Vol. 19 (2016): 125 - 144

Hajer, Maarten A., "Doing Discourse Analysis: Coalitions, Practices, Meaning," (pp. 65 - 74) in Margo van den Brink and Tamara Metze (eds.) Words Matter in Policy and Planning: Discourse Theory and Method in the Social Sciences (Utrecht: Netherlands Graduate School of Urban and Regional Research, 2006)

Hajer, Maarten A., The Politics of Environmental Discourse (Oxford: Clarendon, 1995)

Hall, Peter A., The Political Power of Economic Ideas: Keynesianism Across Nations (Princeton University Press, 1989)

Hall, Peter A., "Policy Paradigms, Social Learning and the State: The Case of Economic Policymaking in Britain," Comparative Politics, Vol. 25, No. 3 (1993): 275 - 296

Hall, Peter A. and Taylor, Rosemary C. R., "Political Science and the Three New Institutionalism," Political Studies, Vol. 44, No. 5 (1996): 936 - 957

Hamel, J., "Case Study Methods," Qualitative Research Methods, Vol. 32 (Thousands Oaks CA: Sage, 1993)

Hancher, L. and Moran, M., "Organizing Regulatory Space," in Leigh Hancher and Michael Moran (eds.) Capitalism, Culture and Economic Regulation (Oxford: Clarendon Press, 1989)

Haqani, H., Op-Ed appeared on July 4, 2003 on Carnegie [accessed April 142014 (http://carnegieendowment.org/2003/07/04/u.s.-should-stop-indulgingmusharraf/39jc?reloadFlag=1)]

Haqqani, H., "History Repeats Itself in Pakistan," Journal of Democracy, Vol. 17, No. 4 (2006): 110 124.

Harberger, A., "Monopoly and Resource Allocation," The American Economic Review, Vol. 44, No. 2 (1954): $77-87$

Hass, Peter M., "Epistemic Communities and International Policy Coordination," International Organization, Vol. 46, No. 1 (1992): 1 - 35

Hass, Peter M., "Do Regimes Matter? Epistemic Communities and Mediterranean Pollution Control," International Organization, Vol. 43, No. 3 (1989): 377 - 403

Hay, C., "The 'Crisis' of Keynesianism and the Rise of Neoliberalism in Britain: An Ideational Institutionalist Approach" (pp. 193 - 218) in John L. Campbell and Ove Pedersen (eds.) The Rise of Neoliberalism and Institutional Analysis (Princeton: Princeton University Press, 2001)

Hay, C., "Constructivist Institutionalism," (pp. 56 - 74) in R. A. W. Rhodes, Sarah A. Binder and Bert A. Rockman (eds.) The Oxford Handbook of Political Institutions (Oxford: Oxford University Press, 2006)

Hay, C., and Wincott, D., "Structure, Agency and Historical Institutionalism," Political Studies, Vol. 46, No. 4 (1998): 951 - 957

Hussain, M. and Ali, K., The AASHA Experience: A Decade of Struggle Against Sexual Harassment in Pakistan (Islamabad: Mehergarh, 2011) 
Hantke-Domas, M., "The Public Interest Theory of Regulation: Non-Existence or Misinterpretation?" European Journal of Law and Economics, Vol. 15, No. 2 (2003): 165 - 194

Heclo, H. Modern Social Politics in Britain and Sweden (New Haven: Yale University Press, 1974)

Held, V., The Public Interest and Individual Interest (New York: Basic Books, 1970)

Heracleous, L. Images of Discourse: Interpretive, Functional, Critical and Structurational (Cambridge: Cambridge University Press, 2006)

Hill, M. (ed.), Studying Public Policy: An International Approach (Bristol: Policy Press, 2014)

Hogler, R. and Gross, Michael A., "Journal Ranking and Academic Research: Two Discourses About the Quality of Faculty Work," Management Communication Quarterly, Vol. 23, No. 1 (2009): 839 - 861

Högström, J., "Classification and Rating of Democracy," Taiwan Journal of Democracy, Vol. 9, No. 2 (2013): $33-54$

Hood, C., Explaining Economic Policy Reversals (Buckingham: Open University Press, 1994)

Hood, C., et al, Regulation Inside Government: Waste-Watchers, Quality Police and Sleaze-Busters (Oxford: Oxford University Press, 1999)

Howlett, M. and Ramesh, M. Studying Public Policy: Policy Cycles and Policy Subsystems, 2nd ed. (Don Mills, ON: Oxford University Press, 2003)

Hrebenar, Ronald J. and Morgan, Bryson B., Lobbying in America: A Reference Handbook (Santa Barbara: ABC-CLIO Inc., 2009)

Huang, R., "On the Nature of Public Policy," Chinese Public Administration Review, Vol. 1, No. 3/4 (2002): $275-282$

Human Rights Commission of Pakistan, State of Human Rights in 2012 (Lahore: HRCP, 2013)

Humphrey, John P., "The International Bill of Rights: Scope and Implementation," William and Mary Law Review, Vol. 17, No. 3 (1976): 527 - 541

Huntington, Samuel P., "The Marasmus of the ICC: The Commission, the Railroads, and the Public Interest," The Yale Law Journal, Vol. 61, No. 4 (1952): 467 - 509

Huntington, Samuel P., The Third Wave: Democratization in Late Twentieth Century (Norman: University of Oklahoma Press, 1991)

\section{I}

Ilyas, M., Alam, M. and Ahmad, H., "The Islamic Perspective of Organ Donation in Pakistan," Saudi Journal of Kidney Diseases and Transplantation, Vol. 20, No. 1 (2009): 154 - 156

Imam, A. and Dar, E. A., Democracy and Public Administration in Pakistan (Boca Raton: CRC Press, 2014)

J

Jacobs, Scott H., "The Gold Age of Regulation," CEPMLP Research Network, Vol. 7, Article 13 (2000)

Jafar, Tazeen H., "Organ Trafficking: Global Solutions for a Global Problem," American Journal of Kidney Disease, Vol. 54, No. 6 (2009): 1145 - 1157

Jahn, D., and Müller-Rommel, F., "Political Institutions and Policy Performance: A Comparative Analysis of Central and Eastern Europe," Journal of Public Policy, Vol. 30, No. 1 (2010): $23-44$

James, O., "Regulation Inside Government: Public Interest Justification and Regulatory Failures," Public Administration, Vol. 78, No. 2 (2000): p. 327 - 343

Jette, Diane U., Grover, L., and Keck, Carol P., "A Qualitative Study of Clinical Decision Making in Recommending Discharge Placement from the Acute Care Setting," Physical Therapy, Vol. 83, No. 3 (2003): $224-236$

Jobert, B. and Muller, P., L'Etat en Action (Paris: PUF, 1987)

Jobert, B., "The Normative Framework of Public Policy," Political Studies, Vol. 37 (1989): 376 - 386 
Annexures

John, P., "Is there Life After Policy Streams, Advocacy Coalitions and Punctuations: Using

Evolutionary Theory to Explain Policy Change," The Policy Studies Journal, Vol. 31, No. 4 (2003): $481-498$

John, P., Analyzing Public Policy, 2nd ed. (Abingdon: Routledge, 2012)

Johnson, Ollie A., "Pluralist Authoritarianism in Comparative Perspective: White Supremacy, Male Supremacy, and Regime Classification," (pp. 116 - 136) in Georgia Anne Persons (ed.) Race and Ethnicity in Comparative Perspective (New Jersey: Transaction Publishers, 1999)

Jordana, J. and Levi-Faur, D., "The Politics of Regulation in the Age of Governance," (pp. 1 - 28) in Jacint Jordana and David Levi-Faur (eds.) The Politics of Regulation: Institutions and Regulatory Reforms for the Age of Governance (Cheltenham: Edward Elgar, 2004)

Joskow, Paul L. and Rose, Nancy L., "The Effects of Economic Regulation," (pp. 1450 - 1506) in Richard Schmalensee and Robert D. Willig (eds.) Handbook of Industrial Organization, Vol. II (North-Holland, Amsterdam1989)

Joskow, Paul L. and Noll, Roger G., "Regulation in Theory and Practice: An Overview," (pp. 1 - 78) in Gary Fromm (ed.) Studies in Public Regulation (Cambridge, MA: The MIT Press, 1981)

\section{K}

Kagan, Robert A., "Review of the Regulation and Public Interest: The Possibility of Good Regulatory Governance by Steven P. Croley," Law and Politics Book Review, Vol. 18, No. 7 (2008): 640 - 644

Kalia, S., "Bureaucratic Policy Making in Pakistan," The Dialogue, Vol. 8, No. 2 (2013): 156 - 170

Kalhan, A., "Gray Zone" Constitutionalism and the Dilemma of Judicial Independence in Pakistan," Vanderbilt Journal of Transitional Law, Vol. 46, No. 1 (2013): 1 - 96

Kamran, T., "Early Phase of Electoral Politics in Pakistan: 1950s," South Asian Studies, Vol. 24, No. 4 (2009): $257-283$

Kazim, Syed F., "Organ Donation Law in Pakistan: An Overview of the Current Situation," Journal of Pakistan Medical Association, Vol. 58, No. 2 (2008): 99 - 100

Karlberg, I. and Schersten, T., "Human Organ Transplantation," World Health Forum, Vol. 10, No. 2 (1989): $228-234$

Keeler, Theodore, E., "Theories of Regulation and the Deregulation Movement," Public Choice, Vol. 44, No. 1 (1984): pp. $103-145$

Kenez, P., A History of the Soviet Union from the Beginning to the End, second edition (Cambridge: Cambridge University Press, 2006)

Kerr, C., The Future of Industrial Societies: Convergence or Continuing Diversity? (Cambridge: Harvard University Press, 1983)

Khan, Akhtar H., "Education in Pakistan: Fifty Years of Neglect," The Pakistan Development Review, Vol. 36, No. 4 (1997): 647 - 667

Khan, A., "Policy-making in Pakistan's Population Programme," Health Policy and Planning, Vol. 11, No. 1 (1996): 30 - 51

Khan, H., Constitutional and Political History of Pakistan (Oxford: Oxford University Press, 2001): 141; see also: Stavsky, Mark M., "The Doctrine of State Necessity in Pakistan," Cornell International Law Journal, Vol. 16 (1983): 341 - 394

Khan, S., "The Struggle for the Rights of Women in Pakistan," (pp. 184 - 199) in Shahida Murtaza (ed.) Understanding Women's Issues: A Feminist Standpoint, (Saarbrücken: Lambert Academic Publications, 2012)

Khan, Muhammad A., "A new experiment in democracy in Pakistan," Annals of the American Academy of Political and Social Sciences, Vol. 358 (1965): 109 - 113

Khan, Z., "Constitutional Reforms in Pakistan: Federalism after the 18th Amendment," (pp. 193 215) in Christian J. Hegemer and Hanns Bühler (eds.) Federalism in Asia and Beyond (München: Hanns-Seidel-Stiftung, 2013 
Khawaja, S., Public Policy: Formulation Implementation Analysis: Pakistan Focused (Islamabad: Mr. Books, 2013)

King, Stephen M., Chilton, Bradley S. and Roberts, Gary E., "Reflections on Defining the Public Interest," Administration \& Society, Vol. 41, No. 8 (2010): 954 - 978

Kingdon, John W., Agendas, Alternatives, and Public Policies (New York: HarperCollins. 1995)

Kloppenberg, James T., "Institutionalism, Rational Choice, and Historical Analysis," Polity, Vol. 28 No. 1 (1995): 125 - 128

Kling, Robert W., "Building an Institutionalist Theory of Regulation," Journal of Economic Issues, Vol. 22, No. 1 (1988): 197 - 209

Korson, J. H., and Maskiell, M., "Islamization and Social Policy in Pakistan: The Constitutional Crisis and the Status of Women." Asian Survey, Vol. 25, No. 6 (1985): $589-612$

Knill, C. and Tosun, J., Public Policy: A New Introduction (Hampshire: Palgrave MacMillan, 2012)

Koelble, T., "The New Institutionalism in Political Science and Sociology," Comparative Politics, Vol. 27, No. 2 (1995): $231-243$

Krasner, S., "Approaches to the State: Alternative Conceptions and Historical Dynamics," Comparative Politics, Vol. 16 (1984): 223 - 246

Kritzman, L. D., (ed.) M. Foucault: Politics, Philosophy, Culture: Interviews and Other Writings 1977-1984 (New York: Routledge, 1988)

Krueger, Anne O., "The Political Economy of the Rent Seeking Society," American Economic Review, Vol. 64, No. 3 (1974): pp. $291-303$

$\mathrm{L}$

Lange, B., "Regulatory Spaces and Interaction: An Introduction," Social \& Legal Studies, Vol. 12, No. 4 (2003): $411-423$

Lange, B., "Understanding Regulatory Law: Empirical Versus Systems-theoretical Approaches?" Oxford Journal of Legal Studies, Vol. 18, Autumn (1998): 450 - 471

Lange, S. and Schimank, U., "A Political Sociology for Complex Societies: Niklas Luhmann," (pp. 60 - 70) in Kate Nash and Alan Scott (eds.) The Blackwell Companion to Political Sociology (Malden; Oxford; Victoria: Blackwell Publishing, 2004):

Lasswell, Harold D., "The Policy Orientation," (pp. 3 - 15) in Daniel Lerner and Harold D. Lasswell (eds.) The Policy Sciences: Recent Development in Scope and Method (Stanford: Stanford University Press, 1951)

Legro, Jeffrey W., "The Transformation of Policy Ideas," American Journal of Political Science, Vol. 44, No. 3 (2000): $419-432$

Lee, Charlene H., Sexual Harassment of Women in the American Work Place, Executive Research Report S34 (Washington D.C.: The Industrial College of the Armed Forces, 1991)

Levi-Faur, D., "Regulation and Regulatory Governance," (pp. 3 - 21) in David Levi-Faur (ed.) Handbook on the Politics of Regulation (Cheltenham: Edward Elgar, 2011)

Levi-Faur, D. and Jordana, J., "The Making of a New Regulatory Order," The Annals of the American Academy of Political and Social Science, Vol. 598, No. 6 (2005): 6 - 9

Levitsky, S., and Way, Lucan A., "Elections Without Democracy: The Rise of Competitive Authoritarianism," Journal of Democracy, Vol. 13, No. 2 (2002): 51 - 66

Levy, B. and Spiller, Pablo T., "The Institutional Foundation of Regulatory Commitment: A Comparative Analysis of Telecommunication Regulation," Journal of Law, Economics \& Organization, Vol. 10, No. 2 (1994): 201 - 246

Leys, W. A. R. and Perry, C. M., Philosophy and the Public Interest (Chicago: Committee to Advance Original Work in Philosophy, 1959)

Lieberman, Robert C., "Ideas, Institutions and Political Order: Explaining Political Change," The American Political Science Review, Vol. 96, No. 4 (2002): 697 - 712

Lilley III, W., and Miller, James C., "The New "Social Regulation”," Public Interest, Vol. 47, Spring (1977): $49-61$ 
Lincoln, Yvonna S., and Guba, Egon G., (pp. 27 - 44) "The Only Generalization is: There is no Generalization," in Roger Gomm, Martyn Hammersley and Peter Foster (eds.) Case Study Method (London, Sage, 2000)

Lincoln, Yvonna S. and Guba, Egon G., Naturalistic Inquiry (London: SAGE Publications, 1978)

Lockwood, G., Rosenthal, P. and Budjanovcanin, A., "Sexual Harassment Litigation in Britain: A Window on the Socially Irresponsible Workplace," Tamara Journal, Vol. 6, No. 4 (2007): $132-144$

Lowi, Theodore J., "Four Systems of Policy, Politics and Choice," Public Administration Review, Vol. 32, No. 4 (1972): $298-310$

Lynggaard K., "Ideas in EU Decision Making: Towards a Typology of Ideas and Ideational Change," (pp. 209-236) in Steen Scheuer and John Damm Scheuer (eds.) The Anatomy of Change - A Neo-institutionalist Perspective (Copenhagen: Copenhagen Business School Press, 2008)

$\mathrm{M}$

Malik, Iftikhar H., "Military Coup in Pakistan: Business As Usual or Democracy on Hold," The Round Table, 360 (2001): 357 - 377

Malik, A., "Pakistan in 2013: A Milestone in Democratic Transition," Asia Survey, Vol. 54, No. 1 (2014): $177-189$

Mantzana, V. et al., "Identifying Healthcare Actors Involved in the Adoption of Information System," European Journal of Information Systems, Vol. 16 (2007): 91 - 102

March, James G., and Olsen, Johan P., "Elaborating the "New Institutionalism," (pp. 3 - 22) in R. A. W. Rhodes, Sarah A. Binder, and Bert A. Rockman (eds.) The Oxford Handbook of Political Institutions (Oxford: Oxford University Press, 2006)

March, James G. and Olsen, John P., "The New Institutionalism: Organizational Factors in Political Life," The American Political Science Review, Vol. 78. No. 3 (1984): 734 - 749

Mason, M., "Sample Size and Saturation in PhD Studies Using Qualitative Interviews," Forum: Qualitative Social Research, Vol. 11, No. 3 (2010): Art. 8

Marshall, A., Principles of Economics (London: Macmillan and Co., Ltd., 1890)

McChesney, Fred S., "Rent Extraction and Rent Creation in the Economic Theory of Regulation," The Journal of Legal Studies, Vol. 16, No. 1 (1987): pp. $101-118$

McConnell, S., "The Old Institutionalism and the New," Polity, Vol. 40, No. 3 (2008): 326 - 331

McCool, Daniel C., Public Policy Theories, Models and Concepts: An Anthology (New Jersey: Prentice-Hall, 1995)

McCubbins, Mathew D., Noll, Roger G. and Weingast, Barry R., "Administrative Procedures as Instruments of Political Control," Journal of Law, Economics \& Organization, Vol. 3, No. 2 (1987): $243-277$

McMahon, E., and Kornheiser, E., "Assessing the Assessors: Correlating Democracy Methodologies," Social Indicators Research, Vol. 97, No. 2: 269 - 277

Meier, Kenneth J., Regulation: Politics, Bureaucracy and Economics (New York: St. Martin's Press, 1985)

Meier, Kenneth J., The Politics of Sin: Drugs, Alcohol, and Public Policy (New York: M. E. Sharpe, Inc., 1994)

Merkens, H., "Selection Procedure, Sampling, Case Construction," (pp. 165 - 171) in Uwe Flick, Ernst von Kardorff and Ines Steinke (eds.) A Companion to Qualitative Research (London: Sage, 2004)

Merriam, Sharan B. and Tisdel, Elizabeth J., Qualitative Research: A Guide to Design and Implementation (San Francisco: John Wiley \& Sons, 2015)

Messina, A., "Public Relations, the Public Interest and Persuasion: An Ethical Approach," Journal of Communication Management, Vol. 11, No. 1 (2007): 29 - 52

Miller, Johnston K., and McTavish D., Making and Managing Public Policy (Abingdon: Routledge, 2014) 
Mills, C. W., The Power Elite, new edition (Oxford: Oxford University Press, 2000)

Ministry of Education, Education for All: Mid Decade Assessment Pakistan Country Report 2008 (Islamabad, Government of Pakistan, 2008)

Ministry of Education, Development of Education in Pakistan 1990 - 1992: Country Report for the 43rd Session of International Conference on Education (Islamabad: Government of Pakistan, 1992)

Ministry of Education, National Plan of Action on Education for All 2001 - 2015 (Islamabad, Government of Pakistan, 20023)

Ministry of Education, National Education Policy 2009 (Islamabad, Ministry of Education, 2009)

Mitchell, Clyde J., "Case and Situation Analysis," The Sociological Review, Vol. 31, No. 2 (1983): $187-211$

Mitnick, Barry M., “A Typology of Conception of Public Interest,” Administration \& Society, Vol. 8, No. 1 (1976): pp. 5 - 28

Mitnick, Barry M., The Political Economy of Regulation (Ney York: Columbia University Press, 1980)

Miyakawa, T. (ed.), The Science of Public Policy: Essential Readings in Policy Sciences, pt. 1 (London: Routledge, 1999)

Moazam, F., and Jafarey, A., "Pakistan's Experience with Kidney Transplantation and Trade: A Call for International Solidarity," Indian Journal of Medical Ethics, Vol. 6, No. 3 (2014): $156-162$

Moe, Terry M., "Power and Political Institutions," Perspectives on Politics, Vol. 3, No. 2 (2005): 215 $-233$

Mohiuddin, Yasmin N., Pakistan: A Global Studies Handbook (Santa Barbara: ABC-CLIO Inc, 2007)

Montanye, James A., "On Rent Thinking and the Corruption of Republican Government," The Independent Review, Vol. 7, No. 4 (2003): 519 - 535

Moran, M., "Understanding the Regulatory State," British Journal of Political Science, Vol. 32, No. 2 (2000): $391-413$

Morse, J. M., "Determining Sample Size," Qualitative Health Research, Vol. 10, No. 1 (2000): 3 - 5

Mujahid-Mukhtar, E., Situation Analysis of the Education Sector (Islamabad: UNESCO, 2011)

Mughal, Munir A., Legal and Judicial Education Reforms in Pakistan: Role of Legislature, Judiciary and Executive (Lahore: Munib Book House, 2013): 147 - 148

Mueller, D., Public Choice (Cambridge: Cambridge University Press, 1979)

Muller, P. and Surel, Y. L'analyse des Politiques Publiques (Paris: Editions Montchrestien, 1998)

Muller, P., Les Politiques Publiques (Paris: Presses Universitaires de France, 1990)

Muller, P., "Les Politiques publiques comme Construction d'un Rapport au Monde," in A. Faure, G. Pollet and P. Warin (eds.) La Construction du Sens dans les Politiques publiques: Débat Autour de la Notion de Référentiel (Paris: L'Harmattan, 1995)

Munger, Michael C., "Interest Groups 1," (p. 308) in Charles K. Rowley and Friedrich Schneider (eds.) The Encyclopedia of Public Policy, Vol. 1 (New York: Kluwer Academic Publishes, 2004)

Munir, Muhammad A., Public Interest Litigation in Supreme Court of Pakistan (2007): 66, retrieved from SSRN: http://ssrn.com/abstract=1984583 or http://dx.doi.org/10.2139/ssrn.198458366

Musarrat, R., Ali, G. and Azhar, Muhammad S., "Federalism in Pakistan, Current Developments," International Journal of Academic Research in Business and Social Sciences, Vol. 2, No. 4 (2012): 162 - 162

Musarrat, R., Ali, G. and Azhar, Muhammad S., "18th Amendment and its Impact on Pakistan's Politics," Journal of Sociological Research, Vol. 3, No. 1 (2012)

Mushtaq, M., Muhammad, A. and Alqama, Syed K., "Politics of Power Sharing in Post-1971 Pakistan," Journal of Politics and Law, Vol. 4, No. 1 (2011): 249 - 260

Musselin, C., "The role of Ideas in the Emergence of Convergent Higher Education Policies in Europe: The Case of France," Working Paper Series No. 73, Center for European Studies (2000) 
Mustafa, B. and Brown, Katherine E., "The Taliban, Public Space and Terror in Pakistan," Eurasian Geography and Economics, Vol. 51, No. 4 (2010): 496 - 512

\section{$\mathrm{N}$}

National Education Management Information System, Pakistan Education Statistics 2011 - 12 (Islamabad: Ministry of Education, Trainings and Standards in Higher Education, 2013)

Neyer, J. and Schroeter, M., "Deliberative Europe and the Rejected Constitution," (pp. 61 - 90) in Erik Oddvar Eriksen, Christian Joerges and Florian Rödl (eds.) Law and Democracy in the Post-National Union (Oslo: Center for European Studies, 2006)

Nee, V. and Ingram, P., "Embeddedness and Beyond: Institutions, Exchange, and Social Structure," (pp. $19-45)$ in Marcy C. Brinton and Victor Nee (eds.) The New Institutionalism in Sociology (New York: Russell Sage Foundation, 1998)

Nelson, Barbara I., "Public Policy and Administration: An Overview," (pp. 551 - 592) in Robert E. Goodin and Hans-Dieter Klingemann (eds.), A New Handbook on Political Science (Oxford: Oxford University Press, 1998)

Newton, K. and van Deth, J. W., Foundation of Comparative Politics, 2nd ed. (Cambridge: Cambridge University Press, 2010)

Noll, Roger G., Regulatory Policy and the Social Sciences (California, University of California Press, 1985)

Nowlin, Matthew C., "Theories of the Policy Process: State of the Research and Emerging Trends," The Policy Studies Journal, Vol. 39, No. S1 (2001): 41 - 60

Noorani, M. A., "Commercial Transplantation in Pakistan," British Medical Journal, Vol. 336 (2008): 1378

Offe, C., "The Attribution of Public Status to Interest Groups," (pp. 221 - 258) in Claus Offe (ed.) Disorganized Capitalism, (Cambridge, Ma: The MIT Press, 1985)

Ogus, A., "Evaluating Alternative Regulatory Regimes: The Contribution of Law and Economics," Geoforum, Vol. 30, No. 3 (1999): 223 - 229

Ogus, A., "W(h)ither the Economic Theory of Regulation? What Economic Theory of Regulation?" (pp. 31 - 44) in Jacint Jordana and David Levi-Faur (eds.) The Politics of Regulation: Institutions and Regulatory Reforms for the Age of Governance (Cheltenham: Edward Elgar, 2004)

Olowu, D., International Law: A Textbook for the South Pacific (Washington DC: CDPublishing, 2010)

Osman, Ferdous, A., "Public Policy Making: Theories and their Implications in Developing Countries," Asian Affairs, Vol. 24, No. 3 (2002): 37 - 52

O'toole, James K., "The Economics of the Implementation of Social Policy: Search for the Missing Link," The Social Science Journal, Vol. 26, No. 2 (1989): 115 - 130

P

Padgett, S., Organizing Democracy in Eastern Germany: Interest Groups in Post-Communist Society (Cambridge: Cambridge University Press, 2000)

Pakistan Bureau of Statistics, Agriculture Statistics of Pakistan 2010 - 2011 (Islamabad: Statistics Division, 2013): Table 175

Pakistan Institute of Legislative Development and Transparency, Citizens Report: 5 Years of the $13^{\text {th }}$ National Assembly of Pakistan (Islamabad: PILDAT, 2013) 
Pakistan Institute of Legislative Development and Transparency, Assessment of the Quality of Democracy in First 100 Days of National and Provincial Governments (Islamabad: Pildat, 2013)

Pal, Leslie A., Beyond Policy Analysis: Public Issue Management in Turbulent Times, 4th ed. (Toronto: Nelson, 2010)

Panizza, F. and Miorelli, R., "Taking Discourse Seriously: Discursive Institutionalism and Poststructuralist Discourse Theory," Political Studies, (2012) doi: 10.1111/j.14679248.2012.00967.x

Parsons, W., Public Policy: An Introduction to the Theory and Practice of Policy Analysis (Cheltenham: Edward Elgar, 1995)

Parsons, C., "Showing Ideas as Causes: The Origins of the European Union," International Organization, Vol. 56, No. 1 (2002): $47-84$

Peltzman, S., "Toward a More General Theory of Regulation," Journal of Law and Economics, Vol. 19, No. 2 (1976): pp. $211-240$

Peltzman, S., "The Economic Theory of Regulation after a Decade of Deregulation," Brookings Papers on Economic Activity," Microeconomics, Vol. 1989 (1989): pp. 1 - 59;

Peltzman, S., "Constituent Interest and Congressional Voting," Journal of Law and Economics, Vol. 27, No. 1 (1984): $181-210$

Pesavento, Todd E., "Kidney Transplantation in the Context of Renal Replacement Therapy," Clinical Journal of the American Society of Nephrology, Vol. 4 (2009): 2035 - 2039

Peters, B. Guy, "The Policy Process in Developed and Less Developed Political System," International Journal of Public Administration, Vol. 19, No. 9 (1996): 1639 - 1668

Peters, G., American Public Policy: Promise and Performance (New York: Chatham House, 1999)

Peter Foster (eds.) Case Study Method (London: Sage Publications, 2000)

Phillips S. D., "Discourse, Identity and Voice," Feminist Contributions to Policy Studies," (pp. 242 265) in L. Dobuzinskis, M. Howlett and D. Laycock (eds.) Policy Studies in Canada: The State of the Art (Toronto: University of Toronto Press, 1996)

Phoenix, A., "Enabling Research? Silencing and recognition in social research," (pp. 61 - 78) in Jerome Satterthwiate, Heather Piper and Pat Sikes (eds.) Power in the Academy (London: Trentham Books, 2009)

Pierson, P., "Increasing Returns, Path Dependence, and the Study of Politics," American Political Science Review, Vol. 94, No. 2 (2000): 251 - 267

Pigou, Arthur, C., The Economics of Welfare ( $4^{\text {th }}$ ed.) (London: Macmillan, 1932)

Pio, E. and Syed, J., "Our Bodies, Our Minds, Our Men: Working South Asian Women," Gender in Management: An International Journal, Vol. 28, No. 3 (2013): 140 - 150

Posner, Richard A., The Economics of Justice, (Cambridge, MA: Harvard University Press, 1983)

Posner, Richard A., "Theories of Economic Regulation," The Bell Journal of Economics and Management Science, Vol. 5, No. 2 (1974): pp. 335 - 358

Posner, Richard A., "Taxation by Regulation," The Bell Journal of Economics and Management Science, Vol. 2, No. 1 (1971): pp. $22-50$

Power, M., The Audit Society: Ritual of Verification (Oxford: Oxford University Press, 1997)

Prasad, K., "Women's Movement and Media Action: Paradoxes and Promises," (pp. 213 -244) in Kiran Prasad (ed.) Women and Media: Challenging Feminist Discourse (New Delhi: The Women Press, 2005)

Q

Q.Hirst, P. (ed.), The Pluralist Theory of the State: Selected Writings of G.D.H. Cole, J.N. Figgis, and H.J. Laski (London: Routledge, 2005) 
$\mathrm{R}$

Rawls, J., A Theory of Justice, rev. ed. (Cambridge: Harvard University Press, 2003)

Reagan, Michael D., "The Politics of Regulatory Reform," The Western Political Quarterly, Vol. 36, No. 1 (1983): 149 - 167

Rehman, A., Dynamism of Pakistan's Civil Society: Religious-Secular Rivalry and its Resources," Journal of International Development and Cooperation, Vol. 12, No. 2 (2006): 47 70

Remmer, Karen L., "Exclusionary Democracy,” Studies in Comparative International Development, Vol. 20, No. 4 (1985): $64-85$

Reynolds, L., "Foundation of an Institutional Theory of Regulation," Journal of Economic Issues, Vol. 25, No. 3 (1981): 641 - 656

Riaz, S., "Implementation Mechanism: Protection Against Harassment of Women at workplace," Hamdard Islamicus, Vol. 34, No. 2 (2013): 70 - 78

Rizvi, Adibul H. and Naqvi, S.A.A., "Fallout of Commercialism in Organ Donation as Seen in Pakistan," in Walter Land and John B. Dossetor (eds.) Organ Replacement Therapy: Ethics, Justice, Commerce (Berlin: Springer, 1991): 203 - 205

Rizvi, Adibul H., Naqvi, Syed Ali A., Zafar, Mirza N., and Akhtar, Syed F., "A Kidney Transplantation Model in a Low-Resource Country: An Experience from Pakistan," Kidney International Supplements, Vol. 3 (2013): 236 - 240

Rizvi, Adibul H., Naqvi, S., Zafar, M. N., Hussain, Z., Hashmi, A., Akhtar, F. Hussain, M. and Ahmed, E., "Pakistan Abolishes Kidney Market and Ushers in New Era of Ethical Transplantation," International Journal of Organ Transplantation Medicine, Vol. 1, No. 4 (2010): 193 - 197

Rizvi, Adibul H., "Living Donor Kidney Transplantation in Pakistan," Annals of Transplantation, Vol. 14, No. 1 (2009): 19 - 19

Rose-Ackerman, S., "Deregulation and Reregulation: Rhetoric and Reality," Journal of Law \& Politics, Vol. 6, No. 2 (1990): pp. $287-309$

Rose, Leo E., "Pakistan: Experiment with Democracy," in Larry Diamond, Juan J. Linz and Seymour Martin Lipset (eds.), Democracy in Developing Countries, Vol. 3 - Asia (Colorado: Adamantine Press Limited, 1989): 111 - 141

Rossell, Christine H., "Using Multiple Criteria to Evaluate Public Policies: The Case of School Desegregation," American Politics Quarterly, Vol. 21, No. 2 (1993): 155 - 184

Rowley, Charles K., Tollison, Robert D. and Tullock, G., The Political Economy of Rent Seeking (Boston, Kluwer Academy Publishers, 1988)

Rutherford, M., "The Old and the New Institutionalism: Can Bridges Be Built?" Journal of Economic Issues, Vol. 29, No. 2 (1995): 443 - 451

Russell, J., Greenhalgh, T., Byrne, E. and McDonnell, J., "Recognizing Rhetoric in Health Care Policy Analysis," Journal of Health Sciences Research and Policy, Vol. 13, No. 1 (2008): $40-46$

\section{$\mathrm{S}$}

Sabatier, Paul A., and Jenkins-Smith, H., "The Advocacy Coalition Framework: An Assessment," (pp. 189 - 221) in Paul Sabatier (ed.) Theories of Policy Process, 2nd ed. (Boulder, CO: Westview Press, 1999)

Sabatier, Paul A., "Toward Better Theories of the Policy Process," Political Science and Politics, Vol. 24, No. 2 (1991): 147 - 156

Sabatier, Paul A., (ed.), Theories of the Policy Process (Boulder, Colorado: Westview Press, 2007)

Sachs, I. "What State, What Markets, For What Development? The Social, Ecological and Economical Dimensions of Planning," Social Indicators Research, Vol. 39, No. 3 (1996): $311-320$ 
Saeed, F., Working With Sharks: A Pakistani Woman's Story of Sexual Harassment in United Nations - From Personal Grievance to Public Law (McLean, VA: Advances Press, 2013)

Salisbury, Robert H., "The Analysis of Public Policy: A Search for Theories and Roles," (pp. 151 175) in Austin Ranney (ed.) Political Science and Public Policy (Chicago: Markham Publishing Co., 1968)

Sapru, R. K., Public Policy: Formulation, Implementation and Evaluation, 2nd ed. (New Delhi: Sterling, 2004)

Sayeed, Khalid B., "Pakistan's Basic Democracy," Middle East Journal, 15.3 (1961): 249 - 263

Schneider, A. and Ingram, H., Policy Design for Democracy (Lawrence, University of Kansas Press, 1997)

Schofield, Janet W., "Increasing the Generalizability of Qualitative Research," (pp. 69-97) in Roger Gomm, Martyn Hammersley and Peter Foster (eds.) Case Study Method: Key Issues, Key Texts (London: SAGE Publications, 2000): 75

Schmidt, Vivien A., "Taking Ideas and Discourse Seriously: Explaining Change through Discursive Institutionalism as the Fourth 'New Institutionalism'," European Political Science Review, Vol. 2, No. 1 (2010): $1-25$

Schmidt, Vivien A., "Speaking of Change: Why Discourse is Key to the Dynamics of Policy Transformation," Critical Policy Studies, Vol. 5, No. 2 (2011): 106 - 126

Schmidt, Vivian A., "Ideas and Discourse in Transformational Political Economic Change in Europe," (pp. 36 - 63) in Grace Darlene Skogstad (ed.) Policy Paradigms, Transnationalism, and Domestic Politics (Toronto, University of Toronto Press, 2011)

Schmidt, Vivian A., "Discursive Institutionalism," (pp. 85 - 113) in Frank Fischer and Herbert Gottweis (eds.) The Argumentative Turn Revisited: Public Policy as Communicative Practice (Durham: Duke University press, 2012)

Schmidt, Vivien A., "Comparative Institutional Analysis," (pp. 125 - 143) in Todd Landman and Neil Robinson (eds.) The Sage Handbook of Comparative Politics (London: Sage Publications, 2009)

Schmidt, Vivien A., "Discursive Institutionalism: The Explanatory Power of Ideas and Discourse," Annual Review of Political Science, Vol. 11 (2008): 303 - 326

Schmidt, Vivien A., "Institutionalism and the State," in C. Hay, M. Lister, and D. Marsh (eds.) The State: Theories and Issues (Basingstoke: Palgrave, 2006)

Schmidt, Vivien A., "Reconciling Ideas and Institutions through Discursive Institutionalism," in Daniel Beland and Robert Henry Cox (eds.) Ideas and Politics in Social Science Research (Oxford and New York: Oxford University Press: 2011): Chapter 2

Scott, C., "Analyzing Regulatory Space: Fragmented Resources and Institutional Design," Public Law, Summer (2001): 329 - 353

Schubert, G., The Public Interest (Glencoe, III: Free Press, 1960)

Segrave, K., The Sexual Harassment of Women in the Workplace, 1600 to 1993 (Jefferson NC: McFarland \& Company, 2013)

Self, P., Government by the Market: The Politics of Public Choice (San Francisco: Westview Press, 1993)

Selznick, P., "Focusing Organizational Research on Regulation," (pp. 363 - 368) in Roger G. Noll (ed.) Regulatory Policy and the Social Sciences (Berkeley: University of California Press, 1985)

Shleifer, A., "Understanding Regulation,” European Financial Management, Vol. 11, No. 4 (2005): pp. $439-451$

Shughart II, William F. and McChesney, Fred S., "Public Choice Theory and Antitrust Policy," Public Choice, Vol. 142, No. 3 (2010): pp. 385 - 406

Shah, Azmat A., "Federalism Constraints and Opportunity in Pakistan," African Journal of Political Science and International Relation, Vol. 7, No. 2 (2013): 79 - 99

Shah, F., "The Rise of the Third Sector and its Baneful Impact on Pakistan," Herald Exclusive, April 2014 
Sham, Asma A., "Political Empowerment of Women in Pakistan," Pakistan Vision, Vol. 10 No. 1 (2009): $141-150$

Sharma, S. and Sharma, S. K., Principles and Theory of Political Science (New Delhi: Atlantic Publishers \& Dist., 2000): pp. 406 - 433

Shaw, Sara E., "Reaching the Parts that other Theories and Methods Can't Reach: How and Why a Policy-as-Discourse Approach Can Inform Health-related Policy," Health Vol. 14, No. 2 (2010): 196 - 212

Shimazono, Y., "The State of the International Organ Trade: A Provisional Picture Based on Integration of Available Information," Bulletin of World Health Organization, Vol. 85, No. 12 (2007): $901-980$

Sial, Abdul Quddoos, "Implications of Assorted Constitutional Principles on Administration of Justice in Pakistan," Pakistan Journal of Social Sciences, Vol. 31, No. 2 (2011): 230 $-232$

Sidney, Mara S., "Policy Formulation: Design and Tools," (pp. 79 - 88) in Frank Fischer and Gerald J. Miller (eds.) Handbook of Public Policy Analysis: Theory, Politics, and Methods (Boca Raton: CRC Press, 2007): 84

Sikkink, K. Ideas and Institutions: Developmentalism in Brazil and Argentina (Cornell: Cornell University Press, 1991):

Simoulin, V., "Emission, médiation, réception... Les opérations constitutives d'une réforme par imprégnation," Revue Française de Science Politique, Vol. 50, No. 2 (2000): 333 350

Sloan, John W., "The Policy Capabilities of Democratic Regimes in Latin America," Latin American Research Review, Vol. 24, No. 2 (1989): 113 - 127

Sloan, J. and Tedin, Kent L., "The Consequence of Regime Type for Public Policy Outputs," Comparative Political Studies, Vol. 20, No. 1 (1987): 98 - 124

Smith, Howard R., Democracy and the Public Interest (Athens: University of Georgia Press, 1960): pp. $27-31$

Smith, Kevin B., "Typologies, Taxonomies, and the Benefits of Policy Classification," Policy Studies Journal, Vol. 30, No. 3 (2002): 379 - 395

Smith, Rogers, M., "Ideas, Institutions, and Strategic Choices," Polity, Vol. 28, No. 1 (1995): 135 140

Solberg, Kristin E., "New Laws Could Improve Women's Health in Pakistan," World Report, Vol. 375 (2010): 1956

Sorauf, Frank J., "The Public Interest Reconsidered," The Journal of Politics, Vol. 19, No. 4 (1957): pp. $616-639$

Sparrow, Malcolm K., The Regulatory Craft: Controlling Risks Solving Problems and Managing Compliance (Washington D.C.: The Brookings Institute, 2000)

Spiller, Pablo T., "Politicians, Interest Groups and Regulators: A Multiple-Principals Agency Theory of Regulation, or Let Them be Bribed," Journal of Law and Economics, Vol. 33, No. 1 (1990): pp. $65-101$

Stake, Robert E., "The Case Study Method in Social Inquiry," Educational Researcher, Vol. 7, No. 2 (1978): $5-8$

Stake, Robert E., The Art of Case Study Research (London: Sage, 1995)

Stake, Robert E., Qualitative Research: Studying How Things Work (New York: Guilford Press, 2010)

Steiner, Nils D., "Comparing Freedom House Democracy Scores to Alternative Indices and Testing for Political Bias: Are US Allies Rated as More Democratic by Freedom House?," Journal of Comparative Policy Analysis, (2014): 1 - 21

Steinberger, Peter J., "Typologies of Public Policy: Meaning Construction and the Policy Process," (pp. 27 - 39) in Irving Louis Horowitz (ed.) Policy Studies Review Annual, Vol. 5 (California: Sage, 1981)

Stewart, S. (ed.), Presidents, Oligarchs and Bureaucrats: Forms of Rule in the Post-Soviet Space (Surrey: Ashgate, 2012) 
Stewart, J., and Ayres, R., “The Public Policy Process,” (pp. 20 - 35) in Chris Aulich, John Halligan, Sandra Nutley (eds.) Australian Handbook of Public Sector Management (New South Wales: Allen \& Unwin, 2001)

Stewart, J., Hedge, David M. and Lester, James P., Public Policy: An Evolutionary Approach, 3rd ed. (Boston: Thomson Higher Education, 2008)

Sultan, S., "Evolution of Pediatric Urology at Sindh Institute of Urology and Transplantation (SIUT)," Frontier in Pediatrics, Vol. 2 (2014): Article 88

Smith, Kevin B. and Larimer, Christopher W., The Public Policy Theory Primer, 2nd ed. (Philadelphia: Westview Press, 2013)

Smith, Katherine, E. and Ketikireddi, Srinivasa V., "A Glossary of Theories for Understanding Policymaking," Journal of Epidemiology and Community Health, Vol. 67, No. 2 (2003): $198-202$

Sproule-Jones, M., "Multiple Rules and the 'Nesting' of Public Policies," Journal of Theoretical Politics, Vol. 1, No. 4 (1989): 459 - 477

Stigler, George J., "The Theory of Economic Regulation," The Bell Journal of Economics and Management Science, Vol. 2, No. 1 (1971): pp. 3 - 21

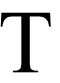

Talbot, I., "The Punjabization of Pakistan: Myth or Reality?” (pp. 51 - 84) in Christopher Jaffrelot (ed.) Pakistan: Nationalism without a Nation (London: Zed Books, 2002)

Tannenwald, N., "Ideas and Explanation: Advancing the Theoretical Agenda," Journal of Cold War, Vol. 7, No. 2 (2005): $13-42$

Tepper, Elliot L., "The New Pakistan: Problems and Prospects. Pacific Affairs, 47.1 (1974): 56 - 68

Teubner, G. (ed.) Autopoietic Law: An New Approach to Law and Society (Berlin: Walter de Gruyter, 1988)

The Dakar Framework for Action adopted in the World Education Forum held from April 26 - 28, 2000 in Dakar, Senegal (Paris: UNESCO, 2000)

The Fourth World Conference of Women, "Beijing Declaration and Platform for Action," held in Beijing from September 4 to 15, 1995

Thomas, Clive S. and Hrebenar, Ronald J., "Understanding Interest Groups, Lobbying and Lobbyists in Developing Democracies," Journal of Public Affairs, 8 (2008): 1 - 14

Tocqueville, Alexis de, Journey to America (1831-1832)—Alexis de Tocqueville's travel diary of his visit to America; [trans.] George Lawrence, [ed.] J. P. Mayer (New Haven, CT: Yale University Press, 1960)

Tollison, Robert D., "The Interest-Group Theory of Government: Problems and Prospects," KYKLOS, Vol. 54, No. 2/3 (2001): 465 - 472

Tollison, Robert D., "Public Choice and Antitrust," Cato Journal, Vol. 4, No. 3 (1985): 905 - 915

Torgerson, D., "Power and Insight in Policy Discourse: Post-positivism and Problem Definition," (pp. 266 - 298) in L. Dobuzinskis, M. Howlett and D. Laycock (eds.) Policy Studies in Canada: The State of the Art (Toronto, University of Toronto Press, 1996)

Torgerson, D., "Between Knowledge and Politics: Three Faces of Policy Analysis," Policy Sciences, Vol. 19 (1986): 33 - 59

Toye, J., "Interest Group Politics and the Implementation of Adjustment Policies in Sub-Saharan Africa," (pp. 106 - 126) in Peter Gibbon, Yusuf Bangura and Arve Ofstad (eds.) Authoritarianism, Democracy and Adjustment: The Politics of Economic Reform in Africa (Uppsala: Nordic Africa Institute, 1992)

Trebing, Harry M., "Regulation of Industry: An Institutionalist Approach," Journal of Economic Issues, Vol. 21, No. 4 (1987): 1707 - 1737

Truex, R., "The Myth of the Democratic Advantage," Studies in Comparative International Development, 2015, DOI 10.1007/s12116-015-9192-4

Tudor, M., The Promise of Power: The Origin of Democracy in Indian and Autocracy in Pakistan (Cambridge: Cambridge University Press, 2013) 
Annexures

Tullock, G., “A (Partial) Rehabilitation of the Public Interest,” Public Choice, Vol. 42, No. 1 (1984): $89-99$

Tullock, G., "The Fundamentals of Rent-Seeking," The Locke Luminary, Vol. 1, No. 2 (1998): Part 2

Tullock, G., "The Welfare Costs of Tariffs, Monopolies and Theft," Western Economic Journal, Vol. 5, No. 3 (1967): pp. $224-232$

\section{$\mathrm{U}$}

Ukey, Krishnarao L., "Devils at Workplace: Women Employees Beware," International Journal of Human Resource Management, Vol. 3 (2013): 6 - 17

Ullah, A., "Right to Free and Compulsory Education in Pakistan after $18^{\text {th }}$ Constitutional Amendment," South Asian Studies, Vol. 28, No. 2 (2013): 332

Ulvik, M., Protection from Sexual Harassment at the Workplace in the United States and What European Union Could Learn from it (Budapest: Central European University Electronic Thesis and Dissertation, 2008)

Ünay, S., "The Rise of the Regulatory State in Europe," Turkish Journal of Politics, Vol. 2, No. 1 (2011): $21-31$

UNICEF Annual Report 2012 for Pakistan, ROSA, 2013

UNICEF. All Children in Schools by 2015: Global Initiative on Out of School Children - Out of School Children in the Balochistan, Khyber Pakhtunkhwa, Punjab and Sindh Provinces of Pakistan (Islamabad: UNICEF Pakistan, 2013)

Valentine, E., "Pakistan Parliamentary Libraries: A Historical Excursion and Hopes for the Future," Library Trends, Vol. 58, No. 4 (2010): 527 - 547

Vedung, E. "Policy Instruments: Typologies and Theories," (pp. 21 - 58) in Marie-Louise Bemelmans-Videc, Ray C. Rist, Evert Vedung (eds.) Carrots, Sticks, \& Sermons: Policy Instruments and their Evaluation, $4^{\text {th }}$ paperback edition (New Jersey: Transaction Publishers, 2007)

Viscusi, W. K, Harrington, Joseph E. and Vernon, John M., Economics of Regulation and Antitrust (Cambridge, MA: MIT Press, 2005): pp. $375-378$

Viscusi, W. K., DeMuth, C., and Burnley, J., "Health and Safety Regulation," (pp. $453-518$ ) in Martin Feldstein (ed.) American Economic Policy in 1980s (Chicago: The University of Chicago Press, 1994)

Volkomer, W., American Government, 11th ed. (Upper Saddle River, NJ: Prentice Hall, 2011)

W

Warde, William F., “John Dewey's Theories of Education,” International Socialist Review Vol. 21, No. 1 (1960): $5-8$

Waheed, Ahmed W. and Abbasi, Javeria Y., "Rethinking Democracy in Pakistan," Asia Affairs, Vol. 44, No. 2 (2013): $202-214$

Waseem, M., "Judging Democracy in Pakistan: Conflict Between the Executive and Judiciary," Contemporary South Asia, Vol. 20, No. 1 (2012): 19 - 31

Waseem, M., "Pakistan: A Majority-Constraining Federalism," India Quarterly: A Journal of International Affairs, Vol. 67, No. 3 (2011): 213 - 228

Weisbrod, Burton A., "Conceptual Perspective on the Public Interest: An Economic Analysis," (pp. 4 - 29) in Burton A. Weisbrod, Joel F. Handler and Neil K. Komesar (eds.) Public Interest Law: An Economic and Institutional Analysis (Berkeley: University of California Press, 1978): 
Wentzel, J., An Imperative to Adjust: Skill Formation in England and Germany (Heidelberg: Springer, 2011)

Weyland, K., “Toward a New Theory of Institutional Change," World Politics, Vol. 60, No. 2 (2008): $281-314$

Wright, John S., and Head, B., "Reconsidering Regulation and Governance Theory: A Learning Approach," Law \& Policy, Vol. 31, No. 2 (2009): $192-216$

Wilson, James Q., Bureaucracy: What Government Agencies do and Why they do it (New York: Basic Books, 1989)

Watts, R., "Government and Modernity: An Essay in Thinking Governmentality," Arena Journal, Vol. 2 (1993/94): $103-157$

Y

Yandle, B. and Young, E. "Regulating the Function, Not the Industry," Public Choice, Vol. 51 (1986): pp. $59-70$

Yandle, B., "Bootleggers and Baptists - The Education of a Regulatory Economist," Regulation, Vol. 7, No. 3 (1983): $12-16$

Yandle, B., "Bootleggers and Baptists in the Theory of Regulation," (pp. 25 - 33) in David Levi-Faur (ed.) Handbook on the Politics of Regulation (Cheltenham: Edward Elgar, 2011)

Yasmeen, S. and Ali, W., "Role and Functions of Judicial System in Pakistan," Science, Technology and Development, Vol. 30, No. 3 (2011): 1 - 12

Yin, Robert K., Case Study Research: Design and Methods, (London: Sage Publications, 2003)

Yin, Robert K., Application of Case Study Research (London: Sage, 2012): 3 - 20

Yusuf, H. and Schoemaker, E., "The Media of Pakistan: Fostering Inclusion in a Fragile Democracy?" BBC Media Action Policy, Briefing 9, September 2013

Z

Zaka, Muhammad Rashid M., "Role of Women Parliamentarians and Research Practices in Pakistan," Journal of Peace, Conflict \& Development, Vol. 19 (2012): 20 - 31

Zilla, C., "Deliberative Democracy," in George Thomas Kurian (editor-in-chief) The Encyclopedia of Political Science (Washington, DC: QC Press, 2011): 385

Zippel, Kathrin S., The Politics of Sexual Harassment: A Comparative Study of the United States, the European Union, and Germany (Cambridge: Cambridge University Press, 2006)

Ziring, L., Pakistan: At the Crosscurrent of History (Oxford: Oneworld Publications, 2003)

Zucker, Lynne G., "Institutional Theory of Organization," Annual Review of Sociology, Vo. 13 (1987): $443-464$ 



\section{CURRICULUM VITAE}

Address: Plot 23 (BIAFO Building), Street 39, I. \& T. Center, G-10/4, Islamabad 44000 Pakistan Cell: +92 (0) $300-8411327$ / Home: +92 (0) $51-2375028$ atif.ikram@gmail.com http://sites.google.com/site/atifikram

\section{PROFESSIONAL EXPERIENCE}

\begin{tabular}{lll}
\hline Apr 15 to date & Executive Director & Center for Communication Programs Pakistan \\
\hline May 11-Mar 15 & $\begin{array}{l}\text { Lead C4D - Child } \\
\text { Protection }\end{array}$ & $\begin{array}{l}\text { United Nations Children's Fund (UNICEF) } \\
\text { Child Protection Section, Islamabad - Pakistan }\end{array}$ \\
\hline Mar 08-May 11 & $\begin{array}{l}\text { Director } \\
\text { Communication }\end{array}$ & $\begin{array}{l}\text { Johns Hopkins University (JHU) } \\
\text { Center for Communication Programs, Islamabad }\end{array}$ \\
\hline Aug 07-Feb 08 & Research Specialist & $\begin{array}{l}\text { United Nations Development Programme (UNDP) } \\
\text { National Reconstruction Bureau (NRB), Islamabad }\end{array}$ \\
\hline Dec 04-Apr 07 & $\begin{array}{l}\text { During this period, I completed my second Master degree in public policy from the } \\
\text { Willy Brandt School of Public Policy, and a yearlong fellowship in leadership form } \\
\text { the East-West Center, University of Hawaii, US }\end{array}$ \\
\hline
\end{tabular}

Aug 03-Dec 04 Project Officer International Labour Organization (ILO)

International Program on the Elimination of Child Labour

\begin{tabular}{lll}
\hline Apr 01-Jul 03 & Executive Officer & $\begin{array}{l}\text { Population Association of Pakistan (PAP) } \\
\text { Population Council, Islamabad }\end{array}$
\end{tabular}

Jan 00-Dec $00 \quad$ Project Officer $\quad$ German Agency for International Cooperation (GIZ)

Health Services Academy, Islamabad

Feb 99-Dec 99 Project Assistant $\quad$ Department for International Development (DFID)

British Council, Lahore - Pakistan

\begin{tabular}{lll} 
ACADEMIC QUALIFICATION & \\
\hline $2011-2016$ & $\begin{array}{l}\text { PhD International } \\
\text { Dev. Studies }\end{array}$ & $\begin{array}{l}\text { Institute of Development Research and Development } \\
\text { Policy, Ruhr-Universität Bochum, Germany }\end{array}$ \\
\hline $2006-2007$ & Leadership Fellow & $\begin{array}{l}\text { Asia-Pacific Leadership Program, University of } \\
\text { Hawaii, United States }\end{array}$ \\
\hline $2004-2006$ & $\begin{array}{l}\text { Master of Public } \\
\text { Policy }\end{array}$ & $\begin{array}{l}\text { Willy Brandt School of Public Policy } \\
\text { Universität Erfurt, Germany }\end{array}$ \\
\hline $1999-2001$ & $\begin{array}{l}\text { Master of Business } \\
\text { Administration }\end{array}$ & $\begin{array}{l}\text { Hamdard Institute of Management Sciences } \\
\text { Hamdard University, Pakistan }\end{array}$ \\
\hline $1997-1998$ & PGD in MIS & $\begin{array}{l}\text { Federal Postgraduate Medical Institute } \\
\text { Lahore, Pakistan }\end{array}$ \\
\hline $1995-1997$ & Bachelor of Science & University of the Punjab (PU), Lahore, Pakistan \\
\hline
\end{tabular}




\section{VOLUNTEER PROFESSIONAL AFFILIATIONS}

- Media Coordinator of the East-West Center-USA Pakistan Chapter;

- Member of the International Public Policy Association;

- Founding Member of Center for Communication Programs Pakistan, Johns Hopkins University's sister organization;

- Lifetime Member of the Population Association of Pakistan.

\section{AWARDS / FELLOWSHIPS}

- 2016 - New Generation of Family Planning and Reproductive Health Leadership Award

- 2011/2014 - Doctoral Fellow, Heinrich-Böll-Stiftung, Ruhr University Bochum, Germany

- 2011/2012 - Research Fellow, DAAD Re-invitation Programme, University of Erfurt, Germany

- 2006/2007 - Leadership Fellow, East-West Center, United States

- 2005/2006 - Graduate Fellowship Award, Heinrich-Böll-Stiftung, University of Erfurt, Germany

- 2004/2005 - DAAD Graduate Fellowship Award, University of Erfurt, Germany

- 1999/2001 - Dean's Merit List Award (twice), Hamdard University, Pakistan

- 1997/1998 - Student of the Year Award, Federal Postgraduate Medical Institute, Pakistan

\section{LANGUAGE \& COMPUTER SKILLS}

- Fluent in English, Urdu, Punjabi and basic knowledge of German language;

- Well versed with MS-office word processing, spread sheet and presentation tools;

- Fairly expert in office automations software skills in MS Project; and

- Professional knowledge in data analysis in SPSS and MS-Access

\section{LIST OF PUBLICATIONS}

- 2014. "A Theoretical Framework for Engaging with Religion in Development Projects," Journal of Developing Societies, 30(3): 323 - 341

- 2013. "Magnesium Sulphate for Prevention and Treatment of Preeclampsia and Eclampsia in Pakistan: Review Article," Journal of the Society of Obstetricians and Gynaecologists of Pakistan, 3(2): 107-119

- 2010. Ulama: Agents of Social Change - Muslim Scholars Speak for Mothers Rights. Islamabad. Johns Hopkins Bloomberg School of Public Health.

- 2006. "Sexual Behaviour among Male Students in Islamabad, Pakistan: Is it a Matter of Concern?" In Sharing Population and Development Research across South and West Asia, 666-678. Islamabad: Population Association of Pakistan.

- 2005. "What is the Female Labour Force Participation Rate in Pakistan?" In Population Research and Policy Development in Pakistan, 509-547. Islamabad: Population Ass of Pak.

- 2004. "Determinants of Youth Development in Pakistan." Lahore Journal of Economic, 9(2): $119-133$

- 2004. "Shifting Paradigms and Emerging Trends in Employment among Urban Pakistani Women." Pakistan Journal of Women's Studies, 12(2): 29-57

- 2003. "Women in New Professions: The Case of Urban Pakistan," In Population and Sustainable Development in Pakistan, 165-192. Islamabad: Population Ass of Pakistan. 